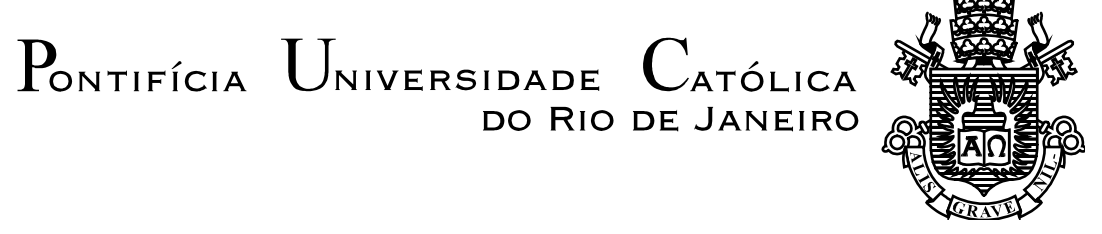

Fátima Marinho Fabrício Monteiro

\begin{abstract}
RITUAIS APÓS A MORTE
Aspectos interculturais envolvendo Brasil,

Canadá e Noruega
\end{abstract}

Dissertação de Mestrado

Dissertação apresentada ao Programa de PósGraduação em Estudos da Linguagem da PUC-Rio como requisito parcial para obtenção do título de Mestre em Letras/Estudos da Linguagem.

Orientadora: Profa. Rosa Marina de Brito Meyer Coorientador: Prof. Ricardo Borges Alencar 


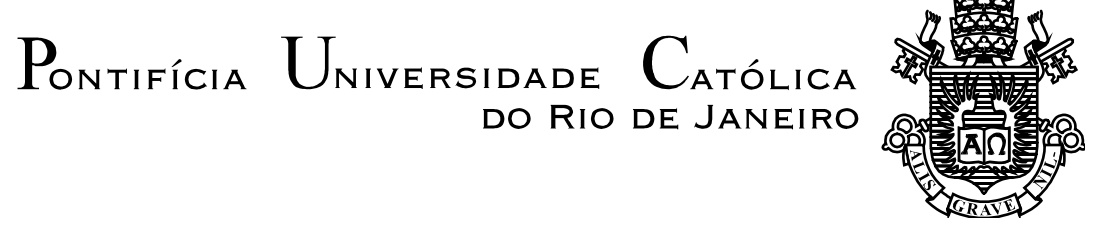

Fátima Marinho Fabrício Monteiro

RITUAIS APÓS A MORTE

Aspectos interculturais envolvendo Brasil,

Canadá e Noruega

Dissertação apresentada como requisito parcial para obtenção do grau de Mestre pelo Programa de Pós-Graduação em Estudos da Linguagem da PUC-Rio. Aprovada pela Comissão Examinadora abaixo assinada.

\author{
Profa. Rosa Marina de Brito Meyer \\ Orientadora \\ Departamento de Letras - PUC-Rio
}

Prof. Ricardo Borges Alencar

Coorientador

Departamento de Letras - PUC-Rio

Profa. Adriana Ferreira de Sousa de Albuquerque

Departamento de Letras - PUC-Rio

Prof. José Carlos Santos de Azeredo

Instituto de Letras - UERJ

Profa. Denise Berruezo Portinari Coordenadora Setorial do Centro de Teologia e Ciências Humanas - PUC-Rio

Rio de Janeiro, 01 de setembro de 2015 
Todos os direitos reservados. É proibida a reprodução total ou parcial do trabalho sem autorização da universidade, da autora e da orientadora.

\section{Fátima Marinho Fabrício Monteiro}

Graduou-se em Letras pela UERJ em 1978. Especializou-se em Português para Estrangeiro pela UFRJ em 1988. Lecionou Português para estrangeiros (níveis médio e avançado) em 1988 na UFRJ, e Português como língua materna no Ensino Fundamental II e Médio no Colégio Santa Marcelina, e na Rede Municipal de Ensino. Foi coordenadora de Português no Colégio Santa Marcelina. Ministrou curso de Português Instrumental na Shell (Rio e São Paulo), na Petrobras (Rio) e no INPE (São Paulo). Apresentou comunicação com publicação de trabalho no III SIMELP em Macau (2011), na VIII ALSFAL em Montevidéu (2012) e na IX ABRALIN em Belém (2015) entre outros. Hoje, leciona na Rede Estadual de Ensino-RJ e faz parte da Banca de correção do Vestibular da UERJ.

Ficha Catalográfica

Monteiro, Fátima Marinho Fabrício

Rituais após a morte: aspectos interculturais envolvendo Brasil, Canadá e Noruega / Fátima Marinho Fabrício Monteiro; orientadora: Rosa Marina de Brito Meyer; coorientador: Ricardo Borges Alencar - 2015.

210 f.: il. (color.) ; $30 \mathrm{~cm}$

Dissertação (mestrado) - Pontifícia Universidade Católica do Rio de Janeiro, Departamento de Letras, 2015.

Inclui bibliografia

1. Letras - Teses. 2. Português para estrangeiros. 3. interculturalismo. 4. ritual de passagem funeral. 5. espaço ambíguo. 6. linguagens verbal e não verbal específicas. I. Meyer, Rosa Marina de Brito. II. Alencar, Ricardo Borges. III. Pontifícia Universidade Católica do Rio de Janeiro. Departamento de Letras. IV. Título. 


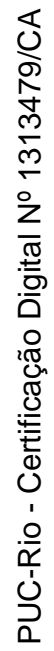

Para os meus filhos, Hugo e Thiago, com imenso amor e admiração. 


\section{Agradecimentos}

A Deus, por habitar em mim, fortalecendo e iluminando-me em todos os momentos de minha vida.

À minha orientadora Prof ${ }^{a}$ Rosa Marina de Brito Meyer, que, com sabedoria, firmeza e carinho, enriqueceu esta pesquisa com seus ajustes preciosos.

Ao meu coorientador, Prof. Ricardo Borges Alencar, pelo entusiasmo, sugestões e parceria durante a caminhada.

À CAPES e à PUC-Rio, pela bolsa de isenção concedida.

A todos os mestres que lançaram luz às minhas ideias durante esta eterna trajetória de aprendizagem. Com eles, como no poema de Drummond, "Aprendi novas palavras / E tornei outras mais belas".

A meus pais, na esfera do "outro mundo", pelo amor incondicional e por terem-me cuidado como um bem maior de suas vidas.

À minha família e aos amigos queridos que contribuíram para a realização desta pesquisa e partilharam do trajeto de conquista com observações sempre oportunas.

Aos funcionários da secretaria de Pós-Graduação do Departamento de Letras da PUC-Rio, em especial, à Francisca F. de Oliveira, nossa Chiquinha, que, atendendo o público com delicadeza e carinho, faz com que alunos, professores e visitantes sintam-se contemplados e protegidos.

Aos caríssimos informantes, que me forneceram novas lentes para o enriquecimento de minha competência intercultural, um agradecimento especial pela valiosíssima contribuição na coleta dos dados, sem os quais esta pesquisa não teria sido viabilizada.

Aos docentes membros da banca examinadora, pela gentileza de terem aceitado o nosso convite.

A todos, meu cordial abraço! 


\section{Resumo}

Monteiro, Fátima Marinho Fabrício; Meyer, Rosa Marina de Brito. Rituais após a morte: aspectos interculturais envolvendo Brasil, Canadá e Noruega. Rio de Janeiro, 2015. 210 p. Dissertação de Mestrado Departamento de Letras, Pontifícia Universidade Católica do Rio de Janeiro.

Nesta análise comparativa, revelam-se comportamentos, sentimentos, celebrações e o como se expressam os falantes nativos no que se refere ao ritual de passagem morte, no Brasil, Canadá e Noruega, considerando-se o uso da linguagem humana, verbal e não verbal, como veículo de expressão de valores culturais e hábitos comportamentais, e de exteriorização de sentimentos pessoais. O corpus foi coletado de duas séries de entrevista online realizadas com informantes nascidos nesses países, testemunhas desses ritos. A fundamentação teórica básica deste trabalho concentra-se na área do Interculturalismo, aliada à área da Linguística. Os principais autores que nortearam a investigação foram Lewis (2006), DaMatta (2004; 1997; 1993; 1987; 1984), Tagnin (2013; 1989) e Perini (2010; 2003; 1999). Nossos resultados revelam, entre outros achados, que os rituais observados corroboram a classificação de Lewis (2006) quanto aos países multiculturais, enquanto aqueles classificados como de cultura ativo-linear sofrem algumas variações regionais, aproximando-se por vezes da categoria de cultura multiativa.

\section{Palavras-chave}

Português para estrangeiros; interculturalismo; ritual de passagem funeral; espaço ambíguo; linguagens verbal e não verbal específicas. 


\section{Abstract}

Monteiro, Fátima Marinho Fabricio; Meyer, Rosa Marina de Brito (Advisor). Rituals after death: intercultural aspects involving Brazil, Canada and Norway. Rio de Janeiro, 2015. 210 p. MSc. Dissertation Departamento de Letras, Pontifícia Universidade Católica do Rio de Janeiro.

This comparative analysis, reveals behaviors, feelings, celebrations and how they are expressed in relation to the rite of death passage in Brazil, Canada and Norway, considering the use of human language, verbal and non-verbal, as a vehicle for expressing cultural values, behavioral habits as well as personal feelings externalization. The corpus has been collected from two online interview series conducted with native speakers of these countries who have already witnessed such rites. The basic theoretical foundation of this research focuses on the area of Interculturalism along with the area of Linguistics. The main authors who have guided this research are Lewis (2006), Da Matta (2004; 1997; 1993; 1987; 1984), Tagnin $(2013 ; 1989)$ and Perini $(2010 ; 2003 ; 1999)$. Our results reveal, among other findings, that the multicultural countries under analysis, categorized by Lewis as linear-active culture places, suffer some regional variations, approaching the multi-active culture category.

\section{Keywords}

Portuguese for foreigners; interculturalism; rite of passage funeral; ambiguous space; specific verbal and nonverbal languages. 


\section{Sumário}

1. Introdução 12

1.1. Tema e Contextualização 12

1.2. Relevância 14

1.3. Hipóteses 15

1.4. Objetivos 15

1.5. Organização do Trabalho 16

2. Aporte Teórico 17

2.1. Aspectos Culturais e Interculturais 17

2.1.1. Roque Laraia 18

2.1.2. Contribuições de Edward T. Hall 19

2.1.3. Richard D. Lewis 21

2.1.3.1. Categorização de Culturas 21

2.1.3.2. Identidades Nacionais 23

2.1.3.2.1. Brasil 24

2.1.3.2.2. Canadá 28

2.1.3.2.3. Noruega 32

2.1.4. Roberto DaMatta 35

2.1.4.1. Espaços Sociais, Morais ou Éticos 35

2.1.4.1.1. A Casa e a Rua 35

2.1.4.1.2. Espaço Ambíguo 37

2.1.4.1.3. Esfera do Outro Mundo 38

2.1.4.2. Rituais de Passagem 39

2.2. Aspectos Linguísticos 40

2.2.1. Stella Esther Ortweiler Tagnin 41

2.2.1.1. Unidades Linguísticas Convencionais 41

2.2.1.2. A Convencionalidade 41

2.2.1.3. Expressões Convencionais 43

2.2.1.4. Níveis da Convencionalidade 43

2.2.1.5. Expressões Idiomáticas 46

2.2.2. Mário Alberto Perini $\quad 47$

2.2.2.1. Relevância das Expressões Idiomáticas na Descrição 49 
3. Metodologia 51

3.1. O Método da Pesquisa 52

3.2. O Método da Análise 57

4. Análise 59

4.1. Aspectos Culturais 59

4.1.1. Contextos e Significados 61

4.1.2. Espaços Ambíguos 72

4.1.3. A Esfera do Outro Mundo 76

4.1.4. Rituais de Passagem 78

4.2. Convencionalidade e Linguagem 83

4.2.1. Expressões Verbais 84

4.2.1.1. Expressões Convencionais 85

4.2.1.2. Expressões Idiomáticas 90

4.2.2. Suavização, Afrontamento, Realidade 95

4.2.3. Linguagem Não Verbal 96

4.3. Outros Achados Linguísticos 100

4.4. Outros Achados Iconográficos 140

5. Conclusão 144

6. Referências Bibliográficas 150

7. Sites Web Apresentados 153

8. Anexos 154

8.1. Anexos A 154

8.2. Anexos B 203

9. Apêndices 205 


\section{Lista de llustrações}

1. Figura 1- Tipos de culturas: esquema de Lewis (2006: 41) 23

2. Figura 2- Tagnin $(2013,27)$ - Esquema resumitivo adaptado 44

3. Quadro 1-Metodologia da pesquisa 53

4. Quadro 2- Visualização de informantes por gênero 57

5. Quadro 3- Contextos e significados 62

6. Figura 3- Fac-símile - jornal O Globo - 16/05/2015 77

7. Quadro 4- Expressões convencionais A 85

8. Quadro 5- Expressões convencionais B 88

9. Quadro 6- Expressões idiomáticas 90

10. Quadro 7- Palavras de sentido conotativo 95

11. Figura 4- Imagem WhatsApp 100

12. Quadro 8- Compilação de respostas - dados canadenses 101

13. Quadro 9- Compilação de respostas - dados noruegueses 108

14. Quadro 10- Compilação de respostas - dados brasileiros no Canadá

15. Quadro 11 - Compilação de respostas - dados brasileiros na Noruega

16. Quadro 12- Compilação de respostas - dados brasileiros no Brasil

17. Figura 5- Velório do cantor Wando 141

18. Figura 6- Funeral em igreja católica no Canadá 141

19. Figura 7- Velório de não religioso na Noruega 142

20. Figura 8- Funeral do piloto de Fórmula I Ayrton Senna 143

21. Quadro 13- Segunda etapa das entrevistas 206

21. Quadro 14- Dados dos informantes 208

22. Quadro 15- Linguagens verbal e não verbal específicas 209 


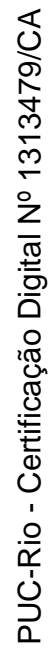

"O mundo é mágico. As pessoas não morrem, ficam encantadas."

(Guimarães Rosa) 


\section{Introdução}

Como se aprende com Azeredo (2009: 58), “conhecer uma língua é, necessariamente, saber servir-se dela, compreendê-la e vivenciá-la como expressão da vida em sociedade, com sua diversidade, sua complexidade, suas convenções, seus ritos, suas crenças, seus valores". Por isso, uma vez que a comunicação ultrapassa o limite do verbal, apesar de esta pesquisa ter um foco primordialmente linguístico, aspectos interculturais e não verbais serão levados em consideração na análise dos dados. Assim, elementos comunicativos como a expressão facial, o olhar, o sorriso e as lágrimas serão considerados por também dizerem, e muito.

\subsection{Tema e Contextualização}

Desenvolvendo a pesquisa no âmbito do interculturalismo, esta dissertação tem como tema os contornos culturais particulares que se inferem das linguagens, dos comportamentos e dos ritos observados numa situação social específica, qual seja, os funerais e velórios - a partir das semelhanças e diferenças entre três países: o Brasil, o Canadá e a Noruega.

Este recorte do tema partiu de uma conversa com a pesquisadora canadense Dra. Olenka Bilash, da Universidade de Alberta (CA), então, ministrando uma disciplina como Professora Visitante na PUC-Rio. Nessa conversa, ficou patente o choque intercultural sofrido por ela quando estava no Rio de Janeiro e se viu imersa em uma situação social que pôs em relevo valores e hábitos internalizados, refletindo características de sua cultura por oposição àquela da sociedade em que se encontrava. A seguir, passamos a apresentar uma breve descrição do evento que motivou esta pesquisa.

No primeiro semestre de 2014, inscrevemo-nos na disciplina optativa Intercultural Competence and Second Language Aquisition, ministrada pela Professora Olenka Bilash, em inglês, no Programa de Pós-Graduação em Estudos da Linguagem da PUC-Rio (PPGEL). A partir de leituras de textos de Lewis (2006), Peterson (2004), Hofstede (2012), Bennett (1998), Marshall Singer 
(1998), Adrian Holliday (2011), James Lantolf (2000), entre outros, a Professora Bilash conduziu as aulas de forma a refletirmos sobre conceitos como cultura, interculturalismo, competência intercultural, diversidade cultural, aquisição de uma segunda língua e, consequentemente, de uma segunda cultura. $\mathrm{O}$ curso foi intensivo e intenso. Muito enriquecedor.

Certo dia, a turma recebeu um e-mail, enviado por Bilash, com o desabafo de um choque intercultural que tinha sofrido por ocasião do falecimento do chefe da família com a qual residia. Em uma longa mensagem, ela falava de sua tristeza e do desconforto diante daquela experiência intercultural. Como a pesquisadora não sabia quais eram os protocolos para funerais em nosso país e não tinha com quem se informar, sem saber o que esperar, foi até a PUC-Rio pedir algumas orientações. Então, ela soube que havia uma loja de flores em frente ao cemitério, que seria conveniente vestir preto e chegar ao funeral meia hora antes do sepultamento. Quando perguntou em que dia seria a "visão do corpo", ficou muito surpresa por saber da rapidez com que tudo acontece em nosso país. Além disso, no funeral, passou por outras situações incômodas. Por exemplo, as flores que havia comprado não foram entregues por ela, como esperava; os discursos para o falecido foram poucos, muito curtos e seguidos de aplausos; todos os presentes seguiram o caixão a pé e assistiram ao sepultamento; algumas flores foram jogadas na sepultura antes de a urna ser baixada, e as restantes foram depositadas sobre o túmulo. A professora não esperava passar por essa experiência no Brasil, e os estranhamentos foram tantos que deixaram nela marcas mais profundas do que o que se entenderia usualmente por um "mero" choque cultural. Com o acontecimento, Bilash disse ter aprendido duas coisas: primeiro, que saudade é uma palavra que aparece nas lápides no Brasil; segundo, que, quando se vai para um lugar por muitos meses, ter um vestido preto é essencial. Terminou o e-mail agradecendo-nos por "ouvi-la" e dizendo que sentia falta de todos nós.

O caso despertou nosso interesse, pois a morte pode acontecer a qualquer instante, e não basta ter um "pretinho básico" na bagagem para se entenderem as convenções da sociedade local. Quando nos encontramos, falando sobre o ocorrido, ela, com empolgação, disse-nos que o assunto era bem interessante e pertinente para uma dissertação, prontificando-se a colaborar. Poderíamos pesquisar para estabelecer comparações entre Brasil e Canadá, países que, nesse 
primeiro momento, suscitaram as questões referentes ao choque intercultural naquela situação narrada.

A adição de um terceiro país surgiu porque, na ocasião, soubemos que, na Noruega, semelhantemente ao Canadá, os funerais ocorrem a partir de sete dias do falecimento, e, também, achamos interessante aplicar a teoria triangular e escalar de Lewis, que vínhamos estudando, em que ele situa todos os países do mundo numa categoria de identidade nacional (Cf. 2.1.3.1).

Por isso, fizemos a opção por uma pesquisa no âmbito do interculturalismo, que observasse as linguagens, os comportamentos e os ritos presentes nas situações sociais velório e funeral de forma que permitisse triangularmos os contornos particulares das culturas nacionais em foco.

\subsection{Relevância}

Admitindo que, no âmbito do interculturalismo, temas que versam sobre a morte são pouco explorados, e que os brasileiros, em geral, não falam sobre eles no dia a dia, evitando, inclusive, abordar o assunto, as informações colhidas na pesquisa fornecem elementos da realidade desse ritual de passagem. Assim sendo, esses dados são as chaves interpretativas desse fato social nesta investigação e poderão enriquecer futuros estudos sobre o assunto. Por isso, diante da escassez de literatura relativa ao tema apontado, fica clara a relevância desta dissertação linguístico-antropológica que descreve o cenário dos rituais de passagem pósmorte em algumas regiões dos três países aqui mencionados. Essas nações apresentam pontos culturais que ora se aproximam, ora se afastam, os quais devem ser divulgados para que possa haver uma competência intercultural entre interactantes do Brasil, Canadá e Noruega, caso se deparem com contexto de interação em funerais no país do outro.

Consequentemente, também, a relevância de uma investigação antropológica aliada à linguística - posto que os valores socioculturais sempre se traduzem em alguma forma de linguagem - a fim de possibilitar a identificação, observação, pesquisa e análise de aspectos interculturais e linguísticos; e para que se possam prevenir os padrões de comportamento de uma cultura, o entendimento do modo como pessoas de outras culturas agem, o resguardo de ofensas, a procura por determinado tipo de unidade na diversidade e a percepção de nitidez e ordem nos 
eventos sociais. Desse modo, podem-se evitar dificuldades nas interações, tais como desentendimentos, impasses, intolerâncias, julgamentos e choques interculturais.

\subsection{Hipóteses}

Considerando o Brasil, o Canadá e a Noruega, o conceito de identidade nacional de Lewis (2006) (Cf. 2.1.3.1), de casa e rua de DaMatta (2013) (Cf. 2.1.4.1.1) e o choque intercultural por que passou a pesquisadora Bilash, o qual foi a motivação para a pesquisa, trabalhamos com três hipóteses.

Primeira, as pessoas de uma determinada identidade cultural, quando estão fora de seu país e não conhecem a cultura-alvo, podem passar por um choque intercultural, ou, sem perceber, cometer alguma gafe ao terem que participar de um funeral.

Segunda, em funerais, apenas pessoas de países de cultura multiativa, como os brasileiros, expressam seus sentimentos em público e se cumprimentam com abraços e beijos, usando palavras e expressões de conotação suave para comunicar a morte.

Terceira, considerando situações relativas aos rituais de passagem funeral, somete no Brasil os espaços sociais apresentam-se ambíguos (Cf. 2.1.4.1.2).

\subsection{Objetivos}

Para efeito de estudo acadêmico, esta pesquisa pretendeu:

\section{A. Objetivo Geral}

Apresentar a linguagem humana, verbal e não verbal, como veículo de expressão de valores culturais e hábitos comportamentais, e de exteriorização de sentimentos pessoais, no que se refere aos rituais funerais. 


\section{B. Objetivos Específicos}

$\rightarrow$ identificar os comportamentos, a expressão de sentimentos, as formas de celebração e o como se expressar no que se refere ao ritual de passagem morte em três países de perfis culturais distintos;

$\rightarrow$ listar algumas das expressões convencionais usadas em rituais pós-morte, nesses três países, no funcionamento da língua de modo corrente e real, como instrumentos culturais e sociais de comunicação e interação;

$\rightarrow$ analisar algumas dessas expressões e palavras de usos expressivos;

$\rightarrow$ contribuir para a reflexão sobre a importância da competência intercultural na comunicação entre interactantes de regiões diferentes.

\subsection{Organização do Trabalho}

O presente trabalho é composto por cinco capítulos. Neste primeiro, são apresentadas as informações inicias para situar o leitor; entre elas, as hipóteses que serão retomadas nas considerações finais, confirmadas, ou não.

O segundo capítulo trata dos aspectos teóricos, apresentando os autores e descrevendo seus conceitos que lançaram luz sobre nossas reflexões para que houvesse uma perfeita interação entre teoria e prática na investigação e interpretação que foi feita dos dados, com foco nos aspectos interculturais e linguísticos.

O terceiro capítulo é o da metodologia. Nele aparece o método empregado para o levantamento das informações, o da Pesquisa Qualitativa; todo o processo de coleta de dados é descrito, assim como os desafios enfrentados para se conseguir o número de informantes necessários para atingir a meta estabelecida inicialmente, conforme descrita no método.

O quarto capítulo trata das análises interculturais e linguísticas do corpus, e apresenta outros achados decorrentes da riqueza das informações levantadas na pesquisa. Também, nesse capítulo, verifica-se a pertinência da aplicabilidade das teorias em foco a esses dados. A título de ilustração, expõem-se algumas imagens.

O quinto capítulo apresenta as considerações finais. Ali se discute em que medida as hipóteses foram comprovadas, ou não, e se encaminham sugestões de estudos complementares. 


\section{Aporte Teórico}

Em cada uma das intensas leituras - em que ora havia o distanciamento crítico, ora o envolvimento consciente - realizadas durante o mestrado, muitos autores iluminaram-me as ideias e fomentaram minhas reflexões, também alimentadas pelos professores Adriana Albuquerque, Adriana Nóbrega, Érica Rodrigues, Helena Martins, Letícia Corrêa, Margarida Basílio, Maria Paula Frota, Olenka Bilash, Ricardo Alencar e Rosa Marina Meyer nas aulas e em encontros que tivemos. Este trabalho traz, portanto, essas vozes: de algum modo, todas se fazem aqui presentes, uma vez que, no dizer de Bakhtin (2003: 300), todo enunciado se compõe de "atitudes responsivas diretas e ressonâncias dialógicas".

Nesta pesquisa, norteiam nossas colocações Roque Laraia (2003), na definição de cultura; Edward T. Hall (1990; 1989; 2011), com os conceitos de cultura de alto contexto e de baixo contexto, com as categorias de tempo e de espaço e com a concepção de comunicação não verbal; Richard Lewis (2006), com o conceito de identidade cultural ou identidade nacional e as categorias tempo e espaço; Roberto DaMatta $(2004 ; 1997 ; 1993 ; 1987 ; 1984)$, com os conceitos de espaços sociais, e de ritual de passagem; Tagnin $(2013 ; 1989)$, com o conceito de convencionalidade da linguagem verbal e não verbal; Perini (2010;2003;1999), com as expressões idiomáticas; e Azeredo (2008), com os usos expressivos da língua.

Conforme o mencionado, cada um dos diferentes autores, em sua seara de atuação, contribuiu para que formássemos juízo sobre o tema. Entretanto, é dado especial destaque a Lewis e DaMatta, pois aspectos de seus trabalhos falam diretamente à pesquisa; e a Tagnin e a Perini, que servem de fio condutor à reflexão linguística aqui proposta. Vale destacar que outros autores serão referidos à medida que forem enriquecendo a escrita deste texto.

\subsection{Aspectos Culturais e Interculturais}

Para que haja uma real interação entre interlocutores de regiões ou países diferentes, além das questões estritamente linguísticas, conhecer a cultura de nosso interactante é de suma importância. Contudo, antes de mais nada, a pessoa tem que ter consciência da própria cultura e, depois, tomar consciência da cultura 
do falante da língua-alvo, ou seja, é preciso que os interlocutores tenham uma consciência intercultural; o que equivale ao conceito de Lewis (2006: 37) de competência intercultural, que, no dizer do pesquisador, é a capacidade de o indivíduo aprender, adaptar-se e ajustar-se ao estilo de comunicação de determinado contexto.

Mas, o que se entende por cultura? Sabe-se que há uma longa lista de definições, indo de acepções mais populares a descrições acadêmicas mais sofisticadas. Dentre tantos conceitos existentes, esta pesquisa opta por uma caracterização de cultura relevante para o que mais importa aqui, isto é, sua relação com a linguagem. Nesse sentido, a escolha recai sobre Laraia (2003), conforme explanações no item a seguir.

\subsubsection{Roque Laraia}

No que se refere ao conceito de cultura, o antropólogo social Roque Laraia (2003: 30-51) sintetiza um arcabouço teórico elaborado por pensadores e pesquisadores do campo da antropologia ao longo dos séculos, comentando que esse conceito tem passado por uma série de reconstruções. E, citando Murdock (1932), ele conclui: "Os antropólogos sabem o que é cultura, mas divergem na maneira de exteriorizar este conhecimento" (LARAIA, 2003: 51).

Mais adiante, citando a antropóloga Ruth Benedict (1972), ele defende a ideia de que "a cultura é como uma lente através da qual o homem vê o mundo" (LARAIA, 2003: 67). Apoiado nesse pensamento, o autor considera o etnocentrismo um fenômeno universal e destaca que:

O modo de ver o mundo, as apreciações de ordem moral e valorativa, os diferentes comportamentos sociais e mesmo as posturas corporais são assim produtos de uma lembrança cultural, ou seja, resultado da operação de uma determinada cultura (LARAIA, 2003: 68).

$\mathrm{Na}$ sequência da página, ele afirma entender, a partir das questões destacadas, o fato de indivíduos de culturas distintas poderem ser identificados com facilidade não só pela evidência das diferenças linguísticas, mas também pela maneira de agir, vestir-se, caminhar, comer, enfim, de comportar-se socialmente.

Podemos comprovar a relevância da escolha do conceito de Laraia com as palavras de um linguista que defende não ser a linguagem mero meio de comunicação, mas, principalmente, uma forma "de conhecimento do mundo como 
significação e de expressão de valores culturais e hábitos comportamentais intrínsecos à respectiva sociedade" (AZEREDO, 2008: 56).

Quanto ao interculturalismo, segundo a pesquisadora Meyer (2013), essa corrente teórico-metodológica surgiu a partir das dificuldades sentidas em dois campos profissionais: o da Educação e o dos Negócios. No que se refere à Educação, teve origem simultaneamente na Europa e nos Estados Unidos da América, embora sem ligação direta entre os continentes. Em cada um desses lugares, crianças respectivamente migrantes e imigrantes tiveram as mesmas dificuldades de aprendizagem devido ao não domínio da nova língua-alvo. Assim, surgiu a hipótese de que, além do ensino "estritamente linguístico, verbal e gramatical", o investimento em questões relacionadas a diferenças culturais poderia solucionar a situação. Ao mesmo tempo que a Educação passava por esse problema, executivos de organizações multinacionais e transnacionais de países industrializados tiveram grandes perdas de lucro e fracassaram em seus negócios por causa de desentendimentos, impasses, intolerâncias e julgamentos, nas transações com os países-alvo (MEYER, 2013: 13-15).

$\mathrm{Na}$ sequência da página, a linguista destaca que autores como Edward T. Hall, Geert Hofstede, Richard D. Lewis e Peterson passaram a analisar o fenômeno da globalização, na busca de ajuda para as finanças institucionais, pautados em propostas teórico-metodológicas bem definidas, publicando obras consideradas pilares do interculturalismo, bastante abrangentes e atuais, e apresentando parâmetros e categorias para o entendimento das diferentes culturas do mundo.

Conforme será mostrado na análise, há pontos de contato entre conceitos de Hall, Lewis e DaMatta. Sendo assim, admitindo que o primeiro pode corroborar ideias dos dois que norteiam esta pesquisa, na busca de traços característicos das culturas brasileira, canadense e norueguesa, passam-se a descrever conceitos de Hall básicos para uma pesquisa interculturalista.

\subsubsection{Contribuições de Edward T. Hall}

Em Contribuições de Edward T. Hall para amigos do AFS, (2011: 1), o antropólogo cultural, um dos precursores da teoria interculturalista, vê o conceito 
de cultura como um sistema de padrões que são aprendidos e analisáveis, aplicando esta noção à maneira como nos comunicamos.

Segundo a página da AFS (2011), considerando que contexto e significado estão relacionados, Hall cria os conceitos de alto contexto e baixo contexto, também traduzidos por indiretividade e diretividade respectivamente, baseando-se no modo como as pessoas interpretam ou apenas introjetam uma informação em determinada interação ou evento. O quanto de informação verbal é necessário em cada cultura para que a interação se realize de forma completa e eficiente?

Para o autor, a comunicação é de alto contexto quando a maior parte dela é entendida por meio do contexto físico e social. Assim, culturas de alto contexto, além de responderem verbalmente, usam todos os meios de interação. Encontrase, tipicamente, esse tipo de cultura no Oriente Médio, África, Ásia e América do Sul. As pessoas dessas culturas normalmente têm uma rede de informação extensa, valorizam mais o relacionamento pessoal, e compartilham experiências e expectativas semelhantes sobre como o mundo funciona. As pessoas são indiretivas (AFS, 2011: 1).

Já na comunicação de baixo contexto, a maior parte da informação é transmitida explicitamente pelos enunciados: culturas de baixo contexto raramente levam em conta o contexto físico e social para interpretar o enunciado. São encontradas normalmente na Europa Ocidental, Estados Unidos e Canadá; nessas culturas, as relações pessoais são determinadas pelo envolvimento em atividades. Diferente das culturas de alto contexto, sentem necessidade de expor com clareza o que querem transmitir, seja oralmente ou por escrito. As pessoas são diretivas.

Quanto à categoria tempo, Hall (Apud AFS, 2011; 1) entende que as pessoas enxergam a passagem do tempo em continuidade de forma monocrônica ou policrônica. Em um sistema monocrônico, o tempo é compartimentalizado ou dividido entre unidades, uma vez que as pessoas terminam uma atividade antes de iniciarem outra. $\mathrm{O}$ autor acredita que é desconfortável para culturas monocrônicas fazerem mais de uma tarefa ao mesmo tempo, sendo inadmissível a interrupção de uma tarefa. Por outro lado, em um sistema policrônico, várias atividades são feitas ao mesmo tempo, e as relações interpessoais são consideradas mais importantes do que as atividades em si. 
No que se refere à categoria espaço, a partir da mesma fonte, Hall pondera que as pessoas percebem o espaço por meio de quatro sentidos: visão, audição, olfato e tato. Ele aponta que cada cultura tem regras implícitas de como um espaço deve ser utilizado, e que elas variam de cultura para cultura, regulando onde as pessoas devem brincar e trabalhar. Há distinções territoriais para diferentes unidades sociais (bairros) e também espaços destinados apenas para crianças, homens ou mulheres.

Na sequência, o autor informa que espaço pessoal é a distância que precisa haver entre as pessoas para que elas se sintam confortáveis. Hall descreve esse tipo de espaço como uma bolha que cada pessoa tem sempre em torno de si, cujo tamanho varia de acordo com a situação em que a pessoa se encontra e com quem ela está interagindo. $\mathrm{O}$ espaço pessoal varia de cultura para cultura.

Quanto à concepção de comunicação não verbal em AFS (2011: 1-2), pode-se afirmar que a maioria das teorias interculturais de Hall está exatamente nesse campo. Para o autor, comportamentos não verbais incluem expressão facial, movimento e proximidade, entre outros comportamentos que dizem muito e variam não somente entre países, mas também regionalmente.

\subsubsection{Richard D. Lewis}

Após décadas de observação e milhares de avaliações de perfis culturais, a partir de entrevistados de 68 nacionalidades, o linguista londrino Richard D. Lewis (2006: 41) elaborou um diagrama em que dispõe as variações entre as principais culturas do mundo.

Nos subitens a seguir, serão descritos os ensinamentos do pesquisador que interessam a esta pesquisa.

\subsubsection{Categorização de Culturas}

Em sua pesquisa sobre identidade cultural, também chamada de identidade nacional, Lewis (2006: 27) considera várias centenas de culturas nacionais e regionais do mundo e as classifica em três categorias: (i) ativo-linear, formada por pessoas orientadas para a tarefa, planejadoras eficazes, organizadas, frias, fatuais, pontuais; (ii) multiativa, formada por pessoas calorosas, emotivas, falantes, impulsivas, não pontuais; e (iii) reativa, formada por pessoas introvertidas, 
observadoras, polidas, cordiais, conciliadoras, compromissadas, ouvintes atentas, pontuais. Tendo-se conhecimento dessas categorias culturais, pode-se entender melhor o comportamento das diversas nações e culturas, mitigando-se, ou, até mesmo, evitando-se, assim, possíveis choques interculturais. Na percepção do pesquisador, os desentendimentos duradouros entre essas nações e culturas surgem, principalmente, quando há um choque por categoria, e não por diferença de nacionalidade. Ele comenta que alemães e holandeses entram em atrito nacional, mas se entendem e cooperam reciprocamente, visto que ambos são da categoria ativo-linear. Ele também cita como exemplo a enorme discordância que há entre coreanos do sul e japoneses, concluindo que a natureza reativa, comum a ambos, leva-os a um próspero comércio bilateral.

A partir da observação do diagrama triangular proposto pelo autor (2006: 42, Quadro 3.9), publicado em seu livro When Cultures Collide, percebe-se, com clareza, que a disposição dos países não é feita pela distância ou proximidade física entre eles, mas pelo posicionamento escalar relativo à cultura de cada nacionalidade. Cada vértice da figura é ocupado por uma de suas três categorias culturais já apresentadas: ativo-linear, multiativa e reativa. Os países bem próximos a essas ocupações têm as respectivas características mais acentuadas, contudo, podem assimilar, também, características da cultura do outro vértice ligado pelo mesmo eixo a que pertencem. Os que ficam afastados dos vértices são híbridos, pois fazem parte das culturas que estão nos vértices ligados pelo eixo onde se localizam. Assim, como apresenta Lewis ( 2006: 41), a Rússia e a Itália, localizadas no eixo esquerdo do triângulo, são ativo-lineares/ multiativas em graus aproximados pela posição que ocupam. 


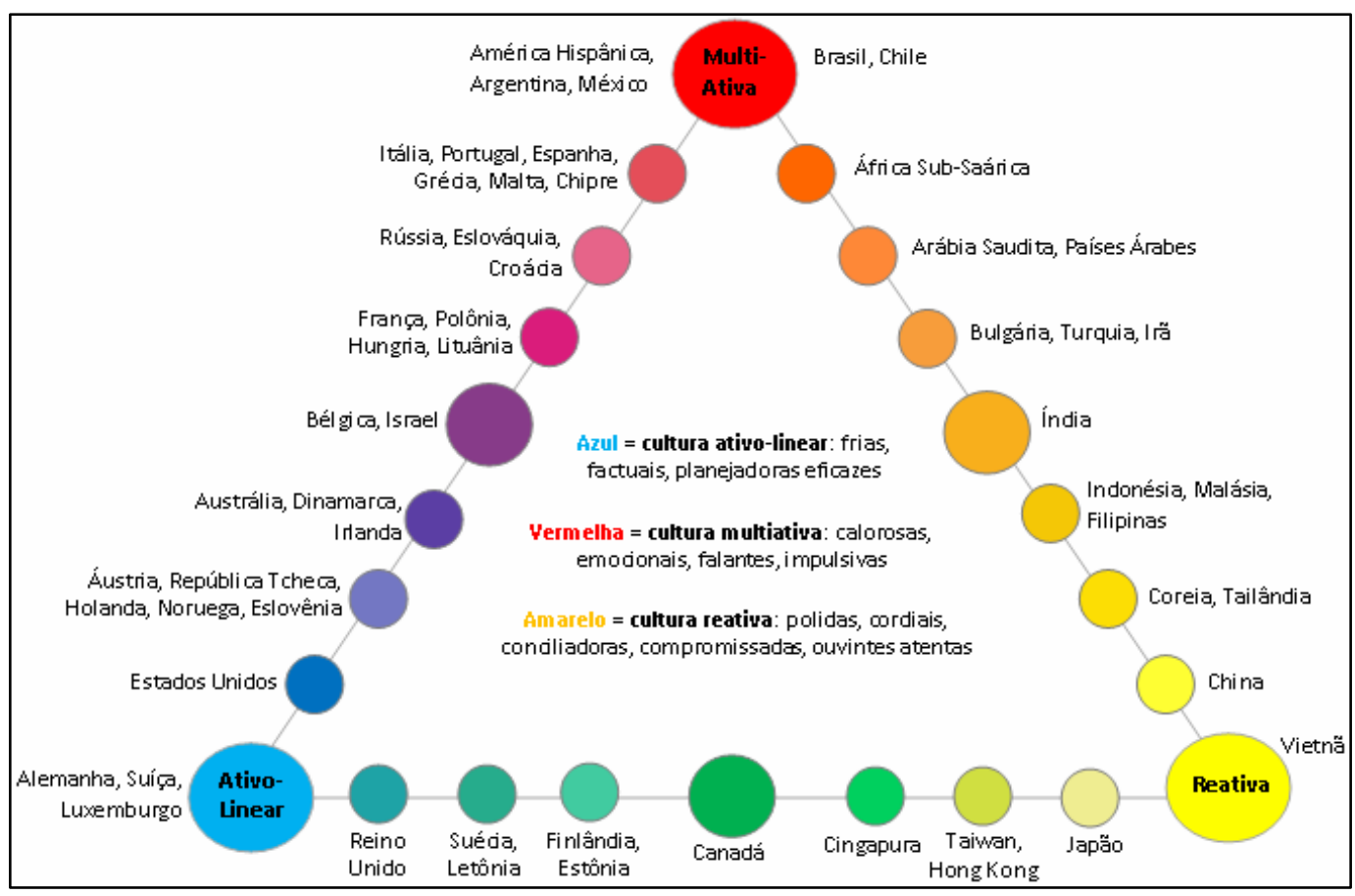

Figura 1 - Tipos de cultura: esquema de Lewis (2006: 41) Tradução livre de Paranhos (2011: 35).

Ainda a partir da mesma Figura, o Canadá, assim como a Bélgica e a Índia, por situarem-se, exatamente, no centro do eixo a que pertencem, segundo Lewis (2006: 42), ocupam posições positivas e produtivas. Comprovando seu ponto de vista, ele esclarece que a Bélgica desfruta de uma economia próspera e democrática devido à manutenção de um compromisso firmado entre administrações de culturas multiativa e ativo-linear, que alia pessoas orientadas para a tarefa a pessoas orientadas para as relações pessoais; informa que o Canadá, por causa da imigração maciça que recebe e do cuidado do governo em preservar todas as culturas, é o país mais multicultural do mundo; e conclui que os indianos, apesar de oradores e comunicadores por natureza, combinam as habilidades calorosas da cultura multiativa com a sabedoria e a cortesia orientais, ou seja, reativas. Além disso, segundo o autor, a Índia herdou um considerável número de instituições britânicas, o que lhe permite o relacionamento com o Ocidente.

\subsubsection{Identidades Nacionais}

Lewis (2006: 27) nos informa que o número de culturas no mundo é maior que os mais de 200 países geograficamente demarcados, devido às fortes variações regionais. Por isso, podem-se observar diferenças de valores, 
comportamentos e expressões linguísticas entre as regiões de um mesmo país. O autor aponta como causa desse fenômeno multicultural a formação de países por grupos de diferentes contextos históricos, com componentes oriundos de regiões distintas. Ora, isso nos permite afirmar que o Brasil e o Canadá, como será visto nos subitens a seguir, foram constituídos desse modo.

\subsection{Brasil}

Colonizado por Portugal, naturalmente, o Brasil herdou e adotou traços culturais da terra de Camões. Na percepção de Lewis (2006: 540), enquanto a Espanha conquistou países na América do Sul por meio de lutas sangrentas, a descoberta da Terra de Santa Cruz ${ }^{1}$ deu-se por acaso, de forma "quase risível em sua descontração". No entendimento do pesquisador, Pedro Álvares Cabral, sem perceber, tinha se desviado da rota do caminho para a Índia, que era seu destino, tendo o único trabalho de erguer a bandeira portuguesa e fincá-la em solo brasileiro para marcar a ocupação lusa. Os escravos negros foram importados de Angola, e os índios foram catequizados para ajudar nas plantações de cana de açúcar. Assim sendo, os colonos portugueses coabitaram com negros e índios, dando origem a mestiços na criação das linhagens da nova nação. $\mathrm{O}$ autor destaca ainda que essa mistura de raças, num clima tropical, originou pessoas com disposição fácil de lidar.

Considerando os portugueses um povo flexível, coletivista, de temperamento mais para tranquilo, que tende a resolver seus litígios e problemas por meio de discussões prolongadas, em vez de por meios físicos, Lewis (2006: 540) os contrapõe aos espanhóis e leva em conta o espírito luso-brasileiro para nos apontar como tolerantes. Ele acrescenta que nós somos felizes por sermos brasileiros, e que acreditamos, implicitamente, no potencial produtivo do país.

Seguindo esse enfoque, o pesquisador nos categoriza como multiativos, orientados para o diálogo, embora aponte que nós tendemos a ser como os americanos: muito futuristas em nossas perspectivas. Como exemplo, afirma que derrubamos um prédio velho para erguermos um novo. Contudo, observa que

\footnotetext{
${ }^{1}$ Logo após sua descoberta, nosso país se chamou Terra de Santa Cruz, depois, Ilha de Vera Cruz e, finalmente, Brasil. (Nota da autora.)
} 
somos tradicionais em relação a costumes familiares e sociais. Quanto à religião, diz sermos, predominantemente, categorizados como católicos, sofrendo influências de religiões africanas.

Com base no capítulo em que Lewis fala sobre o Brasil, pode-se afirmar, quanto aos valores culturais, que nós somos loquazes, exuberantes, emotivos, teatrais, orientados para o futuro e para o grupo, impacientes, orgulhosos por sermos brasileiros, humanitários, amigáveis, tolerantes, fáceis de lidar, criativos, amantes da música e da dança, imponentes, exagerados, patrióticos, otimistas, flexíveis, hospitaleiros, evasivos a dissabores, animados; impontuais, não somos orientados pelo tempo, nem seguimos regras; mantemos relações raciais fáceis e somos indisciplinados.

Em Lewis (2006: 541), fica claro que, por termos o quinto maior território nacional do mundo, riquíssimo em recursos, alguns dos quais ainda pouco desenvolvidos, temos um forte senso de autoconfiança nacional. Corroborando essa afirmação, o IBGE (2015) levantou dados recentes que informam sermos 204.075.000 de habitantes que nos orgulhamos de dizer que "Deus é brasileiro".

Analisando os aspectos culturais dos nascidos e criados no Brasil, Meyer (2013: 20), baseada no diagrama triangular de Lewis (2012), também traz luz às nossas reflexões, reforçando a relevância do uso da teoria do linguista britânico nesta pesquisa. A autora comenta algumas das características que Lewis (2006) nos atribui e acrescenta que o fato de sermos apresentados no eixo da direita do triângulo deve-se à nossa tendência à polidez, cordialidade, atenção ao outro, conciliação e compromisso, atributos peculiares à cultura reativa. Meyer destaca que o posicionamento do Brasil no eixo das culturas multiativa/reativa:

mostra bem a nossa natureza de certa forma híbrida: ao mesmo tempo que calorosos, somos conciliadores e, assim, evitamos conflitos; ao mesmo tempo que prolixos, defendemos a face do outro, dando-lhe atenção; embora impulsivos, somos compromissados (MEYER, 2013: 20).

Adiante, serão tratados os conceitos de Lewis (2006) e os fatores culturais de comunicação, relacionados ao brasileiro, pertinentes a este trabalho. 


\section{A. Espaço e Tempo}

No que se refere à categoria espaço, concordamos com as considerações do pesquisador que, na página 542, afirma que nós, brasileiros, não sentimos desconforto em ficar a pouca distância de nosso interlocutor, trabalhando felizes uns perto dos outros. Bem extrovertidos e táteis, gostamos de abraços. As mulheres, em geral, cumprimentam-se com um beijo em cada bochecha; os homens, com aperto de mãos e com recíprocos tapinhas nas costas ou no ombro. Homens e mulheres, também, cumprimentamo-nos com beijos na face.

Quanto à categoria tempo, observando os brasileiros e generalizando, Lewis (2006: 542) considera que acreditamos ser falta de educação chegar à casa de alguém para jantar na hora marcada, que, em nosso país, os compromissos de negócios raramente começam como programados e, muitas vezes, demoram mais do que o previsto, atrasando, assim, os subsequentes. A partir das observações do pesquisador, pode-se afirmar que nós, seguindo um sistema de tempo multiativo, fazemos bastantes coisas concomitantemente, embora, muitas vezes, em uma ordem planejada. De forma geral, temos tendência a ser bem flexíveis e generosos com nosso tempo, assim como para nos concentrarmos no processo, em vez de focarmos no produto, o que, geralmente, faz com que percamos de vista os objetivos; aceitamos naturalmente a interdependência nos negócios e esperamos ajuda em momentos de perda ou fracasso.

$\mathrm{Na}$ sequência, o linguista afirma que, apesar de não darmos muita importância à pontualidade, se um parceiro ativo-linear insiste, fingimo-nos preocupados com o compromisso assumido; e que, considerando a realidade mais importante do que os horários estabelecidos pelo homem, não gostamos de deixar as conversas inacabadas. Para ele, achamos que a conclusão de uma interação amistosa é a melhor forma de investimento do tempo. Confirmando essa ideia, há as palavras de Meyer (20013: 29), "Para os brasileiros, tempo não é dinheiro, tempo é vida".

\section{B. Fatores Culturais na Comunicação}

No que se refere ao padrão de comunicação, Lewis (2006: 542/543) faz as seguintes observações sobre os brasileiros: falantes e prolixos, usamos gestos e 
expressões faciais para enfatizar nosso ponto de vista; apesar de parecermos excessivamente emotivos, às vezes, só queremos que o interlocutor acredite na sinceridade de nossos sentimentos; somos muito expressivos, principalmente, quando manifestamos descrença, alegria, simpatia ou decepção. Na percepção do autor, achamos que um discurso mais longo consolidará a lealdade como base sobre a qual podemos construir transações futuras e garantir uma aceitação a longo prazo.

Quanto ao hábito de ouvir, na sequência, encontram-se dados que permitem dizer que, devido ao que é apresentado como a exuberância de expressão do brasileiro, nossos hábitos de escuta tendem a ser um pouco irregulares e nossa capacidade de atenção, relativamente curta, pois, mesmo sem a intenção de sermos rudes, interrompemos uns aos outros com ideias próprias. Assim, uma pessoa de outra cultura terá que aprender a fazer o mesmo, para passar uma impressão de que ela acompanha nossos movimentos, gestos e mantém contato visual, ao invés de ouvir atentamente o que estamos dizendo.

Em relação ao comportamento do brasileiro, inclusive em reuniões e negociações, Lewis (2006: 543) afirma que, de modo geral, numa interação, usamos muitos sufixos de diminutivo, altamente adequados para expressar emoções e nuances, modalizando uma declaração dura, suavizando-a. Segundo o autor, somos indiretivos para não melindrar o outro, pois, além de termos ideias muito criativas, gostamos de agradar; por isso, muitas vezes, dizemos às pessoas o que elas querem ouvir, relativizando a verdade e, quando for o caso, apresentando solução para os problemas. $\mathrm{O}$ autor ainda afirma que gostamos de soluções fáceis e imediatas, e os resultados, muitas vezes, decorrem da falta de planejamento de longo prazo.

\section{Como Criar Empatia com os Brasileiros}

Lewis (2006: 544) propõe que, para o estabelecimento de empatia com os brasileiros, precisa-se ter consciência de que, em geral, temos dificuldades na interação com pessoas rigorosas e formais. Ele sugere, como experiência bem interessante e uma boa maneira de nos conhecer, que se aceitem nossos convites para atividades sociais. E continua suas considerações, informando que gostamos de lidar com pessoas boas, que demonstrem preocupação com nossos problemas 
pessoais, bem como com nossa competência no trabalho, pois, assim, percebemos que elas, também, têm seus próprios problemas, e nos sentimos à vontade para lhes pedir conselhos.

O linguista londrino, considerando-nos táteis ao extremo, aconselha aos estrangeiros que aceitem nossos tapinhas no braço ou no ombro e o caloroso abraço, advertindo que não se deve reagir com desconfiança ao nosso calor humano, uma vez que isso é uma demonstração de simpatia e amabilidade. Chamando-nos de impontuais, avisa aos estrangeiros para não se preocuparem com a falta de pontualidade dos brasileiros, já que chegar de 15 minutos a uma hora e meia depois do horário estipulado não é considerado atraso no Brasil. Por fim, diz que não nos aborrecemos com facilidade, pois fazemos parte de uma sociedade muito aberta e informal (LEWIS, 2006: 544).

\subsection{Canadá}

Sobre a contextualização histórica do Canadá, a partir de Lewis (2006: 186), pode-se relatar que, em 1565, um navio, transportando exploradores franceses, afundou na Baía de Hudson. Os sobreviventes, uma vez em terra, encontraram índios locais, e estes, para surpresa geral, responderam-lhes o cumprimento em basco. Esse fato indicou o início do multiculturalismo canadense. Assim, a base para o Canadá multicultural foi posta há mais de 30 mil anos, quando uma gama diversificada de aborígenes cruzou a ponte de terra entre a Sibéria e o Alasca, estabelecendo-se em torno da Baía de Hudson e das costas ocidentais e orientais. Eles eram caçadores, originalmente do interior, mas, como se mudaram para o Leste, cruzando o Norte, adaptaram-se às condições costeiras e começaram a caçar focas e morsas. O pesquisador calcula que mais de 700 grupos da população inuit (membros da nação indígena esquimó) estavam espalhados pelo Norte, cada qual com linguagens e costumes próprios.

O teórico informa que, no mesmo século, outros exploradores ingleses e franceses navegavam pelas águas da América do Norte, à procura de uma passagem que os levasse para os mercados ricos do Oriente. Eles nunca encontraram a rota para a China, mas descobriram um vasto território farto em pesca e em caça de castores, raposas e ursos, muito valorizados por suas peles. Por isso, surgiram assentamentos franceses e ingleses permanentes no início dos 
anos 1600, aumentando em número ao longo daquele século. Os colonizadores eram obrigados a interagir com aborígenes para construir uma herança canadense única. Mais tarde, durante o século XIX e o início do século XX, muitos norteorientais e europeus emigraram para o Canadá em busca de terra e liberdade. Nesse mesmo período, um grande número de chineses e sul-asiáticos também chegou a trabalhar como operários nas minas, na estrada de ferro ou em indústrias (LEWIS, 2006: 187).

Assim, como mencionado anteriormente, pode-se ratificar que, hoje, o Canadá é, indiscutivelmente, o país mais multicultural do mundo. Em 2000, mais de 12 milhões de canadenses, ou $40 \%$ da população, foram apontados como tendo uma origem étnica diferente da britânica e da francesa. Entre os grupos maiores estão o alemão, italiano, ucraniano, holandês, polonês, chinês, vietnamita, coreano, judaico, caribenho, português, finlandês e escandinavo.

Sobre o aspecto linguístico, Lewis (2006: 187) mostra que mais de 60 línguas são faladas por mais de 70 grupos étnico-culturais em todo o país. $\mathrm{O}$ governo canadense é muito ativo na proteção dessa herança e de programas de educação multiculturais e antirracistas que existem em todos os níveis. A exemplo disso, o autor informa que jornais étnicos surgem de forma sistemática em todo o Canadá: só em Toronto há mais de 100. A radiodifusão e a televisão multiculturais prosperam: a cidade tem uma estação de televisão étnica em tempo integral, com um grande número de programas em italiano, ucraniano, alemão, grego, português e chinês. Canadenses de todas as origens culturais têm a oportunidade de contribuir para os objetivos comuns de igualdade, unidade nacional, harmonia social e prosperidade econômica.

O Canadá é a única nação que participou de todas as principais operações de manutenção da paz da ONU e a oitava maior economia do mundo, estando entre os três primeiros países no Índice de Desenvolvimento Humano (LEWIS, 2006: 188). Entretanto, há uma grande rivalidade entre a Inglaterra e a França em solo canadense.

A partir do olhar do pesquisador, pode-se afirmar, quanto aos valores culturais, que o canadense é um povo honesto, amigável, fácil de lidar, prático, econômico, e bem-humorado. Tolerante, mas crítico com os EUA, é modesto, muitas vezes tradicional, justo, gentil, generoso, provinciano, pioneiro, 
independente, discreto, descomplicado, amante da família e da natureza e, por fim, internacionalmente imparcial. O teórico informa que os canadenses são frequentemente comparados aos norte-americanos, com quem mantêm uma recíproca relação de amor e ódio. Sendo o oposto de seus únicos vizinhos, eles se consideram conscientes do mundo, discretos, modestos, comedidos, metódicos nas interações, coletivistas, nacionalistas moderados, multiculturais, crédulos, portadores de complexo de inferioridade ocasional, prudentes, tranquilos, pacientes e conservadores (LEWIS, 2006: 188-189).

Na sequência, apresentam-se os conceitos de Lewis (2006) e os fatores culturais de comunicação, relativos ao canadense, os quais têm pertinência para esta pesquisa.

\section{A. Espaço e Tempo}

No que se refere à categoria espaço, o mesmo autor aponta, nas páginas 189 e 190, o Canadá como o segundo maior país do mundo em extensão ${ }^{2}$. Informa ainda que, com menos de três pessoas por quilômetro quadrado, tem a menor densidade populacional de qualquer país desenvolvido, com exceção da Austrália, e que a maioria dos canadenses, no entanto, vive na fronteira com os EUA, sendo a Região Norte, virtualmente, desabitada. Para atualizar dados, consideremos o site Country Meters (2015), que estima a população canadense em pouco mais de 35.662.000 habitantes.

Quanto à categoria tempo, partindo das ponderações do linguista londrino, pode-se afirmar que os canadenses são, geralmente, pontuais, embora as vastas extensões de terra nas pradarias e no Norte tornem as pessoas mais relaxadas quanto à programação e a outras atividades. Eles não são obcecados pelo conceito americano tempo é dinheiro, sendo que os inuits, em especial, têm seu próprio senso de tempo. Entretanto, em geral, não gostam de perder tempo. Ainda com base nos dados do autor, pode-se afirmar que os canadenses, seguindo um sistema de tempo ativo-linear, fazem uma coisa de cada vez, concentrando-se muito nela e realizando-a num período de tempo programado. Eles acreditam que, dessa forma, são mais eficientes e produzem mais (LEWIS, 2006: 190).

\footnotetext{
${ }^{2}$ O primeiro maior país do mundo é a Austrália (LEWIS: 2006, 189).
} 


\section{B. Fatores Culturais na Comunicação}

Sobre o padrão de interação dos canadenses, Lewis (2006: 190) registra que eles são ouvintes atentos e raramente interrompem um discurso ou uma apresentação. Todavia, destacando-se em debates corteses, têm como princípio educacional básico que até os jovens podem contestar os preceitos dos mais velhos. Assim sendo, é comum, na aprendizagem, o diálogo entre aluno e professor.

No que se refere ao comportamento, os canadenses, em reuniões e negociações, são essencialmente democráticos: as decisões são tomadas com tranquilidade e cautela, uma vez que eles ouvem antes para debater depois. Gostam de interactantes calmos, discretos e bem-humorados, são culturalmente conscientes e fazem questão de dizer que não são americanos. Pragmáticos, procuram entrar em acordo, e as negociações devem conduzir a um plano claro de ação. Adeptos do bom humor, não apreciam discursos intermináveis e tensos (LEWIS, 2006: 190-191).

O pesquisador expõe, ainda, que o Canadá é uma sociedade muito aberta, de tolerância social máxima, que considera tabus o orgulho, o alarde e a ostentação. Sociáveis, convidam as pessoas prontamente para jantar em suas casas, onde a hospitalidade, à moda antiga, mostra que não têm limites. Suas roupas, na maioria das vezes, são confortáveis, mas revelando cuidado com a aparência. (LEWIS, 2006: 190-191).

\section{Como Criar Empatia com os Canadenses}

Para o estabelecimento de empatia com os canadenses, Lewis (2006: 191192) nos revela que se deve ter consciência de que eles esperam que o não nativo, de certo modo, espelhe-se em seus típicos valores de tolerância, calma, razoabilidade, expressões e comportamento discretos. $\mathrm{O}$ autor acrescenta que, embora eles não sejam muito nacionalistas, gostam de ter sua identidade nacional apreciada pelo estrangeiro, de ser distinguidos claramente dos americanos, e reconhecidos como pessoas fáceis de se lidar. Além disso, estão interessadas em conhecer outros países, e desejam ser internacionalmente reconhecidas como populares. O imigrante ou visitante que fala francês pode ganhar fácil a empatia 
dos franco-canadenses, que se isolam em Ontário e em outras províncias, apegando-se aos laços de família, língua e religião.

\subsection{Noruega}

Entre outras características do povo norueguês, as três mais marcantes são o egocentrismo, a teimosia e a imensa capacidade de exame de consciência nacional. Essa centralidade norueguesa é tamanha que Lewis (2006: 344) comenta que, um dia, perguntando a um amigo norueguês como ele faria para categorizar nacionalidades, este lhe respondeu: "Há apenas dois tipos de seres humanos - os noruegueses e aqueles que desejam ser noruegueses".

Pelo olhar do interculturalista, com base no capítulo 37 da mesma obra, pode-se afirmar que o país é seguro, bem organizado e equilibrado economicamente, propiciando aos habitantes oportunidades de bons empregos, garantia de moradia, boa alimentação e um notável sistema educacional.

Para falar do sentimento amistoso existente entre noruegueses e britânicos, Lewis (2006: 345) aponta, como causa, o fato de o sangue viking correr nas veias de ambos. Consequentemente, a Grã-Bretanha é uma grande importadora de produtos noruegueses, e, no inverno, alguns habitantes da Noruega preferem o nordeste da Inglaterra a qualquer parte da Noruega. $\mathrm{O}$ autor acrescenta que outros fatores que ligam os dois países são a democracia com a realeza, o sistema parlamentar, a justiça social, o amor ao ar livre, as expedições para os Polos Norte e Sul, o protestantismo, a navegação, as semelhanças de crenças filosóficas, as atitudes calmas e um senso de humor compartilhado, especialmente, na adversidade. A Noruega, também, tem boas relações com os Estados Unidos e se sente, em muitos aspectos, parte integrante dos países falantes de inglês no mundo.

Lewis (2006: 345) destaca, ainda, o fato de as relações da Noruega com países não anglo-saxões nem nórdicos serem bem enigmáticas. Trata-se de uma nação reservada, orgulhosa e independente, essencialmente nórdica, uma das mais desenvolvidas do mundo. Na concepção do autor, sua eventual adesão ou não à União Europeia e a outras estruturas da Europa, provavelmente, teria menos importância na área econômica do que na esfera cultural. No que se refere ao comércio, ele afirma que, embora vistos como negociantes honestos, noruegueses 
são tidos pelos europeus do Sul como distantes, excessivamente introvertidos, de temperamento forte e de empatia não imediata. São vistos pelos alemães como menos suscetíveis a se influenciar do que os dinamarqueses, os suecos e os finlandeses.

Observando os valores culturais, Lewis (2006: 346) evidencia que a posição segura e confortável, econômica e espiritualmente, da Noruega durante a primeira década deste século é ainda mais reforçada por uma abrangente matriz de valores profundamente enraizados e tradicionais provenientes não só das resoluções do cristianismo protestante, mas também das atitudes e da cultura da Era Viking, adeptas das filosofias pagãs que cultuavam os deuses nórdicos.

Ainda segundo Lewis (2006), embora os noruegueses tenham convicção de suas ideias, constantemente entram em conflito com seus sentimentos. De modo semelhante aos holandeses, eles desejam ser vistos como um povo progressista, tolerante e moderno; contudo, relutam em apagar a tradicional imagem de uma sociedade dogmática. Isso impede a flexibilidade e a facilidade de comunicação, mais facilmente observáveis na Dinamarca. O autor destaca que os valores noruegueses podem ser resumidos em: honestidade, cautela, aversão à extravagância, crença no indivíduo, autossuficiência, autocontrole, senso de humor, praticidade, taciturnidade, teimosia, introversão, amor pela natureza, prudência e previsão, etnocentrismo, preferência pela ação às palavras.

A seguir, apontam-se os conceitos de Lewis (2006) e os fatores culturais de comunicação, referentes ao norueguês, os quais interessam a esta dissertação.

\section{A. Espaço e Tempo}

No que se refere à categoria espaço, como observa Lewis (2006: 347), os noruegueses têm uma baixa densidade populacional, gosto pelo individual e pelo espaço de trabalho. Seus escritórios e outros edifícios públicos são claros, arejados e, muitas vezes, amplos. Sua área de conforto - a "bolha espacial" - é de 47 polegadas (1,2 metros) por pessoa. A natureza do terreno da Noruega gera um amor a grandes espaços abertos, às montanhas e à vida ao ar livre. $\mathrm{O}$ ar marítimo e o ar das montanhas são muito importantes para o bem-estar dos noruegueses. Como muitas comunidades vivem em vales isolados, percebe-se, no país, certo provincianismo. Atualizando dados do autor, uma publicação do site local, 
Population Pyramid (2015), estima a população norueguesa, hoje, em 5.142.000 habitantes.

Quanto à categoria tempo, o pesquisador comunica que os noruegueses, especialmente os da cidade, são bem mais pontuais que os habitantes das áreas rurais e litorâneas. A Noruega não tem transporte público fácil, por isso, abonos são feitos com frequência, para chegadas tardias de longas distâncias, especialmente no inverno. Segundo o linguista, o país pertence a uma cultura que, diferentemente do Brasil, mas como o Canadá, usa o tempo ativo-linear, visto que, no país, as pessoas fazem uma coisa de cada vez, concentrando-se muito no produto e realizando-o dentro de um período de tempo programado. Acham que, assim, são mais eficientes e lucram na produção (LEWIS, 2006: 347).

\section{B. Fatores Culturais na Comunicação}

Tratando-se do padrão de comunicação, em Lewis (2006: 348), percebe-se que as reais qualidades norueguesas e os sentimentos amistosos não são prontamente comunicados em seu estilo de fala. O teórico pondera que climas frios tendem a deixar as pessoas introvertidas, e que noruegueses e finlandeses são os mais tímidos dos europeus. Contudo, nas reuniões, momentos saudáveis de encontro, as pessoas revelam, bem-humoradas, seus sentimentos: todos se colocam e, comumente, entram num acordo. Uma vez tomada uma decisão, não há probabilidade de ser alterada.

Quanto ao hábito de ouvir dos noruegueses, pelo olhar de Lewis, pode-se dizer que eles ouvem de bom humor, mas rapidamente desenvolvem fortes opiniões que $\operatorname{logo}$ são expostas. São orientados por dados e egocentrismo e gostam de imprimir, em sua fala, um toque pessoal, embora não se afastem dos fatos.

\section{Como Criar Empatia com os Noruegueses}

Para o estabelecimento de empatia com os noruegueses, Lewis (2006: 348) aconselha franqueza, diretividade e simplicidade, pois eles estão à procura de honestidade, energia e confiabilidade. Por isso, para um bom relacionamento com eles, deve-se cumprir sempre o prometido, jamais agir de forma desonesta. Levando em conta uma desavença que houve entre a Noruega e a Suécia, no 
século XIX, o pesquisador adverte que não se deve elogiar demais os suecos. Os noruegueses são mais folclóricos do que eles e têm um toque mais pessoal, embora não tão forte como os latinos. O autor orienta, também, a falar sobre as amadas montanhas deles e a convidá-los para atividades ao ar livre.

\subsubsection{Roberto DaMatta}

O antropólogo social Roberto DaMatta morou, por mais de 12 anos, nos Estados Unidos, de onde passou a observar o Brasil em seus detalhes como brasileiro, mas também com um olhar estrangeiro. É pioneiro nos estudos de rituais e festivais, investigando o Brasil como sociedade e sistema cultural. Então, a partir de afirmativas e negativas diante de questões como futebol, carnaval, música, cidadania, comida, mulher, morte, jogo do bicho e das categorias tempo e espaço - em contraste com a cultura estadunidense, por ausências e negativas ele nos revela um "Brasil com B maiúsculo", isto é, uma "Sociedade com valores próprios, que a tornam uma entidade viva, dotada de autorreflexão: algo que se alarga para o futuro e para o passado" (DAMATTA, 2004: 7).

A seguir, serão tratados os assuntos que vêm ao encontro do que será analisado nesta pesquisa.

\subsubsection{Espaços Sociais, Morais ou Éticos}

Assim como em Hall e em Lewis, em DaMatta (2004), a categoria espaço está presente, embora vista sob um ponto de vista diferente. O antropólogo social nos chama a atenção para o fato de a sociedade brasileira poder ser caracterizada a partir dos dois espaços predominantes no cotidiano do brasileiro. Em sua percepção, "A 'casa' e a 'rua' interagem e se complementam num ciclo que é cumprido diariamente por homens e mulheres, velhos e crianças, ricos e pobres" (DAMATTA, 2004: 13). Dessa forma, ele apresenta um sistema composto por dois espaços sociais, morais e éticos chamados por ele de casa e rua, conforme explicitados a seguir.

\subsection{A Casa e a Rua}

DaMatta (2004: 14) aponta que “cada 'casa' brasileira é uma 'pessoa moral': um grupo com a capacidade de reagir em conjunto caso um de seus 
membros seja atingido por algum infortúnio ou problema”. Pelo olhar do antropólogo, as tradições se traduzem em obrigações, e, em família, compartilhamos a celebração obrigatória dos nascimentos, aniversários, casamentos e o sofrimento dos funerais. Ele menciona, também, as visitas às tumbas após a morte, comparando-as a nossas casas no outro mundo.

A partir do autor, pode-se afirmar que, na casa, além de sermos classificados pela faixa etária e pelo gênero, temos dimensões sociais, sentindonos como supercidadãos, pois, segundo ele, só temos direitos. Em suas palavras: “nela somos também governados pelos sentimentos de 'respeito', 'honra' e 'vergonha', e pela oposição básica entre o 'fora' e o 'dentro' e o 'sujo' e o "limpo"” (DAMATTA, 2004: 14). Espaço concomitantemente inclusivo e exclusivo, a casa, no Brasil, pode ter agregados como parentes, amigos, serviçais, animais domésticos e até plantas. Continuando as ponderações sobre esse espaço, DaMatta (2004: 15) aponta que tudo o que ocupa o espaço da nossa casa é bom, belo e decente, e que, sendo um diferencial, contribui decisivamente para o estabelecimento das bases de uma forte identidade social, ajudando na conciliação de nossa existência como indivíduos marcados pela impessoalidade que impera nas ruas, onde somos mais um na multidão, somos subcidadãos, uma vez que, como ele observa em outra de suas obras (1997: 93), pelas regras universais da cidadania, só temos deveres e obrigações a cumprir, pois somos vistos "pela lógica do 'não pode' e do 'não deve"”.

Ainda segundo o antropólogo, congregando uma complexa e fascinante rede de símbolos que compõem a cosmologia brasileira, a casa faz um recorte de um espaço amoroso onde a harmonia deve imperar sobre a confusão, a competição e a desordem que caracterizam o espaço da rua. As negociações - de compra, venda ou troca -, assim como as discussões políticas - causas de acentuação de divergências -, estão excluídas da casa, onde o retorno de favores e presentes acontece sem cobranças; e confiança, amor e lealdade são valores de maior relevância na concepção de parentesco do brasileiro.

Em DaMatta (2004), fica claro que, de toda a sociedade moderna, no Brasil, há uma ordenação bem diferenciada entre o universo da casa e o da rua, o que se comprova em suas palavras: 
Num certo sentido, a casa, onde somos reis e donos, nos protege da rua, onde não somos coisa alguma. Se, portanto, nas nações modernas, casa e rua (público e privado $)^{3}$ são governadas pelas mesmas normas, no Brasil, há uma sensível diferença entre as leis que governam a rua, as instituições do Estado e o espaço público em geral, e os hábitos da casa que estão nos nossos corações (DAMATTA, 2004: 17).

No que se refere ao espaço social da rua, local do trabalho e do famoso batente que muitos consideram um castigo, DaMatta (2004) afirma que não existe, entre as pessoas, o sentimento de amor, consideração, respeito ou amizade; o que há é uma dura realidade onde o perigo pode nos surpreender a qualquer momento.

Contudo, ele afirma que o contraste entre a casa e a rua - dois lados da mesma moeda - é fundamental para conferir sentido à vida do brasileiro. O autor defende ainda que a igualdade de todos perante normas e leis, em que a rua se fundamenta, compensa a hierarquia, em que a casa é baseada. Hierarquia essa estabelecida por ordem de importância, gênero e idade das pessoas. A seguir, ele conclui: “A rua compensa a casa e a casa equilibra a rua” (DAMATTA, 2004: 18).

\subsection{Espaço Ambíguo}

Quando os espaços sociais, morais e éticos casa e rua se sobrepõem, ou melhor, quando as relações de familiaridade e afetividade são transferidas para espaços caracterizados por relações de impessoalidade e de distanciamento, surge o que Porto (2006: 24), também baseado em DaMatta, chama de espaço limítrofe, embora o reconheça como ambíguo, acepção que, doravante, será utilizada conceitualmente nesta pesquisa. Cabe ressaltar que espaço ambíguo não será aqui empregado como um espaço arruado, divisor, ou intermediário que serve de mediação entre o interior e o exterior como janela, varanda, sala de visitas, entrada de serviço, dependência de empregadas, citados por DaMatta (1997: 56); mas como um espaço de sobreposição como será explicado nos parágrafos subsequentes.

DaMatta (1997: 17), a partir da observação do movimento que há entre a casa e a rua, aponta um espaço de conciliação onde "todas as questões são tratadas

\footnotetext{
${ }^{3} \mathrm{O}$ espaço da casa refere-se ao privado, e o da rua, ao público.
} 
debaixo de um prisma pessoal e 'caseiro', familiar, doméstico”. Desse modo, pode-se supor como DaMatta que:

Diante de certos problemas e relações, preferimos englobar ${ }^{4}$ a rua na casa, tratando a sociedade brasileira como se ela fosse uma "grande família", vivendo "debaixo de um amplo e generoso teto" (...), onde o eixo da vida pública (do universo da rua) é englobado pelo eixo da casa (...) a pessoa, a casa e suas simpatias constituem a moldura de todo o sistema, criando uma ilusão de presença, honestidade de propósitos e, sobretudo, de bondade, generosidade e compromisso (DAMATTA, 1997: 17).

Assim, tendo em vista o tema desta dissertação e como exemplos hospital, ou lar para idosos, igreja, casa funerária, cemitério, que são espaços públicos, no momento em que amigos e pessoas conhecidas se reúnem nesses lugares em apoio à família enlutada, compartilhando sentimentos de amor, consideração, respeito, solidariedade, sofrimento, próprios do espaço da casa, surge aí o espaço social ambíguo: quando o movimento da rua não contrasta com o ambiente do lar, mas leva afago para a família fragilizada por um dos grandes golpes da vida.

\subsection{Esfera do Outro Mundo}

DaMatta (1997), referindo-se aos espaços de significação social, além da casa e da rua, menciona a esfera do outro mundo, ou seja, o mundo dos mortos, em oposição ao mundo real. O antropólogo defende que as distinções que podem ser encontradas nesses espaços não são exclusivas, mas complementares, "o que faz com que a realidade seja sempre vista como parcial e incompleta" (DAMATTA, 1997: 48). Em sua percepção, o outro mundo constitui com os espaços básicos de nosso mundo um elo complementar e terminal na sociedade moderna. Na página 18 da mesma obra, o teórico deixa claro que a casa e a rua fazem parte da realidade, “mas o universo dos mortos é a esfera do 'outro mundo'. Tal como ocorre com a casa ou com a rua, o 'outro mundo' é também um importante elemento englobador de muitas situações sociais (...) se associa a um fundamental conjunto da nossa identidade cultural" (DAMATTA, 1997: 18-19).

\footnotetext{
${ }^{4}$ englobamento (Louis Dumont: 1980, Apud DaMatta, 1997: 17) “é uma operação lógica em que um elemento é capaz de totalizar o outro em certas situações específicas."
} 


\subsubsection{Rituais de Passagem}

DaMatta (1987), avaliando os rituais de passagem que observou na cultura brasileira, defende que, via de regra, rituais marcam os momentos importantes na nossa vida, e afirma que os exemplos mais comuns são nascimento, batizado, crisma, comunhão, casamento e funeral. Contudo, adverte que todos os momentos que assinalam dramaticamente uma crise de vida e uma passagem na escala da existência social são rituais de passagem. E, em nossa sociedade, a religião os marca e ajuda a fixá-los.

Na mesma obra, na página 56, compreende-se que os rituais de passagem revelam expressões e valores de uma sociedade, uma vez que "estão presentes em todas as crises de vida". Nas ocasiões solenes, o discurso empregado, as roupas especiais, a "existência de representantes duplos" - no caso de funerais, o corpo e o caixão - revelam e ressaltam o que já é comum: a ordem social constituída e aparente e, também, a contenção dos gestos e do comportamento em geral. Em todo ritual de passagem, além de um discurso peculiar que os presentes podem repetir sem esforço, há gestos típicos e objetos indispensáveis "como o anel de grau no caso das formaturas, as alianças no caso dos casamentos, o bolo de aniversário no caso da passagem de idade" e a urna - caixão ou objeto que contém as cinzas - no caso de funerais.

$\mathrm{O}$ pesquisador defende a tese de que tanto em formaturas como em aniversários, casamentos e funerais, sempre são resgatados exemplos para serem seguidos pelos protagonistas, ou - o que interessa bastante a este trabalho modelos de como se podem consolar, numa cerimônia de velório, familiares, parentes, amigos ou colegas. Ele ainda argumenta que os homens, na busca do sentido profundo para a própria vida, nesses eventos, "sentem que asseguram, de certo modo, a continuidade da vida coletiva, mesmo quando ameaçada pela extinção, como é o caso dos rituais funerários" (DAMATTA, 1986: 56).

O antropólogo social destaca o fato de que é notório que os ritos de ordem têm um centro. Esses ritos podem ser um evento, uma personagem, ou um objeto; em cada um deles, há uma cena básica, ou seja, um centro, "que deve estruturar o rito como um todo, além de ações e cenários periféricos", isto é, nos rituais de passagem, as pessoas estão distribuídas ao redor de um centro que possui um 
sincronismo, uma coordenação com o evento principal. E acrescenta: "tudo acontece de modo orquestrado e em equilíbrio com o evento centralizador de todas as atenções" (DAMATTA, 1986: 56). Por fim, ele argumenta:

Assim, enquanto não se pode jamais chegar atrasado a uma festa carnavalesca, pois o evento começa quando se chega, nos ritos da ordem se corre sempre o risco dessa perda. Isso prova que tais solenidades talvez sejam mais legitimadoras do que simplesmente comemorativas, donde a importância da presença e da atenção de todos a seus eventos centrais (DAMATTA, 1986: 57, grifo meu).

\subsection{Aspectos Linguísticos}

No que se refere aos aspectos linguísticos, importam para este trabalho duas percepções complementares: (i) a linguagem, além de meio de comunicação, é forma "de conhecimento do mundo como significação e de expressão de valores culturais e hábitos comportamentais intrínsecos à respectiva sociedade" (AZEREDO, 2008: 56), conforme já exposto (Cf. 2.1.1); (ii) a competência comunicativa, no dizer de Castilho (2014: 71), é entendida como "a habilidade de veicular conteúdos informativos, exteriorizar sentimentos pessoais e expressar instruções que devem ser seguidas”. Isso justifica a interface de uma abordagem antropológica de cunho social aliada à descrição linguística, uma vez que, aqui, observam-se costumes e comportamentos sociais de brasileiros, canadenses e noruegueses, a partir de dados provenientes da funcionalidade da língua e do estudo cultural de suas respectivas sociedades.

Assim sendo, serão abordados, nesta parte da pesquisa, como instrumentos culturais e sociais de comunicação e interação, o conceito de convenção social ${ }^{5}$ (Cf. 2.2.1.2), as expressões convencionais (Cf. 2.2.1.3) e as expressões idiomáticas (Cf. 2.2.1.5) encontradas no corpus. Cabe ressaltar que, sobre essas expressões em análise, especificamente no Brasil, apesar de existirem em grande número de variantes e serem muitíssimo usadas no cotidiano, ainda há pouca literatura produzida por autores consagrados no estudo da língua portuguesa.

Nessa seara, Tagnin $(2013)$ e Perini $(2010 ; 2003 ; 1999)$ iluminam nossas reflexões situadas no âmbito da semântica e da pragmática (Cf. 2). Ampliando a

\footnotetext{
${ }^{5}$ Tagnin (2013)
} 
base utilizada nesta pesquisa, Azeredo (2008) colabora quanto ao que tange à língua e seus usos expressivos, especificamente, no que se refere aos conceitos de eufemismo e disfemismo, como será visto em (2.2.1.3-B).

\subsubsection{Stella Esther Ortweiler Tagnin}

Com ênfase em Estudos da Tradução, Tagnin atua principalmente nos temas: linguística de corpus, fraseologia, tradução, terminologia, língua inglesa e língua portuguesa. Em 1989, publicou seu primeiro livro sobre expressões idiomáticas e convencionais das línguas inglesa e portuguesa. Em 2005, a autora apresentou a seus leitores a obra atualizada, e, em 2013, publicou nova edição ampliada com exemplos das expressões também em alemão, espanhol, francês e italiano.

Tagnin (2013: 25-26) observa que o nível de convencionalidade sintático das expressões idiomáticas abarca combinabilidade, ordem e gramaticalidade dos elementos linguísticos. Ela considera, também, o nível de convencionalidade semântico imanente desses elementos. Por isso, a voz dessa autora aparece destacada a seguir.

\subsubsection{Unidades Linguísticas Convencionais}

Ao estudarmos uma língua, deparamo-nos com uma série de unidades linguísticas convencionais cujos significados estão situados num determinado contexto de situação e de cultura, e que se tem convencionado chamar expressão idiomática. Tagnin (2013: 15) declara que um aprendiz de língua estrangeira, mesmo sabendo toda a gramática e tendo decorado um dicionário básico da língua-alvo, desconhece, a princípio, o significado desse tipo de expressão.

Essas unidades ocorrem em todos os idiomas, mas, em português, "muito pouco se tem feito na área da convencionalidade" - afirma a pesquisadora na sequência da página. Em sua obra mais recente, O jeito que a gente diz (2013), ela apresenta os tipos de unidades convencionais existentes em inglês e em português.

\subsubsection{A Convencionalidade}

$\mathrm{Na}$ tarefa de pesquisar esse "jeito que a gente diz", Tagnin (2013: 19) chega à conclusão de que as expressões convencionais são aprendidas em blocos, 
e a pessoa que não as conhece pode não entender “certas 'tiradas' humorísticas por elas inspiradas". A seguir, a autora argumenta:

Quando nos referimos ao "jeito que a gente diz" estamos, na verdade, falando de convenção, ou seja, daquilo que é aceito de comum acordo. As convenções linguísticas são os "jeitos" aceitos pela comunidade que fala determinada língua. Assim, podemos chamar de convencionalidade o aspecto que caracteriza a forma peculiar de expressão numa dada língua ou comunidade linguística (TAGNIN, 2013: 19).

Mais adiante, ela argumenta que "a convencionalidade abrange tudo o que é convencional" e, citando Houaiss, afirma entender por convencional "aquilo 'que é de uso ou de praxe; consolidado pelo uso ou pela prática' ou 'que obedece a padrões aceitos; não original, comum'”. Em seguida, define convenção social como costumes de uma sociedade. A partir de sua colocação, podem-se dar como exemplos os cumprimentos de Natal, Páscoa, nascimento, batismo, morte, e, entre outros, o tema deste trabalho: o funeral. A linguista informa que a pessoa pode se expressar entregando ou enviando um presente, cartões, flores, ou simplesmente dizendo algumas expressões típicas para o evento. Usando, mais uma vez, as palavras de Houaiss, ela complementa o conceito de convenção social: "qualquer dos usos ou costumes sociais estabelecidos, de tácita aceitação pelos indivíduos de uma comunidade, que incluem regras de boa educação, de boa conduta etc.”. A pesquisadora também aponta como convenção social as desculpas por pisar no pé de alguém, o agradecimento por um favor recebido, ou até o elogio a um presente recebido mesmo que não se tenha gostado dele. Por fim, ela pondera: "Talvez até pudéssemos dizer que são as coisas que fazemos 'por educação' e que, se não as fizermos, estaremos incorrendo na ruptura de uma convenção social ou num ato de "falta de boas maneiras"” (TAGNIN, 2013: 21).

Na mesma página, a autora defende que essa ideia de convenção pode ser aplicada à língua, tanto no que diz respeito ao aspecto social, ou seja, deve-se saber quando dizer algo, quanto no que concerne ao aspecto linguístico, ou melhor, saber como dizê-lo. Sendo assim, é preciso saber que se deve dizer alguma coisa nos eventos mencionados anteriormente e, também, saber como fazer isso. 


\subsubsection{Expressões Convencionais}

No que se refere aos aspectos linguísticos, Tagnin (2013: 21-22) considera que expressões convencionais são aquelas intimamente ligadas a um fato social, e, também, que existem “outras em que o que é convencional é sua forma”. A partir de sua percepção, pode-se citar como exemplo de expressão convencional social, Meus pêsames, por estar relacionada ao ritual de passagem morte. A linguista apresenta mundos e fundos como expressão convencional devido à sua forma, simplesmente, porque "convencionou-se combinar os dois vocábulos mundos e fundos - e não universos e profundidades, por exemplo - unidos pela conjunção e.” A pesquisadora chama a atenção para o fato de não poder haver alteração na ordem dos vocábulos. Para corroborar seu ponto de vista, ela menciona a expressão doce ilusão, afirmando que, no caso de inversão de ordem, há a perda do tom irônico da expressão original.

\subsubsection{Níveis da Convencionalidade}

No que se relaciona a esse assunto, a teórica afirma que a convencionalidade pode ocorrer em vários níveis da língua. Apoiando-se em estudos de Saussure, ela apresenta a relação arbitrária existente entre uma palavra e seu significado como o primeiro deles, afirmando não haver motivação aparente para uma cadeira ser chamada cadeira, ou seja, não existir relação entre o significado e o significante. Como um caso de exceção, admitindo a existência de palavras "cuja relação com seu significado seja transparente", cita as onomatopeias que imitam vozes de animais e ruídos. Além desse nível básico, a pesquisadora declara a existência de outros como o fonológico, o morfológico, o sintático, o semântico e o pragmático (TAGNIN, 2013: 25); contudo, trata apenas dos que se referem às expressões convencionais e idiomáticas, concentrando-se, assim, nos três últimos níveis mencionados, como se observa no esquema a seguir, apresentado na Figura 2. 


\section{Níveis da Convencionalidade}

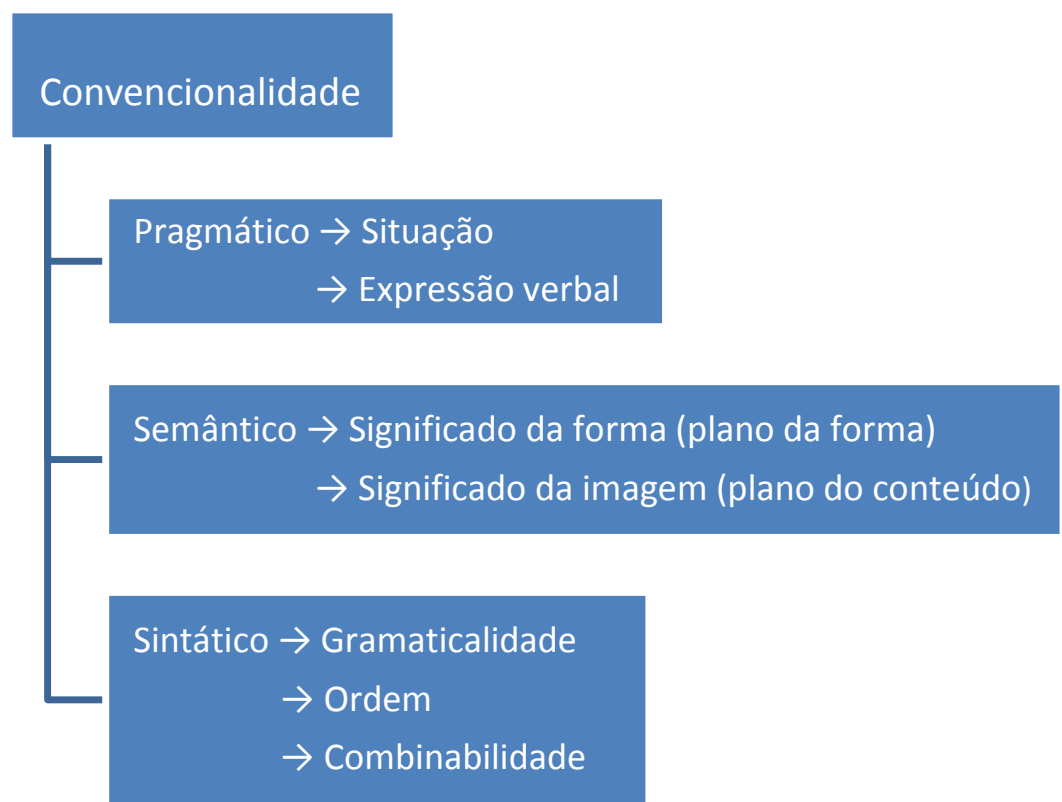

Figura 2 - Tagnin (2013: 27) - Esquema resumitivo adaptado.

Para este trabalho importam apenas os níveis pragmático e semântico da convencionalidade, razão pela qual estão explanados com destaque a seguir.

\section{A. Nível Pragmático}

Como se observa nas palavras da autora, este nível implica o uso da língua em situação de interação face a face. Ela aponta a existência de outros dois aspectos passíveis de convenção, citados anteriormente: "a situação que exige certo comportamento social e a expressão a ser empregada nessa ocasião"; e afirma que a situação de ganhar algo exige certo comportamento social, que é agradecer, e a expressão convencional usada nessa hora é Muito obrigado ou variações (TAGNIN, 2013: 27).

A autora prossegue, ponderando que o comportamento social pode não ser necessariamente expresso de forma verbal, uma vez que, em velórios, funerais e enterros, por exemplo, pode-se expressar o sentimento de solidariedade com um aperto de mão, sem palavras, ou com um abraço silencioso.

\section{B. Nível Semântico}

De acordo com a linguista, neste nível, a convencionalidade é observada na relação não motivada entre uma expressão e seu significado. Para reflexão, ela 
apresenta as expressões kick the bucket e bater as botas, que significam, cada qual em sua língua vernácula, "morrer". A pesquisadora informa que, além do significado das expressões linguísticas, o significado de uma imagem, também, pode ser convencionado, e acrescenta: "São as metáforas que permeiam a linguagem" (Lakoff \& Johnson, 2002 apud Tagnin, 2013: 27). Como exemplo, referindo-se aos campos semânticos de palavras e expressões positivas e negativas, ela argumenta que na "cultura ocidental, por exemplo, tudo que é "para cima' é considerado bom, enquanto o que for 'para baixo' é mau.”. Por exemplo, Ele está num alto astral, Caiu de cama, Ele foi pra debaixo da terra.

Nesssa questão, Azeredo (2008) contribui de forma efetiva ao discorrer sobre a semântica, ampliando e enriquecendo esta pesquisa, principalmente, no que se refere aos conceitos de eufemismo e disfemismo.

O teórico define figuras de linguagem "como formas simbólicas ou elaboradas de exprimir ideias, significados, pensamentos (...), de maneira a conferir-lhes maior expressividade, emoção, simbolismo (...), no âmbito da afetividade ou da estética da linguagem”. Ressaltando que essas figuras não são elementos autônomos e só significam em sua relação com a semântica do texto, ele defende que se deve observar "sua funcionalidade no fio do discurso e perceber o quanto elas são valiosas no processo de construção do sentido da mensagem". O linguista deixa claro que a significação das figuras de linguagem "emana das combinações de que elas participam nos contextos situacional e linguístico de sua ocorrência" (AZEREDO, 2008: 483). Caso esses dois contextos não sejam levados em conta, pode-se fazer uma leitura literal sem que se perceba a funcionalidade da figura "no amplo complexo da textualidade". Por exemplo, se uma pessoa, querendo abrandar um aviso de morte, enviar, para um amigo que esteja totalmente fora do contexto de situação, a mensagem [João viajou.] sem qualquer pista, o interlocutor, provavelmente, não entenderá que se trata de um eufemismo.

Na percepção de Azeredo (2008: 496), o desvio do eufemismo e do disfemismo pode ocorrer, também, "no sentido geral da frase, no entendimento total da mensagem". Retomando o exemplo, se o locutor acrescentar a expressão convencional social Sinto muito, relacionada, entre outras situações, ao ritual de passagem morte, o amigo poderá entender sua nova mensagem [Sinto muito, mas 
João viajou.]. E o autor continua: "Essas figuras manifestam seu rendimento no desacordo da relação de verdade entre o que se diz literalmente e a realidade da qual se fala". Por isso, para que se entenda o sentido atribuído ao enunciado, é de suma importância o conhecimento do referente. Nas palavras do pesquisador:

Por enquadrarem o enunciador em um determinado contexto situacional pelas vias da linguagem, o eufemismo e o disfemismo são recursos estilísticos tipicamente discursivos. Esse enquadramento obedece à tonalidade de expressões politicamente corretas ou incorretas para uma determinada situação, segundo o projeto de comunicação do enunciador, que pode estar relacionado a uma atitude diplomática (eufemismo) ou de enfrentamento (disfemismo) (AZEREDO, 2008: 500).

\subsubsection{Expressões Idiomáticas}

Retornando a Tagnin (2013: 19), ela deixa claro que os linguistas discordam "quanto ao que chamar de expressões idiomáticas", e que estas existem em unidades linguísticas menores, embora não sejam, comumente, assim entendidas.

A autora explica que, no instante em que a convenção passa para o nível do significado, tem-se um caso de idiomaticidade. Ela ensina que:

uma expressão é idiomática apenas quando seu significado não é transparente, isto é, quando o significado da expressão toda não corresponde à somatória do significado de cada um de seus elementos. Assim, bater as botas não significa "dar pancadas com calçado que envolve o pé e parte da perna", mas quer dizer "morrer" (TAGNIN, 2013: 22).

Por fim, a linguista adverte que "toda expressão idiomática é também convencional". É o caso das já mencionadas bater as botas e mundos e fundos, pois os respectivos significados não podem ser depreendidos a partir da soma dos significados individuais de seus elementos. Por outro lado, a expressão convencional de sentido transparente não é idiomática, como pode ser observado em Feliz Aniversário e outras do gênero. Resumindo, as de sentido transparente são chamadas de expressões convencionais sociais, e as de sentido opaco são chamadas de expressões idiomáticas.

Cabe destacar, portanto, que nesta pesquisa, conforme em Tagnin (2013: 22), idiomático é usado no sentido de "não transparente" ou "opaco"; diferente do 
sentido, segundo a teórica, em geral empregado em português, de "referente ou próprio de um idioma”. Para esta acepção, neste trabalho se usa a palavra vernáculo ou natural.

\subsubsection{Mário Alberto Perini}

Até 1995, o conceito de gramática dizia respeito à normatização e ao registro privilegiado por todo "brasileiro culto", e tinha por finalidade perpetuar acriticamente essas vozes. A partir desse momento, ao lado de Rodolfo Ilari e Celso Pedro Luft, Perini inaugura uma nova linha de pensamento, na qual se incita a discussão sobre a necessidade de reflexão acerca de algumas questões de linguagem e validação, inclusive no âmbito acadêmico, de todo e qualquer conhecimento linguístico dos falantes diversos, os quais, ele considera, ostentam uma "sabedoria gramatical oculta" (PERINI, 1999: 11).

O pesquisador, crítico da gramática tradicional e autor de diversos livros, assume sua responsabilidade de elaborar uma descrição ampla e detalhada da realidade linguística no Brasil. Descrição essa que abrange não só a estrutura da língua padrão, mas também, "a descrição da língua coloquial, sua variação social e geográfica, sua história” (PERINI, 2003: 14), entre outros aspectos.

Na mesma obra, numa abordagem prescritiva, portanto, diferente da de Tagnin (2013), o linguista, em suas reflexões sobre lexemas, palavras, morfemas e expressões idiomáticas, na sequência dos parágrafos, destaca a necessidade de o léxico englobar expressões idiomáticas fixas, apontando como exemplo bater as botas e a olhos vistos. Ele defende ser impossível considerar que expressões como essas sejam frases ou sintagmas nominais, uma vez que, oralmente, jamais podem ser interrompidas por hesitações sem que percam o significado da expressão. $\mathrm{O}$ autor pondera que essas unidades não obedecem a uma estrutura sintática nem são interpretadas em separado pela semântica; sendo, na verdade, "itens" compostos e inseparáveis (PERINI, 2003: 347).

Em uma obra mais recente, Perini (2010: 323), ampliando seu próprio estudo anterior, defende que as "línguas naturais mostram forte tendência a fixar sequências de palavras, utilizando-as como unidades, como se fossem palavras singulares". Quando fixadas, essas sequências adquirem um significado próprio, nem sempre derivado dos significados das palavras componentes. $\mathrm{O}$ pesquisador 
apresenta a unidade nado de costas como uma construção cujo significado é derivado das palavras que a compõem, mas que "em geral não admite substituição de itens por sinônimos", por exemplo, natação de costas. Apesar de, em tese, ser a mesma coisa. A seguir, ele aponta bicho de sete cabeças como unidade de significado próprio, sem relação semântica com a construção formada de nominal + de $+\mathbf{S N}^{6}$, e argumenta que, para entender essa sequência de palavras, "é indispensável aprendê-la separadamente, como uma unidade - exatamente como se fosse um item léxico tradicional".

O linguista se ocupa principalmente das expressões idiomáticas, definindoas como sequências de palavras "com significado próprio não derivado dos significados das palavras individuais" - e continua - "são um caso especial das expressões fixas ${ }^{7}$, que incluem também casos como o de nado de costas.". Ora, então, pode-se afirmar que a expressão fixa cujo significado deriva das palavras componentes, apresentada por Perini (2010), corresponde ao que Tagnin (2013) chama de expressão convencional de sentido transparente.

No que se refere às expressões idiomáticas, observem-se as palavras do autor que confirmam o estudo de Tagnin (2013) sobre o assunto:

As expressões idiomáticas sempre violam alguma regra da língua: em geral uma regra semântica, mas às vezes também regras da sintaxe. E às vezes elas contêm itens léxicos que não aparecem em nenhum outro contexto. Na verdade, se alguma coisa define a expressão idiomática é justamente a presença de alguma violação gramatical ou lexical (PERINI, 2010: 324).

Na sequência da página, com intenção de se fazer entender melhor, ele apresenta outros exemplos como mala e cuia e por assim dizer, que violam regras sintáticas; e a granel, advertindo que a palavra granel não existe fora dessa expressão. Visto que esses casos se afastam do que é analisado neste trabalho, passa-se ao destaque do que é de interesse para este estudo, isto é, das regras semânticas que "fornecem o significado dos sintagmas nominais". Como exemplo, ele cita Ao pé da letra, esclarecendo que "é um adverbial que significa

\footnotetext{
${ }^{6}$ Sintagma nominal

${ }^{7}$ Grifos do autor.
} 
'literalmente' (...) [e] não há regra na língua que nos autorize a derivar esse significado das palavras componentes".

Ampliando as informações, Perini (2010: 325) sublinha que pode haver uma expressão idiomática homônima de um sintagma "normal". Por exemplo, ele aponta a última palavra, que, como sintagma, denota "a palavra que foi enunciada depois de todas as outras" ["A última palavra dos Lusíadas é inveja.”]; e, como expressão idiomática, refere-se ao "que está na moda no momento" ["Sapato verde sem meia é a última palavra.”], visto que não há transparência em seu significado.

\subsubsection{Relevância das Expressões Idiomáticas na Descrição}

Quanto ao levantamento das expressões idiomáticas de uso normal no Português do Brasil (PB), na sequência da página 326, Perini recorre a Fulgêncio (2008) para destacar que elas são muito mais numerosas do que se previa, e bastante frequentes na fala. Verificou-se que há mais de 8.000 itens "conhecidos por praticamente todos os falantes".

Diante do fato verificado, o linguista pondera que aí está a importância desse estudo para o conhecimento da língua, e que as expressões idiomáticas "não podem ser consideradas um fenômeno marginal", uma vez que sua listagem “constitui um dicionário". Assim sendo, por fim, ele defende que não há possibilidade de toda ela estar contida em uma gramática, mas “é necessário fazer algumas considerações sobre o que significa a existência dessas sequências para a análise da estrutura da língua" (PERINI, 2010: 326).

Sobre as propriedades das expressões em estudo, o autor deixa claro que, além das construções da língua, ou seja, suas generalizações morfossintáticas e semânticas, somadas às palavras individuais necessárias à construção das frases, o usuário precisa "conhecer sequências de palavras que, formalmente, em geral se assemelham a construções, mas que têm interpretação semântica imprevisível, e são aprendidas uma a uma". Ele acrescenta que "não há meio de apresentar as expressões, a não ser em uma lista pura e simples, porque não existem regras que possam produzi-las" (PERINI, 2010: 327).

Em suma, Perini, considerando a importância das expressões idiomáticas tanto em número quanto em assiduidade de ocorrência na fala, compartilha que: 
o conhecimento da língua inclui, ao lado de regras gerais e itens lexicais individuais, um grande componente formado de peças prontas, que só aparentemente são construções (e às vezes nem isso, como estar careca de), e que precisam ser memorizadas individualmente (Perini, 2010: 327).

Por fim, o linguista esclarece que as expressões idiomáticas não são metáforas, visto que aquelas "são codificadas, e não podem ser interpretadas em seus próprios termos, como as expressões metafóricas". Como exemplo de metáfora, ele cita ["Esse menino é uma bomba atômica."] e comenta que a "metáfora depende da percepção prévia de uma inadequação: um menino não pode ser literalmente uma bomba atômica, daí o ouvinte precisa procurar algum significado aparentado que faça sentido". Já as expressões idiomáticas "ilustram a nossa grande capacidade de memorização, assim como a importância dos elementos memorizados no conhecimento da língua" (PERINI, 2010: 327-328). 


\section{Metodologia}

Toda pesquisa "é um procedimento formal, com método de pensamento reflexivo, que requer um tratamento científico e se constitui no caminho para se conhecer a realidade ou para descobrir verdades parciais". (MARCONI e LAKATOS, 2002: 15). O mundo acadêmico contemporâneo apresenta uma grande quantidade de métodos de pesquisa e, no âmbito das pesquisas dos campos social, antropológico e afins, grande destaque tem sido dado à modalidade "pesquisa qualitativa", conhecida também por não quantitativa ou não padronizada, considerando-se que ela seja mais pertinente por se caracterizar por: utilizar textos como material empírico ao invés de números; partir da noção de construção social das realidades em estudo; utilizar metodologia diversificada adequada ao objeto estudado, aberta ao entendimento do processo; e, sobretudo, estar interessada nas perspectivas dos participantes, em suas práticas e conhecimento cotidiano relativo à questão em estudo.

Autores como Moesch (2000: 62) ensinam que a pesquisa qualitativa se preocupa com um nível de realidade que não pode ser quantificado, trabalha com o universo de significações, motivos, aspirações, crenças, valores e atitudes, ou seja, imerge num espaço mais profundo das relações, dos processos e dos fenômenos que não podem ser reduzidos à operacionalização de variáveis. Essa modalidade, para além de ser apenas um método, permite que se infira mais precisamente, porque tem a flexibilidade necessária para abordar um campo e entrar nele para entender a estrutura de um sujeito ou do próprio campo, em lugar de projetar uma estrutura naquilo que se estuda. (FLICK, 2009: 56).

Partindo do princípio de que a metodologia do trabalho científico tem como finalidade traçar o caminho a ser seguido pelo pesquisador, e sendo o tema proposto, nesta pesquisa, referente ao universo cultural e baseado em narrativas, o estudo sobre os aspectos interculturais presentes nos ritos pós-morte nos países Brasil, Canadá e Noruega tomou como base o método qualitativo.

Para realizar a investigação que deu origem a esta dissertação, apoiamonos em movimentos de naturezas distintas: reflexiva, sistemática e crítica, visando estudar aspectos interculturais que se depreendem das situações de contexto social, como os funerais, quando as linguagens empregadas pelos interactantes - 
comportamentos e palavras - expressam valores que variam de uma cultura para outra. Neste caso em foco, valores do Canadá e da Noruega, por oposição aos do Brasil.

\subsection{O Método da Pesquisa}

O ponto central da pesquisa, que conjuga os campos antropológico, social e linguístico, versou sobre as informações extraídas de entrevistas realizadas online, contando com a colaboração de informantes das três nacionalidades, que falaram sobre suas experiências pontuais nesse tipo de ambiente, relembrando fatos e externando suas impressões pessoais acerca do vivido. Por isso, também, como já informado no item 3.0, nessa investigação, foi adotado o método de pesquisa qualitativa, que, de acordo com Bauer \& Gaskell (2010: 23), lida com interpretações das realidades sociais e entrevistas em profundidade, e não com estatísticas, levando em conta, essencialmente, a natureza do objeto em foco. Esta proposta de estudo pretendeu traçar um panorama sobre os ambientes físicos dos funerais e os comportamentos convencionais pertinentes a cada uma das três culturas apontadas, com o fito de verificar as hipóteses apontadas no capítulo 1, e de sublinhar a importância de se considerar a linguagem humana, verbal e não verbal, como veículo de expressão de valores culturais e hábitos comportamentais, e de exteriorização de sentimentos pessoais, objetivo geral deste trabalho.

A realização de uma pesquisa bibliográfica pertinente ao tema permitiu um aprofundamento teórico, servindo de embasamento para sistematizar os estudos e o processo de pesquisa, facilitando o rico diálogo entre teoria e prática. $\mathrm{O}$ aporte teórico sobre aspectos interculturais aliado às convenções da linguagem visa reunir postulados e análises que possibilitem o registro e um melhor entendimento do processo de "aprendizado" de culturas estranhas ao indivíduo quando em situação social convencional.

A parte prática da investigação apoiou-se, primordialmente, em dados coletados a partir de uma entrevista relato (Anexo 8.1) e em outra, composta por 15 questões de múltipla escolha (Apêndice 02), visando levantar aspectos interculturais e linguísticos no ritual de passagem morte.

Com o intuito de nortear a pesquisa, desenhamos a estrutura que se apresenta no Quadro 1, a seguir: 
Quadro 1 - Metodologia da pesquisa

Objetivo geral: Apresentar a linguagem humana, verbal e não verbal, como veículo de expressão de valores culturais e hábitos comportamentais, e de exteriorização de sentimentos pessoais no que se refere aos rituais funerais.

\begin{tabular}{|c|c|c|}
\hline Objetivos específicos & Metodologia & Instrumentos \\
\hline $\begin{array}{l}\text { 1. Identificar os } \\
\text { comportamentos, a } \\
\text { expressão de sentimentos, } \\
\text { as formas de celebrações e } \\
\text { o como se expressar no que } \\
\text { se refere ao ritual de } \\
\text { passagem morte em três } \\
\text { países de perfis culturais } \\
\text { distintos. }\end{array}$ & $\begin{array}{l}\text {. Levantamento em fontes } \\
\text { secundárias - Revisão } \\
\text { bibliográfica } \\
\text {. Levantamento em fontes } \\
\text { primárias - Conversas com } \\
\text { informantes } \\
\text { representantes das } \\
\text { nacionalidades brasileira, } \\
\text { canadense e norueguesa } \\
\text { transcrições. }\end{array}$ & $\begin{array}{l}\text {. Livros, artigos, material } \\
\text { acadêmico e sites } \\
\text { especializados } \\
\text {. Jornais } \\
\text {. Skype } \\
\text {. Correio eletrônico } \\
\text {. Formulários de entrevista } \\
\text { aplicados aos informantes } \\
\text {. Questionários } \\
\text {. Caderno de anotações }\end{array}$ \\
\hline $\begin{array}{l}\text { 2. Listar e analisar } \\
\text { algumas das expressões } \\
\text { convencionais usadas em } \\
\text { rituais pós-morte, nesses } \\
\text { três países, no } \\
\text { funcionamento da língua } \\
\text { de modo corrente e real, } \\
\text { como instrumentos } \\
\text { culturais e sociais de } \\
\text { comunicação e interação; }\end{array}$ & $\begin{array}{l}\text {. Levantamento em fontes } \\
\text { secundárias - Revisão } \\
\text { bibliográfica } \\
\text { - Identificação e análise } \\
\text { exploratórias das } \\
\text { características dos ritos } \\
\text { após a morte, segundo } \\
\text { relatos dos informantes } \\
\text { representantes das três } \\
\text { culturas em foco nas } \\
\text { entrevistas. } \\
\text { Integração dos dados } \\
\text { recolhidos no campo com o } \\
\text { referencial teórico. }\end{array}$ & $\begin{array}{l}\text {. Livros, artigos, material } \\
\text { acadêmico e sites } \\
\text { especializados } \\
\text {. Jornais } \\
\text {. Dados compilados das } \\
\text { entrevistas diretas com os } \\
\text { informantes } \\
\text {. Imagens }\end{array}$ \\
\hline
\end{tabular}




\begin{tabular}{|l|l|l|}
\hline $\begin{array}{l}\text { 3. Contribuir para a } \\
\text { reflexão sobre a } \\
\text { importância da } \\
\text { competência intercultural } \\
\text { na comunicação entre } \\
\text { interactantes de regiões } \\
\text { diferentes. }\end{array}$ & $\begin{array}{l}\text {.Aprofundamento teórico } \\
\text { situações de } \\
\text { estranhamento e/ou } \\
\text { desconforto vividas pelos } \\
\text { informantes, conforme } \\
\text { relatos. }\end{array}$ & $\begin{array}{l}\text {. Revisão bibliográfica } \\
\text { realizada a priori }\end{array}$ \\
$\begin{array}{l}\text {. Dados compilados das } \\
\text { entrevistas diretas com os } \\
\text { informantes }\end{array}$ \\
. Dados iconográficos \\
. Dissertação escrita sobre \\
o tema (produto final)
\end{tabular}

Com base nas orientações de Bauer \& Gaskell (2010, p. 22), a realidade apresentada nesta dissertação é representada tanto de maneira formal como informal, uma vez que, dentre os instrumentos de pesquisa utilizados, além de textos, utilizamos material audiovisual, conforme descrito no quadro que resume a metodologia empregada na pesquisa.

A delimitação do período em que se realizaram as duas entrevistas foi de julho de 2014 a fevereiro de 2015. Cabe salientar que 06 informantes da primeira etapa, por motivo desconhecido, não compareceram para a segunda fase, tendo sido substituídos já em janeiro de 2015.

Para efeito didático, passamos a apresentar os fatos observados na ordem cronológica.

Inicialmente, com a intenção de atribuir maior credibilidade aos dados e verificar se as pessoas se lembravam de mais alguma coisa depois de haverem tido as memórias estimuladas no primeiro contato, pensamos em utilizar a metodologia já testada e sistematicamente utilizada pela Prof ${ }^{a}$ Olenka Bilash nesse tipo de pesquisa: coletar os dados por meio de três séries de entrevistas. A primeira, com duração de 35 a 50 minutos, constitui-se de um relato de experiência, para não direcionar as respostas; a segunda, de 20 a 30 minutos, uma semana depois; e a terceira, se ainda fosse preciso, de 10 a 15 minutos; em todas, detalhou-se o que fosse necessário da entrevista anterior, ou melhor, foram feitas perguntas cujas respostas explicitassem o que se queria verificar.

Levando-se em conta faixa etária e gênero, a meta era entrevistar, por Skype, cinco adultos de cada nacionalidade, que tivessem tido a experiência intercultural de, no mínimo, dois velórios: um no país de origem e outro no país 
estrangeiro. Contudo, restritos a esse perfil, foi impossível cumprirmos a meta, sobretudo porque era imprescindível que os estrangeiros se expressassem em português, mesmo que não tivessem fluência em nossa língua. Dessa forma, tivemos que entrevistar pessoas com perfis diferenciados, a saber: 02 informantes estrangeiros e 01 informante brasileiro que só tinham assistido a funerais em seu país de origem.

A primeira série de entrevistas começou nos primeiros dias de julho de 2014 e, pelo cronograma traçado no início da pesquisa, provavelmente, em final de setembro já teríamos terminado as três séries. Contudo, não foi o que aconteceu. Relembrando, havia uma amiga que parecia poder colaborar, indicando os informantes noruegueses (Cf.1), contudo, como não conseguimos entrevistar nenhum deles, por motivos diversos, a alternativa foi buscá-los em consulados, igreja norueguesa, e no Programa de intercâmbios da PUC-Rio. Por conta das diferenças de fuso, para conciliar os horários, muitas vezes, demos a disponibilidade de 6: 00 às 2: 00 horas da madrugada. Mesmo assim, apenas no final de janeiro de 2015 conseguimos os dois últimos informantes canadenses, ainda para a primeira série das entrevistas.

Depois da transcrição dessas entrevistas orais, para chegarmos à acurácia dos dados, na comparação dos relatos e das respostas registradas, verificamos se os participantes tinham falado sobre assuntos diferentes, por exemplo, um deles tinha falado sobre alimentos, velas e flores em funerais, e os outros não. Então, após essa investigação, para a segunda série, elaboramos as 15 questões de múltipla escolha, na tentativa de alinhar os depoimentos. Em contato com eles, por Skype, enviávamos o questionário por arquivo para que acompanhassem as perguntas que fazíamos. Dependendo da resposta, na hora, tirávamos as dúvidas, e tudo ficava gravado em áudio para, posteriormente, ser transcrito.

Por todas as dificuldades e por considerarmos satisfatório o corpus construído com o material levantado nas duas primeiras séries de entrevistas, desistimos da terceira série, concluindo a segunda fase da pesquisa em fevereiro de 2015. Contudo, no período de fechamento da análise, quando necessário, voltamos a estabelecer contato com os informantes que participaram das duas etapas a fim de sanar qualquer dúvida. Os dados coletados dos seis informantes que participaram apenas da primeira fase foram descartados. 
Assim, contribuíram para a coleta de dados deste estudo 21 informantes, com idades entre 24 e 77 anos, sendo 13 do gênero feminino e 08 do gênero masculino, de diversas ocupações conforme quadro em que os informantes estão elencados e identificados por números (Apêndice 03). Inicialmente, idade e sexo foram levados em conta nesse método exploratório, mas, quanto à ocupação e à cidade de origem dos entrevistados, não houve nenhum fator determinante; deram-se ao acaso de acordo com a disponibilidade dos que se dispuseram a contribuir com a pesquisa.

Por fim, diante do não cumprimento da meta inicial, houve algumas alterações: entendemos que seria relevante ter uma informante brasileira cuja experiência estivesse restrita a velório, funeral, sepultamento e cremação, no Brasil, a fim de que garantíssemos, mais uma vez, a acurácia desses dados. No que se refere aos outros informantes que compõem quatro grupos, o pré-requisito foi: (a) serem brasileiros, canadenses ou noruegueses, todos falantes de português; (b) terem vivido ou ainda viverem no Brasil e no Canadá ou no Brasil e na Noruega, tendo, assim, condições de relatar um pouco do que observaram do ritual de passagem funeral na cultura do Brasil e/ou de um dos outros dois países em que moraram, ou moram. Esses colaboradores encontram-se distribuídos nos seguintes grupos: (i) 05 brasileiros que moram no Canadá, 03 homens e 02 mulheres, entre 39 e 77anos; (ii) 05 brasileiros que vivem, ou viveram na Noruega, 01 homem e 04 mulheres, entre 42 e 62 anos; (iii) 05 canadenses que moram, ou moraram no Brasil, 02 mulheres e 03 homens, entre 29 e 59 anos; e (iv) 05 noruegueses que vivem ou viveram no Brasil, 04 mulheres e 01 homem, entre 24 e 48 anos. No Apêndice 03, Quadro 14, a informante com experiência apenas na cultura brasileira, exclusivamente, no Rio de Janeiro e em Minas Gerais, é a de número 21.

No gráfico a seguir, visualizamos melhor o número de homens e mulheres em cada país. 
Quadro 2 - Visualização de informantes por gênero

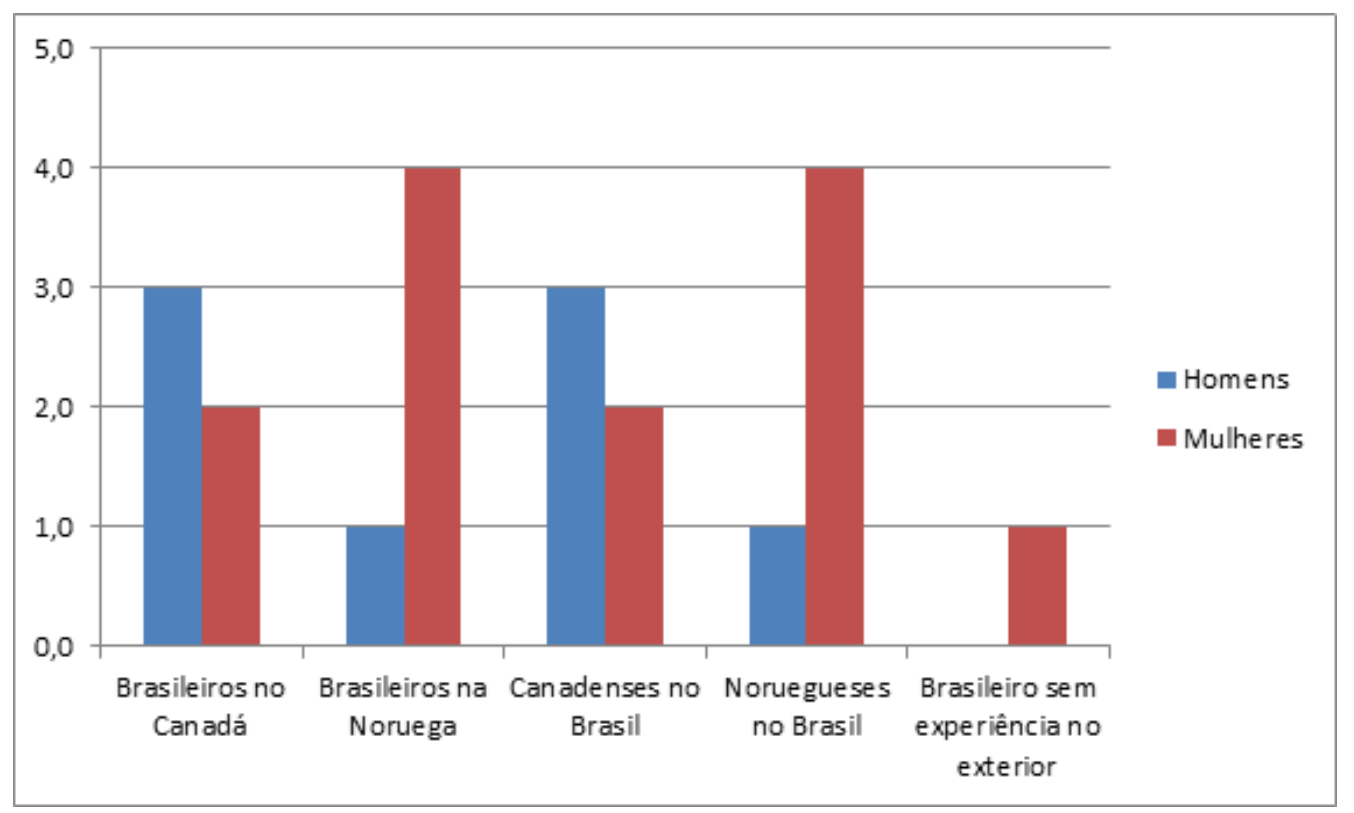

\subsection{O Método da Análise}

Na verificação dos dados, compilamos as expressões empregadas pelos entrevistados, distribuindo-as em Eufemismo para o verbo morrer, Disfemismo para o verbo morrer, Expressões escritas nas faixas, Expressões de cumprimento e Linguagem não verbal (Apêndice 04, Quadro 15). Posteriormente, na análise (Cf. 4.2.1 e 4.2.2), com as devidas adequações, alguns recortes foram feitos desse quadro maior para ilustrar o que se diz em cada grupo de expressões que apresentamos. Os usos dessas expressões ocorrem em língua vernácula e a tradução para o português foi feita pelo próprio informante, mesmo por aquele que sentiu dificuldade para falar em nossa língua.

Cabe esclarecer que, no Capítulo 4, sempre que um recorte de seus relatos da primeira entrevista for citado na análise, além de seu número, serão informados a sua nacionalidade e o número da linha onde o fragmento se encontra. Por exemplo, I 01 (CA), L. 05 identifica o informante canadense de número 1, de cujo relato estejamos utilizando algo que conste na linha 5. Como a informante de número 16 tem dupla nacionalidade, brasileira e norueguesa, ela será representada por (BR/NO). Quanto aos recortes da segunda entrevista, no lugar do número da linha será informado o número da questão, sendo referido como I 02 (CA), Q. 03, por exemplo. No item 4.3, ao comentarmos as respostas de cada quadro, 
corroborando ou refutando nossos teóricos, citaremos apenas o número do informante.

No que se refere à transcrição, para o objetivo deste trabalho, não houve a necessidade de usarmos a transcrição fonética, por isso, realizamos um tipo simplificado e, respeitando a coloquialidade do gênero entrevista, reproduzimos a oralidade do informante tanto nos aspectos lexicais, morfológicos, sintáticos como a constante quebra da construção frásica -, semânticos e fonêmicos, e inclusive quanto ao fluxo das ideias que nem sempre foram concluídas e, às vezes, foram retomadas em outros momentos, quando já se estava abordando outro aspecto relativo ao tema. Em geral, essas retomadas foram feitas à medida que o entrevistado se lembrava de algo anteriormente referido, ou quando tivemos alguma dúvida. $\mathrm{O}$ procedimento, às vezes, pode ter comprometido a coesão textual escrita, mas não a coesão interna na interação entre a entrevistadora e o informante. Esses aspectos da oralidade ocorreram mais nos relatos de estrangeiros e de brasileiros que moram há muito tempo no exterior, usando o inglês como L2.

As informações coletadas, tanto nas entrevistas quanto em dois e-mails enviados por uma informante que se entusiasmou em contribuir e em figuras, foram transformadas em dados significativos para uma consideração ao final desta investigação. Os relatos da primeira entrevista e os e-mails recebidos encontramse em Anexo, 8.1 e 8.2, respectivamente. As respostas ao questionário da segunda fase estão compiladas no item 4.3, por grupos de informantes, nos Quadros 7, 8, 9,10 e 11, em função do interesse desta pesquisa. No item 4.4, imagens escolhidas na Internet e uma foto recebida por um dos e-mails são utilizadas para ilustração de fatos narrados e apresentação de um evento pós-morte, sem marca cultural, ocorrido no Brasil. 


\section{Análise}

Neste ponto do trabalho, passa-se à observação dos dados coletados, através das lentes culturais dos autores aqui estudados, para naqueles verificar quais são os valores culturais, os comportamentos sociais e os sentimentos pessoais que emanam das linguagens verbal e não verbal em sua convencionalidade, tendo em vista as culturas brasileira, canadense e norueguesa, em contextos de situação pós-morte. Observe-se, ainda, que há uma rica interação entre o que dizem os teóricos, em recíproca corroboração - por isso transitam entre as duas partes deste capítulo -, e o conteúdo documentado pela pesquisadora.

A análise apresenta-se dividida em três partes. As duas primeiras Aspectos Culturais e Convencionalidade e Linguagem - capitais, posto terem sido esses os pilares nos quais se assentaram as reflexões que suscitaram a crítica sobre o tema desenvolvido na pesquisa, conforme anunciado no início desta Dissertação. A terceira foi acrescida aos planos iniciais, no momento da escritura do texto da Análise, diante da riqueza dos relatos oferecidos pelos informantes, os quais suscitaram a observação de outros elementos pertinentes ao estudo da interculturalidade. Esses achados reúnem aspectos relevantes que serão esclarecidos no item 4.3.

\subsection{Aspectos Culturais}

A partir do conceito de Cultura de Laraia (Cf. 2.1.1) aqui selecionado, realizamos um estudo comparativo tendo em vista o fato de que indivíduos de culturas distintas podem ser identificados com facilidade não só pela evidência das diferenças linguísticas, mas também pela maneira de agir, vestir-se e comportar-se socialmente no ritual de passagem morte. Dessa forma, as teorias explanadas no Capítulo 2, muitas vezes, complementam-se, propiciando-nos a riqueza de um olhar reflexivo sob vários prismas, quando acompanhamos seus vieses de interpretação dos fenômenos culturais que analisam, cada qual, de seu lugar de atuação.

Alguns dos dados coletados na pesquisa nos revelam que, no que se refere aos aspectos culturais do Brasil, Canadá e Noruega nos rituais de funeral, há 
diferenças não só entre as nações, mas também internamente, nas regiões que compõem cada um desses países. Por exemplo, a informante 21 relata ter assistido a velórios em lugares variados de seu país, o Brasil, onde em regiões distantes dos grandes centros urbanos - como herança de traços culturais da terra de nossos colonizadores (Cf. 2.1.3.2.1) -, o corpo ainda é velado na casa da família enlutada, o que já não se vê no Rio de Janeiro. Nos trechos destacados a seguir, ficam evidentes as diferenças de conduta social de situações de contexto na capital e no interior:

\section{21 (BR), L. 81-89}

(...) numa cidade do interior de Minas, Guarani, eu assisti (...) ao velório clássico do interior. De manhã cedinho passa um carro de som tocando músicas clássicas. Interessante porque eu já tinha assistido em outra cidadezinha do interior de Minas, e sempre são as mesmas composições Bachianas de Heitor Villa-Lobos. E dizem: "A família de fulana de tal comunica o seu falecimento e informa que o corpo está sendo velado em sua casa, e o enterro será às tantas horas", e convida todo mundo. Tem o tal do bolinho de chuva, o cafezinho, a cachacinha, tiram o chapéu, entram e cumprimentam os familiares. A casa fica com portas e janelas abertas. O falecido fica no caixão em cima da mesa da sala. Eu olhava de fora e via as pessoas servindo coisas em bandejas. (sic)

\section{19 (BR), Q. 4}

Lá [Tocantins], tem café, chá, almoço, janta, lanche da tarde. É normal a casa ficar aberta. A funerária oferece uma placa luminosa onde está escrito: Família em luto. A gente pendura na porta da sala. A casa fica toda aberta, portas e janelas. Quem quiser pode entrar. Lá, não tem muro. Colocam músicas que a pessoa gostava. Mas isso não é comum, não. (sic)

\section{14 (BR), Q. 4}

Em Goiânia, tem cânticos religiosos. As pessoas chegam famintas. Sempre tem que ter pão com manteiga, café, feijão, arroz, carne, salada. (sic)

\section{21 (BR), L. 92-98}

$\mathrm{Na}$ cidade grande, o serviço funeral oferece maquiagem. De um modo geral, eles incluem no pacote (...) Acho que o fazem para amenizar a fisionomia, para os convidados não verem uma aparência tão diferente da que teve em vida. Perguntam também se os familiares querem que coloque algum colarzinho. Quando a pessoa era muito vaidosa, parte da família fazer a maquiagem porque sabe que ela nunca gostaria de aparecer publicamente sem pintura. No pacote básico, há flores dentro do caixão, contornando o corpo e uma coroa fora. (sic) 
Os episódios narrados vão ao encontro do pensamento de Hall (Cf. 2.1.2) que, relacionando contexto e significado, defende que a linguagem verbal e comportamentos não verbais variam não somente entre países, mas também regionalmente. Os relatos ainda corroboram Lewis que, com outras palavras, chama a atenção para o fato de haver fortes diferenças de valores, comportamentos e expressões linguísticas entre as regiões de um mesmo país (Cf. 2.1.3.2). Comprovando as ponderações desses pesquisadores, apresentamos outros exemplos encontrados no Canadá e na Noruega, países de cultura ativo-linear, onde, em princípio, as pessoas não expressam as emoções em público:

\section{04 (CA), L. 55-61}

Quando minha mãe faleceu, (...) A celebração da vida, pelo nome, era pra ser uma coisa alegre, mas muita gente chorou do mesmo jeito. (...) Eu chorei muito em público. $\mathrm{O}$ canadense chora em público. $\mathrm{O}$ brasileiro é menos reservado, menos conservativo nesse sentido de não ter medo de mostrar os sentimentos. De minha parte, eu chorei do mesmo jeito, do mesmo tanto. (sic)

\section{07 (NO), L.105-108}

Eu sou uma pessoa que choro muito. Eu já chorei antes quando meu pai me falou que ela não estava bem, ela está ruim, aí eu já choro. Eu chorei, chorei, devo ter chorado uns 7 dias ou mais. No dia do enterro, eu chorei, chorei demais, choramos, assim, mas eu não sei pela minha família, porque choraram, mas não mostraram assim. (sic)

\section{09 (NO), Q. 6}

Quando falam do falecido, no funeral, eu sempre choro, até no funeral de pessoas que não são muito próximas. Os filhos também choram. (sic)

\subsubsection{Contextos e Significados}

Como anunciado desde a introdução, este é um trabalho também de cunho linguístico que se calça em pesquisadores de várias searas para a ampliação e o enriquecimento deste estudo. Assim, levando em conta as variações regionais, a partir do diálogo entre os autores, passamos à interpretação dos dados, utilizando as noções de cultura de alto contexto e de baixo contexto, das categorias de tempo e de espaço como colaboração de Hall (Cf. 2.1.2), ampliando e corroborando o pensamento de Lewis (Cf. 2.1.3). A verificação da categoria espaço de DaMatta 
(Cf. 2.1.4) em nosso corpus, por não ser analisada pelo antropólogo sob um prisma físico, mas social, moral e ético, será procedida à parte, em outro subitem.

No que se refere às culturas de alto contexto e de baixo contexto (Cf. 2.1.2), os dados contribuem para a confirmação da identidade nacional que Lewis (Cf. 2.1.3) atribui aos três países, uma vez que confirma a característica de diretividade e de indiretividade próprias, respectivamente, das culturas ativolinear e multiativa. Isso se percebe no modo como canadenses, noruegueses e brasileiros se expressam em contextos de situação pós-morte: nós, utilizando-nos de expressões notadamente mais informais ou, às vezes, mais líricas, como Dormir como um passarinho; enquanto os indivíduos das outras duas nacionalidades expressam-se, em geral, com maior formalidade, exemplificando, por analogia, nesses contextos, aspectos de suas culturas que se afastam da brasileira. Para melhor compreender essa ocorrência, observe-se o Quadro 3 que correlaciona o dito com o vivido:

Quadro 3 - Contextos e significados

\begin{tabular}{|c|c|}
\hline Brasil & "ABOTOAR O PALETÓ" \\
\hline \multicolumn{2}{|l|}{ •। 21 (BR), L. 70} \\
\hline \multicolumn{2}{|c|}{$\begin{array}{l}\text { As pessoas exacerbam tanto a coisa do social que, quando morre uma pessoa } \\
\text { famosa, as pessoas tiram até selfies com o morto e colocam no Face. (sic) }\end{array}$} \\
\hline \multicolumn{2}{|c|}{$\begin{array}{l}\text { - } 14 \text { (BR), Q. } 7 \\
\text { Em Goiânia, tem palavras e gesto afetuosos como abraço, ou apenas abra } \\
\text { demorado. No Canadá, palavras com aperto de mãos. (sic) }\end{array}$} \\
\hline Canadá & "ACONTECER UM ACIDENTE FATAL" \\
\hline \multicolumn{2}{|l|}{ - I 05 (CA), L. 74} \\
\hline \multicolumn{2}{|c|}{$\begin{array}{l}\text { No funeral, você não fala com a família. O padre fez a missa, depois, a gente vai pra } \\
\text { enterrar o corpo. (sic) }\end{array}$} \\
\hline \multicolumn{2}{|c|}{$\begin{array}{l}\text { - } 12 \text { (BR), Q. } 15 \\
\text { No Canadá (...) Por outro lado, me incomoda a falta total da expressão de } \\
\text { sofrimento. (sic) }\end{array}$} \\
\hline Noruega & "JÁ ACABAR" \\
\hline \multicolumn{2}{|l|}{ •l 09 (NO), L. 98} \\
\hline \multicolumn{2}{|c|}{$\begin{array}{l}\text { Nós somos mais diretos para falar sobre a morte. Para avisar nossa família, a gente } \\
\text { falou: "Ela morreu". Eu, para meus filhos, sem dúvida, disse: "Vovó morreu. E, agora, } \\
\text { a gente não sabe onde ela foi.". (sic) }\end{array}$} \\
\hline \multicolumn{2}{|l|}{ •I 06 (NO), L. 61} \\
\hline \multicolumn{2}{|c|}{$\begin{array}{l}\text { Só cumprimentam com aperto de mão.( ... ) O momento de abraços entre os } \\
\text { familiares só em casa, em público, não. (sic) }\end{array}$} \\
\hline
\end{tabular}


O brasileiro é de cultura de alto contexto, pois além de ser indiretivo, tendo o maior número de expressões conotativas e empregando-as com frequência, expressa-se pelo contato físico com abraços, beijos, tapinhas nas costas. Valoriza mais o relacionamento pessoal e compartilha mais o sofrimento numa situação de luto. Isso confirma sua cultura multiativa. Diversos são os exemplos comportamentais que explicitam um modo leve de encarar as adversidades. O nosso jeito brasileiro nos identifica no cenário cultural mundial, em que somos conhecidos pela graça, pelo deboche, pelos textos cheios de humor, mesmo - ou sobretudo - quando a ocasião pediria luto, denotativa ou conotativamente. Assim acontece quando o tema versa sobre nossos fracassos na política, no esporte, na economia etc; sempre temos uma charge, uma piada sobre nós mesmos que causa espanto aos mais sérios, enquanto ajuda a aliviar o peso que nos vai na alma; daí ousar fazer uma selfie num velório, ou expressar o sofrimento por lágrimas em público.

Por seu turno, o canadense e o norueguês são de cultura de baixo contexto, pois, em geral, expressam-se explicitamente por palavras, levando em conta, raras vezes, o contexto social para interagir. Nessas culturas, por exemplo, as crianças nem de longe têm assegurado um lugar tão central quanto, aqui, as crianças brasileiras. Para os pais, a preocupação com sua educação faz com que os mimos, tão frequentes em nossa cultura, sejam poucos, para não serem nocivos à formação do futuro adulto. Muito natural, portanto, que sejam comunicadas da morte de algum ente de forma direta, objetiva - Vovó morreu. -, como se, assim, fossem logo chamados à realidade da vida. Canadenses e noruegueses mostram-se mais diretivos na relação face a face e, naturalmente, isso se revela na situação aqui em foco. Além de, em geral, quase não usarem palavras e expressões conotativas, avessos ao contato físico, em geral, limitando-se ao aperto de mãos nos cumprimentos, são extremamente contidos em relação a expressar os sentimentos em público, e as relações pessoais são determinadas pelo envolvimento em atividades. Isso se comprova nos seguintes relatos:

\section{19 (BR), L. $98-99$}

Geralmente cumprimentam com Meus pêsames, Minhas condolências. Eles são diretos, usam a palavra morreu. (sic) 
I 14 (BR), Q. 7 [Falando dos cumprimentos.]

(...) No Canadá, palavras com aperto de mãos. (sic)

\section{07 (NO), Q. 7}

Tem gente que só cumprimenta com palavras e acena com a cabeça. É muito impessoal. (sic)

\section{20 (BR), Q. 6 [Funeral na NO.]}

Algumas pessoas ficam emocionadíssimas, ficam vermelhas, mas não desce uma lágrima em público. Outras secam com um lencinho no canto do olho e respiram fundo para se acalmar. (sic)

\section{13 (BR), Q. 6 [Funeral no CA.]}

Quando expressam a emoção, desce uma lágrima, e eles pedem desculpas. (sic)

Contudo, tanto no Canadá quanto na Noruega, foi identificada uma variação de comportamentos, o que se comprova em:

\section{05 (CA), L. 28-30; L. 71-76}

Os familiares e outras pessoas vão vestidos de terno preto, gravata. Muito formal. As mulheres vão de roupa preta muito formal, muito chique. Não me lembro de ver usar roupas de cor. (...) (sic)

Meu irmão faleceu quando eu tinha nove anos, e ele tinha treze anos. A gente tinha um wake, e alunos da classe dele chegava no funeral e, depois, foi enterrado lá, perto da casa dos meus pais. $\mathrm{O}$ wake foi na casa de funeral. Foi uma coisa bem difícil. Chegava quase 80 alunos e todo mundo chorava, muita gente chorando. No funeral, você não fala com a família. O padre fez a missa, depois, a gente vai pra enterrar o corpo. Não lembro muito o que aconteceu depois, não lembro de um festa qualquer. (sic)

Observa-se que, apesar de o informante apresentar os costumes da cultura canadense quanto aos ritos fúnebres, no decorrer de seu relato, ele descreve experiência própria em que alguns dos elementos variaram do habitual: em vez de um ambiente "muito formal", ele fala em "todo mundo chorava" e, embora o costume seja "comemorar", ele diz não se "lembrar de um festa qualquer" (sic).

O norueguês, também, dependendo da região, pode usar expressões conotativas e, com exceção de Oslo, onde os dados mostraram que as pessoas são mais frias, há regiões em que nem empregam a palavra morrer. Apesar de, em 
geral, serem diretivos, há os que se cumprimentam com abraços, embora de forma mais fria do que o brasileiro. Isso se observa nos seguintes relatos:

I 20 (BR), Q. 1 [Falando da NO.]

As pessoas são muito formais e tendem a ser muito diretas. Elas não utilizam eufemismo como se usa no Brasil, mas sempre usam uma expressão atenuante. Ex.: Sinto muito, mas seu pai morreu. (sic)

\section{I $16(\mathrm{BR} / \mathrm{NO})$, L. 62-65}

O povo lá [NO] não é de se abraçar, de se beijar, não. As pessoas são mais de cumprimentar, e quando tem o abraço, antes tem o aperto de mão. Quando são duas mulheres, amigas íntimas, primas, vão direto pro abraço. (sic)

Quanto à categoria tempo, em consonância com o pensamento de Hall (Cf. 2.1.2), que atribui o sistema policrônico de tempo ao brasileiro, e o monocrônico aos canadenses e noruegueses, Lewis (Cf. 2.1.3), com outras palavras, nomeia esses sistemas, respectivamente, como tempos multiativo e ativo-linear. O corpus construído para este estudo contém exemplos que ilustram claramente a acepção de Hall (Cf. 2.1.2) como este trecho recortado de uma das entrevistas:

\section{21 (BR), L. 11-17}

A gente vai pelo social, claro, estamos preocupados, naquele momento, com as pessoas que ficaram, que estão sepultando o seu ente. As conversas acabam, muitas vezes, até destoando da situação. Em alguns momentos, eu estive pensando, recentemente, muito recentemente, a semana passada, estive num funeral. A gente quase que fica, assim, aguardando uma possibilidade de encontrar com pessoas que a gente sabe que vão estar ali e que a gente não vê há muito tempo e tem vontade, então, de conversar, de perguntar. É uma oportunidade de encontro, né? E, aí, a conversa acaba sendo até destoante daquilo ali. (sic)

Nesse fragmento, o brasileiro se enquadra no perfil de cultura policrônica, pois as relações interpessoais são consideradas mais importantes do que as atividades em si. Além do que o exemplo mostra, os brasileiros fazem várias atividades ao mesmo tempo. Por isso, suportam participar de um funeral em 24 horas após a morte e ainda se preocupam em serem sociáveis com as pessoas 
presentes, aceitando e retribuindo gestos de carinho. Nesse curto período, eles dividem o tempo entre providenciar o sepultamento, ou a cremação, contratando um serviço funerário; avisar aos familiares e amigos; e conviver com a perda, em público, sem ainda ter tido oportunidade de extravasar as emoções. Isso seria extremamente incômodo tanto para canadenses quanto para noruegueses, que são de cultura monocrônica, pois eles sempre fazem uma tarefa de cada vez, sendo desconfortável interrompê-la, conforme vimos em Hall (Cf. 2.1.2). Por essa razão, pelo menos por cinco dias, eles se recolhem em casa. Dessa forma, para as pessoas dessas culturas é mais possível aparecer sereno ao funeral e conseguir conter as lágrimas, pois já as derramaram em quantidade no aconchego do lar, sem que nenhuma visita os incomodasse. Faz parte da convenção social de seus países. Nos dados, houve informante que atribuiu o choro do brasileiro em público, nos funerais, a essa falta de tempo para processarmos a morte; ficou evidente que essa corrida contra o tempo só cabe na nossa cultura, deixando no mínimo intrigados, igualmente, os indivíduos canadenses e noruegueses:

I 02 (CA), L. 6-9

Aqui, no Canadá, temos uma semana ou mais para pensar o que passou, quem morreu. Então, no funerário, a gente parece que não sofre, a gente tem mais tempo, tá mais calmo. No funeral, no Brasil, a gente tava chorando, chorando. Acho que é a questão do tempo. Parece que o sofrimento é bem evidente porque a morte foi ontem. (sic)

\section{09 (NO), L. 15-18}

Então, a coisa que mais toca é aquele rapidez, aquele estresse de não ter a possibilidade de refletir, de sentir primeiro a morte de uma pessoa que você gosta. Você só tem que correr pra resolver tudo. Muito complicado, acho pra um ser humano. (sic)

\section{06 (NO), L. 1-9}

O funeral no Brasil é praticamente feito em 24 horas. Dizem que pode ser em até dois dias, mas, pelo que vejo, as pessoas correm pra enterrar logo. Isso me chama muito a atenção porque, na Noruega, não é assim. O resultado que eu senti é que as pessoas estão ainda muito mexidas, muito consternadas, e o ambiente é extremamente triste com muito choro. É um negócio, claro que muito emociona (...), as pessoas estão despreparadas, então, sofrem muito no dia seguinte.(sic) 
Focando a análise no que se refere à noção da categoria espaço, e compreendendo que Hall (Cf. 2.1,2) e Lewis (Cf. 2.1.3) se aproximam, os dados corroboram as ideias dos dois pesquisadores tanto no que se relaciona ao espaço físico, quanto ao que diz respeito ao espaço pessoal. Quanto aos espaços físicos convencionais que reafirmam a postura de Hall, encontramos o cemitério, no contexto de situação sepultamento, em comum aos três países. Quanto a outros eventos pós-morte, os espaços variam de cultura para cultura. No Brasil, o velório, o funeral, o sepultamento ou a cremação, a missa de corpo presente - caso haja -, em geral, são realizados em espaços específicos, no cemitério. Entretanto, no interior do país, há certas regiões em que o velório é na residência da família enlutada (Cf. 4.1), e, em Tocantins, antes do sepultamento, há um rápido funeral na igreja como se pode observar no relato a seguir:

\section{19 (BR), L. 137-141}

Minha mãe morreu no hospital, e a funerária levou o corpo do hospital pra casa, no dia seguinte, foram meus irmãos que levaram o caixão até o carro da funerária, e levamos o corpo até a igreja. (...) chegamos na igreja às $8 \mathrm{~h}$ e antes das $9 \mathrm{~h}$ levamos o corpo para o cemitério. (sic)

No caso de famílias católicas, as missas de Sétimo Dia, de meses e de anos são realizadas na igreja. Nos outros dois países, se a família for católica, também há a celebração dessas missas. Nos países de cultura ativo-linear, os dados apontaram, como espaços comuns, o cemitério para o sepultamento e a casa funerária para a cremação, entretanto, a informante 07 (NO) falou que, em sua cidade, o crematório independe da funerária e da igreja. Já o velório, dependendo da região e também da família, pode ser: (i) imediatamente após a morte, no lugar onde a pessoa faleceu, apenas com os familiares; (ii) na casa funerária, com exposição parcial do corpo, por, no máximo, duas horas; (iii) na igreja, antes do funeral, numa sala à parte, também com exposição parcial do corpo. O funeral, geralmente, no Canadá, é na casa funerária, ou, às vezes, na igreja. Contudo, um dos episódios narrados revelou o cemitério como um espaço onde se realizam todos os eventos pós-morte, aproximando-se, assim, dos rituais no Brasil: 


\section{14 (BR), L. 119-127}

No cemitério, tem uma área planejada, um local para a recepção dos convidados com salas separadas. Uma sala fechada com acesso por uma porta onde o corpo fica no caixão, e quem quiser velar ali, então, o caixão é aberto, e quem escolher entrar lá e olhar... quem não quer ver não entra na sala e fica em outra sala comum. Dali, as pessoas são encaminhadas para a capela por um corredor de acesso e, na capela, o caixão foi trazido fechado com flores em cima. Depois da liturgia, os homens da família, com a ajuda de funcionários muito bem vestidos de terno e gravata, levaram o caixão com o corpo pra o carro fúnebre. E todas as pessoas acompanharam o cortejo, em seus carros, até o local do enterro. Tudo isso dentro do cemitério. (sic)

$\mathrm{Na}$ Noruega, geralmente, o funeral é na igreja, inclusive, de famílias não religiosas. Neste caso, a cerimônia pode não seguir os rituais religiosos e ser presidida por uma pessoa leiga. Como variações regionais mais marcantes, os dados apresentaram velórios em casa das famílias, em cidadezinhas do interior, aproximando o país nórdico do nosso. Já no Brasil, no que se refere à religião católica, raramente, apenas em caso de religiosos, por exemplo, bispo, padre, diáconos, freiras, o velório e/ou funeral realiza(m)-se na igreja. Em relação a pessoas públicas, em comum às três nações, esses eventos podem ser realizados em teatros, ou salões de prédios públicos.

Os depoimentos seguintes apontam espaços distintos para velório nos três países:

\section{16 (BR/NO), L. 103}

$\mathrm{O}$ último foi enterro, não foi cremação. $\mathrm{O}$ velório foi no $2^{\circ}$ andar, no Cemitério do Caju (...) (sic) [BR]

\section{12 (BR), L.12-13}

Uma hora, duas horas antes do culto, abre-se o caixão, e as famílias vão lá ficarem juntos naquele tempo antes do culto. Depois, fecha-se o caixão, e se começa, então, a cerimônia. (sic) [casa funerária - CA]

\section{07 (NO), L. 168-171}

Eu e minha família, todo mundo foi no lar para idosos, no dia que ela faleceu, e demos nosso último tchau. Aí, falamos alguma coisa. Lembro que minha mãe 
falou uma coisa pra minha vó, umas palavras pra dizer adeus pra ela. (sic) [velório - NO]

\section{08 (NO), L. 27-30}

As pessoas lá, do hospital onde ela morava, tinha preparado ela, pra gente ver ela mais uma vez. Aí, foi só eu e meu irmão e uma irmã menor. Foi a primeira vez que, assim, a gente tinha um familiar próximo [avó] pra ver. Deu vontade de beijar, mas a gente não sabia se podia. (sic) [velório - NO]

No final desse último relato, está outra variação regional subjetiva, enquanto muitos dados revelaram que beijar o corpo é impraticável, a informante 08 (NO) sentiu vontade de fazê-lo, mas não sabia se podia, provavelmente, por nunca ter visto alguém se comportar assim. Mais adiante, quando falarmos de espaço pessoal, há dados que comprovam a não prática do beijo na Noruega e no Canadá, no que se refere aos eventos aqui tratados.

No Canadá e na Noruega, há um acontecimento que não é comum no Brasil, a celebração da vida, que ocorre após o funeral, com comidas, bebidas, discursos sobre o falecido e boas recordações. Nessa comemoração, familiares e amigos se reúnem, para que a alegria substitua a tristeza. Há pessoas que fazem mais de uma celebração, reunindo grupos diferentes. Pelos dados, esse evento pode realizar-se em casa dos familiares ou de amigos, salão na casa funerária, salão na igreja, ou mesmo num restaurante, casa de festas, hotel de luxo, onde quer que familiares e amigos, ou só familiares, ou todos os que compareceram ao funeral possam participar. Como sempre, há uma grande variação, dependendo da região e da religião do informante. Na Noruega, esses espaços são mais restritos, não é comum ser num salão da funerária, muito menos em um hotel. Em geral, são escolhidos salão da igreja, restaurante, casa da família e até um bar onde bebem o defunto. Essa expressão idiomática aproxima Noruega e Brasil, pois ela também é usada em nosso país. O dito sobre os países de cultura ativo-linear se comprova na sequência:

\section{12 (BR), L. 49-54}

A família mesmo contrata alguém, ou, às vezes, a própria funerária contrata alguém pra trazer os comes e bebes, e a família fica confraternizando lá [casa funerária], inclusive, muito descontraído também. Não é nada desesperador, ou não é nada muito triste depois. A recepção, você vê os familiares todos rindo, 
olhando as fotos da pessoa que morreu, até mesmo contando piadas, por um bom tempo, e falando coisas interessantes da pessoa que faleceu. (sic) [CA]

\section{15 (BR), L. 194-196}

(...) depois do funeral, durante aquela parte da comida, as pessoas se acalmam, relaxam, as pessoas vão embora bem menos emotivas, bem menos emocionadas, do que estavam durante a cerimônia. (sic) [CA]

\section{13 (BR), L. 14-16}

Eu fiz um pouco diferente do meu marido. Exatamente, porque eu sabia, eu fiz no Fact Club , fiz tudo bonito, memorial service, mas eu fiz uma cerimônia de uma despedida, celebrando a vida dele. [CA]

\section{18 (BR), L. 64-67}

No almoço [restaurante], continuaram as declarações, devia ter umas quinze mesas, cada uma com dez pessoas. Era bastante gente, e, aí, você ouvia alguém bater no copo trim, trim, trim. E todo mundo tinha que parar de comer, ficar quieto porque alguém tinha alguma coisa a falar. Não é triste. É emocionante, sabe? (sic) [NO]

\section{06 (NO), L. 26-30}

(...) depois da cerimônia [funeral], todo mundo que estava na igreja foi para o salão de festas da igreja. Isso quase sempre se faz, ou no salão da igreja, ou na casa da pessoa. (sic) $[\mathrm{NO}]$

\section{17 (BR), Q. 8}

Podem, também, ir pra um bar beber cerveja, o que eles chamam de beber o defunto. Então, falam sobre o morto, você faz memória. (sic) [NO]

$\mathrm{Na}$ Noruega, a maioria das mortes é por idade, e as pessoas idosas, em geral, falecem em instituições para idosos, casas confortáveis e amplas, com toda a assistência necessária. Esse espaço contempla o dizer de Lewis (Cf. 2.1.3), ao afirmar que os noruegueses gostam de espaços amplos e ventilados. Quanto ao amor às montanhas, identificado por ele, isso é comprovado por um dos e-mails em que a informante relata que as cinzas do marido foram jogadas nas montanhas, conforme era seu desejo. Ela fala também que ele havia programado o próprio funeral. Veja as palavras da viúva:

\section{E-mail 01 (NO)}

Para aqueles de vocês que lêem Norwegian eu colocar o anúncio em Aftenposten hoje. Helge tinha planejado seu funeral já há muito tempo e ele estará em seu espírito, sem a "interferência" religioso, com muita boa música e 
um encontro mais tarde com muito boa comida e vinho. O programa para o funeral vai conter muitas fotos e eu vou enviá-lo para você em uma ocasião posterior. Ele não queria uma sepultura, e suas cinzas serão espalhadas nas montanhas perto da cabine, em agosto. (sic)

Quanto ao espaço pessoal, os dois pesquisadores são confirmados no que se refere ao beijo. Todos os entrevistados foram unânimes em dizer que beijos em interações face a face é coisa de brasileiro. Quanto ao abraço, houve muitas variantes, nos países de cultura ativo-linear. Na hora dos cumprimentos, a grande parte dos canadenses e noruegueses se expressam só com palavras, ou com palavras e aperto de mãos, mas há os que se expressam com palavras e abraços e, dependendo da intimidade entre os interactantes e da pessoa que faleceu, com abraços silenciosos. Veja dados encontrados:

\section{09 (NO), L. 115-116}

Nos cumprimentos, tem aperto de mãos e palavras. Se você conhece a pessoa muito bem, tem abraços e palavras. Beijo, não. (sic)

\section{06 (NO), L. 62 a 64}

Só cumprimentam com aperto de mão, abraços só se for alguém muito, muito próximo, não é comum. O momento de abraços entre os familiares só em casa, em público não. Dizem minhas condolências, meus profundos sentimentos. (sic)

\section{12 (BR), L. $97-99$}

Geralmente, tem o aperto de mão e o abraço, apesar de que o canadense não é nem metade do que é o brasileiro, em termos de toque. $O$ canadense não é do toque, mas, na hora do evento do óbito, do funeral, então, existe o abraço. (sic)

\section{10 (NO), L. 105-108}

O abraço é bem comum. Homem não abraça homem, mas isso também está acabando. Há 20 anos, era meio difícil, agora é bem comum o abraço. Às vezes, dão a mão e um abraço ao mesmo tempo. Você dá a mão e sente se vai ser legal dar um abraço, ou não. O aperto de mão é a primeira tentativa, o teste. Às vezes, isso fica próximo demais. Beijos não tem. Isso é brasileiro.

\section{01 (CA), L. 14-16}

No Canadá, cumprimentamos a família enlutada de acordo com a proximidade do relacionamento. Aperto de mãos para pessoas estranhas e abraço para amigos próximos e familiares. 


\subsubsection{Espaços Ambíguos}

No que se refere ao espaço social ambíguo (Cf. 2.1.4.1.2), o corpus nos surpreendeu um pouco por não termos atentado, inicialmente, para as variações regionais existentes em todos os países. Em relação ao Brasil, os dados comprovaram o que já havíamos observado, ou seja, em caso de falecimento, capelas ou outros espaços físicos, reservados para a realização de velório, funeral, sepultamento, seja em hospital, igreja, casa funerária ou em cemitério - espaços caracterizados por relações de impessoalidade e de distanciamento - constituem espaços ambíguos, uma vez que, em geral, amigos e pessoas conhecidas comparecem a esses espaços em apoio à família enlutada, compartilhando sentimentos de amor, consideração, respeito, solidariedade e sofrimento, na intenção de aliviar, confortar um pouco a dor da família fragilizada por uma perda. Além desses, os eventos pós-morte e as relações interpessoais podem tornar-se espaços sociais ambíguos devido ao fato de as pessoas se expressarem por meio de lágrimas, mas também por gestos de carinho, afagos, abraços e beijos.

Fazemos aqui um parêntese para suplementar os dados colhidos em fonte primária dos informantes que colaboraram com esta pesquisa, por entendermos que os fatos citados corroboram esta proposta. Passamos a relatar a cobertura da morte e sepultamento de um cantor sertanejo, Cristiano Araújo, pela Rede Globo de Televisão, em 25/06/2015, época em que estávamos absolutamente imersas nas reflexões sobre o tema desta Dissertação. Portanto, foi impossível que as imagens veiculadas pela TV nos passassem despercebidas e, muito mais, que todo o movimento em torno dos preparativos para o funeral e o velório que se seguiu não se misturassem aos relatos lidos e analisados.

O jovem artista faleceu em acidente automobilístico, aos 29 anos, e seu corpo foi transladado em cortejo por sua cidade natal em dois momentos: primeiro, quando o corpo chegou a Goiânia e seguiu para a Câmara Minicipal onde ficou exposto para as últimas homenagens de familiares, amigos e fãs; depois, quando dali saiu para o Cemitério Jardim das Palmeiras, na mesma cidade, em um caminhão do Corpo de Bombeiros. Uma multidão de fãs se aglomerou nas principais avenidas da cidade para ver a passagem do ídolo. Era evidente a comoção das pessoas que diziam: "Vai com Deus". Na hora do sepultamento, um cordão de seguranças cercou a sepultura para que os coveiros pudessem iniciar os 
procedimentos. Apesar de uma morte repentina, devido a um acidente de carro, quando o cantor, no auge da vida e do sucesso, voltava de um show, não houve desespero nem gritos. Muitos se expressaram pelas lágrimas, principalmente o pai que, quando o caixão ia ser baixado, sentou-se à beira da cova e continuou chorando silenciosamente. Assessores do falecido agacharam-se e apoiaram o homem, que insistia em aproveitar o último momento de intimidade com o filho. Houve um respeitoso silêncio durante o enterramento, e aquela multidão parecia compartilhar da dor da família enlutada como se dela fizesse parte. Naquele momento de despedida, lembramo-nos das palavras de Rubem Alves (2003) em um de seus contos: "a morte é onde mora a saudade".

Aquele espaço público se travestiu de lar do rapaz e as milhares de pessoas presentes, sua família: a família goiana se deixou ver pelas janelas em que transformaram as lentes das câmeras de TV no seu momento mais íntimo de dor. Ali, a linha tênue entre o público e o privado ficou definitivamente embaçada.

Embora possa parecer, essa solidariedade não se deve apenas ao fato de se tratar da morte de um ídolo. Em nossos dados, há exemplos de velório de pessoas humildes também caracterizando o espaço ambíguo, quando a rua é englobada pela casa que recebe estranhos como se fossem agregados.

De volta à análise dos textos transcritos na primeira fase da pesquisa, encontramos o relato da informante 14 que, justamente, traçando um painel dos rituais pós-morte na cidade de onde chegavam as imagens assistidas por todo o Brasil naquele dia, vinha ao encontro de nossas observações pessoais. São dela as palavras a seguir:

\section{14 (BR), L. 5-18}

Em Goiânia, (...) o pessoal expressa os sentimentos de uma forma muito forte e muito audível. É muito emocional, é muito tocante, com certeza. (...) o corpo fica ali exposto durante um dia inteiro, uma noite inteira, e as pessoas ali velando um cadáver. (...) o mais interessante desse ritual, no Brasil, é que até mesmo quem não conhece o morto vai. Assim, se tem um funeral ali, e o pessoal tá passando, "Ai, o que aconteceu, aí? Nossa, fulano sofreu um acidente? Foi morte matada, ou morte morrida?”. A pessoa já entra e já se solidariza com a família do morto, com as pessoas que estiverem ali e acontece aquela aglomeração de gente até desconhecida, ou amigos do amigo, do amigo, do amigo que vem. Os funerais, em Goiânia, nas áreas mais pobres do país, geralmente, é na casa da pessoa falecida, ou da mãe do falecido. (sic) 
A mesma informante faz outro relato que caracteriza, a partir do contato físico, as relações interpessoais como espaço social ambíguo:

\section{14 (BR), L. 43-45}

Geralmente, em funerais, a gente é bem afetiva, dá um abraço, oferece o ombro praquela pessoa chorar, escuta o que a pessoa quer dizer, se a pessoa quer desabafar. Tem bastante contato físico. Bastante contato físico mesmo. (sic)

Nesses dados, está contido o motivo pelo qual todas aquelas pessoas, em vez de fazerem um tumulto, como pensam os depoentes estrangeiros de nós, proporcionaram momentos de um profundo e eloquente silêncio.

A impressão que se tem é que houve ali uma analogia ao modo como as famílias recebem aqueles que chegam para velar com eles seus mortos: acolhem em seu lar, de portas abertas, toda e qualquer pessoa que se sinta motivada a prestar homenagens ao falalecido e solidariedade aos enlutados. Esse comportamento que se sobrepõe ao impessoal ainda pode ser visto em outras cidades do interior do Brasil, e foi o que motivou o estranhamento de um norueguês, ao se deparar com o espaço ambíguo do velório realizado em casa, como o relatado anterior da informante 14. Com portas e janelas abertas durante toda a noite, seguindo normas de recepção, a família enlutada demonstra respeito pela pessoa da visita e recebe, em casa, o parente, o estranho e até mesmo o estrangeiro.

Os dados a seguir revelam o estranhamento do norueguês, ao deparar-se com o espaço ambíguo do velório realizado em casa em outro estado do Brasil:

\section{09 (NO), L. 119-121}

No Brasil, é aquele estresse, aquele cansaço. Principalmente, em Tocantins. Aquele mundo de pessoa que vem e fica na sua casa, e você tem que gastar com comida e tudo. Na Noruega, é muito mais tranquilo. A pessoa tem a oportunidade de sofrer em paz.

Quanto ao Canadá e à Noruega, como variantes, houve dados revelando a existência de espaços ambíguos em algumas regiões desses países. Além dos espaços ambíguos detectados no Brasil, encontramos o espaço ambíguo celebração da vida. Por outro lado, na maioria das vezes, os dados apontaram, em todos os espaços públicos, ausência de espaços ambíguos, quando canadenses e 
noruegueses apenas cumpriram uma convenção social, de forma aparentemente fria e de emoção controlada.

Entretanto, nesses dois países de cultura ativo-linear, identificamos um espaço ambíguo no que se refere às relações interpessoais, caracterizado pela ausência de distanciamento entre família enlutada e celebrante religioso, mesmo quando não se conheciam. Isso se comprova nos seguintes episódios:

\section{12 (BR), L. 74-82}

Conhecendo ou não a pessoa falecida, eu sempre chamo a família pra vir pro meu escritório, na igreja, e a gente tem uma reunião. Eu aprendo mais algumas coisas sobre a pessoa, às vezes, eu não conhecia de maneira nenhuma, e também sobre os detalhes como vai ser a cerimônia. Então, essa reunião é muito importante. (...) Sempre sou convidado pros comes e bebes e faço questão de estar lá. É uma forma de marcar presença e dizer que a igreja se importa com eles. E, normalmente, o que a gente faz, também, é, após um tempinho, ligar pra família pra saber como eles estão e marcar uma visita, pra ver como está a viúva, o viúvo. (sic) [CA]

\section{07 (NO), L. 91-93}

É a funerária que avisa o padre. Aí, o padre liga pra família e pergunta que horas e que dia pode encontrar com a família. Aí, todo mundo se junta e fala histórias da pessoa que faleceu. (sic) [NO]

\section{10 (NO), L. 83-87}

Quase sempre vou pra casa da família e pergunto sobre a vida do morto. Se eles preferem, podem ir ao meu escritório, mas prefiro ir à casa deles. (...) Fica mais próximo. A gente toma café, vejo fotos. Depois de escrever o discurso, às vezes, eu envio pelo e-mail pra família pra eu ter cem por cento de certeza que eles querem que o discurso vai ser assim. (sic) [NO]

Nesses depoimentos, percebemos que, além da preocupação com a família da pessoa falecida, os religiosos respeitam a vontade deles. Não fazem um discurso convencional, mas têm o cuidado de dizer palavras sobre o ente querido que agradem e toquem o coração dos familiares. Isso é um gesto de carinho que alenta os corações fragilizados.

Esse funeral bonito, no dizer de nossos informantes, não faz parte de nossa cultura. Nos dois países de cultura ativo-linear, celebra-se a vida da pessoa falecida e não a morte; o foco do velório e das demais cerimônias está nos momentos felizes que 
compartilharam. No Brasil, além de se celebrar a morte, nem há tempo para os preparativos desses rituais. Isso fica evidente nos relatos a seguir:

I 09 (NO), L. 69-72

Depois [do velório] ficam uns dias e vem o dia do funeral. É aquela questão que você tem tempo pra planejar, né? Tem o músico, os hinos que a gente utiliza. Não é coincidência, é o que minha mãe gostava. A gente senta junto, os irmãos escolhendo juntos, e tem alguns tipos para o funeral. Foi um momento muito legal, a gente sentou junto, tocou violão, lotou a igreja. (sic)

\section{15 (BR), L. 80-85}

O tempo entre a morte e o funeral também dá a oportunidade da preparação tanto para a família quanto para os convidados. Talvez seja por isso que as pessoas vão um pouco mais bem-arrumadas, tiveram tempo de se programar, já sabem com antecedência a hora, enquanto aqui, no Brasil, o que acontece em 24 horas, normalmente, é de correria. As pessoas vão, em meio a uma coisa e outra, sai do trabalho rápido, passa no velório. (sic)

\section{05 (CA), Q. 15}

O tempo para o funeral, no Brasil, é chocante. É muito rápido, não dá tempo para a família se organizar, nem pras pessoas que moram longe chegar. (sic)

\subsubsection{A Esfera do Outro Mundo}

Em relação à esfera do outro mundo (Cf. 2.1.4.1.3), da forma como a trata DaMatta, os dados mostraram que, no Brasil, as pessoas levam mais tempo para esquecerem o ente querido. É possível dizer que essa esfera também é um espaço de significação social, em oposição ao mundo real, e que as distinções encontradas nesses dois espaços não são exclusivas, mas complementares. Isso pode ser observado em anúncios fúnebres como o da Figura 3 a seguir, coletado na seção Obituário do Jornal o Globo, de 16/05/2015, em que uma família inclui um filho, in memoriam, como um dos que convidavam para a cerimônia de despedida da mãe. 


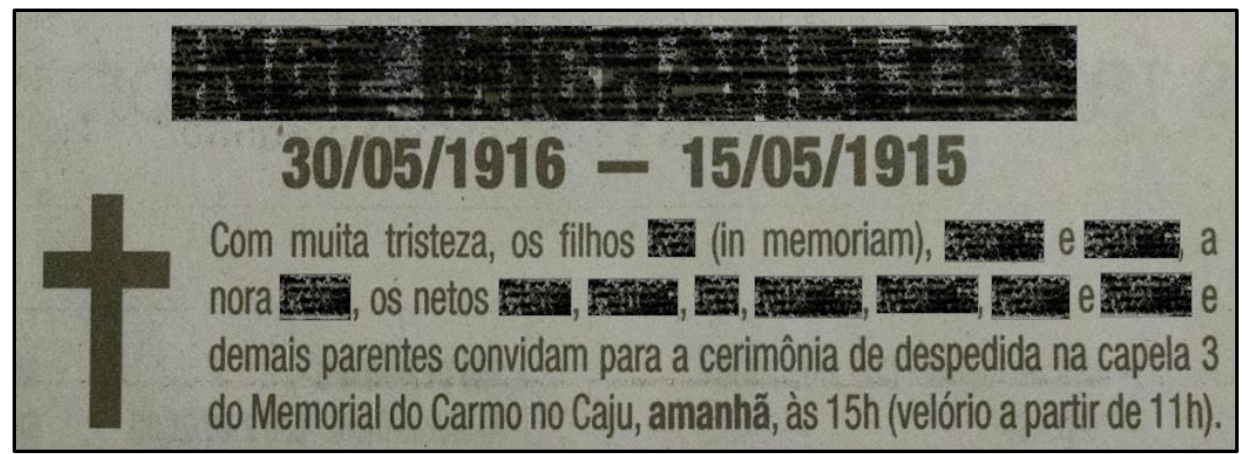

Figura 3 - Fac-símile - jornal O Globo - 16-05-2015

Em diferentes edições do mesmo jornal, há também anúncios em que, da mesma forma, o familiar, in memoriam, agradece as manifestações de pesar e convida para a Missa de Sétimo Dia ou a Missa de Mês. Outras maneiras de vínculo entre esses dois mundos são os agradecimentos in memoriam, aos entes queridos em livros, dissertações e teses, por exemplo, e as visitas ao cemitério em datas comemorativas. Para DaMatta, o espaço do outro mundo é um importante conjunto da identidade cultural brasileira, mas os dados revelaram que ele é levado em conta, também, nos outros dois países, onde os cemitérios são como parques floridos, e as pessoas vão conversar com seus mortos. Na Noruega, vão, também, passear e levar crianças para brincar. Por mais estranho que nos pareça, esse tipo de lazer faz parte das convenções sociais da cultura desse país como pode ser observado na sequência:

\section{17 (BR), L. 88-98/105-106}

(...) o cemitério aqui [NO] (...) É um jardim muito florido. É muuuuito bonito. Muita gente vai passear mesmo. Tem caminho pra passear. Eu ando muito mais descontraída aqui, pelo cemitério daqui que é todo aberto, não tem grade, não tem nada, do que ando no Brasil. Eu tenho horror de ir a cemitério no Brasil (...) Aqui, as pessoas vão sempre cuidar das flores. Tiram e plantam outras que levam. (...) Se o tempo está bonito, vamos lá, no cemitério. É uma coisa normal. Levam crianças, ninguém fica com medo. (sic)

O cemitério aqui (...) coloca só as urnas. A gente fala "Vou ver minha sogra". (sic)

\section{07 (NO), L. 178-182}

Aqui (...) pra algumas famílias é costume passar no cemitério pra visitar a família. Fala mesmo: "Vou visitar a minha vó". (...) minha melhor amiga, ela 
também perdeu o avô dela, ela já foi lá duas ou três vezes, e ele faleceu foi agora, no mês passado. (sic) [NO]

\section{09 (NO), Q. 14}

O pai de um amigo todos os dias vai falar com o filho que faleceu há seis anos.

DaMatta compara essas visitas às lápides a nossas casas no outro mundo (Cf. 2.1.4.1.1). Quanto às visitas agradáveis, isso ainda não faz parte da cultura do Brasil; somente nos últimos tempos tem-se observado um movimento de inserção de alguns cemitérios históricos nos roteiros turísticos, com guiamentos e eventos culturais como saraus de poesia e concertos musicais, a exemplo do que já existe em outros países, como o famoso cemitério da Recoleta, em Buenos Aires, na nossa vizinha Argentina.

Diante desses dados, conforme pode ocorrer com a casa ou com a rua, é possível que o outro mundo seja um importante elemento englobador de situações sociais, fazendo parte de um conjunto fundamental da identidade cultural de um país. Como exemplo, podemos citar, mais uma vez, as pessoas, na passagem do corpo do cantor sertanejo, em pleno estado de comoção, dizendo: "Vai com Deus"!

\subsubsection{Rituais de Passagem}

Os dados corroboram DaMatta (2.1.4.3), revelando que esses ritos fúnebres correspondem a momentos marcantes na vida da pessoa que sofre uma perda irreparável. O sofrimento, naturalmente, é o mesmo nos três países; o modo de expressá-lo é que difere por razões culturais.

A religião marca esse ritual de passagem funeral nas três culturas e determina o como a cerimônia deve acontecer. São as convenções estabelecidas pelas Igrejas, e aceitas e seguidas pelas sociedades. Os representantes desse ritual são os elementos corpo e caixão: no caso do Brasil, a urna permanece aberta até a hora do sepultamento ou cremação; no Canadá e na Noruega, o caixão fica lacrado; e, nos três países, ocupa, simbolicamente, o centro do espaço. No Canadá, há casos em que o corpo já foi cremado, mas a urna ainda assim está lá no centro, como ícone principal do ritual. 
Além dos discursos peculiares a essa cerimônia e das flores, se a pessoa for cristã, há o crucifixo e as velas. $\mathrm{Na}$ sequência, estão as informações observadas nos dados.

\section{10 (NO), L. 63-74/101-104}

Na Noruega, no dia do funeral, (...) geralmente, tem três hinos. Muitas vezes, tem uma solista que toca músicas diferentes, além das que a comunidade canta. Começamos sempre com um discurso sobre a vida da pessoa. Em geral, eu faço esse discurso, mas pergunto sempre antes se algum familiar ou amigo quer falar alguma coisa, que fica mais pessoal. (...) Primeiro, o discurso, depois, cantamos, tem três leituras da bíblia e, depois, o discurso que é mais bíblico. Eu procuro relacionar os dois discursos, que o discurso bíblico fica ligado com a pessoa que tá morta; tem a ver com a vida dela ou dele. (sic)

É mais comum agora mostrar sentimentos do que alguns anos atrás. Isso depende de uma família para outra. Antes, eles tomavam remédio pra ficar mais fortes. Na hora de falar alguma coisa sobre mãe, pai, avós, eles choram um pouquinho e recomeçam. Você vê que não é tão fácil pra eles. (sic)

\section{12 (BR), L. 14-18; 37-45}

Existem diferenças entre igrejas, como os outros pastores fazem, né? Nós não costumamos usar muito o que chamamos de eologia que é o tributo, que as pessoas vão lá na frente falar da pessoa que faleceu. Nós não costumamos incorporar isso dentro do culto. Nós fazemos isso depois, após a cerimônia, quando há a recepção com comes e bebes com todos os presentes. (sic) [CA]

Tanto no velório, que é bem curtinho em relação ao Brasil, como no culto em si, na cerimônia e, também, no sepultamento. (...) Eu vejo menos emoção do que no Brasil. O canadense é menos emotivo. Não sei se a gente pode chamar de mais frio (...) Até mesmo o choro da viúva, do viúvo, ou dos filhos é bem contido, controlado. $\mathrm{O}$ canadense, ele não mostra muita emoção. Às vezes, a gente vê lágrimas, mas não é aquele pranto desesperado que a gente vê no Brasil. (sic)

Em nosso país, diferenciando-se dos países de cultura ativo-linear em estudo, todos os eventos - o velório, o funeral e o sepultamento -, como já informado, costumam acontecer em 24 horas e, em geral, essas cerimônias ocorrem no mesmo lugar, ou seja, no cemitério, onde não existe mais velório durante toda a noite, como no passado. Não por razões culturais, mas por questões de falta de segurança pública. Se a pessoa for enterrada no dia seguinte, a família só fica no velório até 18 horas, quando o cemitério fecha. Esse aspecto social que 
interfere diretamente na manutenção dos ritos ganhará relevo adiante, na Conclusão. Nas igrejas católicas, pelo menos no Rio de Janeiro, normalmente, não se celebra mais esse tipo de cerimônia. Os cariocas que professam essa religião têm, nas secretarias dos cemitérios, a Pastoral da Esperança, composta por leigos que se oferecem para fazer orações e encomendarem o corpo. Contudo, há igrejas evangélicas onde o velório dura a noite toda, como já se disse ocorrer em cidades do interior em que casas ficam abertas dia e noite.

Em oposição aos dois países de cultura ativo-linear, no Brasil, não há a preparação do funeral de acordo com o agendamento da família e da funerária. Devido a isso, o sepultamento imediato à morte, a ausência de um gerente da casa funerária vestido de terno preto, orientando as pessoas presentes no cemitério, e de um folheto com a programação, a falta de muitos discursos pessoais em homenagem ao morto e a não realização da celebração da vida podem causar estranhamento a canadenses e noruegueses, ou até mesmo chocá-los. Isso se confirma no episódio narrado a seguir:

\section{01 (CA), L. 5-11}

O que mais me chocou, no funeral, no Brasil, foi que ele se realizou dentro de 24-30 horas, um tempo muito curto. Não houve comida nem recepção. Os discursos foram muito curtos e não muito pessoais. Depois do enterro, sem saber o que iria acontecer, o que fazer, minha filha e eu esperamos para ver se alguém ia falar com a gente, dizer qual seria o próximo passo. Senti a incerteza sobre o processo, medo de me comportar de forma inadequada e interromper esse tempo sagrado para a família.

Por comparação, o canadense, dependendo da região, pode usar expressões conotativas, mas geralmente são diretivos, cumprimentando-se de forma formal, com aperto de mãos e palavras denotativas. Vestem-se elegantemente, os homens de terno preto e camisa branca. As mulheres, em geral, usam cores sóbrias, embora nos dados tenhamos encontrado uma viúva que estava com um tailler vermelho na celebração da vida, segundo relato da informante 13, linhas 3 e 4 . Como já referido anteriormente, esse evento centraliza os ritos fúnebres. Ele acontece após o sepultamento e é a expressão cultural canadense e norueguesa de se prestar uma grande homenagem ao falecido. Nessa ocasião, há muitos discursos em desagravo ao morto, exibição de fotos, música, comida e bebidas. Alegremente, 
todos conversam falando sobre as coisas boas e engraçadas que aconteceram na vida do ente querido. Nesse ponto, canadenses e noruegueses se aproximam nas celebrações do rito de passagem fúnebre:

\section{06 (NO), L.40-44}

Esse planejamento é muito importante. Tudo tem que ficar bonito, a decoração, as toalhas... Depois da cerimônia religiosa, alguém faz um discurso e depois quem tem vontade conta os casos da vida do falecido, são histórias muito engraçadas, a gente morre de rir. Saímos do evento sem chorar, sorrindo. Lembrando que a pessoa viveu uma vida boa. Foi um momento muito bom em que a família estava junto. (sic)

\section{13 (BR), L. 64-71}

(...) E, como ele tinha background escocês, eu contratei uma pessoa que tocasse aquela gaita de fole, vestida de escocês. Aí, a família entra. Eu chamei a família toda, escolhi quem é que ia falar (...) Eu escrevi uma poesia que falei por último, a filha também quis falar, e mais alguma pessoa, algum estudante dele que quisesse falar. (...) Mesas de comidas com coquetel, bebidas... E celebramos a vida dele. Minhas amigas prepararam um powerpoint com as fotos dele e da família, todo mundo junto, com a música Garota de Ipanema. (...) é muito alegre. Não tem ninguém chorando. (sic) (CA)

\section{09 (NO), Q. 8}

Entre jovens, pode fazer festa, depois do sepultamento, num bar. Chama a cerveja funerária. Somos melhores pra beber do que pra comer. A gente fecha aquele lugar e só bebe. Isso não é junto com a família. É só os jovens mesmo. Quando eu era jovem, perdi um amigo, e fomos beber num bar, tocando as músicas da banda dele.

A partir dessa celebração, a família norueguesa e a canadense, em geral, quando se trata de morte por velhice ou por câncer, passam a viver sem ficar remoendo o passado. Obviamente, devido variações regionais, encontramos dados de informantes, dizendo que choraram nessa celebração, mas que a festa foi alegre.

Com relação à comunicação não verbal que se pode observar nesses espaços, os entrevistados de Canadá e Noruega revelaram que o vestuário dos participantes fala pelo respeito que entendem que a situação merece. Nesses países, homens de terno preto e camisa branca; mulheres, na maioria das regiões usam cores sóbrias. Apenas na região de Bergen (NO), elas costumam trajar uma roupa típica, só usada em funerais, no Dia da Independência, e no Natal. Os 
relatos a seguir revelam as variações regionais norueguesas na forma não verbal de comunicarem:

\section{18 (BR), L. 17-21}

As pessoas se vestem muito bem em comparação ao Brasil. Os homens vão de terno, as mulheres vão muito arrumadas. É comum usar uma roupa típica [bunad] que só mesmo no Natal e no dia 17 de maio, que é o dia da Noruega. Não usam nem em casamento. Cada mulher tem da sua região. É bem bonita, colorida e muito cara, tem muitos enfeites mesmo, bordados, colar. Elas se enfeitam muito mais. (sic)

\section{07 (NO), Q. 10}

Os homens usam terno preto, e as mulheres, roupa preta, pode ser casual, mas preta. Em Állesund, a roupa típica, bunad, só é usada no dia 17 de maio, independência da Noruega, crisma e batizamento. (sic)

Nós brasileiros, na maneira de nos vestirmos, usamos roupas informais, sem brilhos ou adereços espalhafatosos, apenas tomamos cuidado de não comunicarmos desrespeito, por mera convenção social. No Brasil, os dados levantados para este estudo não permitem fazer afirmações sobre um código cultural expresso pelas roupas. Pelo que se lê nos relatos sobre os rituais em nosso país, nas entrevistas, os informantes não deram nenhum destaque ao vestuário.

O senso comum, no entanto, nos permite dizer que, mais uma vez sendo determinado pela religião, em algumas circunstâncias específicas, em que o morto professa uma fé em que a vestimenta seja iconográfica, como no caso do espiritismo, tanto ele como os participantes da cerimônia vestem branco.

Ainda tratando os dados, pela ótica da comunicação não verbal, tanto no Canadá quanto na Noruega há também exposição de fotos, músicas religiosas e não religiosas. Há famílias que contratam músicos e cantores, outras usam uma gravação. Nessa cerimônia, todos ficam em silêncio, ouvindo o discurso da vez.

Quanto à ornamentação dos funerais, há em comum entre Brasil, Canadá e Noruega as flores e, se a pessoa for cristã, as velas. No Canadá, em geral, não se usam coroas de flores, só em algumas regiões e em caso de sepultamento. No Brasil e na Noruega, elas são usadas. Nos dois países de cultura ativo-linear, as flores são colocadas no ambiente e sobre o caixão; no Brasil, em geral, o corpo é 
todo coberto por flores, ficando apenas o rosto de fora. Isso choca um pouco o estrangeiro.

Quando divulgam a morte no jornal, tanto no Canadá quanto na Noruega, é comum pedirem para que, em vez de enviarem flores, façam uma doação para alguma instituição. Em um dos dados da Noruega, fornecido pela informante 17 (L. 35-40), foi sugerido o pagamento de uma viagem para a família enlutada. Isso se deve ao fato de, nesses países, considerarem um desperdício o que se gasta com esses elementos ritualísticos, como já exemplificado no item 4.1.1 pela voz do informante 02 (L.64-68).

Por fim, todos os relatos sobre os rituais funerais citam que há bastantes discursos, formais ou informais, proferidos por celebrantes religiosos, parentes e amigos, mas não apareceu nenhum exemplo em nosso corpus. Nas três culturas, como não poderia deixar de ser, as palavras ditas com a função primeira de homenagear o morto e o sepultamento em si causam comoção, e as palavras servem mais como um gesto de consolo para os que sofrem aquele momento. Os discursos, conforme os dados, constituem o ponto alto do cerimonial e antecedem imediatamente o momento em que os presentes vão se despedir do falecido.

\subsection{Convencionalidade e Linguagem}

Tendo em vista as considerações sobre a linguagem aqui refletidas e o pensamento de Tagnin (Cf. 2.2.1.2) de que convenção social é "qualquer dos usos ou costumes sociais estabelecidos, de tácita aceitação pelos indivíduos de uma comunidade, que incluem regras de boa educação, de boa conduta", foram constatados valores culturais e hábitos comportamentais intrínsecos às sociedades brasileira, canadense e norueguesa; e buscou-se comprovar a importância dos contextos de situação e de cultura na atribuição de sentidos a enunciados que exteriorizam sentimentos pessoais numa interação face a face.

A partir daqui, este trabalho assume o princípio de Tagnin (Cf. 2.2.1.2) de que a ideia de convenção pode ser aplicada à língua, tanto no que diz respeito ao aspecto social, sabendo quando dizer algo em determinado evento, quanto no que concerne ao aspecto linguístico, sabendo como dizê-lo, ou seja, com que grau de formalidade ou informalidade, de transparência ou opacidade, sendo diretivo ou 
indiretivo no uso das expressões convencionais. Foram observados, nas três culturas, pontos convergentes e divergentes.

Dessa perspectiva, levando em conta os níveis semântico e pragmático, passa-se à análise da linguagem dos dados primários.

\subsubsection{Expressões Verbais}

As expressões convencionais sociais presentes no corpus dos depoimentos, colhidos nas entrevistas, são encontradas em blocos e estão intimamente relacionadas ao ritual de passagem morte, que exige certo comportamento social. Elas podem estar associadas a gírias, jargões ou contextos culturais específicos de certos grupos sociais que se distinguem pela classe, faixa etária, região, profissão ou outro tipo de afinidade. Umas ficam restritas ao local onde surgiram, como Dormir como um passarinho, citada por um brasileiro, enquanto outras perpetuam-se, sendo hoje usadas de forma mais abrangente, extrapolando o contexto original, ou seja, diacronicamente, é possível que percam a significação conotativa primária, ou a mantenham e ganhem outra(s) como será exemplificado mais adiante (Cf. 4.2.2) a partir de dados brasileiros. Nesses casos, na maioria das vezes, a origem histórica do seu significado se perde, ou fica limitada a um reduzido grupo de usuários da língua. Por isso, pessoas que não as conhecem podem não compreendê-las. Em nossa literatura, recuperando os conceitos de Tagnin (Cf. 2.2.1.5), algumas das expressões citadas classificam-se como convencionais, e outras como expressões idiomáticas, propriamente. Por seu turno, no dizer de Perini (Cf. 2.2.2), expressões citadas por informantes desta pesquisa como Saudades eternas de seus filhos e Meus sentimentos são expressões fixas que adquirem significados derivados de suas palavras componentes, sendo, portanto, convencionais sociais.

À luz desses autores mencionados, passa-se à análise das expressões em estudo como instrumentos culturais e sociais de comunicação e interação, com o intuito de verificar a identidade nacional de brasileiros, canadenses e noruegueses, proposta por Lewis conforme anunciado no início deste capítulo. 


\subsubsection{Expressões Convencionais}

Considerando os aspectos linguísticos - apesar de o Brasil ser um país de cultura indiretiva e os outros dois, de cultura diretiva -, na interação face a face, no que concerne ao fato social em foco, há dados indicadores de que, em determinadas regiões, os três países se aproximam.

Analisando as expressões convencionais, ou seja, as de sentido transparente, como era de se esperar, percebe-se que, nos países diretivos, esse tipo de expressão é mais usado do que no Brasil, onde são mais presentes as expressões idiomáticas. Contudo, isso depende das variações regionais existentes em cada uma das três nações. Identificamos quatro grupos de expressões as quais produzem o efeito de ou são usadas com o objetivo de: (i) atenuar a comunicação da morte; (ii) comunicar a morte de forma grosseira e desrespeitosa; (iii) cumprimentar ou encorajar a família enlutada; e (iv) expressar sentimentos em faixas de coroas de flores.

Na sequência, para que a exposição dos grupos fique mais didática, são apresentados três quadros, recortes adaptados de um quadro maior (Apêndice 04), conforme mencionado na Metodologia. A seguir, o Quadro 4 apresenta as expressões convencionais transparentes.

Quadro 4 - Expressões convencionais A

\begin{tabular}{|c|c|c|}
\hline \multirow{2}{*}{ Países } & \multicolumn{2}{|c|}{ Modos de se comunicar a morte } \\
\hline & $\begin{array}{l}\text { Atitude diplomática } \\
\text { Eufemismo }\end{array}$ & $\begin{array}{c}\text { Atitude de enfrentamento } \\
\text { Disfemismo }\end{array}$ \\
\hline Brasil & $\begin{array}{l}\text { Fazer a passagem } \\
\text { Passar desta para melhor }\end{array}$ & $\begin{array}{l}\text { Ir pra debaixo da terra } \\
\text { Passar desta pra pior }\end{array}$ \\
\hline Canadá & $\begin{array}{l}\text { Acontecer um acidente fatal } \\
\text { Fazer a passagem } \\
\text { Ir para o outro lado } \\
\text { Passar para longe } \\
\text { Pass away = falecer } \\
\text { Ter uma boa morte }\end{array}$ & \\
\hline
\end{tabular}




\begin{tabular}{|l|l|l|}
\hline \multirow{4}{*}{ Noruega } & Dormir tranquilamente para sempre & \\
Dormir satisfeito de dias & Escolher deixar essa vida & \\
Já acabar & Não estar mais entre nós & \\
Não estar mais conosco & Passar para longe & \\
Pass away = falecer & \\
\hline
\end{tabular}

Observando esse quadro, para atenuar a comunicação da morte, verificamos que, nos três países, são utilizadas as palavras passar e passagem. A ideia de trânsito nelas contida contribui para a transparência das expressões, relacionando a vida física à espiritual. Ilustrando pontos de contato, informamos que brasileiros e canadenses usam Fazer a passagem, cada um em sua língua vernácula, enquanto canadenses e noruegueses empregam muito a expressão Pass away. Essa expressão é tão usada por eles que primeiro a citam no original para depois fazerem a tradução, que segundo os informantes, é falecer. Cabe registrar que houve entrevistado que fez uma tradução literal: Ir embora, Passar para longe. No país nórdico, para comunicar morte por velhice, usam-se os eufemismos, Dormir tranquilamente para sempre e Dormir satisfeito de dias. Nos outros dois, para esse caso, só foram encontradas expressões idiomáticas semanticamente próximas.

Empiricamente, um informante faz uso dos conceitos de diretividade e de indiretividade e percebe que a escolha lexical tem relação direta com o modo de ser aprendido pelos falantes em cada uma de suas culturas particulares. A esse respeito, ele comenta:

\section{18 (BR) L. 30}

Os noruegueses são muito mais diretos do que a gente, então, eles não usam eufemismos. Falam "faleceu", "morreu". Se morreu de acidente, é outra palavra. (sic)

As expressões grosseiras, de afrontamento, são raramente usadas; em geral, seu emprego limita-se para pessoas públicas como artistas ou políticos, por indivíduos que não pertencem ao círculo social do morto. Não são ditas diretamente a familiares ou amigos do falecido. Quanto aos canadenses e 
noruegueses, eles lidam de modo mais reverencial com a morte, sendo quase impossível usarem essas expressões fora do contexto assinalado. Prova disso é que, no rol dos dados coletados nas entrevistas, nenhum exemplo pode ser encontrado. Isso se comprova no relato:

\section{18 (BR) L. 34}

Aqui [NO], não conheço nenhuma expressão grosseira que indique que alguém morreu. Acho que não existe esse tipo de expressão. Eles são muito educados no trato com a palavra. Eles são diretos, não gostam de dar muita volta pra falar alguma coisa, mas não são grossos a esse ponto. A morte é uma coisa muito séria, né? (sic)

Em relação ao brasileiro, apesar de usualmente não lidar com a morte com tanta formalidade, o uso desse recurso estilístico também é muito restrito, utilizado mais para causar humor, ou transmitir uma carga emotiva. No Brasil, encontramos os exemplos Ir pra debaixo da terra e Passar desta pra pior. Percebemos, na última expressão, que há um elemento elíptico: vida. Retomando à morte do cantor sertanejo (CF. 4.1.2), não encontramos na mídia nenhum emprego desse tipo de expressão. A seguir, tomando-se as palavras de outro informante, pode-se inferir que há ausência de disfemismos em nosso país para se comunicar a morte de alguém.

\section{21 (BR), L. 30}

Com relação a termos desagradáveis, eu não posso testemunhar esse tipo de acontecimento. O mais próximo disso de que eu lembro foi uma situação assim também. Eu estava em um funeral por razões sociais, questões, assim, de trabalho, que as pessoas precisavam estar. E, até pra descontrair daquela tensão, as pessoas começam a fazer algumas piadas, começam a fazer algum tipo de comentário, não sei se pra aliviar a tensão, pra fugir da realidade, e acabam falando umas coisas assim como "a viúva não vai sentir tanto assim". Esse tipo de coisa, mas nada grosseiro. Eu nunca presenciei nada grosseiro com relação às pessoas. Só lembro da literatura. Eu, provavelmente, talvez, tenha a minha memória contaminada mesmo da literatura, onde são bastantes as expressões: "já foi tarde", "ainda bem que morreu". (sic)

No que se refere ao Canadá, o ponto de vista desta análise é comprovado em: 


\section{12 (BR), L. 116-118}

Existe muito respeito com relação à morte aqui. Não imagino um canadense usando expressões grosseiras em relação à morte. Eles não brincam com a questão de morte. O canadense é uma pessoa muito ética e muito respeitador. (sic)

Para abordar as expressões de cumprimento e as mensagens escritas nas faixas das coroas de flores, observe-se o Quadro 5.

Quadro 5 - Expressões convencionais B

\begin{tabular}{|c|c|c|}
\hline Países & $\begin{array}{c}\text { Expressões de cumprimentos e } \\
\text { de encorajamento }\end{array}$ & Expressões escritas nas faixas \\
\hline Brasil & $\begin{array}{l}\text { Conte conosco } \\
\text { Ele está bem ao lado do Pai } \\
\text { Meus pêsames } \\
\text { Meus sentimentos } \\
\text { Seja forte } \\
\text { Sinto muito }\end{array}$ & $\begin{array}{l}\text { Descanse em Paz } \\
\text { Homenagem dos colegas de tal } \\
\text { lugar } \\
\text { Nós amamos você } \\
\text { Nós sentimos sua falta } \\
\text { Saudades eternas de... } \\
\text { Obrigado por todo tempo bom } \\
\text { que passamos juntos } \\
\text { Obrigado por tudo }\end{array}$ \\
\hline Canadá & $\begin{array}{l}\text { Deus abençoe você e sua família } \\
\text { Que Deus dê paz a seus corações } \\
\text { Ele está em um lugar melhor } \\
\text { E palavras de simpatia, falando } \\
\text { sobre o morto, encorajando a } \\
\text { família } \\
\text { Ele está em paz } \\
\text { Meus sentimentos } \\
\text { Minha mais profunda simpatia } \\
\text { Minha simpatia } \\
\text { Minhas condolências } \\
\text { Que Deus esteja com você } \\
\text { Seja forte, minha querida } \\
\text { Sinto muito (por sua perda) } \\
\text { Vamos encontrá-lo no céu }\end{array}$ & $\begin{array}{l}\text { Nós amamos você } \\
\text { Nós sentimos sua falta }\end{array}$ \\
\hline Noruega & $\begin{array}{l}\text { Como sua mãe agora vai ficar? } \\
\text { Condoleiras } \\
\text { Condolências } \\
\text { Estamos muito sentidos } \\
\text { Eu não tenho o que dizer } \\
\text { Meus sentimentos } \\
\text { Minhas Condolências } \\
\text { Minhas Condoleiras } \\
\end{array}$ & $\begin{array}{l}\text { Nós amamos você } \\
\text { Nós sentimos sua falta } \\
\text { Obrigado por todo tempo bom } \\
\text { que passamos juntos } \\
\text { Obrigado por tudo }\end{array}$ \\
\hline
\end{tabular}




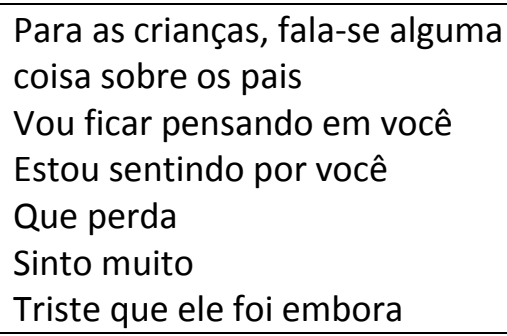

Quanto às expressões de cumprimentos e de encorajamento, há muitas semelhanças entre os três países. Inclusive, encontram-se usos comuns. Por exemplo, Minhas condolências, Sinto muito, Seja forte.

No Brasil e no Canadá, as expressões Meus pêsames e Minhas condolências sempre vêm acompanhadas pelo possessivo; na Noruega, há casos em que esse possessivo é omitido para agilizar os cumprimentos, provavelmente, devido ao grande número de pessoas no ritual. Por exemplo, segundo os informantes, há as variações Minhas condoleiras e Condoleiras, expressão só usada pelos noruegueses (Cf. Quadro 5).

Quanto às mensagens escritas nas faixas das coroas de flores, esse item não é comum aos funerais canadenses, que fazem uso de muitas flores e de pequenos arranjos, mas não de coroas. Contudo, houve um entrevistado canadense que disse que, em sua província, o item existe, e apontou como exemplos de dizeres utilizados Nós sentimos sua falta e Nós amamos você. Essas seriam mensagens padrão comuns aos três países, que cumprem formalidades, muitas vezes, escolhidas numa lista de frases oferecida pela floricultura. O Brasil e a Noruega convergem também no uso de outras expressões como Você está nos nossos corações e Obrigado por tudo. Curiosamente, no país nórdico, esta última só é utilizada no contexto de funeral. No Brasil, além desse uso, é empregada em qualquer situação de agradecimento, em contextos diversos.

Considerando as expressões de carinho público, verificamos mais um ponto de contato entre os três países, o que de certa forma vai de encontro ao pensamento de Lewis de que pessoas de culturas ativo-linear são frias e só as de cultura multiativa são emotivas e calorosas. 


\subsubsection{Expressões Idiomáticas}

A convencionalidade das expressões idiomáticas é observada na relação não motivada entre uma expressão e seu significado, ou seja, resgatando Tagnin (Cf. 2.2.1.4), “o significado da expressão toda não corresponde à somatória do significado de cada um de seus elementos”. No dizer de Perini (Cf. 2.2.2), elas são sequências de palavras "com significado próprio não derivado dos significados das palavras individuais". Desta forma, em geral, é muito difícil ou mesmo impossível traduzi-las para outras línguas, principalmente as que se afastam denotativamente do campo semântico a que pertence a palavra morrer. Como exemplo, as expressões levantadas na pesquisa em relação a esse assunto kick the bucket e bater as botas, empregadas no Canadá e no Brasil, respectivamente. O grau de opacidade dessas duas expressões é tamanho que elas podem não ser compreendidas nas várias regiões do país vernáculo, e muito menos por estrangeiros e crianças nativas. A tradução da expressão em inglês, chutar $o$ balde, para nós, brasileiros, também é uma expressão idiomática, só que, como tem origem num contexto cultural e linguístico distinto, seu significado é totalmente diferente, ou seja, significa ser negligente; perder o controle. Em inglês, conforme tradução do informante 03 , significa morrer.

Na sequência, apontamos, no Quadro 6, as expressões convencionais de sentido opaco, ou seja, as expressões idiomáticas, aceitas em algumas regiões dos três países no fato social aqui em análise.

Quadro 6 - Expressões idiomáticas

\begin{tabular}{|c|c|c|}
\hline \multirow[t]{2}{*}{ Países } & \multicolumn{2}{|c|}{ Modos de se comunicar a morte } \\
\hline & $\begin{array}{l}\text { Atitude diplomática } \\
\text { Eufemismo }\end{array}$ & $\begin{array}{c}\text { Atitude de enfrentamento } \\
\text { Disfemismo }\end{array}$ \\
\hline Brasil & $\begin{array}{l}\text { Acontecer uma fatalidade } \\
\text { Dormir como um passarinho } \\
\text { Ir morar com Deus } \\
\text { Ir para o céu }\end{array}$ & $\begin{array}{l}\text { Abotoar o paletó } \\
\text { Bater as botas } \\
\text { Comer capim pela raiz } \\
\text { Ir para a terra dos pés juntos } \\
\text { Ir pro Inferno } \\
\text { Ir pro quinto dos infernos } \\
\text { Vestir o paletó de madeira }\end{array}$ \\
\hline
\end{tabular}




\begin{tabular}{|l|l|l|}
\hline \multirow{2}{*}{ Canadá } & $\begin{array}{l}\text { Estar desaparecido } \\
\text { Ir embora } \\
\text { Ir para um lugar melhor } \\
\text { Ter tido uma vida boa } \\
\text { Ter sido uma pessoa fantástica }\end{array}$ & $\begin{array}{l}\text { Chutar o balde } \\
\text { Comprar a fazenda } \\
\text { Game over }\end{array}$ \\
\hline \multirow{2}{*}{ Noruega } & $\begin{array}{l}\text { Acabar o sofrimento } \\
\text { Deixar-nos } \\
\text { Dormir silenciosamente (pra dentro) } \\
\text { Ir para junto de Jesus } \\
\text { Ir embora } \\
\text { Ir-se } \\
\text { Já acabar } \\
\text { Não estar mais aqui } \\
\text { Passar pela última viagem } \\
\text { Ser processado pra glória }\end{array}$ & $\begin{array}{l}\text { Game over } \\
\text { Ir pro descampado último lugar pra fazer passe } \\
\text { Ir prom }\end{array}$ \\
\hline
\end{tabular}

Para atenuar a comunicação da morte, neste grupo, além de semelhanças, encontramos algumas particularidades. Em comum, há expressões relacionadas à religião e a fatos positivos como, no Brasil, Ir morar com Deus; no Canadá, Ir para um lugar melhor; e na Noruega, Ir para junto de Jesus. Em morte por acidente, há uma semelhança entre o Brasil e o Canadá: Aconteceu uma fatalidade e Aconteceu um acidente fatal, sendo que, em nosso país, o nível de abstração é maior. Das peculiaridades, observamos que, no Brasil, por velhice, há o emprego de Dormiu como um passarinho. O conectivo comparativo atribui a essa expressão uma singular ideia de intensidade.

No Canadá, costuma-se empregar o verbo no passado acrescido de um atributo positivo para consolar as crianças, por exemplo, Seu pai era uma pessoa fantástica ou Pelo menos ele teve uma vida boa. Enquanto nesse mesmo país, em geral, evita-se divulgar a causa da morte para a sociedade, principalmente, se a pessoa morreu por câncer ou por alguma complicação de AIDS, na Noruega, dependendo da causa mortis, há uma expressão específica para comunicá-la. A saber: Acabar o sofrimento, usada em caso de morte por câncer; Dormir silenciosamente (pra dentro), usada quando o falecido era muito idoso, ou havia uma perspectiva de morte; Escolher deixar essa vida/ Deixar-nos, usadas em caso de morte por suicídio. Interessante observar que, nesse caso, o sujeito é agente. Cabe observar que, tanto no Brasil quanto na Noruega, no caso de morte por velhice, ameniza-se a expressão com o verbo dormir - como se a pessoa tivesse 
apenas se desligado do mundo externo e estivesse em estado de sono, chegando à tranquilidade e felicidade do sonho, ao contrário do que acontece quando se usam os verbos morrer e falecer, por exemplo. Alguns noruegueses dizem para as crianças: Agora, ela tá dormindo para sempre. Quebrando as expectativas, na Noruega, apesar de o país oferecer um excelente padrão de vida, há um considerado índice de suicídios. A esse respeito, uma informante declara:

\section{20 (BR), Q. 3}

Não entendo por que o índice de suicídio aqui é tão alto. Ainda vou conversar com uma psicóloga para tentar entender. Eles têm tudo muito fácil. Você tem um sistema social muito forte. Se você perdeu seu emprego, durante dois anos, você recebe seu salário integral. Se você ficar doente e precisar de algum apoio, para pagar o aluguel, o governo vai pagar pra você. Noutro dia, uma pessoa se jogou na frente do trem. Isso acontece sempre, você está indo trabalhar e, de repente, tudo para porque alguém se suicidou. (sic)

\section{16 (BR), Q. 1}

Os noruegueses se suicidam de tédio. A vida lá é muito fácil. Se você não conseguir, o governo te dá. Falta motivação. (sic)

Quanto às expressões grosseiras, politicamente incorretas e raramente usadas, como foi esclarecido no grupo (ii) do item imediatamente anterior, o Brasil, provavelmente, pelo fato de aqui se usar uma linguagem coloquial permeada por recursos de imagens oriundos de sua subjetividade, criatividade e herança cultural, possui o maior número desse tipo de expressão. Destacamos $I r$ pro inferno e Ir pro quinto dos infernos por portarem duplo sentido conotativo, isto é, essas expressões foram criadas com os significados pejorativos de ir para longe e ir para muito longe, respectivamente. Hoje, convencionalmente, além de conservarem o sentido original, dependendo do referente, podem significar também morrer (Cf. 4.2.1). A acepção atual, provavelmente, corrobora o argumento de Tagnin (Cf. 2.2.1.3-B) quanto a que, na "cultura ocidental, por exemplo, tudo que é 'para cima' é considerado bom, enquanto o que for 'para baixo' é mau”. Compreendendo que, metaforicamente, em oposição ao céu, o inferno fica para baixo, as duas expressões idiomáticas são apresentadas como disfemismo (Cf. 2.2.1.3-B) para o verbo morrer. No Canadá, foram encontradas Chutar o balde e Game over. A segunda, também usada na Noruega, é 
pouquíssimas vezes empregada; a maioria dos informantes a desconhece. Passou a ser usada bem recentemente, mais pelos jovens, por influência de filmes americanos. Esse tipo de expressão pode apontar uma representação figurada da realidade como um meio de caracterização pitoresca, no desejo de despertar o cômico, ou transmitir um sentimento de desdém ou raiva. Em Oslo, as pessoas são mais diretivas, empregam a palavra morrer. Não usam eufemismo nem disfemismo. Isso se comprova em:

\section{16 (BR/NO), L. 66-67}

Não usam expressões que suavizam, falam "morreu" mesmo. (sic)

No que se refere às expressões de cumprimentos e de encorajamento, há poucas expressões idiomáticas. Do modo como entende Perini (Cf. 2.2.2), no Brasil, encontramos Ele está bem ao lado do Pai; no Canadá, Vamos encontrá-lo no céu; e, na Noruega, comprovando a diretividade de sua cultura, nenhuma foi identificada.

Essa escassez de expressões de sentido opaco pode ser atribuída à delicadeza do contexto de situação e à cultura do respeito à dor da família enlutada, tal como aprendemos com DaMatta (Cf. 2.1.4.3) e Tagnin (Cf. 2.2.1.2), por ser mesmo um momento em que não se sabe o que dizer. Dessa forma, constata-se mais um ponto comum entre Brasil e Canadá, e uma semelhança entre os três.

No que se refere às mensagens escritas nas faixas das coroas de flores, no Brasil e na Noruega, não foi citada na pesquisa nenhuma expressão idiomática. Quanto ao Canadá, como dito anteriormente, em geral, não se usam coroas de flores em funerais, e o informante da província onde há essa prática também não lembrou nenhuma para apresentar.

Com base na presente análise, constatamos que essas expressões deslizam de um nível cuja decodificação semântica é mais fácil, como Comer capim pela raiz (BR), para outro fortemente conotativo, como Abotoar o paletó (BR). Esta última é de difícil decodificação, pois todos os seus vocábulos estão semanticamente esvaziados. Ir para um lugar melhor (CA) ou Não estar mais aqui (NO) são de fácil decodificação, pois os elementos semanticamente 
presentes, de valor denotativo, estão associados a componentes semanticamente ausentes, de valor conotativo. Pode-se dizer que há expressões cuja transparência ou opacidade é tão tênue que a determinação entre expressão convencional ou expressão idiomática fica escorregadia. É o caso de Ir morar com Deus, que a princípio parece ser transparente, entretanto a facilidade de sua decodificação não está nos seus elementos semanticamente presentes, mas sim, na alta aceitabilidade e no uso da expressão que extrapola os limites de uma nação, tanto que ocorre nos três países aqui comparados, principalmente, em famílias cristãs. Já a expressão $I r$ pra debaixo da terra, que também pode causar dúvida quanto à sua transparência, adquire significado derivado de suas palavras componentes, assim sendo de nível fracamente conotativo.

Considerando ainda no âmbito da sutileza, nos dados brasileiros e canadenses, foram encontradas, respectivamente, as expressões Acontecer uma fatalidade e Acontecer um acidente fatal, ambas com o sentido de morrer. Conforme Perini, trata-se de duas expressões fixas homônimas de dois sintagmas normais (Cf. 2.2.2.), uma vez que, como sintagmas, fatalidade denota catástrofe, desgraça; e fatal denota grave, inevitável, nefasto. Constata-se uma forte relação semântica entre os sintagmas e as expressões a eles relacionadas, mas parece que há na primeira um nível conotativo mais forte do que na segunda, assim, a usada no Brasil foi elencada como expressão idiomática; e a citada pelos canadenses, como expressão convencional.

Fazendo um paralelo desse "deslizar" semântico das expressões aqui em estudo, com as ponderações de Perini sobre as expressões metafóricas (Cf. 2.2.2.1), infere-se que, na concepção do autor, Ir pra debaixo da terra é uma expressão metafórica, pois pode ser interpretada em seus próprios termos. Por outro lado, Ir morar com Deus, como toda expressão idiomática, não é uma expressão metafórica, pois não há uma associação semântica entre seus elementos presentes, de valor denotativo, com seu componente ausente, de valor conotativo. Seu significado está na memória dos que a usam. 


\subsubsection{Suavização, Afrontamento, Realidade}

Além das expressões mencionadas nos dois itens imediatamente anteriores, apontamos, no Quadro a seguir, palavras empregadas com a intenção de suavizar a comunicação de morte e uma que é mais um afrontamento.

Quadro 7 - Palavras de sentido conotativo

\begin{tabular}{|c|c|c|}
\hline \multirow[b]{2}{*}{ Países } & \multicolumn{2}{|c|}{ Modos de se comunicar a morte } \\
\hline & $\begin{array}{l}\text { Atitude diplomática } \\
\text { Eufemismo }\end{array}$ & $\begin{array}{l}\text { Atitude de enfrentamento } \\
\text { Disfemismo }\end{array}$ \\
\hline Brasil & $\begin{array}{l}\text { Descansar } \\
\text { Desencarnar } \\
\text { Falecer } \\
\text { Fenecer } \\
\text { Partir } \\
\text { Passar } \\
\text { Viajar }\end{array}$ & \\
\hline Canadá & $\begin{array}{l}\text { Descansar } \\
\text { Falecer } \\
\text { Partir } \\
\text { Passar } \\
\text { Viajar }\end{array}$ & Sucumbir \\
\hline Noruega & $\begin{array}{l}\text { Adormecer } \\
\text { Descansar } \\
\text { Dormir } \\
\text { Falecer } \\
\text { Partir } \\
\text { Viajar }\end{array}$ & \\
\hline
\end{tabular}

Das palavras que constituem eufemismo, a menos conotativa é falecer que, de tão convencional, já foi incorporada pelas pessoas como uma palavra denotativa nos três países. As outras, se ainda não estiverem consolidadas pelo uso ou pela prática na região em que são empregadas, dependem muito do contexto de situação para serem compreendidas. Caso não haja esse contexto aliado ao linguístico, pode até ocorrer certo constrangimento. Pelos dados, é possível afirmar que Brasil, Canadá e Noruega se aproximam, utilizando a palavra descansar em casos de morte por velhice, ou em que a pessoa estava lutando contra alguma doença grave ou com algum problema sério. No Canadá, encontramos também a palavra sucumbir que pode ser considerada um 
disfemismo com certo grau de opacidade. Usa-se essa palavra quanto a pessoa falece em consequência de câncer. No Brasil, se a pessoa é espírita, usa-se o verbo desencarnar. Assim, como bem observou Azeredo (Cf. 4.2.1.4-B), os desvios do eufemismo e do disfemismo "manifestam seu rendimento no desacordo da relação de verdade entre o que se diz literalmente e a realidade da qual se fala". Por isso, para que se entenda o sentido atribuído não só a determinadas expressões, mas também a certas palavras conotativas cujos significados sejam morrer, é de suma importância o conhecimento do referente. Ainda mais se os interactantes forem de regiões de convenções linguísticas distintas.

Quanto ao emprego do verbo morrer, objetivamente, ele é mais frequente em algumas regiões da Noruega, e em outras do Canadá, onde, às vezes, só é empregada quando já se esperava a morte. No Brasil, o termo denotativo é empregado, com mais frequência, nas situações de comunicação onde se emprega preferencialmente o registro mais próximo à norma padrão, como nos casos das notícias veiculadas na imprensa, em comunicados oficiais corporativos, por exemplo, ou, ainda, quando o falante não guarda qualquer tipo de sentimento afetivo positivo para com a pessoa falecida, e, por isso, permite-se fazer um comunicado do tipo diretivo. A seguir, um informante norueguês aponta nossa indiretividade e revela a própria diretividade:

\section{09 (NO), L. 98-103}

Vocês têm mania de dizer: "Ela dormiu.", "Foi levada.". Tem alguns que gostam de explicar para as crianças: "Agora, ela tá dormindo para sempre.", mas é meio comum explicar que ela morreu. Eu, para meus filhos, sem dúvida, disse: "Vovó morreu. E, agora, a gente não sabe onde ela foi.". (sic)

\subsubsection{Linguagem Não Verbal}

Retomando Tagnin (Cf. 2.2.1.2), "a convencionalidade abrange tudo o que é convencional", obedecendo a padrões sociais. É costume de brasileiros, canadenses e noruegueses expressarem seus cumprimentos também por meio de uma linguagem não verbal, quer entregando ou enviando um cartão, quer oferecendo flores. Esse procedimento é uma prática comum no Canadá e na Noruega, onde as pessoas do convívio social do ente querido ou de sua família 
enviam cartões e flores para a família enlutada, cumprindo regras de boa educação e de boa conduta. Também como regra, na Noruega, a família, depois da celebração da vida do falecido, envia um cartão de agradecimento, retribuindo a gentileza recebida. No Brasil, tal protocolo pode acontecer, mas não se caracteriza como uma convenção. Quanto às flores, elas não aparecem na pesquisa, sendo enviadas para a casa da família enlutada.

Quando não se sabe o que dizer, na hora dos cumprimentos, as pessoas podem se expressar com gestos formais, como aperto de mãos; ou afetivos, como abraços e beijos. Confirmando a teoria de Lewis de que somos bem extrovertidos e táteis (Cf. 2.1.3.2.1), o brasileiro se manifesta muito através do contato físico, do abraço forte, demorado, e de beijos. Quanto ao canadense e ao norueguês, em funerais, pelas variações observadas, aparentemente eles vão, de certa forma, de encontro à ideia de Lewis (Cf. 2.1.3.2.2 e 2.1.3.2.3) no que se refere à categoria espaço pessoal, pois, dependendo da relação entre os interactantes, há os que fazem uso do aperto de mãos e do abraço. Seja como for, a pesquisa corrobora Tagnin, porque revela hábitos comportamentais de cada um desses países comprovando suas convenções sociais nos contextos de situação e cultura. Isso se verifica nas palavras dos informantes abaixo.

\section{21 (BR), L. 74-77}

O abraçar é o mais comum no momento do cumprimento. Mesmo as pessoas que não têm hábito de abraçar. Quando você aperta a mão, guarda uma distância, fica um vazio que é, em geral, preenchido pelas palavras. Quando você não sabe muito o que vai dizer, corre logo pra abraçar, porque aquilo ali já cala no abraço. (sic)

\section{05 (CA), L. 50-52}

A gente aqui não se abraça como a gente no Brasil, mas, no funeral, se a pessoa é da família, você vai abraçar. A pessoa que conhece do escritório, talvez, você só vai apertar a mão dele. Depende do relaxionamento. (sic)

I 18 (BR), L. 67 [Falando sobre a celebração da vida, logo após o funeral na Noruega.]

É emocionante, sabe? As pessoas mais próximas recebem abraços, você abraça também. (sic) 


\section{06 (NO), L. 61-64}

Só cumprimentam com aperto de mão. Abraços só se for alguém muito, muito próximo, não é comum. O momento de abraços entre os familiares só em casa, em público, não. Dizem minhas condolências, meus profundos sentimentos. (sic)

Outra forma de linguagem não verbal citada pelos informantes é a expressão fisionômica. Pela face e/ou pelo olhar, por uma lágrima que cai, por um sorriso, a pessoa pode comunicar sentimentos de carinho, tristeza, solidariedade, qualquer que seja a cultura que represente. Em funerais, no Brasil, em geral, manifesta-se a perda do ente querido pelas lágrimas, mas também pelo olhar tristonho, pelo semblante; no Canadá e na Noruega, isso é muito relativo. Há os que não derramam uma lágrima; mas há aqueles que choram; uns mais, outros menos, como pode ser observado, a seguir, nos fragmentos de relatos extraídos das entrevistas.

\section{12 (BR), L. 44-45}

Às vezes, a gente vê lágrimas, mas não é aquele pranto desesperado que a gente vê no Brasil. (sic) [CA]

\section{05 (CA), L. 49-50}

Durante o funeral, o canadense chora. É tranquilo chorar, ninguém vai te reclamar pra chorar, especialmente a família. (sic)

\section{18 (BR), L. 67-72}

Apesar deles [noruegueses] não serem nada calorosos, nesse momento, eles são. Na missa, eles choram muito, talvez mais do que aí. Não só na missa, mas em todas as outras celebrações como aniversário. Nisso, eles são muito emotivos. Todo aniversário que eu fui teve choro quando uma pessoa começa a falar. Às vezes, alegre, outras triste, emocionante. É choro direto. É só alguém começar a falar. (sic)

O brasileiro é francamente emotivo e chora nos funerais; esse comportamento faz parte de nossa cultura. Nessa situação - e em outras também -, chorar em público não nos causa nenhum constrangimento. Contudo, cabe esclarecer que não somos escandalosos e desequilibrados como costumam nos caracterizar. Aqui, as pessoas se emocionam muito, mas são controladas. Existem casos isolados de pessoas que se permitem dar vazão exacerbada à emoção, mas 
isso pode estar ligado à educação formal do indivíduo, à sua condição social. A intensidade da reação depende do contexto do funeral: quem morreu, a causa da morte, se foi numa circunstância muito inesperada, como a morte violenta de um filho, por exemplo. Do mesmo modo, em qualquer cultura, desequilibrar-se emocionalmente por uma morte abrupta é muito natural. É certo que pessoas de cultura ativo-linear são muito mais contidas do que nós, brasileiros. A informante a seguir corrobora este ponto de vista.

\section{21 (BR), L. 65-70}

As pessoas choram. Algumas choram mais do que outras. Há pessoas que são mais emotivas e tal, mas, de um modo geral, ninguém dá espetáculo. Choram porque é natural que chore mesmo, é de se esperar. O que não é natural, mas que, às vezes, acontece, é a pessoa não derramar uma lágrima, a pessoa ficar ali impassível, que a gente fica até preocupada com a pessoa que não está vivendo o seu luto. Mas o comportamento, eu acho que varia mesmo em função da classe social. ( $\mathrm{sic}$ )

Todos esses dados confirmam também Hall (Cf. 2.1.2), que argumenta que linguagens não verbais incluem expressão facial, movimento e proximidade, entre outros comportamentos que dizem muito e variam não somente entre países, mas também regionalmente.

Como exposto até aqui, os dados mostram que o uso das expressões convencionais denotativa e conotativa, assim como a maneira de se vestir e a rigidez no controle das lágrimas em um funeral revelam valores de uma sociedade. Verificamos que o brasileiro, povo de cultura multiativa, emprega mais as expressões conotativas, na intenção de não ferir a face do outro, querendo expressar-se da forma mais carinhosa possível. Demonstra emoções e retribui o carinho das pessoas presentes. No Brasil de hoje, é muito raro divulgar a morte pelo jornal. Acompanhando as tendências no mundo todo, usam-se mais telefone, folhetos da igreja, e-mail, e cada vez mais, as mídias sociais, como o Facebook, Instagran e o WhatsApp, conforme se comprova na Figura 4: 


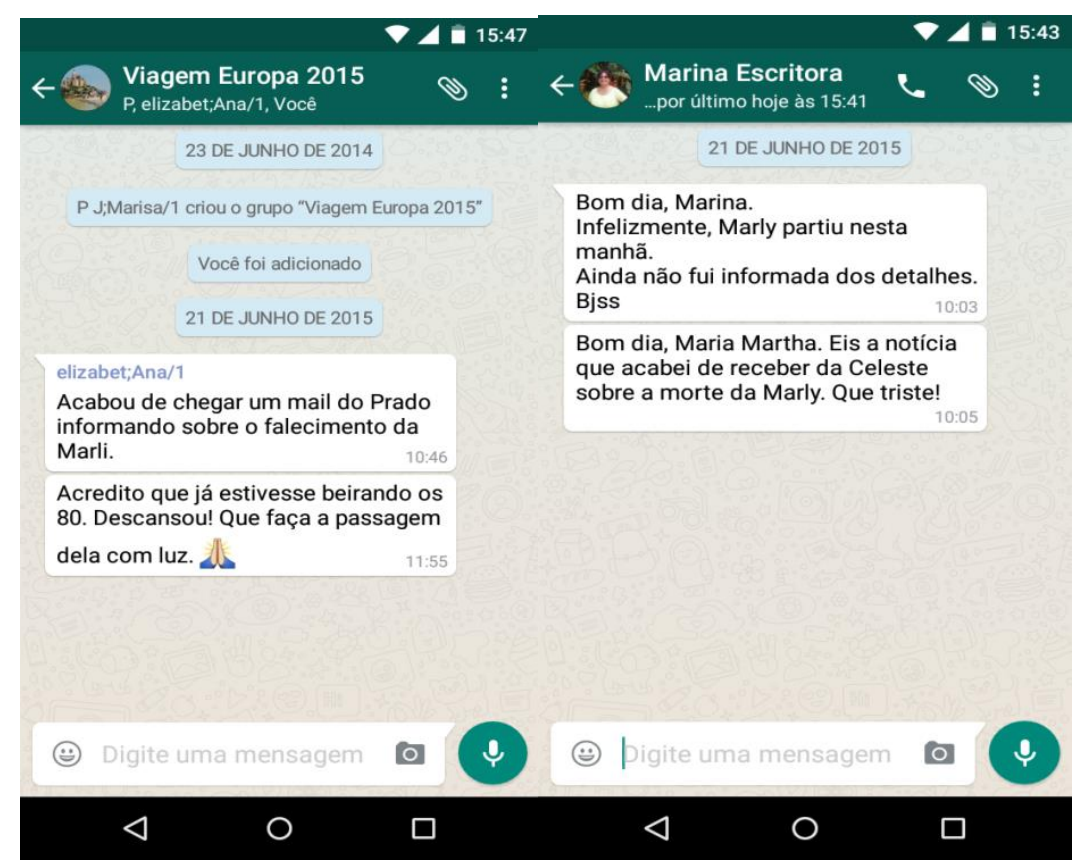

Figura 4 - Imagem WhatsApp (Arquivo pessoal da pesquisadora, 2015.)

Na Noruega, sempre que morre um nativo, coloca-se anúncio nos jornais e nos folhetos da igreja: faz parte da cultura do país. Além dessa divulgação, parentes e amigos que moram distante podem ser comunicados por e-mail, telefone, Facebook e WhatsApp.

Dessa forma, observando-se a linguagem humana, verbal e não verbal, como veículo de expressão de valores culturais e hábitos comportamentais, e de exteriorização de sentimentos pessoais, pode-se compreender um pouco a cultura do outro, ter consciência da própria e consequentemente se adquirir a competência intercultural primordial nas interações face a face.

\subsection{Outros Achados Linguísticos}

Como já anunciado na Introdução deste trabalho, a Análise se assentou nas teorias que dizem respeito às convencionalidades e às linguagens verbais e não verbais representativas das diferentes culturas aqui abordadas, mas também ela nos revelou um corpus rico de impressões dos informantes acerca do interculturalismo decorrente dos contatos pessoais, as quais não podem passar despercebidas e igualmente merecem destaque.

Assim, passamos a apresentar um panorama da interpretação dos dados a partir da compilação das repostas dos informantes às 15 questões da segunda 
etapa das Entrevistas (Cf. Quadros 8, 9, 10, 11 e 12). Com isso, temos o objetivo de facilitar, para os leitores, o manuseio e a visualização de um vasto material, reduzindo em muito o volume de leitura. Os informantes responderam a todas as perguntas, mas, algumas vezes, talvez por certa dificuldade de entendimento da língua, ou em razão de menor facilidade de expressão, uns se expressaram de forma equivocada, ou não se ativeram a responder apenas ao que era perguntado, afastando-se do ponto central da questão e, por isso, não tendo seu relato computado no quadro-resumo, ou tendo-o registrado apenas parcialmente. Foram também suprimidas as ideias repetidas por mais de um informante, prevalecendo o fragmento de texto que apresentou melhor redação. $\mathrm{O}$ número de entrevistados que preencheu cada item está contabilizado entre parênteses, sendo que, no Quadro 12, as opções foram preenchidas com (x), por se tratar de apenas uma informante.

Desse modo, estes quadros, contendo apenas respostas pertinentes ao cerne das questões, além de propiciarem o sumo do corpus, vão subsidiar a Análise, à medida que dados brasileiros, canadenses e noruegueses se aproximem, ou se afastem de forma significativa, para procedermos à sua interpretação. Quando os dados apontarem traços pertinentes aos três países, esses serão comentados após o último quadro. Note-se que as informações coletadas não apontaram relevância em relação à faixa etária e ao gênero conforme se supunha, inicialmente, na etapa de elaboração do formulário de entrevista e do questionário aplicado aos informantes.

A seguir estão compiladas, no Quadro 8, as respostas coletadas do grupo composto por canadenses que vivem ou viveram no Brasil.

Quadro 8 - Compilação das respostas do Questionário da segunda etapa da coleta de dados canadenses

\begin{tabular}{|l|l|}
\hline Nacionalidade: Canadense & $\begin{array}{l}\text { Identificação dos Informantes: } \\
\mathbf{0 1 , 0 2 , 0 3 , 0 4 , 0 5}\end{array}$ \\
\hline 1 - Em termos de linguagem, em seu país, para comunicar um falecimento: \\
( 5 ) usam-se expressões com a preocupação de abrandamento. Ex.: Ir pra um lugar \\
melhor, Ir pro outro lado, Falecer, Pass away, Ir embora. \\
( 5 ) fala-se diretamente a palavra MORTE ou derivativos. Ex. Quando já se sabia
\end{tabular}


que a pessoa ia morrer.

( 3 ) dependendo do defunto, usam-se expressões grosseiras ou ofensivas. Ex.: Para pessoa pública que não se admirava (político, ator, cantor): Chutar o balde

( 3) dependendo do falante, podem aparecer expressões pouco sociáveis (gírias, termos inadequados à situação). Ex.: game over, Chutar o balde, Comprar a fazenda.

( 2 ) existem expressões específicas para referência ao tipo de morte, isto é, se a morte foi por velhice, por acidente, por câncer. Ex.: Por câncer: sucumbir; por acidente e outras doenças graves: acontecer algo fatal.

\section{2 - Logo após a morte, os familiares mais próximos:}

( 4 ) fazem gestos carinhosos como acariciar ou beijar o rosto do defunto.

( 5 ) são chamados a velar o corpo em separado, antes dos ritos funerais públicos.

I. $02 \rightarrow$ Se a morte for por acidente ou por causa incerta, a família não tem acesso ao corpo. Ele vai direto para a autópsia.

I. $04 \rightarrow$ Minha tia arrumou minha mãe bonitinha, do jeito que ela gostava de ser vista. (sic)

\section{3 - Na seção Obituário do jornal, por ocasião dos óbitos:}

( 5 ) é comum fazerem comunicações públicas.

( 4 ) há casos em que fazem restrições às celebrações, como não levar flores.

( 2 ) há outras restrições.

( 4 ) há casos em que sugerem doações para determinada instituição.

( 4 ) há casos em que comunicam que não haverá celebrações.

( 3 ) há outros meios e/ou casos.

I. $01 \rightarrow 1$ - É comum pedir para não levar flores, mas enviar uma contribuição para ajudar determinada instituição. (sic)

$\rightarrow 2$ - Uma amiga que morreu de câncer não queria que outras pessoas soubessem de sua morte. Não houve anúncio no jornal. (sic)

I. $02 \rightarrow 1$ - Não é comum, mas pode acontecer de a pessoa ser convidada para a igreja, mas não para o cemitério nem para a cerimônia festiva. (sic)

I. $04 \rightarrow 1$ - A geração atual não usa muito esse tipo de divulgação. Parece que não lê mais jornal. As pessoas acima de 40 anos sim. (sic)

Obs.: Além do jornal impresso, usam jornal online, jornal das igrejas. Para 


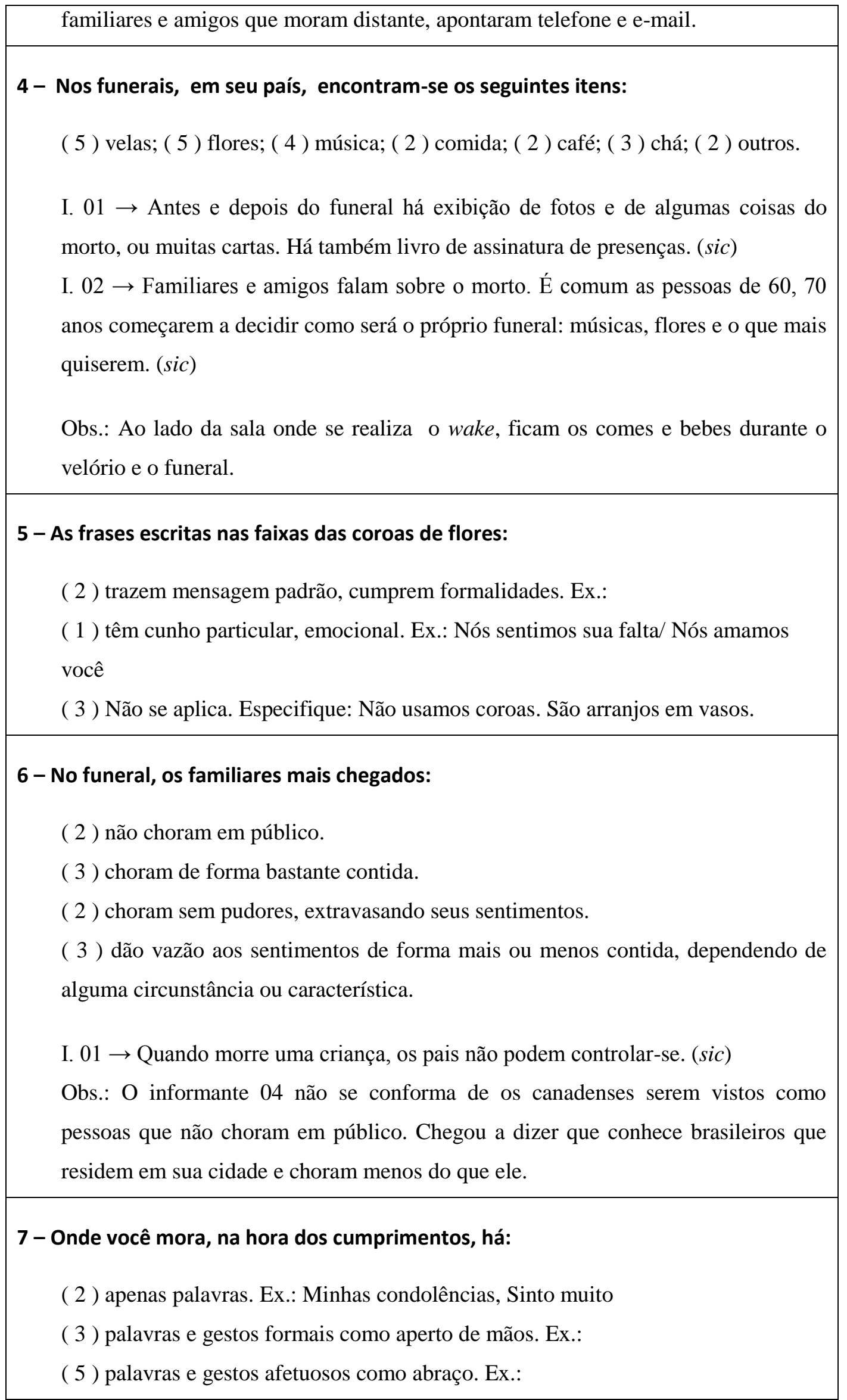


( - ) apenas abraço.

( - ) outros.

I. $01 \rightarrow$ Depende da relação. Para a família de colegas de trabalho, usa-se aperto de mãos. Se a família e o morto forem conhecidos, pode-se usar o abraço, mas depende do conforto da pessoa com contatos físicos. (sic)

I. $04 \rightarrow$ Dependendo do grau de proximidade entre as pessoas, pode haver abraço forte. (sic)

Obs.: Nesse momento, independente do contato físico, a expressão mais usada é Sinto muito por sua perda. Usam-se também palavras de simpatia sobre o morto e de encorajamento à família.

8 - Quando há a celebração da vida do ente querido, com comes e bebes, após o funeral ou o enterro, os lugares possíveis para esse evento são:

( 5 ) a casa dos familiares ou de amigos;

( 4 ) um espaço na casa funerária;

( 4 ) um salão na igreja;

( 2 ) um restaurante;

( 2 ) uma casa de festas;

( - ) um hotel de luxo; outros.

Obs.: Embora a casa da família enlutada seja sempre uma opção, comemoram mais esse evento na igreja ou na casa funerária. (sic)

9 - São convidados a participar dessa cerimônia.

( 2 ) apenas os familiares;

( 4 ) familiares e amigos somente;

( 2 ) familiares, amigos e demais convíveres sociais (vizinhos, colegas de trabalho);

( 2 ) um religioso da religião do morto;

( 1 ) todas as pessoas conhecidas do morto, independente do grau de intimidade.

I. $04 \rightarrow$ A celebração da vida de minha mãe foi num teatro, e foi anunciado que todos eram bem-vindos. (sic)

Obs.: Depende da família, do tipo de morte, da hora e do local do evento. Em geral, especificam-se quais são os convidados na divulgação da morte no 


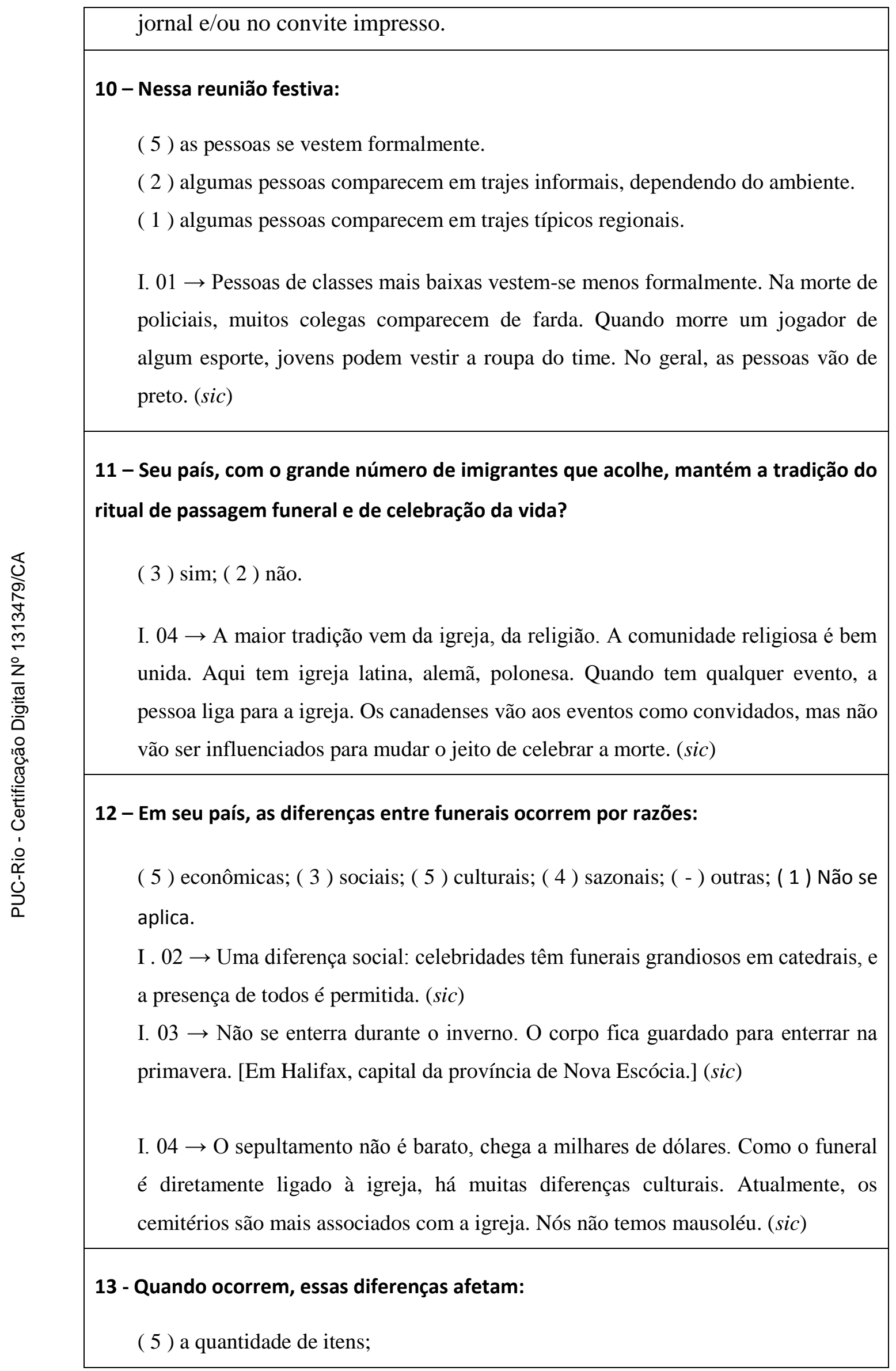




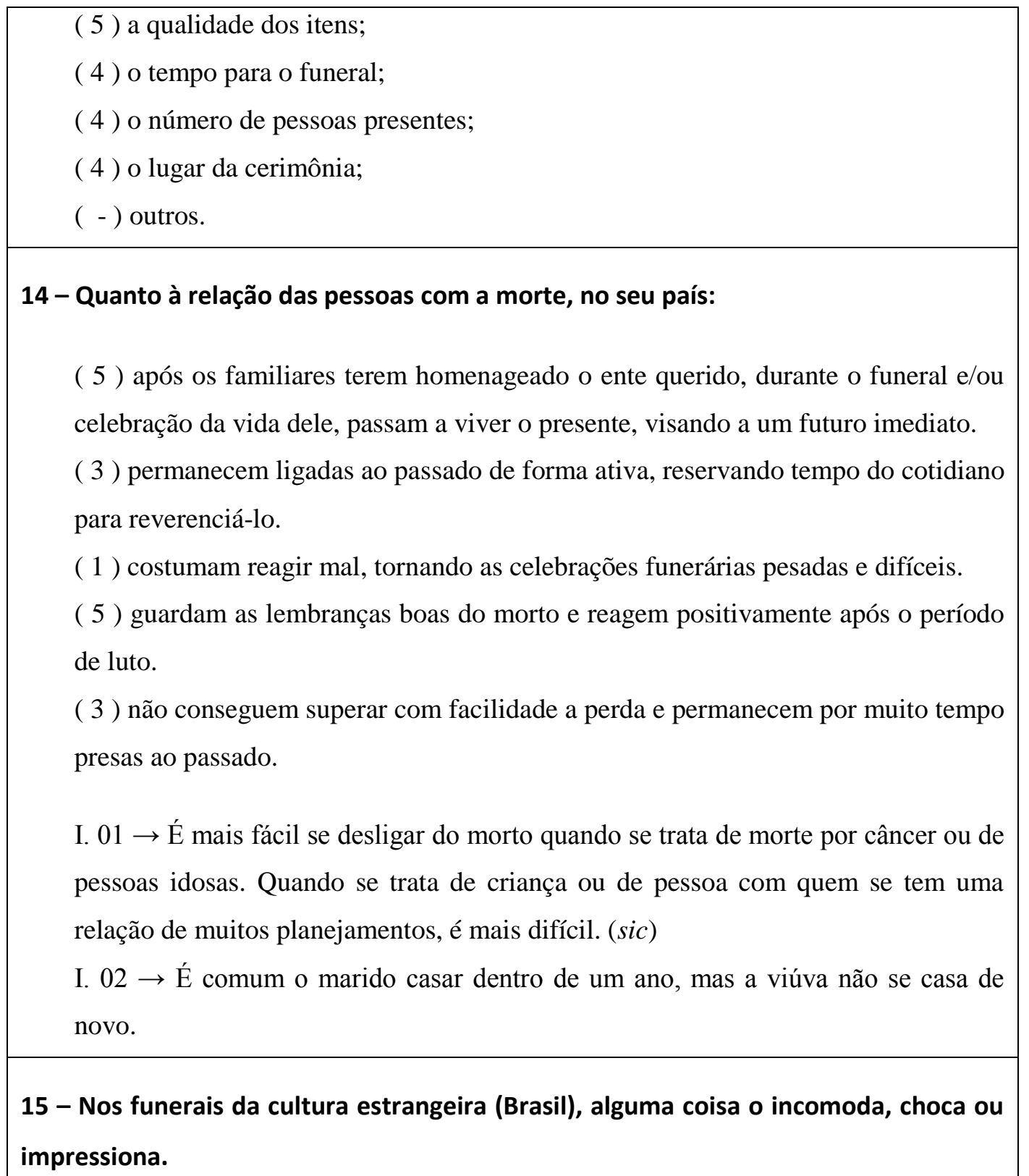

( 4 ) sim; ( - ) não; ( 1 ) Não se aplica.

I. $01 \rightarrow$ Não choca para mim, não incomoda, mas impressiona. Impressiona como não saber, exatamente, o que eu deveria fazer, quando e onde. Algumas horas de incerteza, então, pouca incerteza é normal, mas muito não é. Porque eu vivia com a família hospedeira e, então, eu não sabia o que eu deveria fazer amanhã, nada. $\mathrm{O}$ corpo todo coberto de flores me incomodou, porque para Canadá são possibilidades: primeiro, não podemos ver o corpo; segundo, vimos uma parte do corpo, não somente o rosto. Podemos ver do peito pra cima. O tempo de um dia para outro foi muito rápido e a incerteza de tantas horas. (sic) 


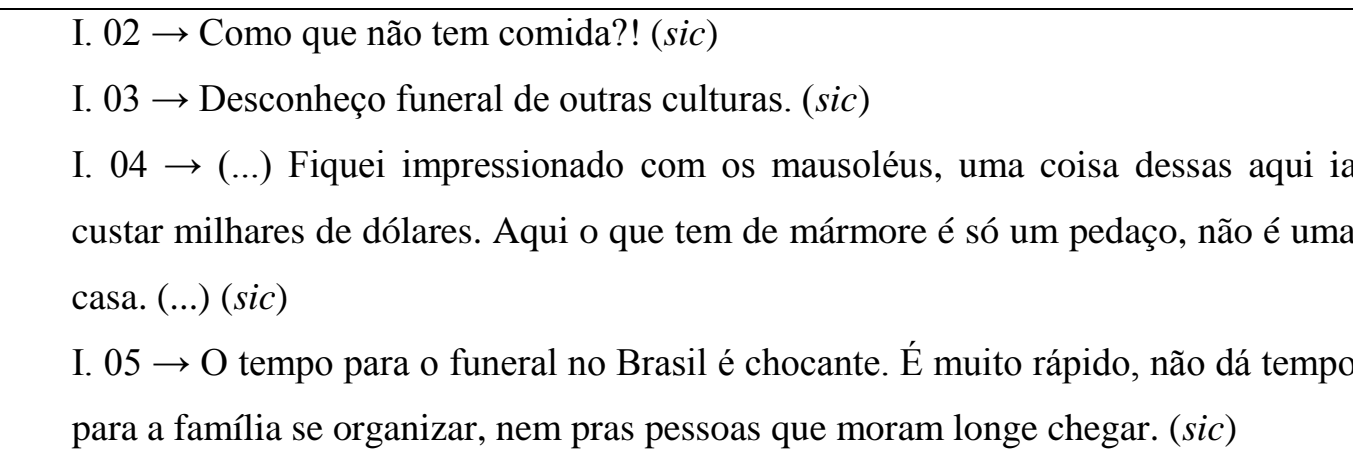

Nesse quadro, o informante 04 nos chama atenção por alguns comportamentos, aparecendo como uma grande variante em seu grupo. Em seu país, quando uma pessoa morre, a família apenas liga para a casa funerária, escolhe os itens do pacote e não toca mais no corpo. A agência funerária cuida de tudo, e a família paga a conta. Em seu relato na questão 2, identificamos o único espaço ambíguo que podemos chamar de arrumação do corpo, pois a tia cuidou do corpo da mãe. Além da atitude dela, o uso do diminutivo bonitinha reforça que a casa engloba a rua (Cf. 2.14.1.2). Na questão 10, ele afirmou que, no enterro da mãe, a maioria das pessoas vestiu-se informalmente, rompendo mais uma vez com tradições canadenses.

Em termos de linguagem verbal, cabe destacar $o$ fato de que unanimemente os informantes relatam a coexistência das situações de diretividade e indiretividade, quando assinalam que as notícias de morte podem ser dadas das duas formas, dependendo da situação.

Isso, de certo modo, não sustenta a percepção de Lewis (Cf. 2.1.2) de que os canadenses, em sua cultura de baixo contexto, são conhecidos por se expressarem de modo aparentemente mais frio, em comparação com os brasileiros. Note-se ainda a respeito desse dado que, na questão 6, um dos informantes manifesta sua inconformação com o fato de se dizer que canadenses não choram em público. Para ratificar a análise inferida desses dados, podemos buscar, na questão 7, o dado levantado de que uns canadenses entrevistados ficaram divididos entre a primeira e a segunda opção, mas todos assinalaram preferencialmente a terceira quanto à linguagem não verbal adotada nesse tipo de situação : palavras e gestos afetuosos como o abraço. 
O mesmo se pode observar, com relação aos noruegues, pois uns ficaram divididos entre a primeira e quarta opção, porém todos assinalaram a segunda e terceira, conforme descrito no Quadro 9, adiante.

Cabe destacar que, na questão 10 do Quadro 8, as respostas mais uma vez são unânimes para o modo como as pessoas se vestem no Canadá para os funerais: formalmente. Note-se que ao mesmo tempo que a informante 01 salienta o fato de que as pessoas com menor poder aquisitivo se vestem com menos informalidade, ela própria relata o uso de uniformes no caso de falecimento de militares e esportistas. Ora, o conceito de formalidade fica questionado nesse discurso, parecendo que a questão passa pelo entendimento de que o formal está mais ligado à qualidade da roupa do que propriamente à convencionalidade apontada por Tagnin (Cf. 2.2.1.2). Os dados coletados na questão 12 corroboram essa interpretação, quando todos os entrevistados assinalaram que o poder econômico determina a quantidade e a qualidade dos itens usualmente encontrados nos ritos de passagem pós-morte canadenses.

O Quadro 9 apresenta as respostas coletadas do grupo composto por noruegueses que vivem ou viveram no Brasil.

Quadro 9 - Compilação das respostas do Questionário da segunda etapa da coleta de dados noruegueses

\begin{tabular}{|l|l}
\hline Nacionalidade: Norueguesa & Identificação dos Informantes: \\
& $\mathbf{0 6 , 0 7 , 0 8 , 0 9 , 1 0}$ \\
\hline
\end{tabular}

1 - Em termos de linguagem, em seu país, para comunicar um falecimento:

( 5) usam-se expressões com a preocupação de abrandamento. Ex.: Partir, Não estar mais entre nós, Passar pela última viagem, Ir embora, Passar, Viajar, Não estar mais aqui, Dormir, Adormecer

( 5) fala-se diretamente a palavra MORTE ou derivativos. Ex. Acontece mais quando anuncia morte de quem não era próximo. Uma coisa que você ficou sabendo, por exemplo. (...) (sic)

(3) dependendo do defunto, usam-se expressões grosseiras ou ofensivas. Ex.: Ir pro descampado; Usam morrer, mas com uma entonação grosseira.

(3) dependendo do falante, podem aparecer expressões pouco sociáveis (gírias, termos inadequados à situação). Ex.: Muito raramente, um jovem pode dizer 


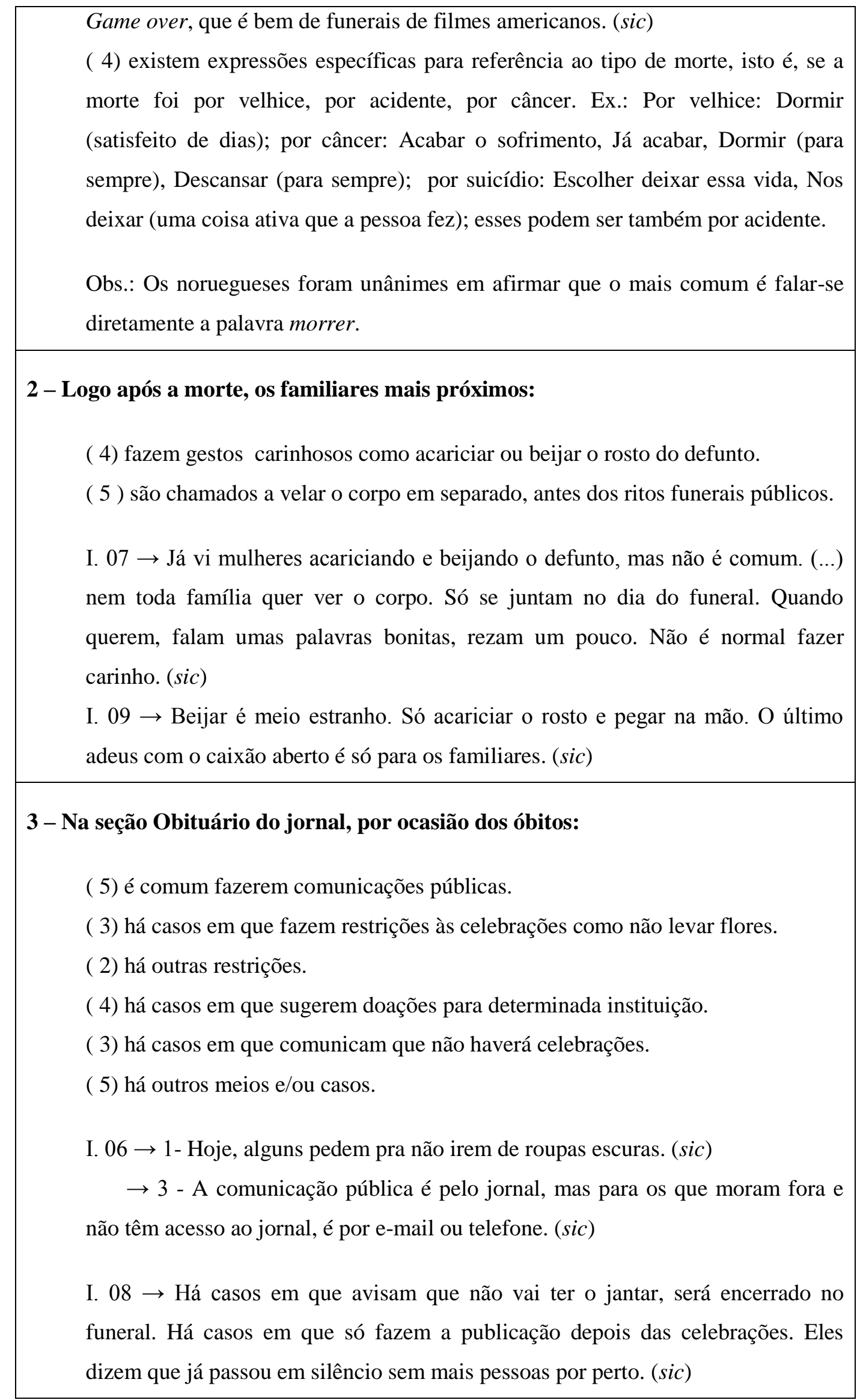




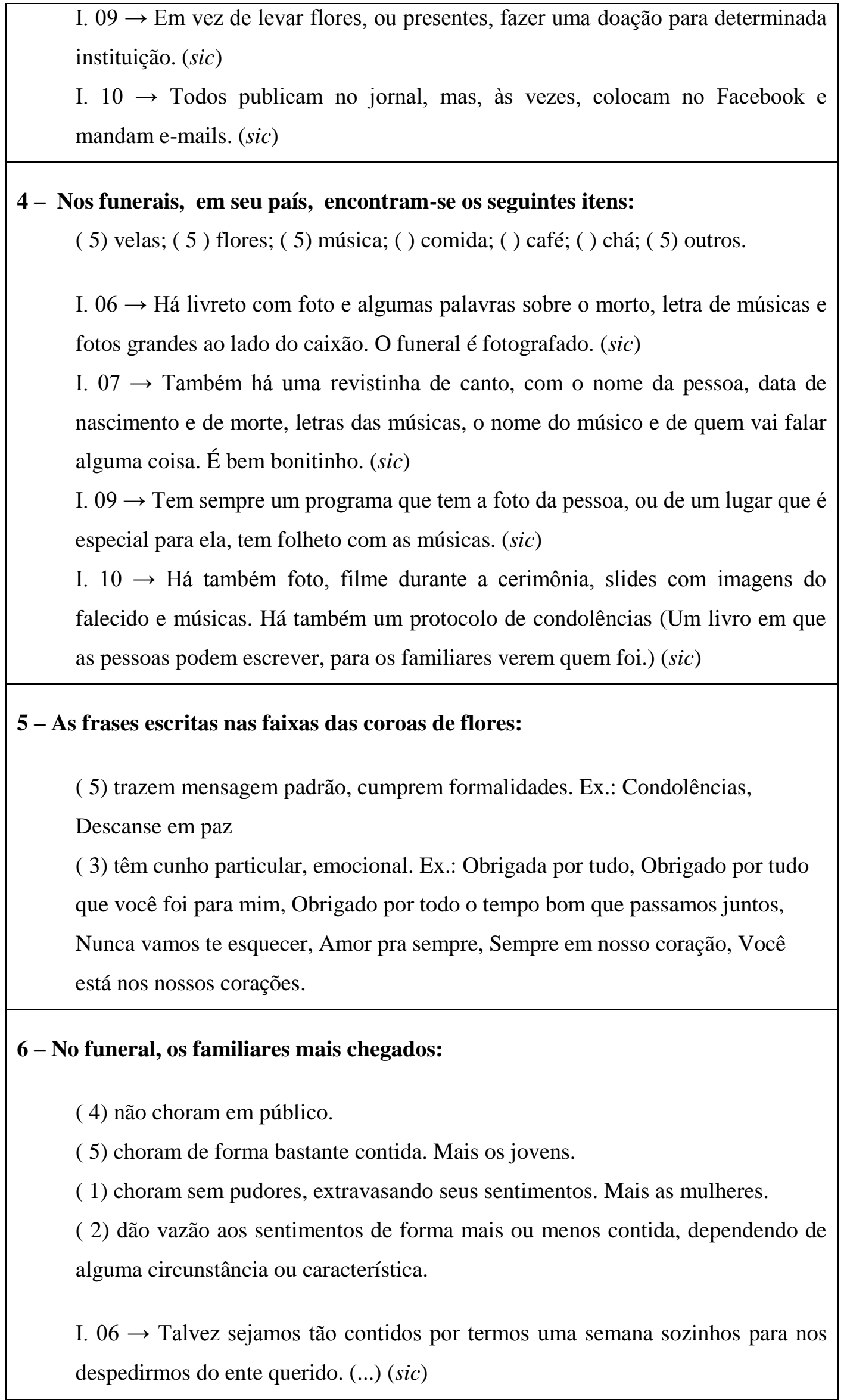




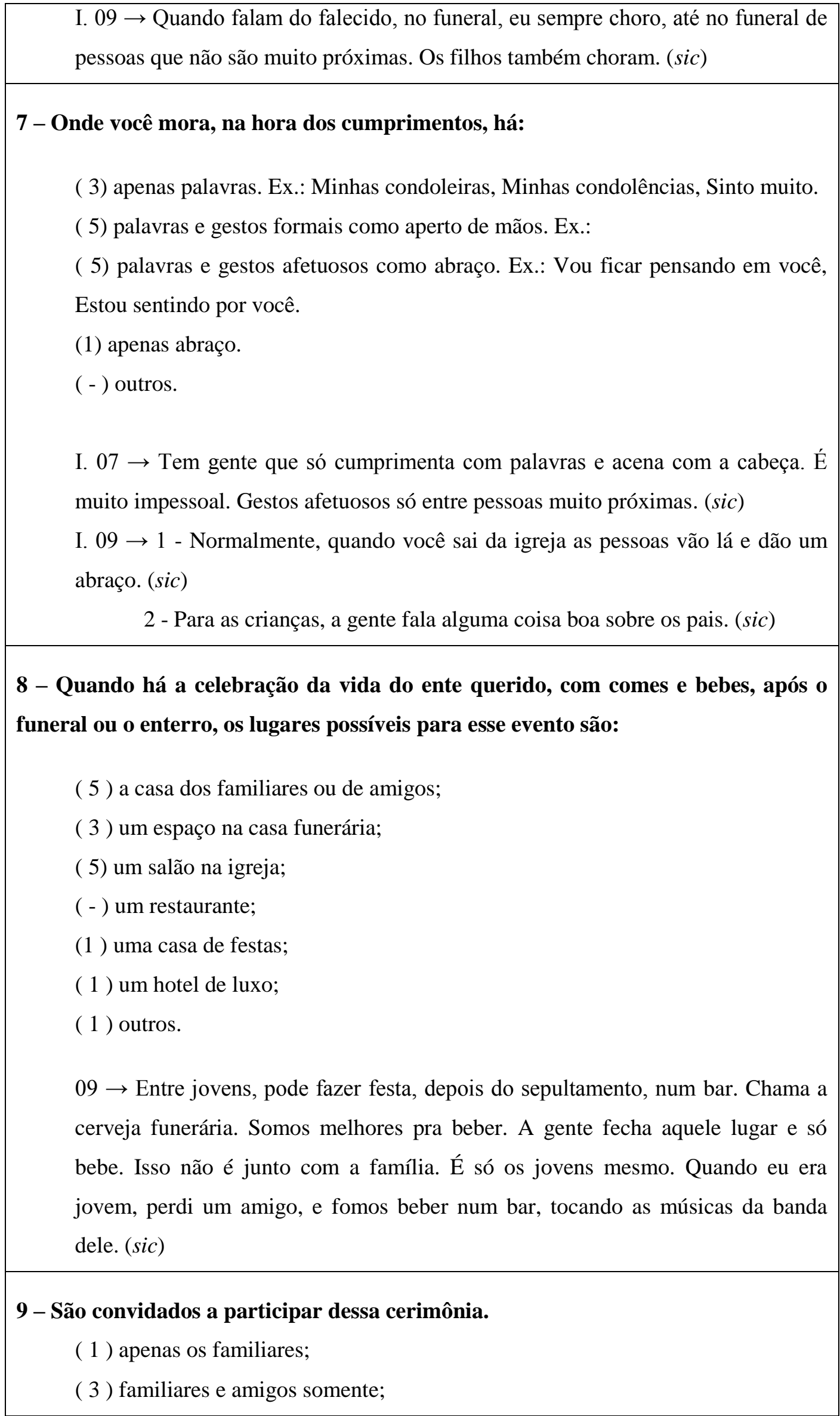




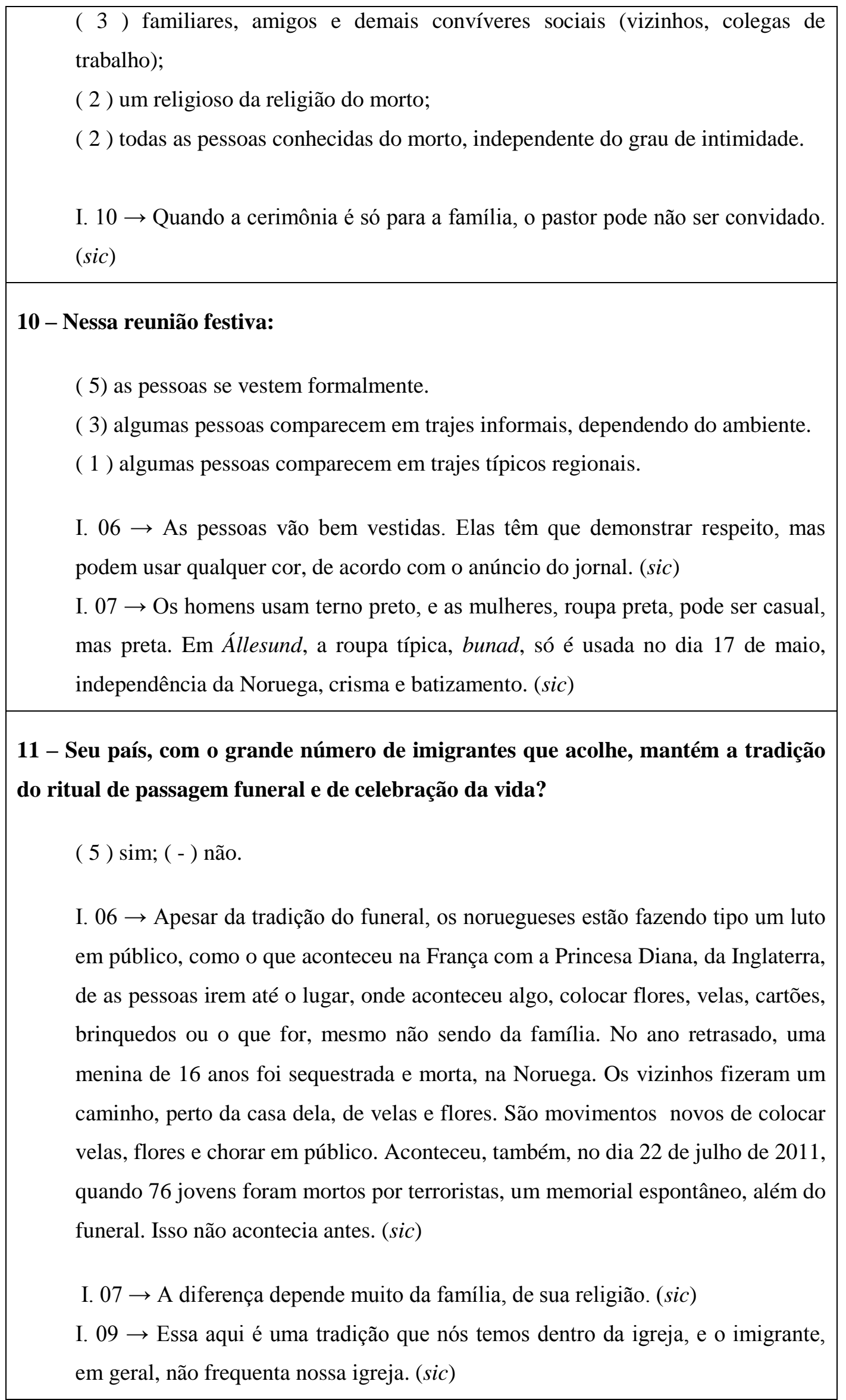




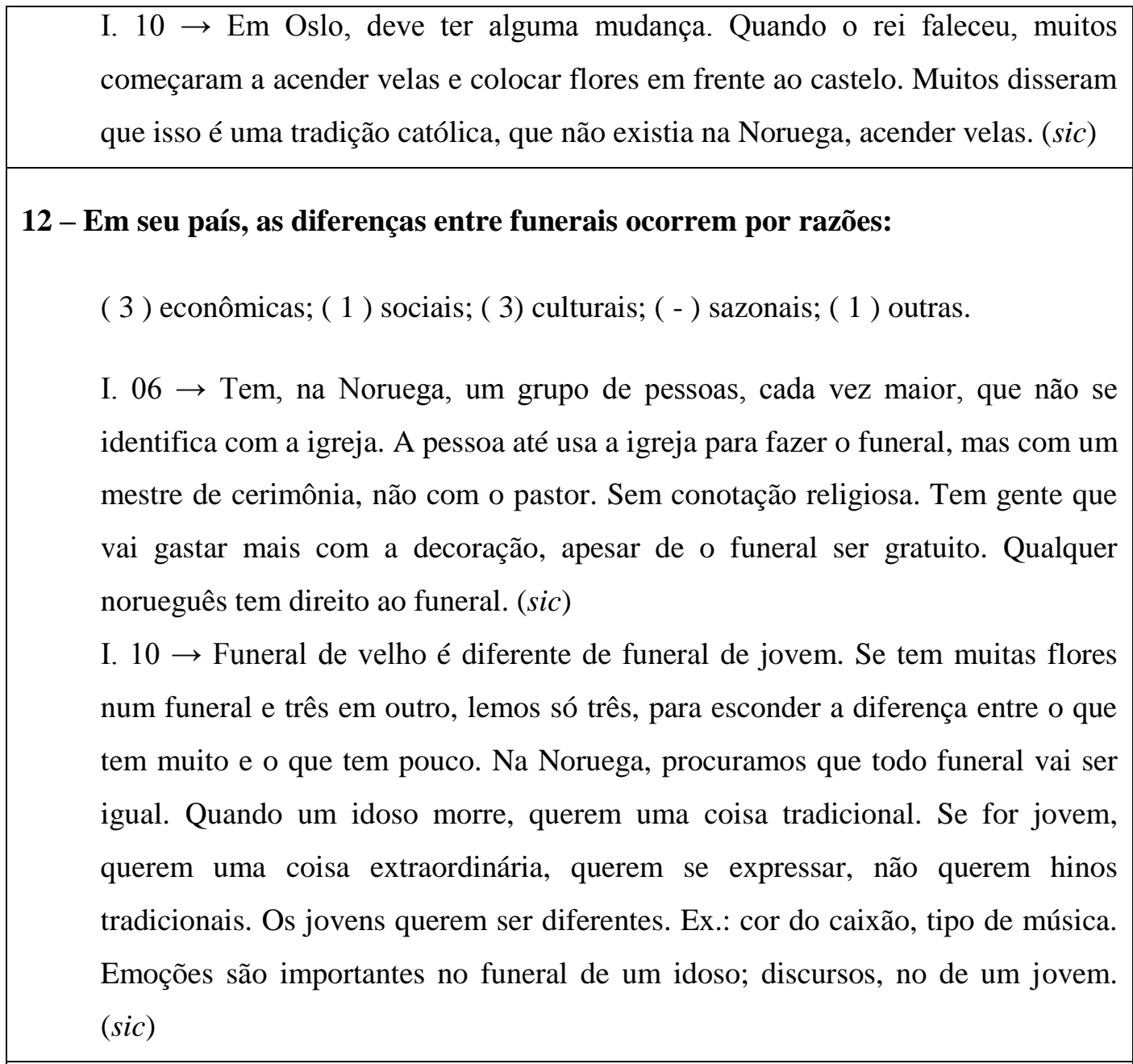

13 - Quando ocorrem, essas diferenças afetam:

( 3) a quantidade de itens;

( 2 ) a qualidade dos itens;

( 1 ) o tempo para o funeral;

( 3 ) o número de pessoas presentes;

( 3 ) o lugar da cerimônia;

( - ) outros.

I. $09 \rightarrow$ Você não paga nada para fazer o funeral na igreja. Você já paga os impostos. O que pode mudar é a qualidade das flores, o músico e a recepção.

Você pode ter uma coisa simples e bonita, com flores da natureza. (sic)

I. $10 \rightarrow$ Quase sempre, é na igreja. O de um jovem tem mais pessoas. (sic)

14 - Quanto à relação das pessoas com a morte, no seu país: 


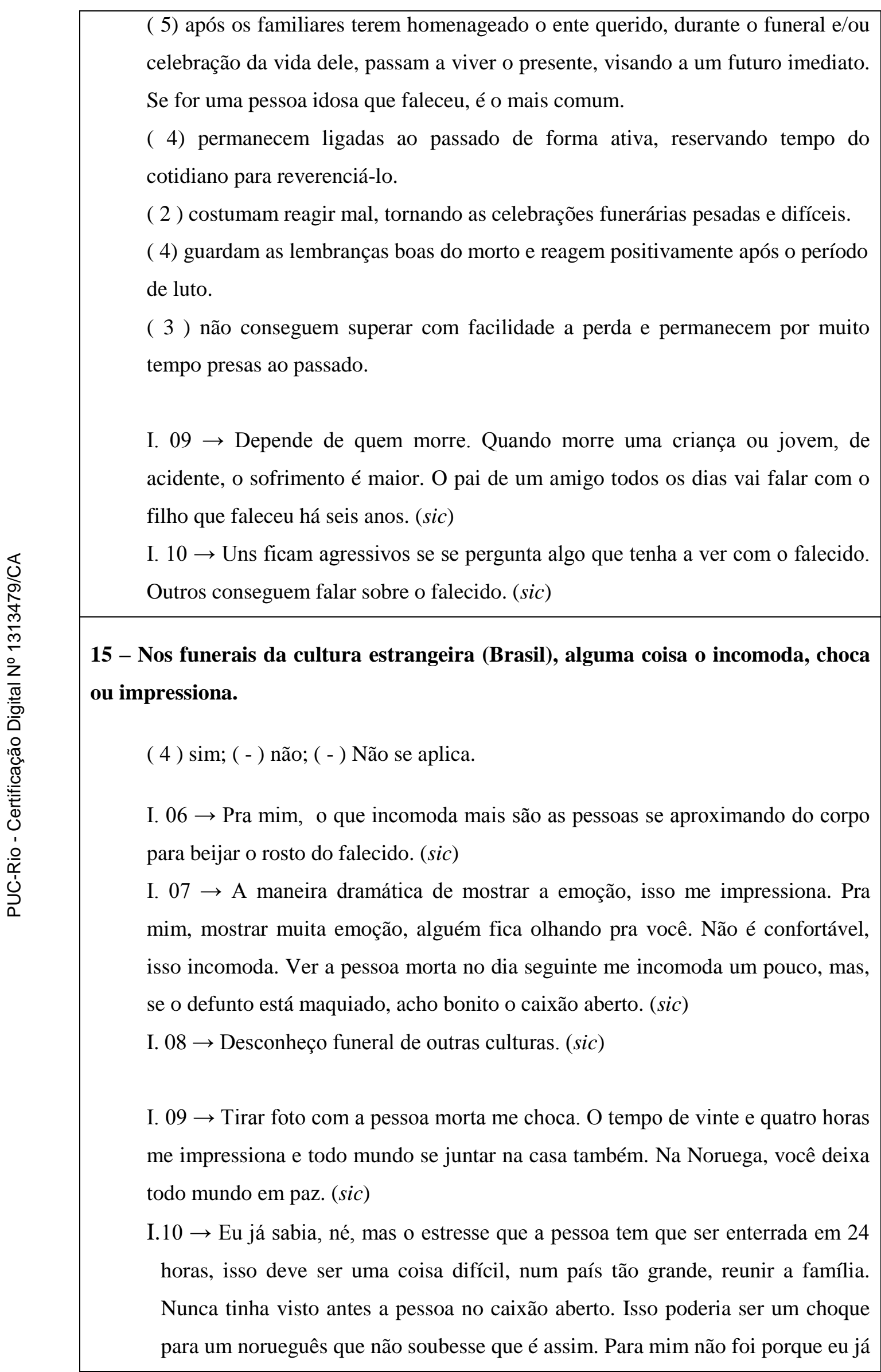


sabia. Mas achei estranho. (sic)

A análise específica dos dados fornecidos pelos noruegueses traz em destaque, em relação aos demais, a intensidade do estranhamento diante das cenas vividas no Brasil. O assunto está mais evidente na questão 15, mas também surge nos comentários feitos pelos informantes na questão 2 .

No que se refere aos fatos de o funeral, no Brasil, realizar-se em 24 horas e de o caixão permanecer aberto até o momento do sepultamento ou da cremação, as culturas monocrônicas canadense e norueguesa convergiram, afastando-se da cultura brasileira. Às pessoas das duas primeiras culturas, a nossa causa um incômodo significativo. Além de precisarem de, pelo menos, uma semana para se planejarem, no país nórdico a exposição do corpo é apenas para os familiares, e nos dois países o funeral transcorre com o caixão lacrado.

Na questão 2 do Quadro 9, noruegueses disseram que a ideia de beijar o falecido é inadmissível. Isso se refletiu no discurso da informante 06, uma norueguesa que mora há mais de 20 anos no Brasil, ao responder o que mais a incomoda em funerais em nosso país.

Além desse incômodo, um dos informantes noruegueses revela um estranhamento em funerais no Brasil que não se repete em todas as regiões do país, mas que é uma prática registrada em cidades do interior de Minas Gerais, Goiás e Tocantins: fotografar o corpo dentro do caixão.

Se atentarmos para a escolha lexical do relato do informante 9, em seu comentário para a questão 15: “ (...) você deixa todo mundo em paz.”, identificaremos o pensamento de Lewis, na comprovação da autossuficiência do norueguês e do espaço pessoal de que ele precisa para se sentir confortável (Cf. 2.1.3.2.3), em contraposição à hospitalidade do brasileiro e ao fato de não sentirmos incômodo em nos aproximarmos uns dos outros. Interagimos também por meio de tapinhas, abraços e beijos (Cf. 2.1.3.2.1). O que nós consideramos demonstração de apreço e solidariedade é claramente interpretado nos países de cultura ativo-linear como gesto inconveniente e até incômodo. Essa divergência entre as duas nacionalidades corrobora a ideia de Hall de que cada pessoa tem, em torno de si, uma bolha cujo tamanho varia de cultura para cultura e de acordo com a situação em que o interactante se encontra e com quem ele está interagindo (Cf. 
2.1.2). O discurso desse informante vai ainda de encontro ao conceito de espaço ambíguo (Cf. 2.1.4.1.2). Nós, brasileiros, em contextos de situação pós-morte, compartilhamos a ideia de que podemos sobrepor o espaço das relações de afetividade ao espaço onde impera o individualismo.

Mais uma particularidade em relação aos noruegueses que se infere dos dados compilados no Quadro 9 diz respeito à questão 11. Ali os informantes foram unânimes em sua avaliação de que a Noruega mantém suas tradições em relação aos ritos de passagem funeral, apesar da presença de tantos imigrantes. Contudo, a leitura dos comentários apensados à questão revela que já há, sim, certa contaminação dos costumes, muito provavelmente como efeito da globalização, além da inserção de elementos das culturas estrangeiras circulantes no país. Quando os informantes 06 e 10 se lembram de cenas atuais que lhes chamaram atenção, deixam claro que alguns comportamentos e elementos incomuns à tradição norueguesa, mas bastante adotados em outras culturas, hoje, fazem parte das manifestações do país nas ocasiões de eventos pós-morte, como um memorial espontâneo, que consiste em as pessoas irem até o lugar do acidente colocar flores, velas e cartões, mesmo não sendo da família. Note-se, pelas respostas diversas que deram ao mesmo item da pesquisa, que os canadenses entrevistados não têm mais essa impressão conservadora de si mesmos.

Na sequência, estão compiladas, no Quadro 10, as respostas coletadas do grupo composto por brasileiros que vivem ou viveram no Canadá.

Quadro 10 - Compilação das respostas do Questionário da segunda etapa da coleta de dados brasileiros no Canadá

Nacionalidade: Brasileira

Identificação dos Informantes: $11,12,13,14,15$

Obs.: Os informantes 11, 12,13 e 15 responderam tudo tendo como referente o Canadá; a informante 14 optou por responder sobre os dois países, mas, quando marcou a opção entre parênteses só se referiu ao Canadá, indicando à parte os itens referentes ao Brasil.

1 - Em termos de linguagem, em seu país, para comunicar um falecimento:

( 4) usam-se expressões com a preocupação de abrandamento. Ex.: Descansar, Passar, Fazer a passagem, Falecer, Pass away, Estar desaparecido. 


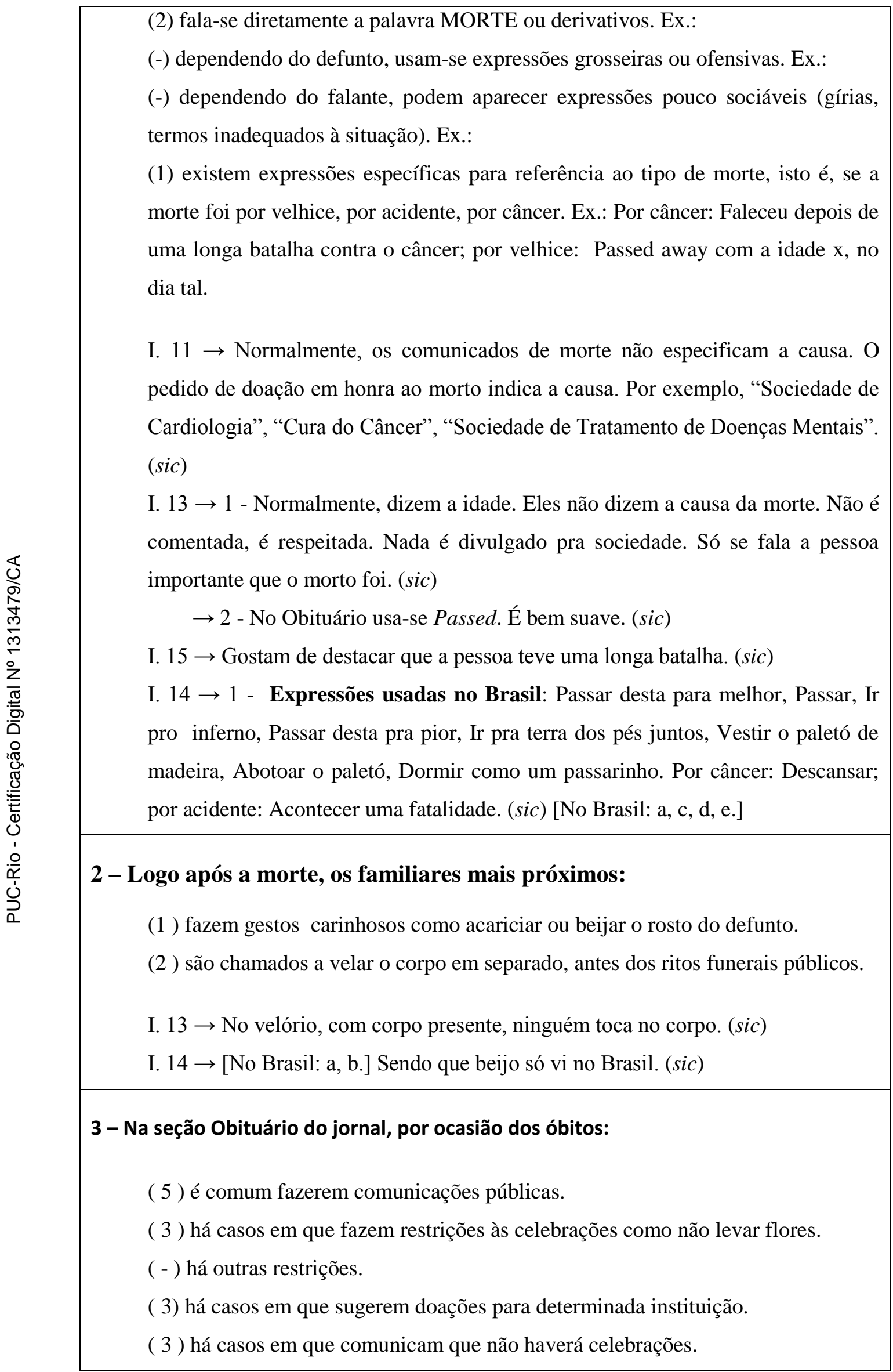


(2) há outros meios e/ou casos.

I. $13 \rightarrow 1$ - Não é obrigado porque é caríssimo. Umas 50 palavras custa em torno de dois mil dólares. Com fotografia é mais caro. Fora o anúncio no jornal, todos os outros itens são providenciados pelas entidades funerárias. Eles imprimem o atestado de óbitos. É um outro business. Você só escolhe, e eles tomam conta de tudo e te mandam a conta. (sic)

$\rightarrow 2$ - As instituições a que a pessoa pertencia também divulgam a morte. (sic)

I. $14 \rightarrow$ No Canadá, fazem a comunicação pública por jornal. No funeral, tem uma lista de convidados. Só entram os convidados para a recepção do funeral. Há casos em que pedem doações pra determinadas instituições. Às vezes, direcionam o convite só para os familiares. O meu patrão, quando a mãe dele faleceu, pediu pra, em vez de levar flores, fazer uma doação pra instituição do câncer, em nome dela. No Brasil, usam a mídia social e o boca a boca. (sic)

I. $15 \rightarrow$ e-mail

4 - Nos funerais, em seu país, encontram-se os seguintes itens:

( 3) velas; ( 4) flores; ( 3 ) música; (2) comida; (1 ) café; (1) chá; (1) outros.

I. $12 \rightarrow$ Só há velas quando os funerais são nas igrejas, mesmo assim, elas são acessas com controle remoto. Para se evitar um acidente, não têm sido usadas velas com chamas de fogo. A música pode ser ao vivo, ou não. (sic)

I. $13 \rightarrow$ No memorial service, na funerária, numa sala, ao lado da sala da visitação do corpo, tem comida e bebida. Nas mesas onde as pessoas sentam, conversam, tomam drinque, tem flores. Na igreja católica, após o enterro, o pessoal volta pra igreja, aí tem como se fosse uma festa, com tudo quanto é tipo de comida, tudo quanto é tipo de bebida. (sic)

I. $14 \rightarrow$ Em Goiânia, tem cânticos religiosos. As pessoas chegam famintas. Sempre tem que ter pão com manteiga, café, feijão, arroz, carne, salada. Lá, tem os cinco itens iniciais. (sic)

$\rightarrow$ Aqui, no Canadá, tem sempre uma pessoa para direcionar os convidados, e tem garçons. Tudo é muito organizado. (sic)

I. $15 \rightarrow$ Nos dois funerais em que eu fui, havia objetos pessoais do morto, como livros e peças de roupa. (sic) 


\section{5 - As frases escritas nas faixas das coroas de flores:}

( 1 ) trazem mensagem padrão, cumprem formalidades. Ex.: Descanse em paz

( - ) têm cunho particular, emocional. Ex.: Saudades de seus filhos e netos

( 3 ) Não se aplica. Especifique: Não se usam coroas de flores nos funerais aqui.

As flores são arrumadas em buquês. (sic)

I. $14 \rightarrow$ Em Goiânia, as mensagens são padrão. (sic)

I. $15 \rightarrow$ Não é comum aqui, mas em um dos funerais tinha uma coroa. (sic)

6 - No funeral, os familiares mais chegados:

( 3) não choram em público.

( 4 ) choram de forma bastante contida.

( - ) choram sem pudores, extravasando seus sentimentos.

( 1) dão vazão aos sentimentos de forma mais ou menos contida, dependendo de alguma circunstância ou característica.

I. $13 \rightarrow$ Quando expressam a emoção, desce uma lágrima, e eles pedem desculpas. (sic)

I. $14 \rightarrow$ No Brasil, choram sem pudores, extravasando seus sentimentos. (sic)

I. $15 \rightarrow$ Expressavam sentimentos na parte dos discursos em que as pessoas falavam sobre a morta. ( sic)

\section{7 - Onde você mora, na hora dos cumprimentos, há:}

(1 ) apenas palavras. Ex.: Sinto muito pela perda, Lamento pela perda, Meus sentimentos.

(4) palavras e gestos formais como aperto de mãos. Ex.:

(4) palavras e gestos afetuosos como abraço. Ex.:

( - ) apenas abraço.

( - ) outros.

I. $14 \rightarrow$ Em Goiânia, tem palavras e gesto afetuosos como abraço, ou apenas abraço bem demorado. No Canadá, palavras com aperto de mãos. (sic)

8 - Quando há a celebração da vida do ente querido, com comes e bebes, após o funeral ou o enterro, os lugares possíveis para esse evento são: 
(3) a casa dos familiares ou de amigos;

(5) um espaço na casa funerária;

(4) um salão na igreja;

( - ) um restaurante;

( 2 ) uma casa de festas;

(1) um hotel de luxo; outros.

9 - São convidados a participar dessa cerimônia.

( 2 ) apenas os familiares;

(3) familiares e amigos somente;

( 3) familiares, amigos e demais convíveres sociais (vizinhos, colegas de trabalho);

( 4 ) um religioso da religião do morto;

( 2 ) todas as pessoas conhecidas do morto, independente do grau de intimidade.

I. $12 \rightarrow$ Quando a pessoa que faleceu morava numa casa de idosos, há casos em que todos os funcionários dessa casa são convidados, pois foram as últimas com quem conviveu. (sic)

I. $15 \rightarrow$ Com certeza, tem sempre um religioso. (sic)

10 - Nessa reunião festiva:

( 5 ) as pessoas se vestem formalmente.

( 3 ) algumas pessoas comparecem em trajes informais, dependendo do ambiente.

( 1 ) algumas pessoas comparecem em trajes típicos regionais.

I. $12 \rightarrow$ Como a celebração da vida é logo após o funeral, as pessoas vão direto, com a mesma roupa, em geral, de cor escura. Atualmente, algumas pessoas estão usando cores mais alegres. (sic)

I. $14 \rightarrow$ Nas cores escuras: preta, cinza escuro, azul marinho, marrom.

11 - Seu país, com o grande número de imigrantes que acolhe, mantém a tradição do ritual de passagem funeral e de celebração da vida?

( 5) sim; ( - ) não. 


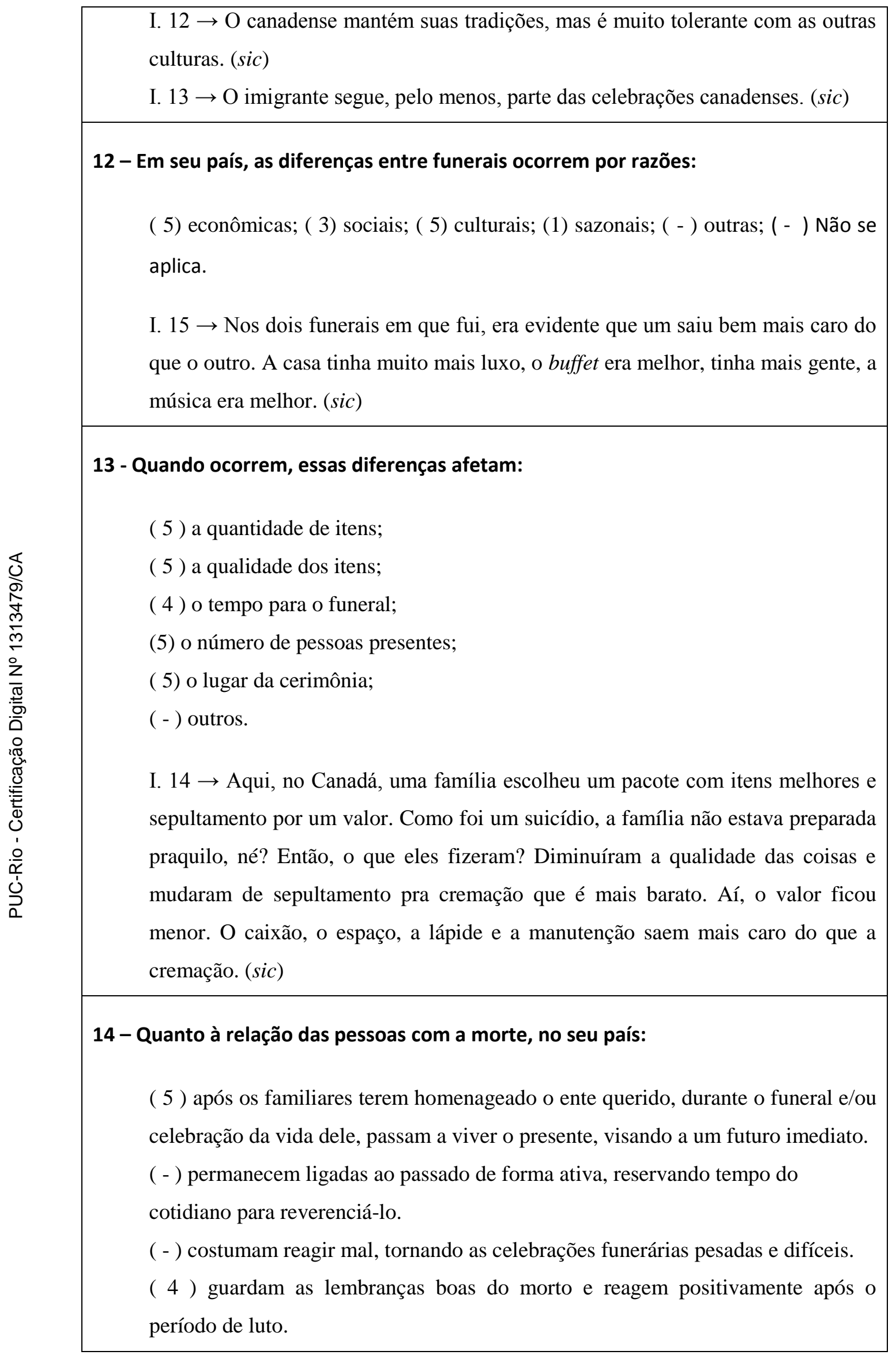




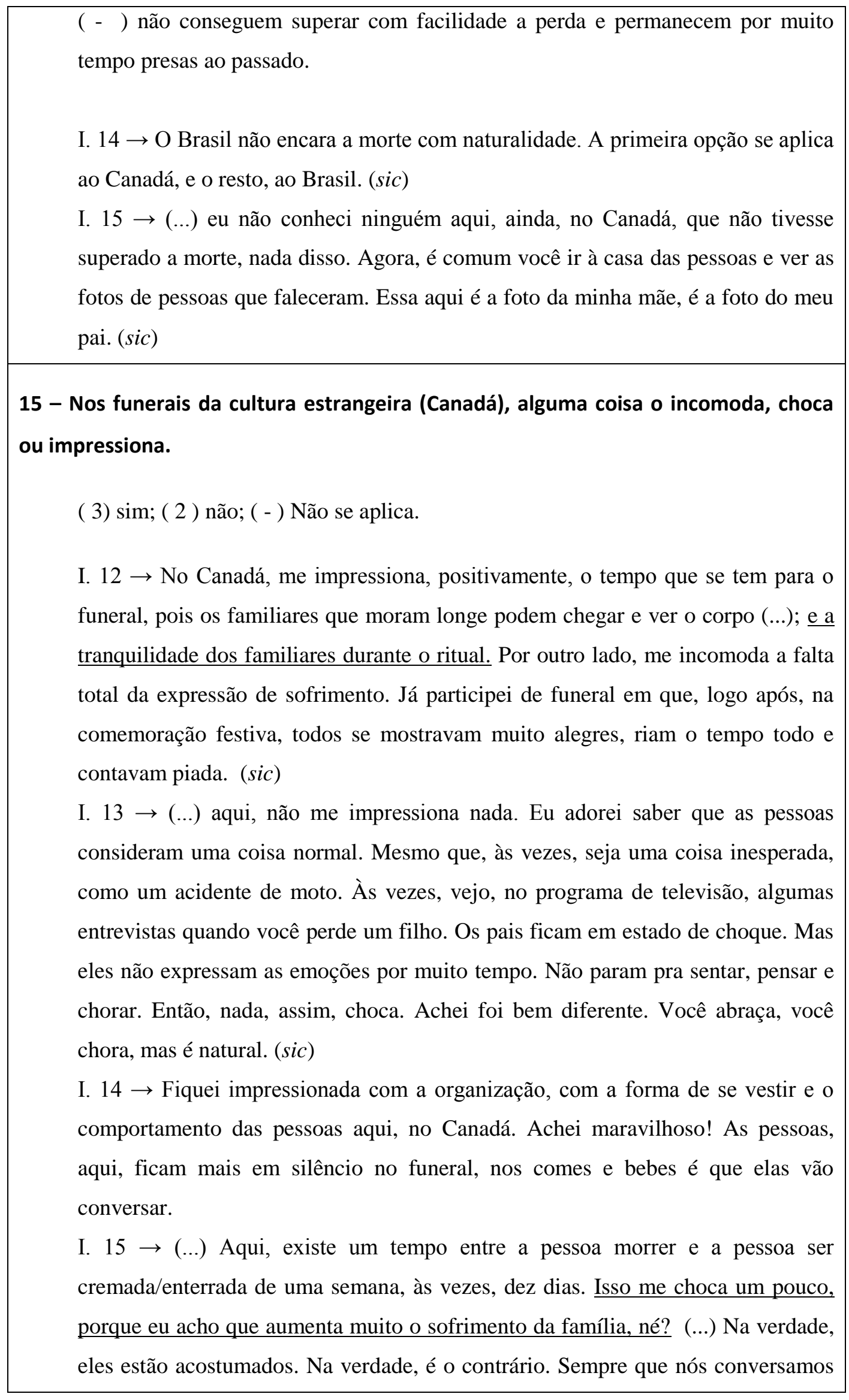


sobre isso aqui, no Canadá, eles dizem: "Poxa, parece que vocês querem se livrar do morto rápido!”. (...) Mas o contrário também acontece. Sempre que digo que no Brasil o tempo é de 24 horas, eles se chocam.(...) (sic)

Os dados apontados por brasileiros que moram no Canadá, quanto à relação das pessoas com a morte, corroboram o pensamento de DaMatta de que, na sociedade brasileira, mantém-se um vínculo entre o mundo real e o outro mundo (Cf. 2.1.4.1.3), pois, por não encararmos a morte com naturalidade, permanecemos ligados ao passado de forma ativa, reservando tempo do cotidiano para reverenciar o morto, costumamos reagir mal à morte, tornando as celebrações funerárias pesadas e difíceis; não conseguimos superar com facilidade a perda, permanecendo por muito tempo presos ao passado. Já os canadenses, após terem homenageado o ente querido, durante o funeral e a celebração da vida do falecido, passam a viver o presente, visando a um futuro imediato, podendo, assim, guardar as lembranças boas dele e reagir positivamente após o período de luto. Esses comportamentos revelam a emotividade dos brasileiros e o pragmatismo dos canadenses, ratificando as respectivas culturas multiativa e ativo-linear.

Os noruegueses agem como os nascidos no Canadá, mas, quando não se trata de morte por velhice ou por câncer, os dois países de cultura ativo-linear podem ter um outro comportamento menos pragmático ou até mesmo emotivo, como se depreende da comparação das respostas dadas à questão 14 nos Quadros 8 e 9 apresentados anteriormente, nos quais, tanto para o informante 01, canadense, quanto para o informante 09, norueguês, algumas perdas específicas como a de crianças, jovens ou alguém muito chegado são afetivamente mais difíceis.

Curiosamente, se essa informação parece contradizer a teoria das culturas ativolineares, o relato da informante 19 para a questão 14 do Quadro 11, a seguir, contrapõe o que comumente se diz do comportamento excessivamente emotivo dos brasileiros diante da morte. Ali encontramos dados que apontam a resignação de pessoas extremamente religiosas nas expressões utilizadas no Brasil como Foi o que Deus quis, Chegou a hora dele. 
Para trabalhar os dados referentes aos brasileiros que vivem ou viveram na Noruega, foram compiladas, no Quadro 11, as respostas coletadas desse grupo de entrevistados.

Quadro 11 - Compilação das respostas do Questionário da segunda etapa da coleta de dados brasileiros na Noruega

\begin{tabular}{|l|l|}
\hline Nacionalidade: Brasileira & $\begin{array}{l}\text { Identificação dos Informantes: } \\
\mathbf{1 6 , 1 7 , 1 8 , 1 9 , 2 0}\end{array}$ \\
\hline $\begin{array}{l}\text { Obs.: Os informantes 16, 17, 18 e } 20 \text { tiveram como referente a Noruega. A informante } \\
19 \text { optou por falar dos dois países, mas, quando marcou a opção entre parênteses só se } \\
\text { referiu à Noruega, indicando à parte os itens referentes ao Brasil. }\end{array}$
\end{tabular}

1 - Em termos de linguagem, em seu país, para comunicar um falecimento:

( 3) usam-se expressões com a preocupação de abrandamento. Ex.: Descansa, Olha, eu sinto muito, mas ele acaba de falecer.

(4) fala-se diretamente a palavra MORTE ou derivativos. Ex.:

( - ) dependendo do defunto, usam-se expressões grosseiras ou ofensivas. Ex.:

( -) dependendo do falante, podem aparecer expressões pouco sociáveis (gírias, termos inadequados à situação). Ex.:

( 5) existem expressões específicas para referência ao tipo de morte, isto é, se a morte foi por velhice, por acidente, por câncer. Ex.: Por doença e velhice: Ele descansou, foi melhor assim; Por acidente: Ele morreu, puxa, foi trágico, Foi tirado de nós bruscamente; Por velhice: Ele viveu uma vida muito rica, Dormiu para sempre, Adormeceu tranquilamente pra sempre; No caso de criança ou por acidente: Morreu rapidamente, Perdemos nosso querido; Por suicídio, o policial fala: Ele acaba de falecer.

I. $19 \rightarrow 1$ - Em Tocantins: desocupou a vaga, bateu as botas, deu a vaga pra outro. (sic)

$\rightarrow 2$ - Na Noruega, é comum eles usarem pastores para avisar sobre uma morte inesperada. Ele inicia com "Sinto muito, mas o seu familiar faleceu". (sic)

$\rightarrow 3$ - No Brasil, se a família é espírita, fala-se que a pessoa desencarnou. (sic)

I. $20 \rightarrow$ As pessoas são muito formais e tendem a ser muito diretas. Elas não utilizam eufemismo como se usa no Brasil, mas sempre usam uma expressão 
atenuante. Nunca ouvi termos chulos, vulgares, piadas.

\section{2 - Logo após a morte, os familiares mais próximos:}

( 4 ) fazem gestos carinhosos como acariciar ou beijar o rosto do defunto.

( 4 ) são chamados a velar o corpo em separado, antes dos ritos funerais públicos.

I. $16 \rightarrow$ No hospital onde meu irmão faleceu, Hospital Central de Álessund, no subsolo, há um espaço onde os corpos permanecem, até o dia do funeral, em salas hiper-refrigeradas, à disposição dos visitantes, com hora marcada. $\mathrm{O}$ familiar que chegar de fora pode entrar em contato com a casa funerária que eles providenciam a exposição do corpo.

I. $19 \rightarrow$ As pessoas acariciavam, mas ninguém beijou. Já em Tocantins, amigas de minha mãe, beijaram o rosto dela.

\section{3 - Na seção Obituário do jornal, por ocasião dos óbitos:}

(5) é comum fazerem comunicações públicas.

(3) há casos em que fazem restrições às celebrações como não levar flores.

(2) há outras restrições.

( 3 ) há casos em que sugerem doações para determinada instituição.

( 2 ) há casos em que comunicam que não haverá celebrações.

( 4 ) há outros meios e/ou casos.

I. $16 \rightarrow 1$-A casa funerária cobra tudo no mesmo pacote, inclusive, a publicação na seção obituário do jornal local. Normalmente, os anúncios são do mesmo tamanho.

$\rightarrow 2$ - Na morte do meu irmão, publicamos: "Em vez de flores, podem fazer uma contribuição para a instituição do câncer”. Aí, na igreja, na entrada, quando eles assinaram o livro de presença da igreja, depositaram a doação numa urna. Um agente da funerária abre a urna, conta o dinheiro e o envia para a instituição que nos envia uma mensagem de agradecimento pela contribuição, mencionando o valor recebido. Há pessoas que fazem o depósito direto na conta da instituição. (...) (sic)

$\rightarrow 4$ - Podem também divulgar pós-morte: "Foi enterrado em todo silêncio, com a participação só da família mais chegada." (sic)

I. $19 \rightarrow 1$ - Um amigo nosso morreu recentemente, e foi publicado que, em vez de flores, presenteassem a esposa e os filhos com uma viagem. (sic) 
$\rightarrow 2$ - Além do jornal, podem enviar e-mail, ou telefonar, mas o jornal é o principal meio. $\mathrm{O}$ folhetim da igreja também divulga. (sic)

Obs: I. $17 \rightarrow$ Jovens já estão usando o Facebook. Mas não é de praxe. (sic)

$\rightarrow 2$ - Uma amiga que morreu de câncer não queria que outras pessoas soubessem de sua morte. Não houve anúncio no jornal. (sic)

4 - Nos funerais, em seu país, encontram-se os seguintes itens:

( 5) velas; ( 5 ) flores; ( 5 ) música; ( 1) comida; (1 ) café; (1 ) chá; ( 5 ) outros.

I. $16 \rightarrow$ Quem quiser, pode fazer um discurso. A Igreja Luterana é junto com o Estado. Não é um Estado laico. São cantadas duas músicas tradicionais religiosas e outras que escolhemos com a funerária. Qualquer tipo de música. (sic)

I. $17 \rightarrow$ Há também livro de assinaturas e o programa. (sic)

I. $19 \rightarrow 1$ - músicos, foto do falecido, folheto com as letras da música, um texto sobre o falecido e passagem da bíblia. Tem no mínimo oito coroas de flores. As pessoas mais jovens ganham mais coroas. (sic)

$\rightarrow 2$ - Em Tocantins, no funeral de um amigo que era festeiro e músico, fizeram uma grande festa no funeral dele. Os amigos da umbanda rodearam o caixão, fizeram uma dança, tocaram música, falaram poesia. Na hora do enterro, tocaram tambores. (sic)

$\rightarrow 3-(\ldots)$ Antes, em Tocantins, tinha velas e flores em todos os funerais. Hoje, os cristãos pentecostais não aceitam velas nem flores. Lá, tem café, chá, almoço, janta, lanche da tarde. É normal a casa ficar aberta. A funerária oferece uma placa luminosa onde está escrito: Família em luto. A gente pendura na porta da sala. A casa fica toda aberta, portas e janelas. Quem quiser pode entrar. Lá, não tem muro. Colocam músicas que a pessoa gostava. Mas isso não é comum, não. (sic)

\section{5 - As frases escritas nas faixas das coroas de flores:}

( 5) trazem mensagem padrão, cumprem formalidades. Ex.: Sentiremos saudades, O último adeus, de (nomes)

(4) têm cunho particular, emocional. Ex.: Você virou uma estrela, Você é um anjo que vai nos proteger, Sentiremos saudades, Obrigada por tudo, Minha querida mãe/ Meu querido pai, saudades, Você deixa saudades, Você é amado por nós, Te amamos muito, Vamos sentir saudades. Escrevem também alguns versos, salmos, 


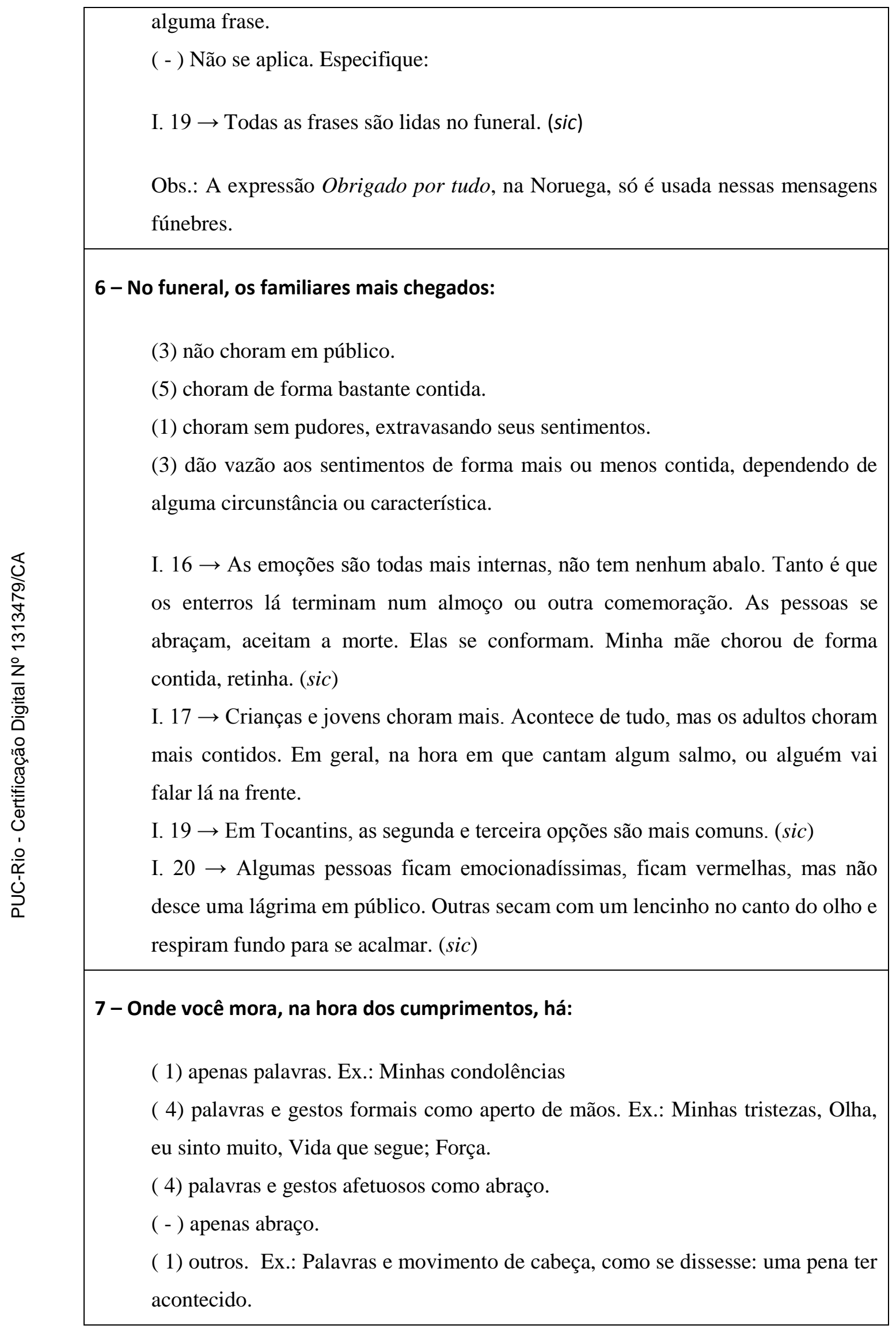


I. $19 \rightarrow$ No Brasil, podem ser a $2^{\mathrm{a}}$, a $3^{\mathrm{a}}$ e a $4^{\mathrm{a}}$. (sic)

8 - Quando há a celebração da vida do ente querido, com comes e bebes, após o funeral ou o enterro, os lugares possíveis para esse evento são:

(4) a casa dos familiares ou de amigos;

( 1) um espaço na casa funerária;

( 5) um salão na igreja;

(3) um restaurante;

( 3) uma casa de festas;

( 1 ) um hotel de luxo;

(2) outros.

I. $17 \rightarrow$ Casa de amigos, não. No hotel, é raro, mas, se tiver muitos hóspedes que vieram pro enterro em um determinado hotel, pode ser. Podem, também, ir pra um bar beber cerveja, o que eles chamam de beber o defunto. Então, falam sobre o morto, você faz memória. (sic)

\section{9 - São convidados a participar dessa cerimônia.}

(1) apenas os familiares;

(3) familiares e amigos somente;

(4) familiares, amigos e demais convíveres sociais (vizinhos, colegas de trabalho);

( - ) um religioso da religião do morto;

(2) todas as pessoas conhecidas do morto, independente do grau de intimidade.

I. $16 \rightarrow$ Se for logo em seguida ao funeral, acho que todos são convidados, mas se for uma coisa muito depois, a família pode selecionar os convidados. Lá, é uma coisa bem aceita. No convite para o enterro diz: "Depois, receberemos para tal lugar.". (sic)

I. $17 \rightarrow$ Nunca vi um padre nessa cerimônia. Pode ser que tenha algum religioso de outra religião. Da minha, que é católica, nunca vi. (sic)

I. $19 \rightarrow 1$ - Na Noruega, quando anunciam a morte no jornal, já colocam o que vai ter. Aí, quem vai ao funeral vai pra essa cerimônia. ( sic)

10 - Nessa reunião festiva:

( 5 ) as pessoas se vestem formalmente. A maioria veste preto. 


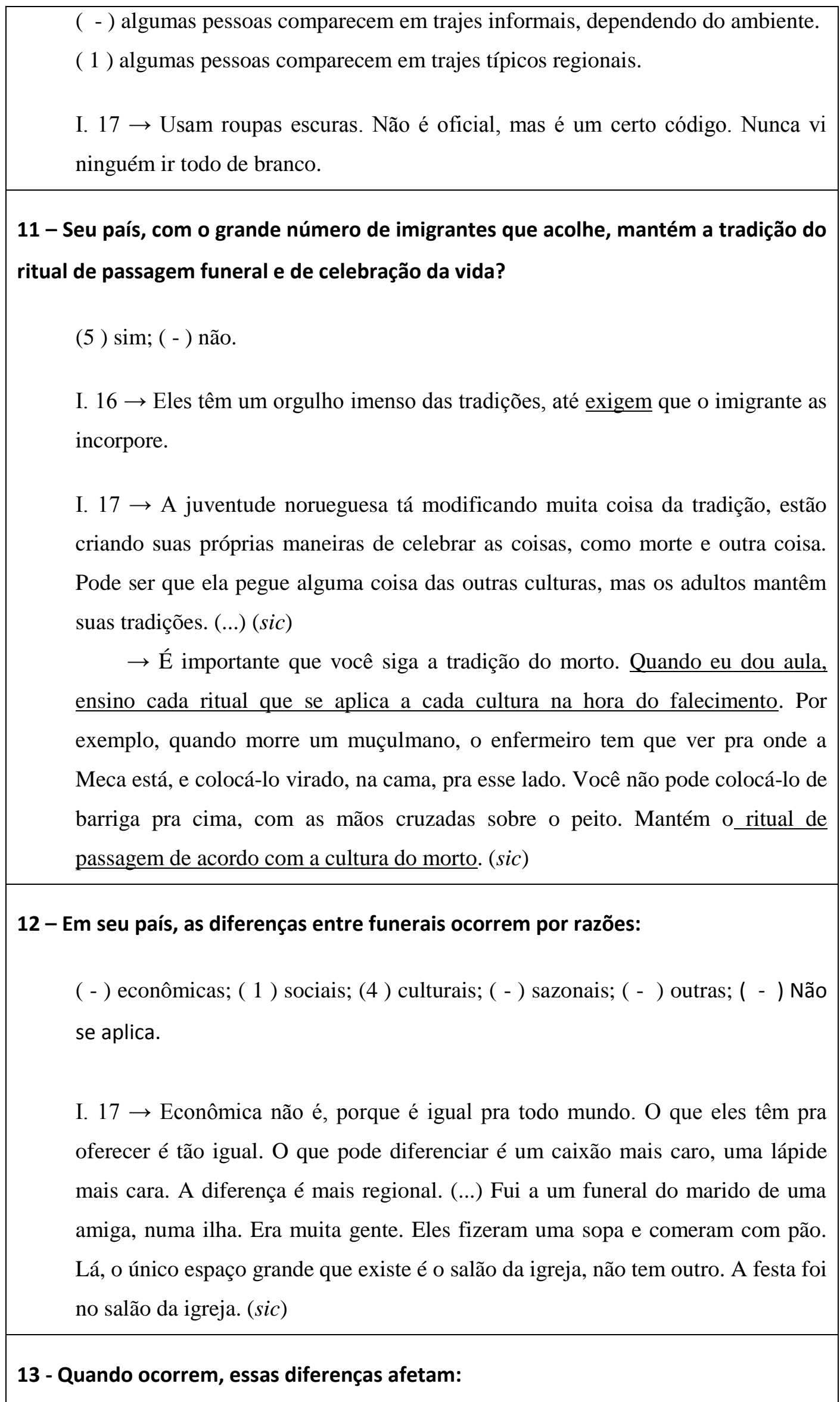


( - ) a quantidade de itens;

( 2 ) a qualidade dos itens;

( 2 ) o tempo para o funeral;

( 4 ) o número de pessoas presentes;

( 4 ) o lugar da cerimônia;

( - ) outros.

I. $16 \rightarrow$ Quem decide a quantidade de itens do funeral é o religioso responsável. Por isso, os funerais são muito parecidos. ( sic)

I. $20 \rightarrow$ Costuma ser um tempo mais longo, pois muitos falam sobre o falecido. (sic)

14 - Quanto à relação das pessoas com a morte, no seu país:

( 3 ) após os familiares terem homenageado o ente querido, durante o funeral e/ou celebração da vida dele, passam a viver o presente, visando a um futuro imediato. ( 1 ) permanecem ligadas ao passado de forma ativa, reservando tempo do cotidiano para reverenciá-lo.

( - ) costumam reagir mal, tornando as celebrações funerárias pesadas e difíceis.

( 5 ) guardam as lembranças boas do morto e reagem positivamente após o período de luto.

( 2 ) não conseguem superar com facilidade a perda e permanecem por muito tempo presas ao passado.

I. $16 \rightarrow$ Eles aceitam as coisas muito bem. É cultural, a vida continua. Eles superam com facilidade.

I. $17 \rightarrow$ O primeiro representa bem, mas há umas pessoas que ficam tão ligadas ao passado que entram em depressão. Ficam de licença médica por tempo indeterminado, recebendo integralmente do empregador, por três meses (...). (sic) I. $18 \rightarrow$ Em caso de morte por velhice, passam a viver o presente, visando o futuro. Acidentes são raros, e neste caso não superam a perda. (sic)

$\rightarrow 2$ - Em Palmas, o pessoal é muito resignado. Ele segue em frente. Segue os ditados: Foi o que Deus quis, Chegou a hora dele, Era o dia de morrer, Estava nos planos de Deus. A morte no Brasil é muito comum. Os pobres têm tremedeira, passam mal, desmaiam no caixão. (sic) 
15 - Nos funerais da cultura estrangeira (Noruega), alguma coisa o incomoda, choca ou impressiona.

( 5 ) sim; ( - ) não; ( - ) Não se aplica.

I. $16 \rightarrow(\ldots)$ A cultura, lá [NO], ajuda por conta do social. Fora isso, o funeral e o enterro ocorrem de forma muito profissional. Você só escolhe o que quer, e o serviço funerário providencia tudo. Tudo corre com muito respeito para qualquer pessoa. Quando você chega, já está tudo pronto, tudo aberto. (sic)

I. $17 \rightarrow$ Me impressionou foi a tranquilidade, que é uma cerimônia, assim, até muito bonita. A cerimônia é feita na igreja ou no crematório, é, assim, é muito digna. Aí, me impressionou bastante. Foi bem calmo, bonito, órgão tocando. O que eu fiquei .primeiro funeral que fui aqui, fui muito bem vestida e me senti mais numa festa. Você conversa com todo mundo, fala sobre o morto. Nada me chocou. (sic)

I. $18 \rightarrow$ Todo mundo canta afinado, mesmo canções difíceis. (sic)

I. $19 \rightarrow$ O que acho bom lá [NO] é o tempo que a pessoa tem para preparar as coisas, também, a igualdade no cemitério. Independente da classe social, todos têm uma placa com o nome, data de nascimento e de morte, e alguma frase que o familiar deixa, um lugarzinho para colocar velas e outro para colocar flores. No Brasil, a desigualdade existe até no cemitério. (...) (sic)

I. $20 \rightarrow$ Até hoje é um mistério pra mim o autocontrole. Eu gostaria de aprender isso com eles. Como eles conseguem ter um controle tão grande e passar uma determinada serenidade. Eu fico chocada positivamente. Isso me impressiona muito. (sic)

Nesse Quadro, chamamos atenção para a questão 11. Referindo-se ao fato de a Noruega manter a tradição do ritual de passagem funeral e de celebração da vida, a informante 16 justifica cabalmente a unanimidade das respostas sim, pois, diferente do que ocorre nas demais culturas, ela afirma que no país "até exigem" que os imigrantes incorporem as suas. Cabe aqui recuperar dados da análise do Canadá, Quadro 10, para mostrarmos que esses dois países de cultura ativo-linear, no ponto de vista de informantes brasileiros, convergem no que se refere à manutenção das respectivas tradições, mas afastam-se quando imigrantes 
brasileiros revelam o egocentrismo norueguês, e brasileiros no Canadá, a tolerância canadense, corroborando as respectivas características que Lewis já havia constatado nessas duas nações. É interessante notar que os informantes imigrantes na Noruega têm as mesmas impressões dos donos da casa em relação a si mesmos e ao modo como sua cultura lida com os rituais pós-morte. Ao mesmo tempo que brasileiros imigrantes admitem que o canadense "é muito tolerante com outras culturas" (I.12), também reconhecem, como a informante 13, que "O imigrante é que segue (...)” a cultura local, não só pelo respeito à terra que o acolhe, como também como forma de ser mais bem aceito naquele lugar. Isso vai ao encontro de como Lewis acha que se deve estabelecer empatia com os canadenses, espelhando-se em seus típicos valores de tolerância, calma, razoabilidade, expressões e comportamento discretos, pois, embora eles não sejam muito nacionalistas, gostam de ter sua identidade nacional apreciada pelo estrangeiro (Cf. 2.1.3.2.2). Pode-se afirmar que aos olhos desses brasileiros, a Noruega e o Canadá são países que preservam inquestionavelmente suas tradições, tal como eles próprios responderam à pergunta 11 .

$\mathrm{Na}$ questão 12, é interessante observar que, quanto às razões por que ocorrem diferenças entre os funerais na Noruega, houve uma polarização de respostas em torno de apenas duas opções: sociais e culturais, sendo que a maioria marcou a segunda. Diferente dos outros grupos representados nos Quadros de 8 a 10, ninguém marcou a opção econômicas.

Neste momento, cabe trazermos para reflexão os significados de funeral: (i) cerimônia de enterramento; enterramento, enterro (Aurélio: 1997); (ii) Conjunto das cerimônias de sepultamento (HOUAISS: 2012). Terminado o funeral, o caixão com o corpo é enterrado ou cremado.

Nossa hipótese inicial previa o significado metonímico do conjunto das cerimônias pós-morte, porque é assim que se usa no Brasil. No Canadá, e na Noruega, essas cerimônias são bem demarcadas. De acordo com os dados encontrados, wake ou velório é a cerimônia em que o corpo é posto em exposição, permitindo que parentes e convidados, ou só familiares, possam honrar a memória do falecido antes do funeral. Sua duração é de uma a duas horas. E funeral é a cerimônia religiosa, com flores, velas, músicas, discursos, folhetos com letras de cânticos e orações, exposição de fotos e o caixão está lacrado. Após essa 
cerimônia, realiza-se o sepultamento ou a cremação. No Brasil, é comum empregarmos as palavras enterro, funeral, sepultamento e até velório, metonimicamente, como se estivéssemos usando sinônimos para essas cerimônias.

Diante disso, voltamos à polarização das respostas e podemos afirmar que o grupo do Quadro 11 respondeu tendo em vista o significado da cerimônia religiosa, ou que consideraram os fatos de o funeral ser diretamente ligado à Igreja, já estando coberto pelos impostos que pagam ao Estado (I.16); e de os cemitérios serem, como no Canadá, como campos com lápides parecidas, embora haja diferença de preços por conta da qualidade do material com que elas são feitas (I.13).

Nos outros Quadros, houve maior escolha de razões econômicas e culturais, seguidas de sociais, e grande parte dos canadenses optou também por razões sazonais. Certamente, houve nesses grupos quem considerasse o sentido metonímico da palavra funeral, o que se comprova em seus relatos, em que encontramos registro dos termos sepultamento e funeral na mesma frase do informante 12.

A seguir estão compiladas, no Quadro 12, as respostas coletadas da informante brasileira cuja experiência com funerais se restringe ao Brasil.

Quadro 12 - Compilação das respostas do Questionário da segunda etapa da coleta de dados brasileira não imigrante

Nacionalidade: Brasileira $\quad$ Identificação do Informante: 21

1 - Em termos de linguagem, em seu país, para comunicar um falecimento:

( $\mathrm{x}$ ) usam-se expressões com a preocupação de abrandamento. Ex.: Falecer, Descansar, Fenecer, Entregar a alma ao Salvador, Dar o último suspiro, Ir para o céu, Voltar para o Pai, Ir para a casa do Pai.

( $\mathrm{x}$ ) fala-se diretamente a palavra MORTE ou derivativos.

( $\mathrm{x}$ ) dependendo do defunto, usam-se expressões grosseiras ou ofensivas. Ex.: Bater com o rabo na cerca, Ir comer capim pela raiz.

( $\mathrm{x}$ ) dependendo do falante, podem aparecer expressões pouco sociáveis (gírias, termos inadequados à situação). Ex.: Abotoar o paletó, Bater as botas, Já era.

( - ) existem expressões específicas para referência ao tipo de morte, isto é, se a 
morte foi por velhice, por acidente, por câncer.

\section{2 - Logo após a morte, os familiares mais próximos:}

( $\mathrm{x}$ ) fazem gestos carinhosos como acariciar ou beijar o rosto do defunto.

( - ) são chamados a velar o corpo em separado, antes dos ritos funerais públicos.

3 - Na seção Obituário do jornal, por ocasião dos óbitos:

( x ) é comum fazerem comunicações públicas.

( x ) há casos em que fazem restrições às celebrações como não levar flores.

( x ) há outras restrições.

( - ) há casos em que sugerem doações para determinada instituição.

( - ) há casos em que comunicam que não haverá celebrações.

( x ) há outros meios e/ou casos.

I. $21 \rightarrow$ Há famílias que dispensam os cumprimentos. Internet (e-mail, Facebook, WhatsApp etc) (sic)

4 - Nos funerais, em seu país, encontram-se os seguintes itens:

( x ) velas; ( x ) flores; ( x ) música; ( - ) comida; ( - ) café; ( - ) chá; ( - ) outros.

I. $21 \rightarrow$ No meu estado não há cultura de celebração "festiva", mas já presenciei, em Minas Gerais, velórios com comes e bebes. (sic)

\section{5 - As frases escritas nas faixas das coroas de flores:}

(x) trazem mensagem padrão, cumprem formalidades. Ex.: Descanse em Paz, Homenagem dos colegas de tal lugar, Saudades eternas de...

( $\mathrm{x}$ ) têm cunho particular, emocional. Ex.: Parentes e/ou amigos íntimos optam por escrever alguma coisa que se refira a momentos significativos vividos em comum.

I. $21 \rightarrow$ É comum que, nas floriculturas próximas aos cemitérios, haja cadernos com frases prontas como sugestão. Também, usa-se escolher frases feitas de autores famosos ou trechos de letras de música. (sic) 
6 - No funeral, os familiares mais chegados:

( - ) não choram em público.

( - ) choram de forma bastante contida.

( - ) choram sem pudores, extravasando seus sentimentos.

( x ) dão vazão aos sentimentos de forma mais ou menos contida, dependendo de alguma circunstância ou característica.

I. $21 \rightarrow$ A extravasação dos sentimentos, em geral, tem relação direta com a educação das pessoas. Pessoas com menos nível de educação tendem a extravasar livremente seus sentimentos; já pessoas de nível sociocultural maior cultivam a discrição. (sic)

7 - Onde você mora, na hora dos cumprimentos, há:

( - ) apenas palavras.

( $\mathrm{x}$ ) palavras e gestos formais como aperto de mãos. Ex.: Meus sentimentos, Força, Sinto muito.

( x ) palavras e gestos afetuosos como abraço. Ex.: Conte comigo, Ele está com Deus, Ele descansou.

( $\mathrm{x}$ ) apenas abraço.

( $\mathrm{x}$ ) outros. Ex.: beijos

8 - Quando há a celebração da vida do ente querido, com comes e bebes, após o funeral ou o enterro, os lugares possíveis para esse evento são:

( $\mathrm{x}$ ) a casa dos familiares ou de amigos;

( - ) um espaço na casa funerária;

( - ) um salão na igreja;

( - ) um restaurante;

( - ) uma casa de festas;

( - ) um hotel de luxo; outros.

I. $21 \rightarrow$ Embora não seja comum, há algumas famílias que celebram, talvez, por influência cultural da família.

9 - São convidados a participar dessa cerimônia.

( - ) apenas os familiares; 


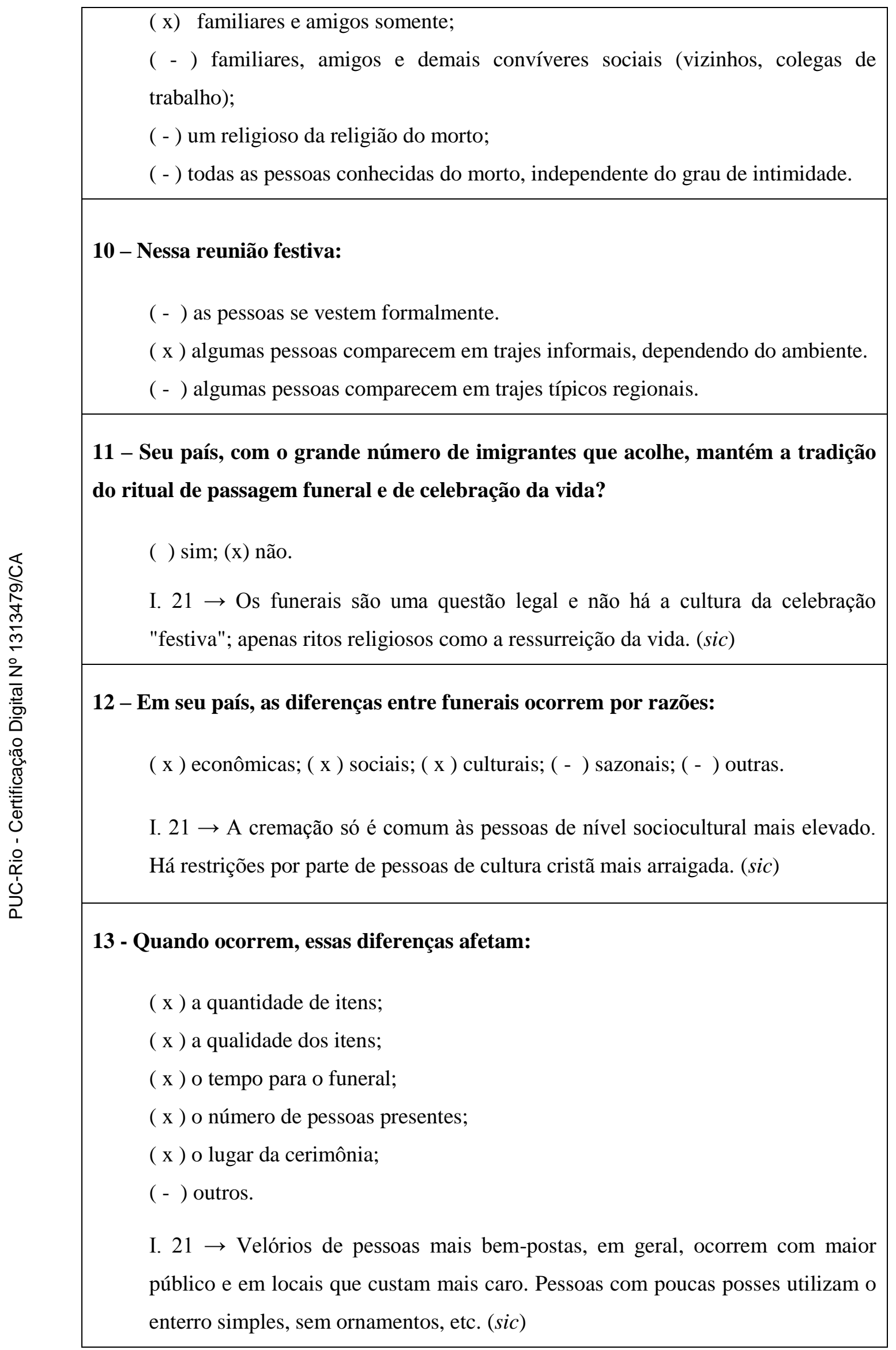




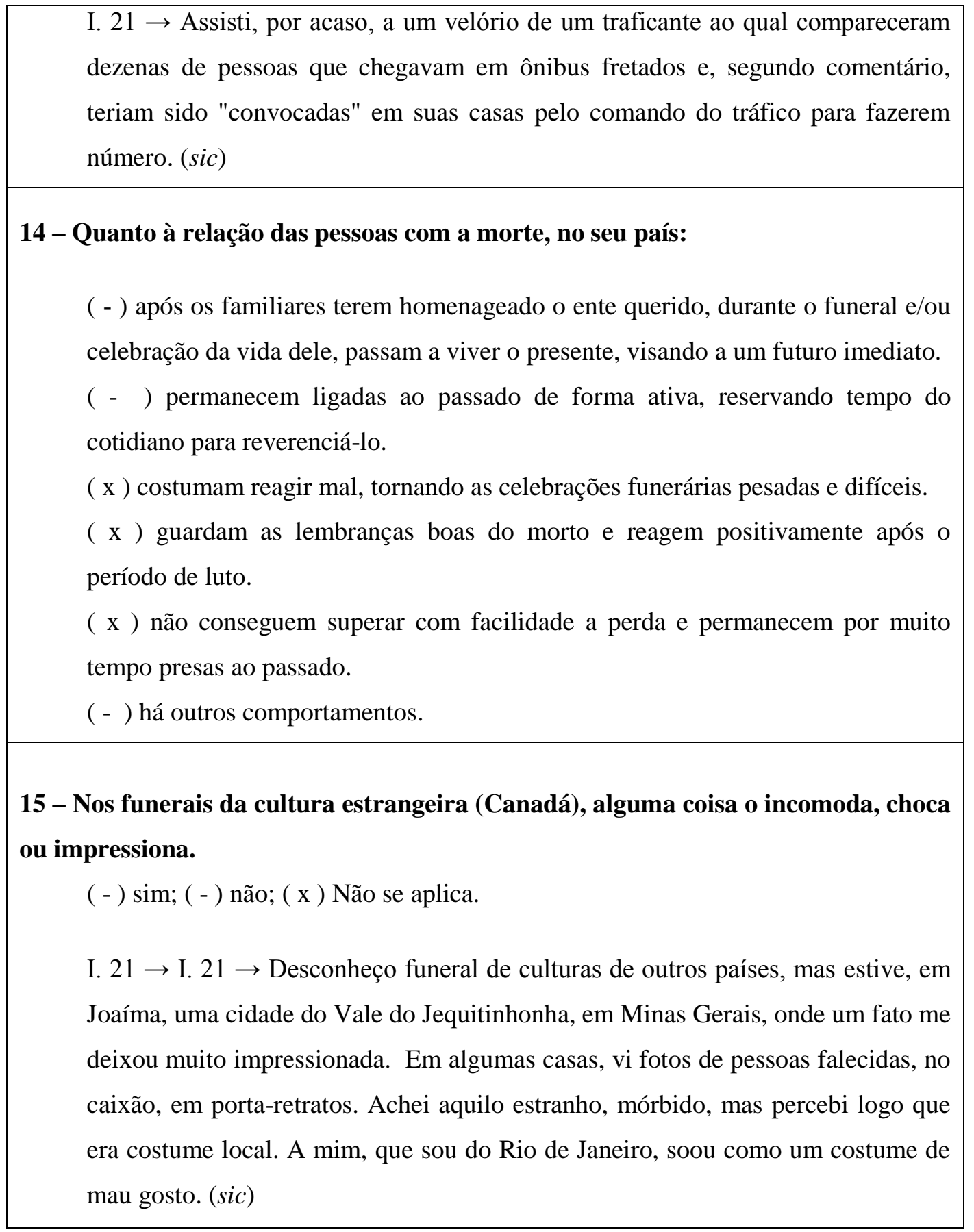

O Quadro 12 nos permite discutir alguns achados de relevância no campo da linguagem, como a observação da riqueza vocabular de que o brasileiro se serve para falar da morte, tanto com conotação positiva como negativa, sendo bastante mais numerosas as expressões que podemos ouvir na língua portuguesa sobre o tema. As respostas dadas pela informante corroboram a classificação de indiretividade atribuída ao Português.

Considerando as características culturais de nosso povo, da forma como o 
entende DaMatta (Cf. 2.1.4.1.1), as questões 1 e 5 se complementam nos dizeres da informante: o brasileiro utiliza expressões populares para falar da morte e, quando escreve, também lança mão da retórica e da literatura, fazendo-nos concluir que se trata de uma forma de valorização do rito, de manutenção da tradição, quando compreende que a situação requer formalidade e correção.

Além desse aspecto linguístico, a convencionalidade - ou falta dela -, no Brasil, também fica evidente nas questões $3,4,10,13$ e 15 . Se nos atentarmos às respostas assinaladas pela informante, vamos perceber que manter as tradições ou afastar-se delas sempre vai depender das circunstâncias que envolvem o funeral: o morto em si, suas posses, valores pessoais, profissionais e sociais, assim como o momento das celebrações, a assistência e o lugar do país onde isso se dá. Por exemplo, a informante registra, na questão 3, que hoje se usam as mídias sociais para comunicar falecimentos com mais constância que os tradicionais anúncios fúnebres publicados na mídia impressa. E, na questão 4, que há diferença entre "meu estado" [o Rio de Janeiro], onde "não há cultura de celebração festiva", e o estado de Minas Gerais, reconhecidamente mais conservador, onde os "velórios com comes e bebes" fazem parte da tradição das famílias.

Na resposta da questão 15 , podemos perceber que a entrevistada sofreu um choque intercultural em seu próprio país, ao se deparar com fotos de corpos em caixão expostas em porta-retratos em algumas casas, em outra cidadezinha de Minas Gerias, o que não é comum no Brasil. Por isso ela estranhou o fato, considerando-o "mórbido e de mau gosto". Nesse sentido, pelos dados, Brasil e Noruega convergem, uma vez que o informante 09, no Quadro 9, revelou ser um choque para ele fotografar o corpo dentro do caixão.

As respostas dessa informante às questões 4 e 15, e das informantes 14 e 19 à pergunta 4, ratificam Hall e Lewis quanto à existência de fortes variações regionais dentro de um país.

Por oposição aos conceitos dos estrangeiros informantes, a brasileira imputa o comportamento mais ou menos contido dos familiares e amigos nos velórios mais ao nível cultural das pessoas do que ao nível social, puramente. Ela ilustra sua resposta com exemplo de um velório de um traficante, ao qual supostamente compareceram pessoas com "menos educação" e que, por isso mesmo, deram mostras exageradas de sentimentos comuns a qualquer pessoa que 
sofreu uma perda.

Passando agora a triangular as experiências relatadas por canadenses, noruegueses e brasileiros, tem-se que, quanto à divulgação pública do falecimento, nos três países, há a publicação na seção Obituário do jornal impresso, sendo que, no Brasil, restringe-se a um pequeno grupo; no Canadá, estão passando, pouco a pouco, a usar o jornal online; e na Noruega, é muito comum, chega a quase cem por cento o número de publicações dos óbitos. Além desse meio de comunicação, o e-mail está sendo recorrentemente citado em todas as culturas, quer relacionado à juventude, quer como referência à intimidade; o fato é que a tecnologia vem aos poucos, se insinuando nas diferentes culturas e globalizando os costumes. Há também ocorrências em outras mídias sociais como citado na página 99.

Após verificarmos um a um esses quadros, identificamos duplas interpretações do mesmo fato apontado, e olhares contrários de brasileiros que moram em países de cultura ativo-linear onde observaram um funeral. O mesmo fato que impressiona positivamente uma brasileira que mora na Noruega incomoda seu conterrâneo que vive no Canadá: para a informante 20, no país nórdico, o autocontrole é algo digno de ser aprendido e replicado; ela fica "chocada positivamente". Por outro lado, o informante 12 diz que "incomoda a falta total da expressão de sofrimento" dos canadenses. Cabe lembrar que ambos são brasileiros imigrantes em países de culturas semelhantes, da mesma faixa etária, de modo que a observação passa mais pela bagagem cultural de cada um deles do que propriamente pelo impacto que as convencionalidades locais pudessem suscitar.

Em relação ao tempo que se leva para o funeral no Canadá, abordado na questão 15, mais uma vez, dois brasileiros o veem de modo bem distinto. Enquanto o informante 12 vê positivamente pelo lado dos planejamentos para as cerimônias e pela serenidade dos familiares, o outro, informante 15, enxerga o tempo de espera como um sofrimento para a família enlutada. Neste caso, inaceitável para os padrões de conduta brasileiros.

Por se tratar de uma diferença cultural, os canadenses também estranham e até se chocam com nosso tempo para o sepultamento, como foi visto anteriormente. Contrariamente ao informante 15, quando ele conversa sobre seu 
ponto de vista com alguém nascido no Canadá, lhe respondem: "Poxa, parece que vocês querem se livrar do morto rápido!".

Por fim, cabe informarmos que, embora tenhamos encontrado, em nossos dados, relatos de estranhamento de brasileiros em relação à cultura de funeral tanto no Canadá quanto na Noruega, a maioria de nossos compatriotas estão positivamente impressionados com o funeral nesses dois países. Comprovando de forma resumitiva, trazemos o seguinte relato encontrado no Quadro 11:

\section{17 (BR), Q. 15}

Me impressionou foi a tranquilidade, que é uma cerimônia, assim, até muito bonita. A cerimônia é feita na igreja ou no crematório, é, assim, é muito digna. Aí, me impressionou bastante. Foi bem calmo, bonito, órgão tocando. O primeiro funeral que fui aqui, fui muito bem-vestida e me senti mais numa festa. Você conversa com todo mundo, fala sobre o morto. Nada me chocou. No Brasil, já é aquela correria, todo mundo extravasando sentimentos, tudo no mesmo dia. (sic) [NO]

\subsection{Outros Achados Iconográficos}

Considerando o material iconográfico, as Figuras 5 e 6, escolhidas na Internet (Cf. Cap. 7), e uma foto cedida pela informante 17 (BR/NO), Figura 7, ilustram episódios narrados. Já a Figura 8, também retirada da Internet (Cf. Cap. 7), apresenta um ritual de passagem, sem marca cultural, o evento pós-morte do brasileiro, ícone da Fórmula I, Ayrton Senna, conforme se constata a seguir.

A Figura 5 revela hábitos brasileiros em funeral. Como se pode ver, há a exposição de coroas de flores, vela e cruz processional - esta última é usada na procissão de entrada e de saída nas missas dominicais. $\mathrm{O}$ falecido, no caso da foto, o cantor brasileiro Wando, está coberto por flores e exposto em caixão aberto, e as pessoas consternadas se vestem informalmente. Uma senhorinha, provavelmente, avó ou mãe do artista, beija-o na testa, caracterizando mais um costume brasileiro, assim como o uso de óculos escuros. Na mídia, na matéria da Internet ilustrada pela Figura foi informado que houve missa de corpo presente, o que não é comum em nosso país. 


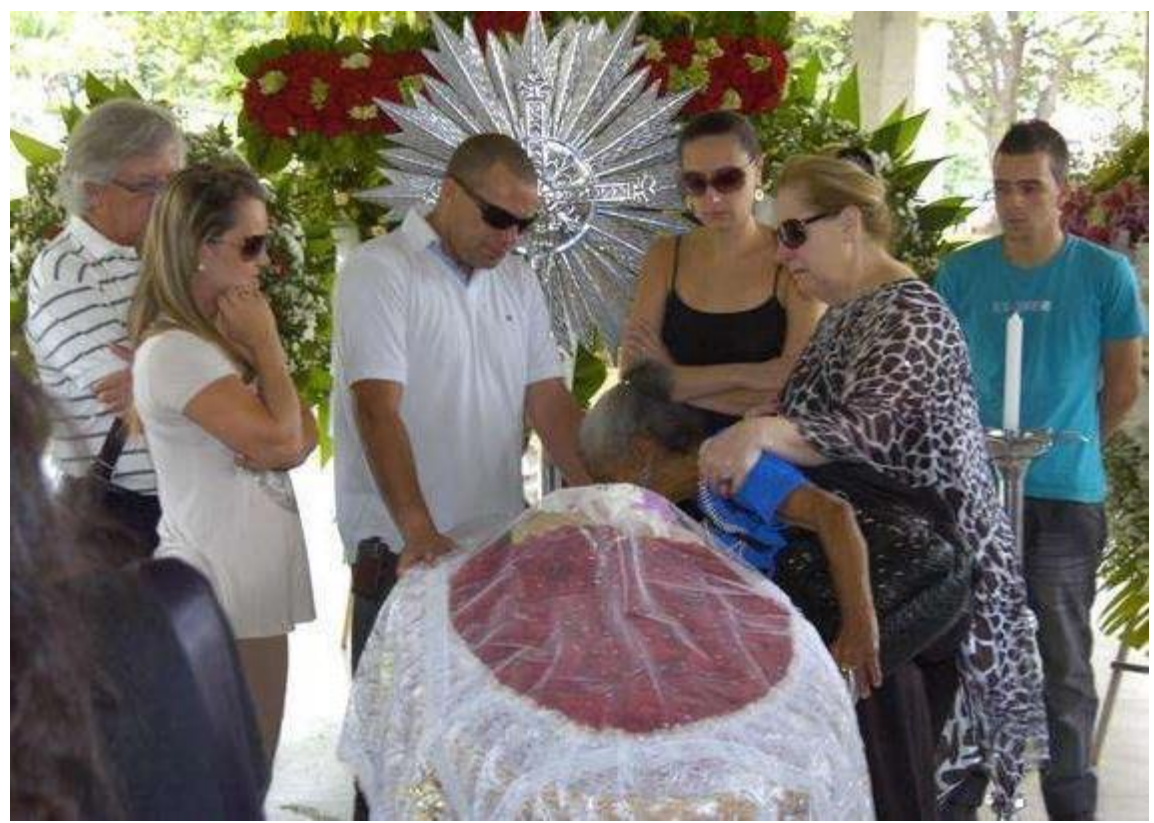

Figura 5 - Velório do cantor Wando - Cemitério Bosque da Esperança em Belo Horizonte (MG), em 09/02/2012.

Fonte: $\langle$ https://www.google.com.br/search?q=velorio+cantor+wando\&biw=1366\&bih=667\&tbm= isch $\&$ tbo $=u \&$ source $=$ univ $\& s a=X \& v e d=0 a h U K E w i X t Y P U n K 3 K A h V G k 5 A K H>$ Acesso em 30/ago/2015.

A Figura 6, imagem capturada no Canadá, retrata o caso inédito de dois irmãos, um de quatro e outro de seis anos, que foram enterrados num mesmo caixão. Nela, observamos vela, pequenos arranjos de flores, exposição de foto dos falecidos, a urna lacrada, a encomenda dos corpos pelo sacerdote: algumas das características do funeral canadense de uma família cristã.

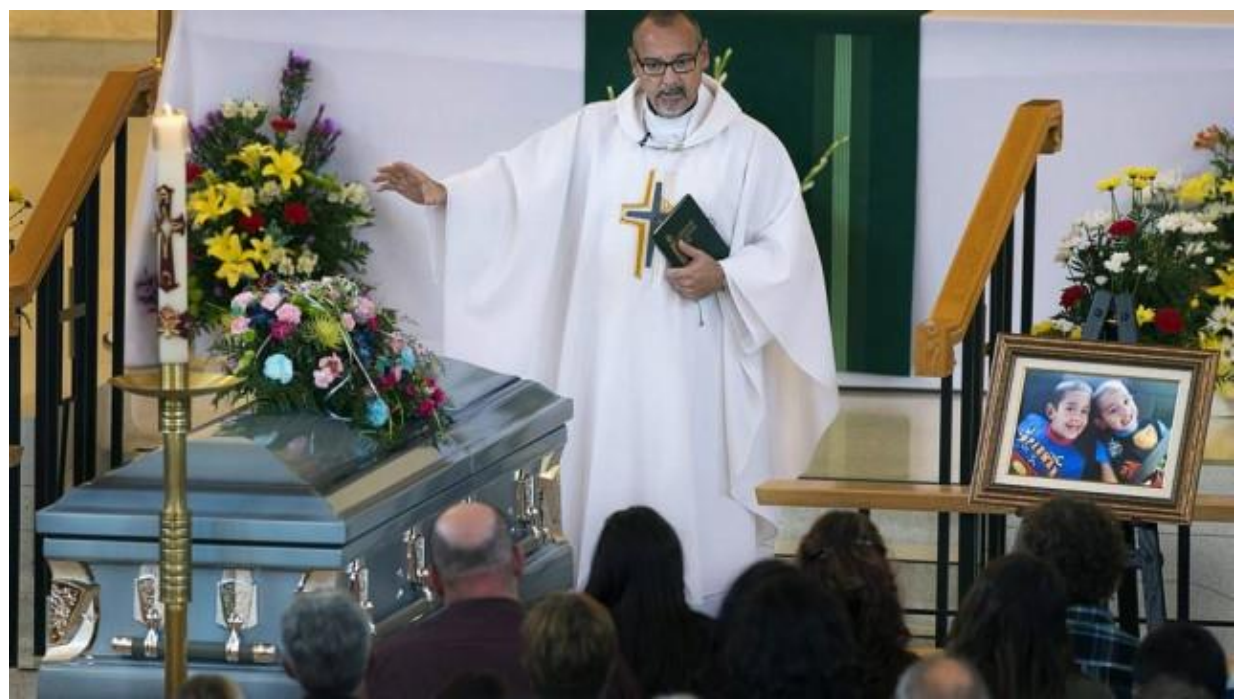

Figura 6 - Funeral em igreja católica na cidade de Campbellton, condado de New Brunswick (CA), em 11/08/2013.

Fonte:<http://www.netcina.com.br/2013/08/inseparaveis-em-vida-irmãos-mortos-por.html> Acesso: 30/ago/2015. 
Em oposição aos funerais canadense e brasileiro, na Noruega, os pastores fazem questão de que todos os familiares participem de alguma forma do evento, inclusive, crianças e adolescentes. A Figura 7 ilustra o velório de uma pessoa não religiosa, na capela de uma casa funerária, no momento em que os netos estão rendendo homenagens ao falecido pouco antes do funeral (Cf. e-mail 02). Chamamos a atenção para as coroas de flores, os arranjos no chão, o caixão lacrado que, em geral, é branco, a formalidade das roupas e a parede de vidro, permitindo que a natureza faça parte do ambiente.

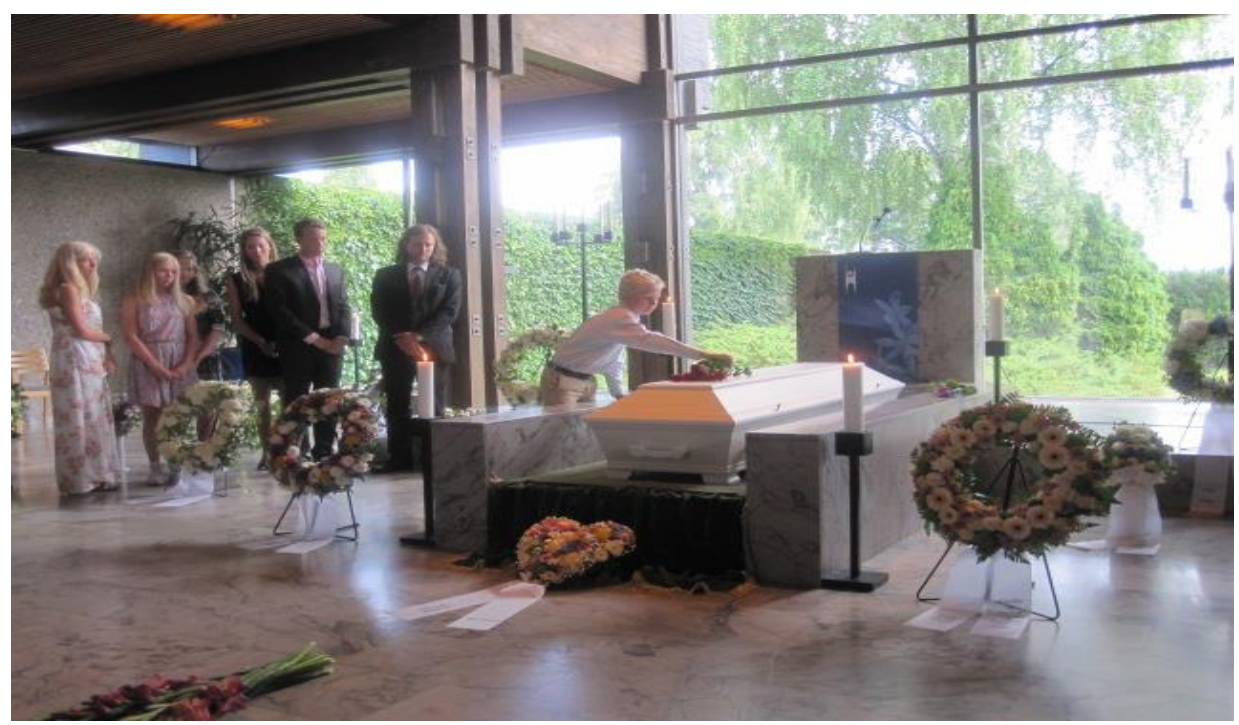

Figura 7 - Velório de pessoa não religiosa na NO (Arquivo pessoal da informante 17 (BR/NO), 2014.)

Como exceção de nossos costumes, o funeral de Ayrton Senna (Figura 8) se afasta do que em geral se presencia no Brasil, pelo fato de ele ser uma figura pública de alcance mundial. O sepultamento do piloto obedeceu a um cerimonial internacional, mais do que a ritos da religião ou da cultura dele. Também, o público presente era de múltiplas nacionalidades, de modo a universalizar a cerimônia. Observem-se a formalidade dos trajes quase uniformes dos pilotos que carregam a urna funerária; aliás, fosse uma cerimônia estritamente familiar, seriam os parentes e/ou amigos íntimos a conduzir o morto à sepultura. É provável que ali estivessem pessoas por obrigação social ou empresarial, alguns comprometidos com sua própria imagem, em função da ampla cobertura da mídia. Assim, as emoções eram diversas e contidas pelo contexto. Não houve o tradicional transbordamento do brasileiro, porque o ambiente constrangia. Todos 
os pilotos de Fórmula I do mundo vieram ao Brasil para homenageá-lo em seu enterro.

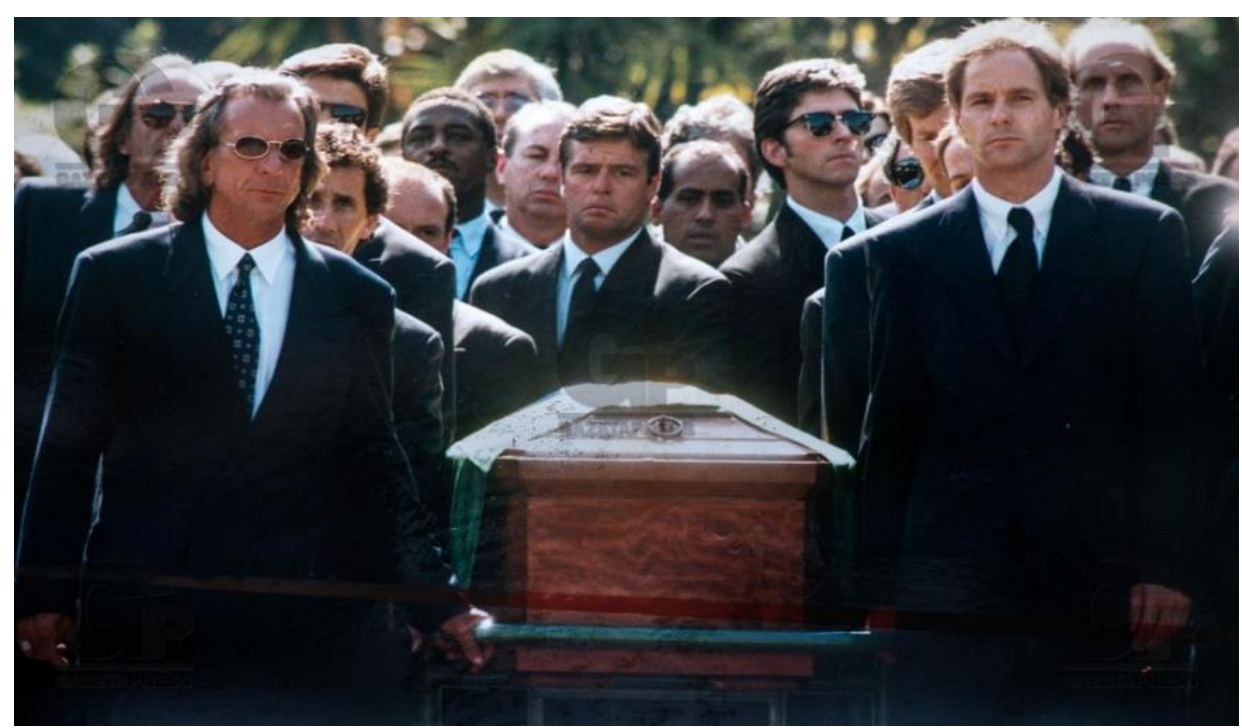

Figura 8 - Funeral do piloto de Fórmula I Ayrton Senna - São Paulo, 05/05/1994.

Fonte: $<$ https://www.google.com.br/search?q=sepultamento+de+Ayrton+Senna+imagem\&biw=13 66\&bih=673\&tbm=isch\&imgil=xaGhTZVF7 $->$ Acesso em 30/ago/2015.

A seguir, após a verificação dos dados, as análises e reinterpretações das situações ou fatos apresentados nos depoimentos colhidos dos informantes, nos diferentes contextos, e as reflexões anteriores sobre os valores culturais, os comportamentos sociais e os sentimentos pessoais que emanam das linguagens verbal e não verbal, em eventos de situação pós-morte, passamos às ponderações finais. 


\section{Conclusão}

Após a análise dos dados, podemos retomar as questões que tanto inquietaram a pesquisadora canadense: a rapidez do sepultamento; o fato de ela não ter tido as flores que havia comprado para entregá-las pessoalmente; os discursos para o morto que foram poucos e curtos; a falta do convite para o comes e bebes. Tudo isso nada mais do que configura o ritual de passagem funeral na cultura brasileira, assim sendo, não nos causa estranhamento, a nós, brasileiros. Ela não mencionou, mas deve ter ficado desorientada com o Cemitério São João Batista, com aquele amontoado de construções, muito diferente dos cemitérios na América do Norte, geralmente locais com profusão de plantas, de verde. Todos esses aprendizados vão contribuir muito para a sua competência intercultural, uma vez que, somente conhecendo os costumes do outro país e, preferentemente, também a sua língua é que, de fato, podemos nos tornar competentes no que tange os inter-relacionamentos culturais. Caso ela tivesse conhecimento das informações sobre os valores e comportamentos observadas nesta pesquisa, poderia ter entendido melhor o contexto de funeral em nossa cultura, e não teria cometido a gafe de se dirigir ao amigo do falecido como se ele fosse um gerente da casa funerária, nem teria ficado chateada por não ter sido convidada para uma comemoração da vida que nem faz parte de nossas convencionalidades.

Mas não foi apenas a Prof ${ }^{a}$ Olenka Bilash quem ganhou em termos culturais. O contato com os informantes, nas conversas e nas entrevistas que alimentamos a pretexto de coletarmos os dados, também nos permitiu aprender sobre a cultura dos outros dois povos estudados. Pelos depoimentos, passamos a entender que o modo como noruegueses e canadenses se portam num funeral e, também, a forma como julgaram os brasileiros, nas ocasiões em que presenciaram os nossos ritos, dizem bastante da forma de vida naqueles países. Por exemplo, na Noruega, uma vez tomada uma decisão, não há probabilidade de ser alterada - tal como acontece com os canadenses -, algo diametralmente oposto ao comportamento dos brasileiros, que estão sempre dispostos a reconsiderar decisões e reformular linhas de ação, se percebem que o cenário de alguma forma se modificou, ou simplesmente caso isso possa deixar seus interlocutores mais felizes. Não temos problemas em voltar atrás. Provavelmente são os ecos internos 
do colonizador em nós, pois Camões já antecipava essa nossa característica de personalidade: "Mudam-se os tempos, mudam-se as vontades".

A análise dos dados coletados na pesquisa permitiu que se confirmasse a primeira hipótese. As muitas convencionalidades diferentes entre os países de cultura ativo-linear e as de nosso país propiciam, inevitavelmente, choques interculturais. Ficou claro que se pode cometer uma ou outra gafe, ou sentir um estranhamento; por exemplo, parte dos brasileiros se surpreende com o fato de, nos outros países, levar tanto tempo para que um corpo seja sepultado. Podemos também nos sentir um pouco incomodados pelo comportamento aparentemente frio das famílias enlutadas, nós que costumamos externar com pouco pudor as nossas dores e demais emoções.

Ainda, a partir da pesquisa, podemos afirmar que, além de uma sensação interior, essas diferenças são capazes, inclusive, de provocar comportamentos linguísticos que se afastam do padrão, como ouvido num depoimento em especial em que o informante 04 (CA), tentando reproduzir seus conhecimentos pessoais sobre o contexto de situação cumprimentos em funeral, no Brasil, aproxima-se dos enlutados e se desculpa pela morte do ente ali velado, numa clara confusão de significados das expressões usadas em um país e noutro.

Quanto à celebração da vida, concluímos que este é um ritual que suscita interpretações diversas tanto no Canadá como na Noruega, onde são praxe, assim como, principalmente, aos olhos do brasileiro. Uns se admiraram com o fato de que, em pouco tempo, organiza-se uma comemoração festiva. Outros acharam tudo bonito e alegre e passaram a considerar o ritual de passagem morte, em nosso país, mais triste e doloroso.

O funeral é outra celebração cujo significado cultural, como demonstrado na Análise, pode variar - e varia mesmo - em função da orientação religiosa das famílias. Nas entrevistas, informantes que vivem ou viveram no Canadá ou na Noruega, nativos desses países ou brasileiros, citam esse evento em detalhes, como parte essencial dos ritos pós-morte, e sublinham que, no caso de famílias que professam a fé cristã, eles são bastante mais elaborados e recheados de orações e pregações de conforto à família e encomendação do defunto para o lugar onde, creem, ele será recebido e ficará em paz até que todos os demais se encontrem, um dia. Dessa ótica, o funeral guarda o dogma cristão da Vida Eterna. 
Portanto, entendemos que essa situação social relaciona-se à esfera do outro mundo, cuja porta é simbolizada pela sepultura.

No entanto, mesmo naquelas culturas, sabemos pelos relatos que há os que não professam religião alguma, mas que, nem por isso, deixam de cumprir culturalmente o rito pagão que segue o sepultamento ou cremação. Para esses, o sentido de celebrar a vida se assenta em festejar e enaltecer a vida terrena, a vida vivida neste mundo.

Por essa razão, canadenses e noruegueses, quando já sabem que o nosso sepultamento acontece, em geral, em 24 horas, chocam-se menos quanto ao fator tempo, mas ficam ainda na expectativa dos outros eventos que acontecem em seus países; para eles, seja como for, sempre há o que comemorar.

Se continuarmos a olhar para os dados levantados na intenção de verificar se eles validam ou não as hipóteses, pode-se dizer que a segunda, que diz respeito ao modo como as pessoas de cultura multiativa expressam publicamente seus sentimentos, por oposição ao modo mais contido dos indivíduos da cultura ativolinear, foi confirmada, pois canadenses e noruegueses ainda resistem ao contato físico em público, quanto mais entre interactantes que não são próximos. O beijo, mais do que os abraços, que tanto canadenses quanto noruegueses admitem acontecer entre parentes ou amigos muito íntimos, apareceu em nossas verificações como coisa de brasileiro. Quanto a expressar emoção, apesar de não ser uma regra, houve informantes admitindo que canadenses e noruegueses choram em público. Embora uma parte dos noruegueses surja nas entrevistas usando eufemismos ou expressões de abrandamento para comunicar a morte, a maior parte é bem diretiva, confirmando pertencer a uma cultura de baixo contexto.

Verificando a terceira hipótese levantada no início desta pesquisa, que diz respeito à existência de espaços sociais ambíguos no ritual de passagem funeral, apenas em nosso país ela foi ratificada pelos dados, visto que, quanto ao Canadá e à Noruega, a existência desses espaços foi detectada somente em algumas regiões desses países, quando a família enlutada e pessoas de fora estabeleceram uma relação de familiaridade e afetividade, ignorando as relações de impessoalidade e de distanciamento. Contudo, mesmo nas celebrações em estudo, prevaleceu o não englobamento entre os espaços da casa e da rua. Corroborando, novamente, a 
existência de uma cultura de baixo contexto, em geral, as pessoas apenas cumpriram uma convenção social, com comportamentos frios e emoção controlada, enquanto no Brasil, sempre, podemos interpretar esses espaços como ambíguos, pois amigos e pessoas conhecidas comparecem em apoio à família enlutada, compartilhando sentimentos de amor e gestos afetivos; sendo assim, a casa se sobrepõe à rua. Por outro lado, identificamos, nesses países de cultura ativo-linear, um espaço ambíguo referente às relações interpessoais, caracterizado pela ausência de distanciamento entre família enlutada e celebrante religioso, inclusive, paradoxalmente, quando não se conheciam. No Canadá, o pastor, na intenção de marcar presença da Igreja na comunidade, agenda uma reunião com a família para celebrar uma cerimônia bem personalizada, faz questão de participar do evento festivo e estabelece um vínculo de amizade, posteriormente, fazendo visitas à família. Na Noruega, a pastora prefere fazer a reunião na casa da família enlutada para ficar mais próxima. Conversam sobre a vida do falecido, tomam café, veem fotos, estabelecendo, assim, um relacionamento amistoso. Depois, trocam e-mails para verificar se os familiares estão satisfeito com o discurso que a religiosa fará. Caso não estejam, ela faz as devidas alterações para que tudo fique a contento. Considerando esses dois episódios e as variantes citadas, podemos dizer que a terceira hipótese só foi parcialmente comprovada.

As variações internas ocorrem porque, em todos os países, há diferenças culturais, ainda mais nos de grande extensão territorial que abrigam, em sua história, muitos imigrantes. Não se pode esquecer, especialmente, o Canadá, onde o governo faz questão de preservar os valores das culturas que acolhe. Apesar de haver, também, imigrantes de diversas nacionalidades no Brasil e na Noruega, nesses países, não há um programa de conservação da cultura dos povos que imigram como existe no país da América do Norte.

Tendo em vista o fator multiculturalidade, e estabelecendo um paralelo com a língua, que evolui diacronicamente, talvez possamos falar de uma lenta e gradativa mudança cultural a partir de recíprocas influências que aproximem mais os países de culturas ativo-linear, multiativa e reativa, contribuindo de certa maneira para o interculturalismo entre as nações. De todo modo, entendemos, com clareza, que o diagrama que classifica as identidades nacionais é escalar, o que foi constatado com as variações regionais de valores e comportamentos apresentadas 
pelos dados. Por estar no eixo ativo-linear/multiativo, a Noruega, embora distante do vértice ocupado pela cultura multiativa, pode assimilar características desta. Quanto ao Canadá, este está no ponto central de seu eixo, exatamente abaixo do vértice em que se encontra o Brasil, logo, aquele pode sofrer influências deste. Isso não significa que o Canadá e a Noruega sejam de cultura híbrida ativolinear/multiativa, mas temos que admitir que, embora numa pequena proporção, no contexto de situação funeral, alguns dados apontam para o fato de que os três países praticam uma postura comum. Outro fator que aproxima Brasil e Canadá é que ambos recebem influência da cultura reativa. Logo, as diferenças de comportamento encontradas na cultura ativo-linear, aqui representada por canadenses e noruegueses, já eram previstas por Lewis (Cf. 2.1.3.2) nas categorias em observação, justificando-se assim alguns dados que revelaram, de certa forma, convergência de comportamentos entre brasileiros, canadenses e noruegueses.

Para além do entendimento do que se ficou sabendo sobre as culturas de Brasil, Canadá e Noruega nos ritos funerais, esta pesquisa enseja reflexões mais profundas sobre o que se lê nesses contextos de situação acerca do modo de vida das pessoas nesses três países e que pode passar despercebido. Uma curiosidade observada a partir dos relatos e que também revela as condições de vida nas três nações diz respeito à causa da morte. Na Noruega, país onde a qualidade de vida é sabidamente superior, a maioria dos relatos fala em funerais de idosos (a mãe, a avó, a tia); já quando os estrangeiros falam de velórios que assistiram no Brasil, falam em acidentes; um fala de crime, da morte de pessoas jovens que, por isso mesmo, causou mais comoção. Um leitor atento vai perceber que não estamos diante de mera coincidência, mas sim, da constatação de que o modo como se vive aqui, por exemplo, o que incita a violência urbana, é responsável por muitas mortes precoces na nossa sociedade.

Ainda seguindo essa linha de raciocínio, outro aspecto abordado pelos entrevistados que a corrobora foi que, nas cidades grandes, não se fazem mais velórios durante a noite toda, o velório, no sentido primeiro da palavra, não por razões culturais, mas por questão de contingência imposta pelo modo de vida das pessoas, que fica, como exposto, determinado pela violência urbana.

Como se observa, algumas questões subjacentes ao tema levam a raciocínios mais amplos e profundos sobre o modo como os comportamentos das 
pessoas funcionam como instrumentos culturais e sociais de comunicação e interação, revelando suas nações aos outros nos pequenos gestos e na seleção vocabular nesta ou naquela situação.

Fica a lição: o contexto de situação pode ser o mesmo, mas, quando se muda o contexto de cultura, há que se mudar as lentes com as quais se enfoca o fato social, sob pena de se perder o sentido inerente ao fato em si. Tamanho estranhamento desvia o foco dos sentimentos genuínos e provoca outros que podem desencadear julgamentos precipitados e, na maior parte das vezes, injusto.

Esses pontos culturais que ora se aproximam, ora se afastam devem ser divulgados para que possa haver uma competência intercultural globalizada entre interactantes do Brasil, Canadá e Noruega, para o caso de se deparem com um contexto de interação em funerais no país do outro.

Os dados colhidos são as chaves interpretativas desse fato social nesta investigação, mas podem ser usados para que novas pesquisas sejam feitas nos âmbitos cultural e antropológico. Fica aqui o desejo de que este trabalho desperte em outros pesquisadores a vontade de investigar um pouco mais sobre países de culturas diferentes, em outros temas, mas numa perspectiva linguísticoantroplológica que é a entrada para uma competência intercultural. Acreditamos que pesquisas como esta - ou desta derivadas - possam vir a preencher lacunas no acervo do conhecimento acadêmico e colaborar para a competência intercultural numa interação face a face entre cidadãos das diversas culturas mundo afora. 


\section{Referências Bibliográficas}

AFS Intercultural Programs, Inc. [on-line]. Contribuições de Edward T. Hall. afs.org.br, 2011. Disponível em <http://www.afs.org.br/uploads/files/22_1__Contribuicoes_de_Edward_T._Hall...para_amigos_do_AFS.pdf $>$

Acesso em 20/abr/2015.

ALVES, R. Sobre a morte e o morrer. Jornal Folha de São Paulo, São Paulo, 12 out. 2003. Caderno Sinapse, p. 3.

ASSOCIAÇÃO BRASILEIRA DE NORMAS TÉCNICAS. NBR 14724: informação e documentação - trabalhos acadêmicos apresentação. Rio de Janeiro, 2001.

AZEREDO, J. C. de. Gramática Houaiss da Língua Portuguesa. 2. ed. São Paulo: Publifolha, 2008.

AZEVEDO, F. F. dos S. Dicionário analógico da língua portuguesa: ideias afins/thesaurus. 2. ed. atualizada e revista. Rio de Janeiro: Lexikon, 2010.

BAKHTIN, M. Estética da criação verbal. 4. ed. São Paulo: Martins Fontes, 2003.

BAUER, M. W.; GASKELL, G. Pesquisa qualitativa com texto, imagem e som: Um manual prático. 8 ed. Petrópolis: Vozes, 2010. [Cap.5. Entrevista episódica. p.114-136]

BECHARA, E. Moderna Gramática Portuguesa. 37 ed. rev. Rio de Janeiro: Nova Fronteira, 2009.

BENEDICT, R. O crisântemo e a espada. São Paulo: Perspectiva, 1972.

BENNETT, M. J. Basic Concepts of Intercultural Communication: selected readings. Yarmouth: Intercultural Press, 1998.

CAMÕES, L. V. de. Os Lusíadas. Porto: Porto, 2006.

CASTILHO, A. T.de. Gramática do Português Brasileiro.1. ed. 3 reimpressão. São Paulo: Contexto, 2014.

DAMATTA, R. O que é o Brasil?. Rio de Janeiro: Rocco, 2004.

. A Casa \& A Rua: espaço, cidadania, mulher e morte no Brasil. 5. ed. Rio de Janeiro: Rocco, 1997.

Para uma antropologia da tradição brasileira (ou: a virtude está no meio). In: Conta de mentiroso: sete ensaios de antropologia brasileira. Rio de Janeiro: Rocco, 1993. p. 125-149.

Relativizando: uma introdução à Antropologia Social. Rio de Janeiro: Rocco, 1987.

. O que fez o brasil Brasil?. Rio de Janeiro: Rocco, 1984. 
FLICK, U. Desenho da pesquisa qualitativa. Porto Alegre: Bookman; Artmed, 2009.

FULGÊNCIO, L. Expressões fixas e idiomatismos no português do Brasil. 2008. Belo Horizonte: tese de doutorado, PUC-Minas, 2008.

HALL, E. T. The Silent Language. Garden City. New York: Anchor Books, 1990. Beyond Culture. Garden City. New York: Anchor Books, 1989.

HOFSTEDE, Geert. Cultures and Consequences - Comparing Values, Behaviors, Institutions, and Organizations across Nations. 2. ed. Tousand Oaks/London/New Delhi: Sage Publications, 2001.

HOLANDA, F. B. Novo dicionário da língua portuguesa. 2 ed., 35 impressão. Rio de Janeiro: Nova Fronteira, 1997.

HOLANDA, S. B. Raíses do Brasil. São Paulo: Companhia das Letras, 1995.

HOLLIDAY, A. R. Intercultural communication and ideology. London: Sage, 2011.

HOUAISS, A. et al. Dicionário Houaiss da língua portuguesa. 1 ed. Rio de Janeiro: Objetiva, 2012.

Jornal O Globo, Rio de Janeiro, 18 jul. 2015. Seção Obituário. Primeiro Caderno, p. 16.

Jornal O Globo, Rio de Janeiro, 16 maio 2015. Seção Obituário. Primeiro Caderno, p. 16.

LANTOLF, J. P. Sociocultural theory and second language learning. Oxford: Oxford University Press, 2000.

LARAIA, R. de B. Cultura: um conceito antropológico. 16 ed. Rio de Janeiro: Zahar, 2003.

LEWIS, R. D. When Cultures Collide: leading across cultures. Nicholas Brealey International, 2006.

MARCONI, M. de A.; LAKATOS, E M. Técnicas de pesquisa: planejamento e execução de pesquisas, amostragens e técnicas de pesquisas, elaboração, análise e interpretação de dados. 5 ed. São Paulo: Atlas, 2002.

MEYER, R. M. de B. Da polidez em inglês à cordialidade em português: diferenças interacionais. In: Congresso SIPLE, 4, 2001, Rio de Janeiro. Anais. Rio de Janeiro: PUC-Rio, 2001.

Língua portuguesa do Brasil e cultura brasileira: cara e coroa. In: Congresso SIPLE, 2, 2001, Rio de Janeiro. Anais. Rio de Janeiro: PUC-Rio, 1999. 
. Para o bem ou para o mal: a construção de identidade pelo falante de PL2E a partir de estereótipos de brasilidade - uma questão intercultural. In: MEYER, R. M. de B.; ALBUQUERQUE, A. (Orgs). Português para Estrangeiros: Questões Interculturais. Rio de Janeiro: Ed. PUC-Rio,2013. p. 13-34.

MOESCH, M. M. A produção do saber turístico. São Paulo: Contexto, 2000.

MURDOCK, G. P. The Science of Culture. American Anthropologist. ns, 34: 200-215 (1932).

PARANHOS, M. L.; DAMAZIO, V.; MEYER, R.M. de B. Welcome to PUCRio!: um estudo sobre alunos internacionais e interação cultural sob a perspectiva do Design. 2011. Dissertação (Mestrado em Artes e Design) - Pontifícia Universidade Católica do Rio de Janeiro, Rio de Janeiro, 2011. Disponível em: $<$ http://www2.dbd.puc-

rio.br/pergamum/biblioteca/php/mostrateses.php?open=1\&arqtese=0912504_11_I ndice.html> Acesso em: 04/ abr/ 2014.

PERINI, M. A. Gramática do Português Brasileiro. São Paulo: Parábola Ed, 2010.

Ática, 2003. . Gramática descritiva do português. 4 ed., 6 impressão. São Paulo: . Sofrendo a Gramática. São Paulo: Ática, 1999.

PETERSON, B. Cultural Intelligence. Yarmouth: Intercultural Press, 2004.

PORTO, C. B.; Meyer, R. M. de B. "Pessoal e oficial ao mesmo tempo" / espaços limítrofes no ambiente de trabalho na sociedade brasileira e o ensino de portugês como segunda língua para estrangeiros. 2006. Dissertação (Mestrado em Letras)Pontifícia Universidade Católica do Rio de Janeiro, Rio de Janeiro, 2006 Disponível em: <http://www2.dbd.pucrio.br/pergamum/biblioteca/php/mostrateses.php?open=1\&arqtese=0410509_06_I ndice.html> Acesso em: 02/maio/2014.

ROSA, J. G. Grande Sertão: Veredas. Rio de Janeiro: Nova Aguilar, 1994.

SAUSSURE, F. de. Curso de Linguística Geral. São Paulo: Cultrix, 1995. Pág. 79-84.

SINGER, M. Perception and Identity in Intercultural Communication. Yarmouth, Maine: Intercultural Press, 1998.

TAGNIN, S. E. O. O Jeito que a gente diz: combinações consagradas em inglês e português. Barueri, SP: Disal, 2013.

. Expressões idiomáticas e convencionais. São Paulo: Ática, 1989. 


\section{Sites Web Apresentados}

<http://www.ibge.gov.br/apps/populacao/projecao/> Acesso em 02/abr/2015.

<http://countrymeters.info/pt/Canada> Acesso em 06/abr/2015.

<http://populationpyramid.net/pt/noruega/2015/> Acesso em 02/abr/2015.

<http://www2.unesp.br/revista/?p=6347> Acesso em 18/maio/2015.

$<$ https://pt.wikipedia.org/wiki/Cemit\%C3\%A9rio_da_Recoleta> Acesso em 03/abr/2015.

$<$ http://guiadoturista.uol.com.br/roteiros/historico-e-cultural/turismo-cemiterialcemiterios-turistas-mundo-brasil/> Acesso em 03/abr/2015.

<http://www.afs.org.br/uploads/files/22_1_-

_Contribuicoes_de_Edward_T._Hall...para_amigos_do_AFS.pdf >

Acesso em 20/abr/2015.

<http://buscatextual.cnpq.br/buscatextual/visualizacv.do?id=K4728529Z1>

Acesso em 02/maio/2015.

<http://globotv.globo.com/rede-globo/encontro-com-fatima-bernardes/v/encontrocom-fatima-bernardes-programa-de-quinta-feira-25062015-na-integra/4277690/> Acesso em 25/jun/2015.

<https://www.google.com.br/search?q=velorio+cantor+wando\&biw=1366\&bih=6 $67 \&$ tbm $=$ isch $\&$ tbo $=u \&$ source $=$ univ $\&$ sa $=X \& v e d=0 a h U K E w i X t Y P U n K 3 K A h V G$ k5AKH> Acesso em 30/ago/2015.

<http://www.netcina.com.br/2013/08/inseparaveis-em-vida-irmãos-mortospor.html> Acesso em 30/ago/2015.

$<$ https://www.google.com.br/search?q=sepultamento+de+Ayrton+Senna+imagem \&biw $=1366 \&$ bih=673\&tbm=isch\&imgil=xaGhTZVF7-> Acesso em 30/ago/2015. 


\section{Anexos}

\subsection{Anexos A}

\section{Informante $01 \mathrm{CA}$}

No Canadá, fui a funerais de membros da família, de pai, ou filho de amigos, ou de colegas. No Brasil, foi a morte do pai da minha família hospedeira. Um homem com quem eu tinha tido mais de dois meses de conversas, quase diárias, em inglês, francês e português. No Canadá, já assisti a funerais em Winnipeg, Edmonton, Vancouver e em cidades pequenas.

$\mathrm{O}$ que mais me chocou, no funeral, no Brasil, foi que ele se realizou dentro de 24-30 horas, um tempo muito curto. Não houve comida nem recepção. Os discursos foram poucos, muito curtos e não muito pessoais. Depois do enterro, sem saber o que iria acontecer, o que fazer, minha filha e eu esperamos para ver se alguém ia falar com a gente, dizer qual seria o próximo passo. Senti a incerteza sobre o processo, medo de me comportar de forma inadequada e interromper esse tempo sagrado para a família. Não recebendo nenhuma orientação, fomos a pé para casa. Mais tarde, fomos informadas de que teria sido dada uma carona para casa, mas éramos pensionistas, e não membros da família, portanto não quisemos nos intrometer nesse espaço pessoal.

No Canadá, cumprimentamos a família enlutada de acordo com a proximidade do relacionamento. Aperto de mãos para pessoas estranhas e abraço para amigos próximos e familiares. Esses gestos são acompanhados pelas expressões: "Ele está em um lugar melhor agora.", "Felizmente, o sofrimento dele acabou.", "Meus sinceros pêsames.", "Minhas sinceras condolências.", "Por favor, fale-me se há alguma coisa que eu possa fazer.", "Foi um serviço belo e tocante.". Essas expressões, às vezes, são seguidas de comentários sobre a vida boa e de liderança do falecido, suas contribuições, sendo uma boa pessoa para a família. Se a pessoa estava gravemente doente, observamos o fim do sofrimento. $\mathrm{O}$ choro mostra a profundidade de uma conexão e empatia.

Nos funerais, tenho vontade de estender meu apoio à família, ajudando-a a esquecer o falecido. Lembro-me da brevidade da vida e de como é importante viver todos os dias bem, sem tomar nada como garantido. Mostro empatia para a família e tiro lições de vida do modo como ela reage/responde. Para nós, canadenses, após o enterro, se a morte foi na família direta, temos que suportar o luto, mas, para a maioria dos participantes, há um sentimento de encerramento, uma sensação de memórias positivas. Se eu já tivesse tido um momento desagradável com a pessoa falecida, ela desaparece, e eu sinto liberdade e alívio.

Após o enterro, dependendo da formação da pessoa, normalmente, há uma refeição ou lanche e a oportunidade para as pessoas, informalmente, compartilharem histórias do falecido. $\mathrm{O}$ choro dos dias anteriores se transforma em riso e boas lembranças.

A comida oferecida, após o enterro, por vezes, tem a ver com o gosto do falecido, mas nem sempre. É comum que a pessoa deixe, por escrito, tudo que vai querer em seu funeral. Às vezes, deixam até pago. Talvez, a comida esteja relacionada com a generosidade e hospitalidade da pessoa e sua formação cultural. Por exemplo, eslavos vão ter muita comida enquanto britânicos têm muito pouca, em geral. Francófonos terão fartura. O mesmo acontecerá com os alemães. Escoceses, geralmente, não tanto. 


\section{Informante 02 CA}

Tenho 43 anos, sou professora do ensino elementar. Visitei o Brasil e participei de um funeral. A coisa que me chocou foi o tempo super-rápido entre a morte da pessoa e o enterramento. Aqui, no Canadá, essa parte é muito diferente. O tempo foi muito curto entre aprender que a pessoa morreu e o enterramento. Os sentimentos são humanos. As pessoas tão bem tristes choraram. O sentimento estava bem evidente. Aqui, no Canadá, temos uma semana ou mais para pensar o que passou, quem morreu. Então, no funerário, a gente parece que não sofre, a gente tem mais tempo, tá mais calmo. No funeral, no Brasil, a gente tava chorando, chorando. Acho que é a questão do tempo. Parece que o sofrimento é bem evidente porque a morte foi ontem. No Brasil, a maioria das pessoas são católicas, mas, aqui, tem várias religiões. Eu sou menonita. É parecido com protestante.

Quando eu tive dez anos, a minha tia morreu. Depois de uma semana, foi o funeral na igreja em Ontário. Foi como um culto que durou 3 horas. Várias pessoas falaram como se fosse um culto de domingo, uma missa, mas foi de 3 horas. Depois, o enterro foi ali, ao lado da igreja. Fomos caminhando, e o pastor fez uma oração. Aqui, no Canadá, a gente não fica vendo enterrar o caixão, só colocar o caixão dentro do túmulo. E, daí, fomos à casa de meu tio, e ficamos esperando toda a gente chegar para comer uma comidinha muito grande que foi preparada para todas as mulheres da igreja. Foi uma cerimônia muito particular da comunidade unida. Passamos umas horas, falando da vida da tia.

Vários funerários de meu pai e, também, de outras religiões, normalmente, é no final de semana. Eu acho que é pra a chance de toda a família chegar, porque o Canadá é muito grande. E muitas famílias não vivem muito perto. Outra coisa, aqui, no Canadá, aerolinhas, como Air Canadá , quando você tem um parente que morre, você pode entregar uma letra que diz que o parente morreu e você tem um desconto de $50 \%$.no seu boleto de voo. Depois de uma semana ou mais, você tem o velório. Uma noite ou, às vezes, duas noites. Você põe uma notícia no jornal que diz que, de 7:00 às 9:00 horas, a quinta-feira e a sexta-feira, vamos ter velório do corpo. A maioria do tempo você pode ver o corpo, mas depende de a pessoa morreu com um acidente, o caixo tá fechado. Mas, normalmente, tá aberto, e todas as pessoas podem ir só pra falar com a família, dar seus sentimentos, para comer, uma, duas horas. Tem comida, café, assim, algo pra comer. É um business. Quando a pessoa morre, normalmente, aqui, no Canadá, é um médico polícial que tem que dar um exame que diz de que a pessoa morreu. Isso pode levar de 1 a 3 dias. Depois, a casa funerária faz algum químico adentro do corpo pra que dure uma semana, duas semana. Depois, se a família está religiosa, pode ter uma cerimônia na igreja de pessoa. Aqui, no Canadá, no passado, se você tava católico, mas se algo passou com você, o padre pode resgatar você de alguma coisa, não pode fazer a cerimônia na igreja católica. Na igreja protestante, isso nunca passa. O pastor não vai dizer: "não, você não pode fazer o serviço aqui”. Normalmente, essa cerimônia acontece no sábado, e tem um serviço como uma missa que dura 1 hora. O padre fala, a família pode falar. Muita gente são convidado, mas, normalmente, só a família e amigos próximos vão. O túmulo não é tão pertinho da igreja. Os cemitérios são compartilhados entre as igrejas e são bem grandão. Cada igreja não tem seu cemitério. Cada pessoa entra em seu carro. Tem um carro negro, especial, mais largo, que tem o corpo, e, primeiro, a família mais próxima segue esse carro. É uma tradição aqui, no Canadá, ter esse tipo de carro. Se chama procissão funerária e todos os carros param.

Tem uma parte no hospital em que eles guardam os corpos que não sabem de quem são. Senão, o corpo, depois de ser examinado pelo médico policial, vai, imediatamente, no salão funerário, casas funerárias. Eles faz toda essa parte de preparar, maquiagem no rosto para preparar o corpo. A maioria da gente tem um seguro, porque pode custar mais ou menos como uns dez mil dólares. A maioria das gentes estão pondo adentro da terra, mas, também, agora tem mais pessoas que gostam de fazer cremação, é mais popular, porque falta de lugar, às vezes, no cemitério. A cremação é muito mais barata. Acho que é menos que mil dólares. Pagar para o caixão, o carro, tem que comprar um lote no cemitério. Isso custa dinheiro, depende do lote, tem que pagar para o 
carro, tem que pagar para muitas coisas. Então, pode ser bem caro. Na minha religião não é problema, mas tem religião aqui que não permite a cremação. Então, depende da religião, da família, se vai fazer, ou não. Normalmente, é uma semana ou mais para o corpo ser enterrado. No período de luto, não é a família que faz a comidinha, normalmente, é a comunidade da igreja, amigos, mas não é família. Muitas vezes, depende da igreja. A comunidade vai levar cada dia, uma comidinha para a família. A comidinha que comemos depois do enterramento, isso não é a família que faz. Nunca. É a comunidade, ou amigos. Se não tem, vai pagar pra não sei quem. Em todos que eu fui, foi a comunidade que fez a comidinha. Em todos que eu fui, havia uma recepção. Depende da família. É uma recepção que combina mais tipo buffet que a gente está, andando adentro da casa, estão falando, estão comemorando a pessoa que morreu. É mais, assim, tipo sanduiches, frutas, não sei o quê. Coisas que a pessoa pode comer com sua mão.

Tem flores, normalmente, sobre o caixão, mas, ultimamente, estão pondo num programa no jornal, sempre, a maioria de gente colocam: "Por favor, não tragam flores, porque as flores morrem. Façam uma doação pra tal entidade em nome da pessoa que morreu. Levar flores, as pessoas acham que é jogar dinheiro fora.

Nos cumprimentos, se você é próximo, você vai abraçar e dizer condolências. Senão, é aperto de mãos. As expressões "a pessoa passou pra outro lado" " minhas condolências por sua perda". Sempre, na religião protestante, vamos dizer que vamos ver a pessoa depois, no céu, que ela está em paz. Agora, tem pessoa que estão celebrando sua vida antes de morrer, que são gente que não querem ter funerário. Eles fazem quando têm câncer e sabem que vão morrer. Faz o funeral, mas a pessoa está viva, está ali na igreja. Não sei o que vai acontecer quando ela morrer. Acho que não vão convidar a gente, só a família. Não é muito comum. A celebração, em geral, é no dia do enterramento. O dia do enterro é o mesmo dia de todas essa celebração, missa, enterramento, recepção, da comida com a família. O velório que é dias antes. O tempo no Brasil é tão rápido. O que fui não tinha comida, só café preto, era pequeno. Somente passar, dar os cumprimentos e ficar lá fora. Isso foi bem diferente para mim. Aqui não se fala a palavra morreu, nós falamos perda.

\section{Informante $03 \mathrm{CA}$}

Tenho 50 anos, sou garçom num restaurante aqui, em Halifax. Aqui, no Canadá, as pessoas contratam uma casa de funeral. Eles cobram cerca de cinco mil reais. Eles cuidam de tudo. Você escolhe o caixão e o que mais quiser. Às vezes, as pessoas compram o próprio funeral, ou um seguro. Normalmente, o caixão fica aberto, mas, se o rosto estiver desfigurado, é fechado. Na cidade tem muitas casas de funeral diferentes. Quando alguém morre, você contrata um serviço e não se preocupa com nada. O diretor da casa funerária cuida de tudo. Três, quatro dias depois, eles fazem um wake para as pessoas visitarem o corpo. O caixão fica aberto e todos podem ir ver o corpo que está embalsamado. Tem muitas flores no funeral; as pessoas levam. Mas se morrer de câncer, ataque cardíaco, os familiares pedem para, no lugar de levarem flores, fazerem uma doação em dinheiro para alguma instituição que cuide da doença que causou a morte.

Costuma ter um livro de assinatura. Se a pessoa é religiosa, o funeral é numa igreja. Aqui, em Halifax, há duas religiões que predominam, a católica e a protestante. Quando alguém morre, as pessoas amigas levam alimentos para a família do falecido. Tem uma coisa aqui que quem é de fora não entende. Depois do funeral, há um hábito de festejar a vida do morto com muita comida, muita bebida. Nós somos tristes, mas nós queremos celebrar a vida da pessoa que morreu, com os familiares. Essa celebração pode ser até na casa da pessoa, onde ela morava. Tem exposição de fotos, as pessoas falam da vida do falecido, das coisas boas. Minha esposa brasileira acha isso uma coisa estranha, você está triste e feliz ao mesmo tempo. A pessoa morreu, mas você está pensando 
só sobre as coisas boas, às vezes, engraçadas. Um pouco de ambos. O funeral pode ser em qualquer dia da semana.

As pessoas se cumprimentam com abraços e aperto de mãos. Elas dizem: "Sinto muito pela sua perda.". Quando eu era uma criança, fui a muitos funerais. Agora não mais, felizmente. As pessoas choram porque elas têm emoções, independente de onde elas estão. As lágrimas correm, mas as pessoas só se descontrolam dentro de casa. Nós somos mais controlados. Para ir ao velório, as pessoas se arrumam bem. Os homens vão de terno, e as mulheres vão de vestido. Em geral, vestem preto, mas não necessário. A maioria usa preto. Normalmente, o funeral é feito numa igreja. Tem duas coisas. Primeiro uma wake, três, quatro dias depois da morte, num espaço na casa funerária. As famílias e amigos se encontram, falam sobre ele. O wake é numa sala confortável, temperatura ambiente, com flores, sofás, quadros nas paredes.

Todos os corpos são embalsamados, por conta disso que as pessoas fazem um seguro, pois esse tratamento não é barato. Se você tem uma religião, tem um funeral. Se não tem, em geral, só tem um wake. Tudo mundo tem um wake. O funeral é dois, três dias depois do wake. Os cemitérios são como se fossem um campo grande, gramado. Tem um que é muito visitado por turistas porque, nele, estão enterradas muitas vítimas do Titanic.

Uma maneira de se suavizar o aviso de morte é "passed away", "ele passou". Uma expressão grosseira é "chutar o balde", usado mais para uma pessoa distante, como um ator.

Normalmente, toda pessoa que morre tem um anúncio no jornal.

\section{Informante $04 \mathrm{CA}$}

Fiquei um tempo em Brasília, depois mudei pra Anápolis, Goiás, e depois de volta pra Brasília, pro resto do estagia. Na minha vida, só fui a dois funerais: um no Brasil e o da minha mãe. Na verdade, foi bem mais formal no Brasil, foi bem mais organizado, foi na igreja católica. Então, acho que tem mais formalidade do que aqui, no Canadá. O funeral da minha mãe, como nossa família não é religioso, nós fomos só prum velório, não era na igreja, numa empresa que cuida desse tipo de coisa.

No Brasil, foi o primeiro que eu fui na minha vida. Foi há seis anos atrás. Eu tava bem choquiado porque eu era muito próximo o meu sogro, foi difícil. Eu tava junto com a família, eu vi o dor de todo mundo, eu senti junto com eles o desconforto do morto. Foi bem rapidinho. Depois que ele faleceu, ele não ficou na casa muito tempo, veio logo dois caras, que eu não conheço quem eram, na realidade, e levou ele já já pro velório. O velório tava bem naquela noite. Antes do funerário, a gente passou por aquela tristeza. Eu estava presente quando ele faleceu, e minha esposa não estava. Então, eu senti bem responsável, como eu estava representando a família, minha esposa, por exemplo, lá. Ele tava doente faz tempo, ela foi, voltou. Ele tava pra falecer quando ela estava lá, só que ele não faleceu. Ela tinha que voltar. Depois, eu resolvi ir pra falar tchau pra ele e também pra participar no funerário. Só que ele não faleceu enquanto eu tava viajando, mas ele faleceu dois dias depois que eu cheguei. Ele já tava de volta em casa, ele não quis morrer no hospital. Então, foi trazido de volta pra casa nos últimos dias, e eu estava presente quando ele faleceu. Fiquei a noite toda no funerário que foi na casa funerária, encostada no cemitério. Ele foi enterrado no dia seguinte, à tarde. As pessoas chegavam e falavam com a minha sogra, a família e depois indo embora. Ele era muito conhecido na cidade, e foi muita gente mais velhos. Vieram pra pagar os últimos respeitos. Minha sogra era bem composta, ela não chorou muito porque já tinha chorado muito. Assim, ela já tava, estava acostumada com ele bem doente há muito tempo, ela sabia que ele ia falecer qualquer momento. Ela chorou, mas não excessivamente. Ela veio bem arrumada, bem composta, como se fosse numa trança (sic), pra mim também era tipo meia trança (sic), eu tava sabendo o que tava acontecendo, mas o tempo passou lento, passou rápido, meio que um estado de choque, eu acho. Eu nunca tive choque, mas eu imaginei que esse 
foi o mais próximo que eu senti. Eu tenho muito amor pra minha família, a família da minha esposa, que eu chamo de minha também, meu sogro também. Eu tava sem saber, porque, como eu sabia que a família é católica, eu imaginei que ia ser estranho pra mim. Eu quis agir de um jeito certo. Como eu não tinha ido pra outro funerário na minha vida, eu estava assim seguindo, fazendo rolar com o assunto, entendeu?

Pra mim foi explicado aqui que, nos países mais quentes, o enterro é no dia seguinte porque o corpo derrete mais rápido, é mais um caso de necessidade do que qualquer outra coisa. Por isso, não estranhei o tempo de 24 horas. O que achei incomum é a Missa de Sétimo Dia. Sempre ouvi falar dessa missa no Brasil, mas não no Canadá. No funerário, eu não imaginei que ia ter gente aparecendo a noite inteira. Parece que o povo tava querendo vir, pelo menos, aparecer. Queriam achegar (sic) o mais rápido possível, pelo menos, assim, parece que foi uma corrida pra todo mundo, quem chega primeiro, quem veio de qualquer jeito, não importa a hora, vem de madrugada, vem quatro horas da manhã. Tinha gente que chegou pra passear. Como teve gente que veio do estado inteiro, acho que deram a desculpa que "Vim assim que ouvi.", "Vim assim que puder.". Esse tipo de coisa. Todo mundo conhecia ele e quis descobrir qual que era o relacionamento entre eu e a família.

A cidade é agrícola, mas, mesmo assim, toda mulher que apareceu era bem vestida. Vestido de formal. Não me lembro de ter visto cores alegres. Era mais preto. Achei estranho as muitas rodas, anel com faixas. Essa é uma coisa que não existe aqui. Nas faixas, vinha escrito: "Sentimentos da família blábláblá.", "Com muito amor, da família Y.”, "Pêsames da família X.". Tipo isso. No dia seguinte, chegam muitas dessas flores. Foi entregado pela empresa, deixado lá, e, também, depois que todo mundo foi embora, muitas dessas flores voltaram pra casa com a gente. Eles trouxem as flores pra nossa casa também. Era muita beleza pra só umas horas. Então, muitas dessas flores voltaram pra casa conosco. Isso também foi estranho.

Quando minha mãe faleceu, eu estava na minha cidade, Saskatchewan, e ela faleceu em Prince Albert. Eu foi alguns dias depois. Ela já estava crematizada (sic). Pra meu família, a gente chamou a celebração de vida. Eu acho que nem tinha funeral. A celebração da vida, pelo nome, era pra ser uma coisa alegre, mas muita gente chorou do mesmo jeito. Essa é uma coisa bem similar. Eu chorei muito em público. O canadense chora em público. O brasileiro é menos reservado, menos conservativo nesse sentido de não ter medo de mostrar os sentimentos. De minha parte, eu chorei do mesmo jeito, do mesmo tanto. Eu chorei antes e ainda choro um pouco de vez em quando. Eu não choro mais pro meu sogro. De vez em quando, eu choro ainda pra minha mãe. Também, meu pai. Meu pai é muito sensível. Quando ele chora, se ele chora frente dos amigos, talvez ele chora, assim, quando tem um evento que lembra ele da minha mãe, ele vai chorar. É possível que amigos próximos dele também vai chorar um pouco, dar um abraço e tudo isso. Acho que a gente tá um pouco mais sensível do que o típico canadense. Olha, meu pai nasceu na Inglaterra, mas já mora aqui faz 48 anos. Ele é mais canadense do que inglês. Ele se identifica com a cultura canadense mais do que com o inglês. Ele gosta de abraçar, como brasileiro gosta, de tocar. Ele é bem físico, como eu. Minha mãe nasceu nos EEUU, ela também virou orgulhosamente canadense, mas ela também tava um pouco orgulhosa de ser americana. Meu pai tinha um desgosto de Inglaterra, ela não tinha esse desgosto dos EEUU. Ela era mais reservada. Poucas vezes, vi minha mãe chorando, mas pro meu pai, ele tava mais confortável com a ideia de chorar. Não que ele é triste, os dois sempre foram bem alegres, mas de chorar de ver uma coisa triste, de sentir com o sofrimento de alguém ou de um animal.

A celebração da vida de minha mãe foi num espaço numa empresa funerária, parecia um espaço tipo uma igreja, mas não era tão grande em termos de beleza, ornamentalmente, janelas coloridas. Era mais tranquilo, um espaço genérico. Podia ser virado bem religioso, mas as luzes e as flores pareceram bem não religioso. Escolhemos um serviço não religioso. O espaço, a parte que era pra todo mundo, não tinha comida não, nem bebida, mas tinha uma sala, do lado, onde a família esperava antes e amigos superpróximos da família. Lá tinha comida biscoitos, docinhos e bebidas não alcoólicas, como água, café, chá, k-suco. A gente tinha acesso dessas coisas antes de 
entrar na sala onde que nós fomos sentar nos bancos da frente. Já começou a celebração como se fosse uma peça de teatro. Um amigo canadense, bem próximo da família, que é bom de público, ele guiava a celebração. Ele falou da minha mãe e deixou muita gente triste, fez gente chorar e tudo, até ele chorou. Como ele sabe que a gente gosta de comédia, foi pontuado com coisas que deixava a gente rir, pra tirar um pouco da tristeza. Minhas duas tias, do lado da minha mãe, que vieram dos EEUU, elas pegaram várias fotos dos álbuns da casa, escanearam e fizeram um videozinho com música e tudo. Eles deixaram isso tocar na celebração da vida. Agora, eu tô lembrando, essa foi tipo um funerário, mas não era religiosos. Depois tinha uma outra celebração da vida num teatro. Esse foi um grupo mais íntimo com tipo oitenta, noventa pessoas dentro deste lugar. Depois tinha uma cantora, amiga da família. Ela é afilhada dos meus pais, que morou com eles nos últimos seis meses de vida da minha mãe, pra dar assistência pro meu pai. Era bem pesado pra meu pai. Minha mãe tava doente pra sete anos, mas só ficou bem difícil nos últimos oito, sete meses. Ela cantou nesse evento superbonita, mas não completou a canção toda. Ela cantou até ela não podia cantar mais. Ela chorou em frente de todo mundo. Todo mundo adorou. Era só pra cantar um pouco mesmo. A música tinha quatro minutos e ela cantou três. Depois nós fomos pra casa do meu pai, todo mundo, tinha tipo oitenta pessoas. Meu pai tinha arrumado outro amigo que é cozinheiro, ele veio pra cozinhar várias coisas, e também muita gente trouxeram pratos frios e quentes. Enfim, tinha comida demais. Tinha tudo, vinho, cerveja, wisky, Coca-Cola, água. Foi tipo uma festa. Era mais social, histórias, era bem mais leve, não tinha choros desesperados. Tinha choros e risadas, depois, choros e risadas. Foi alegre ter a família reunida, era óbvio que meu pai estava triste, ele não estava chorando. Aquela cara que conduziu o funeral novamente ele comentou coisas sérias que deixou gente triste, mas ele também contou historias que deixou gente rir também. Eu senti muito próximo às pessoas que participaram do jantar, eu conheci as pessoas mais, mesmo aquelas que eu não conhecia bem. $\mathrm{O}$ fato que eles tavam na minha casa, ocasião social em que eles acompanharam a tristeza da minha família, eu senti muito próximo deles. Fazendo uma comparação, eu não senti isso no Brasil. Também, como tinha muita gente lá, na casa do meu sogro, que eu não conhecia. Era diferente da casa do meu pai, onde a gente tava lá, comendo junto. Também tinha gente que ficou lá, como, tipo esse cara que falou no funeral. Ele é bem amigo do meu pai. Ele ficou lá com a família dele. Isso me deixou bem confortável, porque eu ia deixar meu pai lá sozinho, eu senti que meu pai ia se dá bem na companhia dele.

Uma semana depois, teve uma outra celebração mais geral com gente de teatro. Foi no auditório de um teatro onde meus pais ajudaram no ajuntamento de dinheiro para a construção. Meus pais tavam envolvidos em teatro, eles tavam bem conhecidos na cidade também. Chamava ainda celebração da vida e eles mostraram o mesmo vídeo. Era escuro igual peça de teatro, a cantora amiga cantou de novo, meu filho tinha tipo 12 anos e tocou o saxofone dele, ele tocou uma música sozinho no palco, minha filha é bailarina e dançou uma dança. A escola de balé também fizeram uma dança, tinha um cantor. Era bem bacana, mas eu também tava supertriste e, como era escuro, eu não sei se tinha outra gente chorando. Eu vi que meu pai tava chorando, eu vi algumas pessoa perto de mim, bem próximo da família chorando, assim, quietamente no escuro, tentando não fazer escândalo, sabe? Eu também, com certeza, eu estava chorando. Depois, era uma cena, bate palma, e mais tranquilo, menos traumático. Eu tenho uma irmã, em público eu choro mais do que ela. Eu não tenho medo de chorar, não. Acho que é uma coisa saudável. Eu não sei por que é bom esconder, então, eu não escondo. Também eu vi brasileiro não chorando. Eu jogo num time de brasileiros, eu sei que alguns são sensíveis, outros não. Acho que é mais uma generalização. É mais ou menos certo.

Minha família, como é pequena, quase não tem morte na família, mas a minha família brasileira é enorme, então, parece que toda semana tem morte. Lá, na hora dos cumprimentos, eu tinha mania de falar "desculpas que ele morreu", mas minha família brasileira me ensinou que não é assim. Que não é minha culpa. Seu marido faleceu, desculpa. É a primeira coisa que me vem à cabeça, porque no Canadá a gente diz desculpa, meus sentimentos, condolências, muita simpatia... Essas coisas. 
Quando me avisaram que minha mãe morreu, disseram "Sua mãe não está mais conosco". É um jeito de falar sem falar da ação de morrer mesmo. Expressões grosseiras, tem várias tipo piada.

\section{Informante 05 CA}

Meu nome é Richard, tenho 29 anos, sou canadense de Burlington, sou advogado, trabalho em Murdoch Legal e, agora, moro em Nova Yorque.

Minha avó faleceu fez duas semanas. Ela tinha 92 anos e era de Polônia. Nos dois últimos anos, ela tava com saúde meio complicada. A gente decidiu de fazer cremação e de levar ela pra Polônia pra deixar lá, ao lado de meu avô. Meu pai é da Polônia, mas mora há muitos anos no Canadá. Minha mãe já fez quatro gerações no Canadá.

Depois de falecer, no Canadá, é normal de fazer notícia no jornal onde você mora, avisando às pessoas da cidade, amigos, família, que o pessoa faleceu. Normalmente, é de cem a duzentas palavras, e se chama obituário. Esse negócio fala sobre a pessoa, como ela faleceu e quais são os planos para o funeral. A gente botou a notícia no jornal lá, avisando os amigos da família dela, que ela faleceu. Normalmente, nessa notícia, a gente avisa todos os detalhes de como vai ser o funeral. No Canadá, você tem o que se chama wake. Isso acontece na casa de funeral, e lá a gente pode fazer a incineração do corpo. Normalmente, isso acontece dois, três, quatro dias depois do falecimento. E todo mundo chega lá durante o dia ou noite, por duas três horas e você tem a oportunidade de assistir o corpo. O wake pode acontecer horas antes do funeral, ou um dia antes. Como gente são católico, isso se chama funeral de caixão aberto. Como o caixão é aberto, você pode assistir o corpo. Depende do religião da família. Às vezes, você tem um caixão que é fechado, durante esse período. Normalmente, é uma oportunidade de ver o corpo, dar notícia do que aconteceu, falar com a família e rezar lá. E, depois, vai ter um dia, vai ter o enterramento ou a cremação. Normalmente, o que acontece depois de wake, um agente de funeral chega lá, na casa de funeral, e leva o caixão no igreja, e lá, no igreja, a gente tem a missa. Normalmente, depende de religião. A gente faz a missa e depois todo mundo vai pro cemitério pra enterrar o corpo. Isso acontece três, quatro, cinco dias depois de falecimento. No wake, caixão fica aberto, dependendo da religião, ou de como a gente faleceu. Se foi de um acidente de carro, muito difícil, e o corpo foi muito mexido, a gente não abre o caixão, mas se faleceu de doença normal, a gente abre. Lá tem um pessoal do funeral que prepara o corpo com maquiagem e roupas boas pra esse wake. Os familiares e outras pessoas vão vestidos de terno preto, gravata. Muito formal. As mulheres vão de roupa preta muito formal, muito chique. Não me lembro de ver usar roupas de cor.

A gente vai esperar dois, três meses, quando o clima lá fica um pouco mais quente, porque, agora, tá no inverno pra levar as cinzas da minha avó pra Polônia. Ela morava na Polônia até seis anos atrás. Ela não tinha muitos amigos aqui, no Canadá, e a gente tem uma família pequena. Então, a gente decidiu fazer uma coisa de celebração lá, pra deixar as palavras pra ela, antes de deixar as cinzas. No Canadá, não fizemos nada de festa. Na missa, um membro da família, por cinco, dez minutos, foi lá, na frente, escolheu um passagem da bíblia pra ler e falou um pouco sobre ela, do amor que tinha por ela, sobre a família mais grande. Depois, o padre continuou com a missa. Tem flores na igreja sempre. Às vezes, você coloca as flores no caixão, porque ele está na frente do padre. Às vezes, a gente vai fazer fila pra botar flores lá em cima de caixa. E quando a caixa vai descer no enterramento, às vezes, as pessoas jogam flores em cima do caixão. Normalmente, na igreja, tem músicas religiosas, as mesmas usadas durante a missa, não de órgão, piano mais grande.

Os cumprimentos são dados durante o wake. Durante o funeral, você fala mais sobre a pessoa que faleceu. Nos cumprimentos, os convidados falam pra família: "Estou pensado sobre a família.", "Estou rezando pra vocês.", "Eu adorava/amava ele.", "Entendo como é difícil pra 
família.". É sempre difícil, mas, normalmente, você fala sobre ele. Se eram amigos, tava nas ruas com ele, talvez, vai falar como ele foi na vida, quando você estava mais próximo com ele. Normalmente, as expressões de cumprimentos são "Minhas condolências" e "Sinto muito por você e sua família". Durante o funeral, o canadense chora. É tranquilo chorar, ninguém vai te reclamar pra chorar, especialmente a família. A gente aqui não se abraça como a gente no Brasil, mas, no funeral, se a pessoa é da família, você vai abraçar. A pessoa que conhece do escritório, talvez, você só vai apertar a mão dele. Depende do relaxionamento. No wake, tem um livro pra todo mundo escrever alguma coisa e assinar. Mas isso não acontece, normalmente, na igreja. Outra coisa que você, normalmente, escolhe é uma vestido muito bonito, legal pra pessoa que faleceu, pra enterrar o corpo com esse vestido.

A casa de funeral providencia tudo para as celebrações. Normalmente, depois de funeral, as pessoas se reúne na casa da família pra comemorar, ou na casa funeral pra jantar juntos, almoçar juntos. Eu nunca fiz. Antigamente, o wake era feito na casa da família. E lá tinha comida e tudo. Pode ser que hoje seja proibido fazer em casa. Eu não sei por que não se faz mais. Na geração dos meus pais, isso acontecia, quarenta anos atrás. Eu só lio isso nos jornais, nos livros, mas não sei, na verdade, como funcionava.

Levou quatro dias do falecimento da minha avó pra cremação. Quem tem família em outras partes do mundo, espera todo mundo chegar, mas não tinha ninguém pra chegar da Polônia.

Meu irmão faleceu quando eu tinha nove anos, e ele tinha treze anos. A gente tinha um wake, e alunos da classe dele chagava no funeral e, depois, foi enterrado lá, perto da casa dos meus pais. O wake foi na casa de funeral. Foi uma coisa bem difícil. Chegava quase 80 alunos e todo mundo chorava, muita gente chorando. No funeral, você não fala com a família. O padre fez a missa, depois, a gente vai pra enterrar o corpo. Não lembro muito o que aconteceu depois, não lembro de um festa qualquer. Foi muito difícil. Ele tinha um problema de coração e aconteceu um dia de noite. Ninguém esperava. Até hoje, é difícil pro meus pais, eles ainda choram. Agora, só tem eu. Na igreja, tinha muitas flores, mas poucas vela, porque foi durante o dia. Teve obituário no jornal pra avisar todo mundo.

\section{Informante 06 NO}

O funeral no Brasil é praticamente feito em 24 horas. Dizem que pode ser em até dois dias, mas pelo que vejo as pessoas correm pra enterrar logo. Isso me chama muito a atenção porque, na Noruega, não é assim. O resultado que eu senti é que as pessoas estão ainda muito mexidas, muito consternadas, e o ambiente é extremamente triste com muito choro, é um negócio, claro que muito emocional, pois, nos dois casos, a pessoa passou por alguma coisa, no caso um deles foi acidente, o outro, uma doença. De qualquer maneira, as pessoas estão despreparadas, então, sofrem muito no dia seguinte. Me chamou a atenção também a falta, digamos, de participação das pessoas, fica junto sim, fica junto mas não há uma cerimônia, uma coisa organizada pra pessoa participar. Num deles que não era religioso, teve até um pequeno discurso, mas fora isso teve só a parte de enterro mesmo. Eu senti muito falta de um lugar pra cerimônia. Normalmente, tinha um velório que era numa capela, um ambiente que parecia mais um local assim de quando você podia ficar com as pessoas, mas não era um lugar religioso e, depois, a cerimônia era feita fora do caixão, era uma coisa muito rápida, sem música, sem canto, só mesmo as palavras e depois acaba.

O que mais me chocou... Eu achei tudo extremamente triste, eu acho até hoje que as pessoas lidam com a morte de forma diferente do que na Noruega. Não só o funeral é muito triste, mas ainda tem a missa de $7^{\mathrm{a}}$ dia, de 30 dias, 1 ano, e é tudo triste, é meio como se você fica remexendo nas tristezas da pessoa ter-se ido sem recordar as coisa alegres. Na Noruega, nunca fui 
num funeral católico, sou luterana, e as missas na igreja luterana são muito bonitas. Só existe a missa de corpo presente.

$\mathrm{Na}$ Noruega, é muito importante que todas as pessoas da família, todas as pessoas chegadas participem, e se espera pelo menos uma semana, às vezes, até mais tempo, pra que todos cheguem. Os corpos são colocados num lugar gelado. O hospital prepara, depois, a agência funeral cuida mais do corpo. O funeral não dura uma semana, você espera uma semana pra fazer a cerimônia, que é de corpo presente sempre, uma missa ou outra cerimônia não religiosa. É muito, muito bonito, a igreja toda enfeitada com flores, o caixão enfeitado com manto e flores, buquês de formatos diferentes. A missa é uma cerimônia religiosa com músicas, muitas vezes, quase sempre, é a família que escolhe as músicas. Às vezes, a pessoa deixa até anotadas as músicas que gostaria que fossem tocadas. Não precisam ser religiosas, podem ser músicas mais populares, mais conhecidas. O padre que fez a cerimônia fez um discurso muito bonito, contando coisas da vida do falecido e, depois da cerimônia, todo mundo que estava na igreja foi para o salão de festas da igreja. Isso quase sempre se faz, ou no salão da igreja, ou na casa da pessoa, mas minha avó não quis fazer na casa dela. Então, fomos pro salão da igreja e aí você serve sempre café, chocolate, refrigerante, comida. Pode ser quente, ou sanduiches, canapés, docinhos. É muito importante que tenha comida. É uma comida que faria pra uma recepção. Normalmente, você pede a uma firma pra fazer isso, ou a família se junta e leva vários tipos de salgados, bolos e docinhos.

Hoje em dia, é muito comum você encomendar a comida. As pessoas que ficaram têm que se ocupar com a decoração, e faz-se uma lembrança com foto da pessoa que faleceu e um poema, letra de música, uma coisa que a pessoa leva. Esse planejamento é muito importante. Tudo tem que ficar bonito, a decoração, as toalhas... Depois da cerimônia religiosa, alguém faz um discurso e depois quem tem vontade conta os casos da vida do falecido, são histórias muito engraçadas, a gente morre de rir. Saímos do evento sem chorar, sorrindo. Lembrando que a pessoa viveu uma vida boa. Foi um momento muito bom em que a família estava junto. As pessoas de fora só vão no dia do enterro. A pessoa pode pedir pra ver o corpo, mas ele fica na geladeira. Mas pode marcar uma hora, principalmente, quem chega de fora.

Na cerimônia religiosa, o caixão é fechado, não é comum ver o corpo. O tempo pode ser de 5, 7 ou até 10 dias. Lá se diz que "A pior vergonha que a pessoa pode passar é não ter ninguém em seu funeral". Toda vez que alguém morre, é colocado no jornal. Todo mundo comunica pelo jornal e coloca se quer que mande flores ou que se faça doação pra uma instituição. A pessoa pode pedir pra não gastar dinheiro com flores e fazer a doação. A cor das flores depende do gosto das pessoas ou da idade. A igreja fica cheia de flores. As pessoas tiram fotos das flores do caixão. É muito importante que fique tudo muito bonito, um visual agradável. Na Noruega, todos os cemitérios ficam ao lado, ou ao redor da igreja. O governo oferece o espaço para o enterro. O cemitério é um lugar muito bonito. É como um parque. Aqui, no Brasil, existe um comércio pra pessoa pagar pra poder ser enterrada.

Hoje em dia, muita gente faz cremação, meu avô foi cremado, eles não levaram o caixão pra fora da igreja. Após a cerimônia, o caixão vai direto pra cremação. A família não participa. Quando recebe o pó, chama só os filhos.

Nem sempre há um livro de assinaturas, mas tiram fotos.

Só cumprimentam com aperto de mão, abraços só se for alguém muito, muito próximo, não é comum. $\mathrm{O}$ momento de abraços entre os familiares só em casa, em público não. Dizem minhas condolências, meus profundos sentimentos.

A mesma igreja e o mesmo cemitério são usados por famílias pobres ou ricas. As flores, o caixão e o anúncio no jornal são pagos à parte. A igreja faz parte do governo, é custeada pelo governo. Se a pessoa pertence a outra religião ou é declarado ateu, quando nasce, é uma coisa automática. A pessoa nasce e já faz parte da igreja. Para não fazer parte tem que avisar. Quem é ateu pede pra usar a igreja, pois tem uma cerimônia própria. Mas tem direito ao funeral. 


\section{Informante 07 NO}

Tenho 23 anos e moro em Aelesund. Quando meu avô morreu, puseram ele na casca e tudo, já puseram roupa, já era preparado pra ser enterrado, já estava com terno, tudo. Ele ficou na casa da minha vó. Na nossa casa, ele ficou lá uns dias, acho que quase uma semana, porque, normalmente, quando uma pessoa morre, na Noruega, leva uma semana ou mais. Demos flores pra ele. Era criança mesmo, então, foi o primeiro enterro, assim, funeral, enterro o processo de quando alguém morre, porque ele foi o primeiro parente meu, nosso que faleceu. Quando criança, eu nunca ligava, o meu avô está morto, mas era natural pra gente, porque meus pais explicaram bem para nós como que meu avô morreu. Ele foi no hospital do coração, eles eram honestos com as crianças falava mesmo que ele morreu, que agora ele vai, que agora ele não está aqui mais com nós. Eu tinha 5 ou 6 anos, foi em 1996, eu ia fazer 6 anos, isso foi em março de 1996. Eu acho que ele ficou quase uma semana em casa. É, ele ficou numa sala que era em cima na casa da minha vó, e acho que ele ficou lá. Era março e o tempo já era frio, deixaram ele lá com a janela aberta. Os detalhes eu não lembro muito bem especificamente. Mas eu lembro que ele estava lá. Já estava preparado pra ser enterrado. O dia de enterro dele, botaram só ele na casca, fecharam a casca. Aí, eles levaram, eles trazeram ele de carro pra igreja onde ele ia ser enterrado. Então, acho que foi isso mesmo, ele já estava preparado, foi só fechar a casca, e ele foi direto.

Não era quieto. A família estava lá, meus pais, meus tios, minhas tias, a irmã dele. A família mais perto estava lá na casa, porque é costume os homens levantarem e trazer a casca. Então, tinha um lugarzinho que ninguém estava segurando, porque dá pra segurar em tudo, é tudo preparado. Eu lembro que eu peguei o lugar que ninguém estava levantando essa casca. Então, fui e a família toda ficou chorando porque, né, eu que também queria ajudar meu avô, eu tinha quase seis anos. Então, eu era novinha, então, eu também queria ajudar, eu era pequena, mas eles estavam na escada então dava pra eu segurar também. Eu queria, né, ajudar a levar meu avô pra igreja, ajudar a levantar. Aí não tinha música nem nada, só quando fomos na igreja. A cerimônia lá que toca música de órgão.

Na igreja, é assim, você chega, normalmente, é a família que chega mais cedo. Aí, chegamos, vêm as pessoas que botam a flor, que decora, né, coloca flores em cima, em volta, velas. Assim, eu acho que foi um enterro que tinha vela, botaram vela, castiçais. É bem simples mesmo, mas é muita flores, porque normalmente as famílias compram flores e tem sempre um recado ai no enterro. O padre fala: "Agora a família que vai ler essas cartas que estão nas decorações de flores". A família vem e lê, ou normalmente as pessoas que fazerem a decoração, eles também leem.

Então, é isso aí, você chega cedo, você senta, aí, você já está vendo mais pessoas. A família é a que senta na frente, e todo mundo se senta mais atrás. Ninguém quer se sentar mais na frente que é amigo, normalmente, se senta muito atrás. Não querem se importar, isso é uma coisa norueguesa que você que tem muito, normalmente, eles se sentam muito pra trás porque não querem incomodar nem nada. Eu sempre vejo isso nos enterros, agora, né, que eu já estou mais velha, já vejo detalhes do enterro. A minha vó faleceu ano passado, e a minha tia, tia do meu pai, faleceu agora, esse ano em, agora em junho mesmo. Mais detalhes, os dois mesmo eu lembro tudo.

Então, eu já fiz parte dos enterros porque eu canto. Normalmente, eu canto nos enterros desde a minha vó, foi a primeira vez que eu cantei num enterro. Então, eu lembro muito do processo. Chegamos cedo, né, vimos foi uma mulher que fez a decoração. Então, uma hora depois mais ou menos chegavam as pessoas era, deixa eu ver, aí, chega toda família e os amigos. A família normalmente e, depois de um tempo, né, já começa a cerimônia. O padre vem, ele fala "hoje vamos enterrar" e fala o nome, aí, fala normalmente. O processo é que o padre vem nas nossas casas, eles perguntam à família quem ela foi, como é a história dela, quem são os filhos, como era a vida dela quando era mais jovem, ela casou com quem. Sempre pergunta, né? Aí, ele fala, na cerimônia, essas coisas que ele fica escrevendo porque a gente fala histórias, principalmente, da minha vó porque ela ajudava muito, ela era muito, era uma mulher que todo 
mundo conhecia ela, todo mundo, se passava na casa dela, falava: "Oi, e aí, tudo bem? Como está a vida? Como está tudo aí?" Sempre que passavam, falavam com minha vó e contava as histórias de quando eu era mais jovem, quando era mais nova. Mas, aí, como a gente visitava a casa dela, ela sempre gostava de dar, né, de dar biscoito. Ah, você já comeu? Deixa que eu faço um café". Essas coisas. Então era o que o padre fala da vida, como ela nasceu. Minha vó tinha muitos irmãos e irmãs, então, falava que ela era a mais nova de todos, então, fala, né, da vida dela. Aí, tem música que normalmente tem um organista que ele toca no órgão, eu cantei no começo. É música tipo, a música era amazing grace, que é uma música inglesa muito bonita. Aí, eu cantei essa, aí, o padre falou, aí, tocaram uma música, assim, salmo norueguês. Muito bonito! Aí, que também os meus pais escolheram a música que eles também tocaram no enterro do meu avô, que é marido da minha vó. Aí, eles escolheram mais ou menos a mesma música porque, né, eu acho que meu avô queria, assim, queria a mesma música. Então, escolhemos isso porque achar música pra um enterro é difícil, porque você nunca sabe, é muita música que você pode escolher normalmente. Você também canta essa música quando o homem toca o órgão. Aí, todo mundo canta, aí, né, qual música que todo mundo conhece? Porque ninguém quer tocar um órgão, e ninguém estar cantando. Essas coisas é difícil, mas acha. Ah essa aqui eu conheço, aí, sempre me perguntam por que eu trabalho na igreja há tantos anos. "Então, Elisa, alguém conhece essa música mesmo aí?" eu falei: Ah, conhece sim, conhece sim porque já é uma música que dá pra usar em outras ocasiões.

Ela morreu, assim, num hospital no asilo e foi de repente, porque ligaram pra nossa casa, pro meu pai porque meu pai que é o filho dela. Contaram pra ele porque a minha vó já estava ficando ruim, né? Ela não estava melhorando, ela não estava querendo comer, que a saúde dela estava piorando muito rápido. Então, uns dias, ela já faleceu, mas foi, não foi de repente, não foi aquele trauma, foi assim calmo. Todos visitamos ela, falamos com ela e, então, ficamos juntos com ela nos últimos dias dela. Eu lembro que eu fiquei lá no último dia dela. Eu cheguei de onde minha faculdade, da cidade onde eu vou pra faculdade. Aí, eu cheguei tarde, fui direto pro asilo, sentei lá com ela até quatro horas da noite, da manhã. Eu e o tio sentamos lá com ela. Não queríamos que ela ficasse sozinha nos últimos porque ela já tava, ela não falava nem nada, ela estava dormente mesmo. Mas eles falam que a última coisa que sai quando morre é ouvindo né, que ela sempre vai ouvindo a nossa voz, né? Ficamos falando normalmente mesmo e aí ficamos juntos que ela sempre ouvia as nossas vozes. Ficou lá, no asilo, porque tem um lugar que usa, né, que o falecido fica até o funeral. É, ela ficou sete dias mais ou menos. É, foi uma semana, é isso, ela faleceu quinta-feira de manhã e uma semana depois ela foi enterrada.

É a funerária que avisa o padre. Aí, o padre liga pra família e pergunta que horas e que dia pode encontrar com a família. Aí, todo mundo se junta e fala histórias da pessoa que faleceu. Falamos as histórias da minha vó essas coisas, então, e é, e somos nós que ligamos pra funerária pra marcar o dia que dá pra enterrar. Às vezes, a funerária não tem tempo mesmo pra enterrar a pessoa uma semana depois. Às vezes, é mais de uma semana, mas normalmente é dentro de uma semana. Depende se eles têm muito trabalho, é isso mesmo, é assim. Deixa eu ver, normalmente, são meus pais que fazem isso. É, então, somos nós que ligamos pro jornais e, é a funerária que liga, mas a família que escolhe que são as palavras que vai ser escrita, quem vai incluir o quê. O texto é a família que escolhe, mas é a funerária que liga.

Normalmente, fala Condolências para você e sua família, Estou pensando de vocês, é isso sempre, né? Se alguém da minha família faleceu, vem e fala Condolências. Em norueguês é Condoleira. Também, se tem uma situação que tem alguém muito doente, né, que está com câncer, está morrendo, né, que está na fase terminal, aí, fala Condolências, tipo assim, Que triste, Tô triste, ai é condolências, né?

Eu sou uma pessoa que choro muito. Eu já chorei antes quando meu pai me falou que ela não estava bem, ela está ruim, aí eu já choro. Eu chorei, chorei, devo ter chorado uns 7 dias ou mais. No dia do enterro, eu chorei, chorei demais, choramos, assim, mas eu não sei pela minha família, porque choraram, mas não mostraram assim. 
Os homens não choram. Acho que raramente eu vejo homem norueguês chorar, eles ficam quietos, assim, quase não falam, ficam quietos. Tem a cara que mostram os sentimentos que são tristes, mas, assim, tem uma fica muito sério, que eles não mostram, você não vê que eles estão sofrendo de um jeito que alguém que, eles são reservados. Mas as mulheres, alguém chora, alguém, como os homens, ficam assim quieto, mas chora. Então, eu sempre observo que homens ficam sempre reservados, bem quietos, não choram, assim, uuuuuu, muito, mas ficam reservados. Você não ouve eles, mas as lágrimas caem, você não ouve muito que estão chorando, mas ficam sérios. Você só vê que a lágrima cai, mas fica calmo, mas isso mulher de idade. A juventude, já vi gente que faz igual eu, soluçando, chorando e mostrava, mas, normalmente, são quietos e reservados, não falam muito.

Tem abraços, não, não tem muito abraço, mas depois a família fica todo lá fora, porque levantou a casca e traga pro carro, né? Aí, vai todo mundo atrás da casca, os amigos atrás e vai todo mundo saindo da igreja. Aí, fica todo mundo lá fora, perto do carro, fica um momento quieto, todo mundo, tudo calmo. Aí, já, né, fecha o carro, o caixão vai dentro do carro. Aí, o carro dirige pra, como é, normalmente, vai pro crematório. Aí, depois, todo mundo se junta lá, aí, dá abraço ou, né, aperta a mão, fala Minhas condolências. O abraço depende de quem que é. Se é homem, eles não dão muitos abraços, mas, assim, Minhas condolências, assim, com cara séria, mas as mulheres abraçam, foi isso que eu percebi.

Normalmente, tem ocasiões que sempre se junta, mas depende de quem que se junta. Mesmo assim, normalmente, os amigos da família, se é perto da família, eles vão, se juntam na reunião depois da igreja, se não, só a família mesmo, só a família mais próxima do falecido. Acho que nunca fui numa reunião dessa com música, não nunca, então não tem música, depende da família, se alguém acha que botar uma música ajuda faz, mas normalmente não se usa música. Normalmente, tem tipo de sanduiche norueguês, então, é pão com alface, uma carbonada, e um cebolas é o que todo mundo gosta. Também, tem com camarão, com maionese e camarão. Normalmente, tem bolo, tipo bolos noruegueses, geralmente é, é bolo, depende muito da família. Às vezes, é amigo da família que faz e traga: "Oi, eu trouxe um bolo pra você, Minhas condolências". Ou a família próxima faz bolo ou encomenda. Nós encomendamos bolos e os sanduiches, não fazemos. Tem um tipo doce, um doce norueguês, que também se come, mas normalmente é bolo. É bem simples mesmo, é comida, mas não é muito, não é aquela festa. Aí, tem café, tem chá, tem refrigerante, acompanhando a comida. Aí, todo mundo se senta junto, fala. Todo mundo fica dando papo, normalmente, é da pessoa que tem falecido, então, fala histórias. Aí, pergunta se alguém quer falar alguma coisa, e fala. Isso eu lembro da minha vó, que todo mundo, né, que é amigo da família, fala: "Ah, eu lembro quando ela tinha tanto e tantos anos. Eu lembro quando meu avô e minha vó se casaram”. Era tipo assim, histórias, ou quem que ela conhecia. É histórias, aí, todo mundo fica falando as memórias, impressão da minha vó, que pessoa ela era na impressão deles. Aí, eu achei muito bonito quando eles falaram as histórias, as memórias, né. Eu achei isso muito bonito porque eu também conheci minha vó de um outro jeito. E, aí, eles também mostram fotos, se tem fotos, se tem álbuns, passa, todo mundo fica olhando: “Ah, eu lembro essa foto, isso foi 20, 30 anos atrás, foi ali e tal”. E, aí, tem pessoas que podem falar da história inteira. Só vendo o foto, é uma grande história atrás desse foto. É muito especial, porque eles falam isso: "Aqui foi na casa do tal, e era irmão e era parente da sua vó e tal". Você fica emocionado, curioso quem são eles, e sai chorando pra ouvir que essa história eu nunca ouvi, e, aí, fico perguntando, isso que eu gosto muito, mas depois do enterro, porque o enterro é tão triste pra mim, mas é bonito também. Eu choro muito, eu fico triste, mas depois quando todo mundo se senta e conta as histórias e tudo, eu me sinto muito, liberada dessa sensação muito triste, porque todo mundo se senta, tudo está mais calmo, tá todo mundo junto. Aí, eu gosto mais, eu adoro enterro. Não que eu goste, mas é uma cerimônia muito bonita, mas se é um parente de você, é outra coisa, dói mais, é outra coisa. Então, eu acho melhor ir depois que todo mundo se reúne e todos ficam falando. Aí, é muito legal, eu vou conhecer amigos da minha família, da minha vó que eu não conheço, que me conhece, mas eu não: “Ah, quando eu te vi, você só tinha 3, 4 anos. Ah, eu te vi no enterro do seu 
avô, do seu tio, mas você era muito nova, então, você não me lembra”. É conhecendo de novo essas pessoas e é muito especial, pra mim, eu achei muito especial.

As pessoas enviam flores com mensagens, mas eu nunca fui num enterro que alguém trazeram, cartão, mas tem, nem sempre, não nos enterros que eu fui. Em alguns funerais, tem livro de assinaturas, que a família providencia para comunicar a morte.

Quando minha vó faleceu, ligaram pro meu pai e disseram: Ela já passou, Ela já se foi. Eles ligam novamente logo depois. Ai ligam pro mais próximo, e falam: Olha, tudo bem, olha sua mãe faleceu, ela já foi. Também Ela adormeceu. Aí falam Minhas condolências. Eu e minha família fizemos que todo mundo foi no asilo, no dia que ela faleceu, e demos nosso último tchau. Aí, falamos alguma coisa. Lembro que minha mãe falou uma coisa pra minha vó, umas palavras pra dizer adeus pra ela. Ai todo mundo se junta, alguém chora. Eu lembro que o único menino totalmente norueguês que é meu primo ele chorou, eu lembro muito porque ele foi o único dos homens que chorou, que mostrou, nesse momento. Eu chorei, sempre, eu chorei, mas eu vi que ele também chorou. Então, todo mundo se junta. Eu não sei se todas as famílias fazem isso, mas eu acho que é normal que se juntam a família mais próxima se junta e dar o seu adeus.

Em público, eu choro, mas, raramente, vejo alguém fora da família chorando. É tudo reservado, parece que são todos severos, não choram.

Aqui não é costume ir passear no cemitério, pra algumas famílias é costume passar no cemitério pra visitar a família. Fala mesmo: "Vou visitar a minha vó". Eu não sou muito pra visitar, eu posso ir lá, pra mim não é, não tenho costume pra fazer isso. Já minha melhor amiga, ela também perdeu o avô dela, ela já foi lá duas ou três vezes, e ele faleceu foi agora, no mês passado. Acho um pouco sinistro ir lá passear. É o lugar dos mortos. Acho que nunca vi ninguém andar no cemitério pra passear.

É comum usar velas no velório, na igreja. No cemitério, você compra velas que dura, dá pra botar na lápide, você compra umas velas que dura, que pode queimar, é mais ou menos sete dias. Na igreja, no funeral, também tem, mas é bem discretamente, depende tem umas que usam as grossas, mas tem umas que usam as finas, é poucas velas, e uns são perto do caixão e umas são longe, depende muito, normalmente, se usa, quando se usa uma duas, às vezes, quatro, mas dois é mais comum.

Aqui não se beija, de jeito nenhum, o rosto da pessoa falecida. Não, não de jeito nenhum. Só quando minha vó e minha tia faleceu agora, que eu beijei o rosto da minha vó, mas não se faz de jeito nenhum. A pessoa vai perto, talvez bota a mão em cima da mão do falecido, mas não beija nem nada. Isso não é comum de jeito nenhum.

No próprio dia que a pessoa tem falecido que a família pode ir e dar seu último adeus, mas é só no dia que faleceu, ela está no próprio quarto dela. Por exemplo, a minha vó, ela ainda estava no quarto no dia em que faleceu, ela estava lá na cama tudo calminha, bem bonito mesmo, acenderam velas no castiçal. Quando chegamos, era tudo escuro, mas tinham velas, vela pequena. Depois, leva o corpo pra sala fria. Aí, família que não pode chegar no dia pode vir nessa sala fria. Mas não é a mesma coisa. É você mesmo que escolhe se quer ver o falecido ou não, porque tem pessoa que não quer ver essa pessoa morta, porque vai ser outra memória, vai sempre ver essa pessoa morta assim toda gelada, não tá vivo. Eu acho isso traumatizante, né, eu acho que fica uma trauma, que não é confortável. Comigo não tem problema, eu sempre vi os meus parentes. Não, mas eu não vi meu tio, eu lembro que eu não vi ele quando ele morreu, porque foi muito doente, foi câncer e foi muito de repente. Ele faleceu muito rápido, quando descobriram que ele tinha câncer no cérebro. Ele era um tio do meu pai, então, era um homem de idade, e, quando descobriram, ele já estava morrendo mesmo, ele já estava no estado terminal, mas foi rápido. Em dias, ele já faleceu, ele estava com tanta dor que ele ficava se mexendo na cama. Acho que, por isso, que eu via ele nesse, que ele estava todo se mexendo e batendo as mãos e fazendo barulho de tanta dor que ele estava, muito sofrimento. Eu acho que parecia que ele sofria muito, aí, ela nem foi lá pra ver ele, porque ele faleceu no próprio hospital. Eu num queria ver ele, eu acho que ia ficar com aquele sentimento que não era confortável pra mim, porque ele sempre foi um homem 
muito legal. Assim, ele era muito bom, tinha um coração muito bom, sempre, assim, o jeito dele era uma pessoa boa. Acho que não ia, eu já vi ele com tanto sofrimento, que eu acho que talvez era melhor ver ele sem morrer porque ele já estava calmo, a dor não estava sofrendo mais, mas ai eu não vi ele. Mas, para mim, não é uma problema que eu não estava lá, mas o meu pai, minha vó e minha tia, o tio do meu pai foi lá. Mas acho que quase ninguém foi. Acho que só ela e talvez meu pai e minha tia. É, só eles mesmo, mas não a família inteira, ninguém se juntou.

Ele foi cremado. Ele, minha vó e minha tia que faleceu agora. Ele foi cremado depois do funeral da igreja.

Assim, a minha vó ficou nessa sala fria. Acho que foi até o dia anterior. Não sabemos, ninguém tem certeza, mas levam ela pro crematório, porque o crematório não é na igreja, então tem que dirigir ela para o lugar do né, para o crematório, então esse processo eu não conheço, assim quanto tempo que passa.

Atualmente, eu já acabei meu estudo, sou uma professora formada. Eu já estou trabalhando como professora de norueguês. É só um curso, eu tô dando aula de um curso de norueguês, para trabalhadores estrangeiros. É numa firma, isso que eu tô fazendo, é uma escola particular, aqui na Noruega. Então, tô fazendo isso agora, mas não vai durar muito tempo, agora, porque já está acabando as aulas.

Ah, eu tenho uma amiga que, quando o avô dela morreu, ela chorava, ela chorava muito. Ele morreu de câncer, ela já esperava que ele iria falecer um dia. Então, é isso mesmo, ela chorou muito, aí também no enterro. Eu podia ir, mas eu nem perguntei. Acho que ela queria mesmo que, porque ela não gosta muito que fica perto dela, assim, quando ela está triste, aí, eu acho que ficar com ela nesse dia, ela não ia, não ia melhorar a situação dela. Mas eu falei muito com ela, eu mandei mensagem, eu liguei, eu perguntei se estava tudo bom com você. Ela respondia sim, sim, estou melhorando. Falamos, né, porque ela é minha melhor amiga, mas ir no próprio enterro não ia ajudar ela ou a família, porque estava todo mundo. Aí, porque ele morreu desse jeito, foi muito, triste. Eu também fiquei muito triste quando fiquei sabendo, ela demorou pra falar também, ela estava tão, tão, a família estava tão desolada, então, já viu. Aí, mas agora ela está bom já, mas foi um tempo igual. Eu, toda vez que eu falava da minha vó, começava a chorar lágrima o tempo todo. Oh, tristeza! Aí, todo mundo nem pergunta, se eles sabem, se te conhecem muito.

Aqui, normalmente, se encomenda flores, mas leva, pede pra entregar pra própria família, não leva na igreja. Às vezes, também, mandam cartão de presente pra comprar flores eles mesmo, que também pode ajudar o próprio enterro. Aí, dizem: "Aqui um cartão de presente com tanto, tanto dinheiro" ou "Segura esse cartão para comprar flores para o enterro, para vocês". Isso também se faz, e muito, varia um pouco. Alguém vai na casa com flores e dá. Isso não é comum, normalmente, manda vir alguém: "Oi, eu tenho umas flores dessa família". É encomenda e alguém traga para eles, aí, vem o cartão sempre. Quando lê: Condolências ou Tô pensando em você e na sua família, fulano de tal.

Tem pessoas que publicam no jornal que, em vez de flores, enviarem um envelope com doação para o Instituto de Câncer, pesquisa do câncer, ou outra instituição.

\section{Informante 08 NO}

Eu trabalho num escritório de arquitetura, trabalho com planejamento de cidade, planejamento urbano. Eu estudei por aqui também. Eu fiz arquitetura, mas eu estudei mais as partes urbanas. Aí, no Brasil, eu fiz aulas de capoeira e, até hoje, dou aulas de capoeira aqui na Noruega. Tenho 35 anos.

Morei no Brasil por 11 meses. Em 1996 pra 1997, quando eu tinha 16 anos. Eu chegar pra um quarto que tinha um caixão. Isto porque a família onde eu morava tinha que ir pro 
cemitério. Então, não atendi o funeral mesmo, mas vi o caixão. Eu fiquei assustada porque eu nunca tinha visto essa parte antes. Achei o quarto muito escuro e não conhecia ninguém lá.

O funeral aqui, na Noruega, o último que eu fui foi o da minha avó. Eu fiquei junto com meu irmão na porta da igreja. Não era uma igreja, era uma capela, menor, num lugar pequeno. Eu vim junto com meu irmão distribuindo os folhetos e recebendo as pessoas entrando na igreja. Foi nossa família toda e mais pessoas da vila mesmo. Eu sou de uma vila pequena, não moro mais lá e fez tempo que não via essas pessoas. Dessa parte, foi boa ver e receber. Dentro da igreja, o funeral, foi colocado tudo ali: as flores da toda a família, as flores de amigos e tal e, nesta igreja, serve também como, assim, um local de comunidade. Tinha velas, tinha músico pra tocar piano e padre. A igreja é protestante. Na Noruega, a igreja é protestante, é a Igreja Estado. É mais formal que o país tem esta parte. Não conhecia ele antes, mas a maioria dos padres, na comunidade, eu já tenho visto. Ele deu uma pequena palestra. Eu cheguei, também, pra fazer o folheto que tem e escolher as músicas que a gente cantava para esse funeral. As músicas que a gente escolheu, era assim uma música antes para a aberta, e uma antes da palestra que o padre dá, e uma depois, e uma depois lá, fora, né? Não tem programa, mas tem só as músicas nessa parte. Aí, tem o que toca piano, o organista e um solista, acho que tocava flauta.

Quando ela morreu, ela tava morando no hospital, no lar. A família entrou em contato com uma agência funerária e eles têm suas maneiras de fazer que ajuda também. Eles têm um programa pra seguir. Eles sabem qual é o procedimento. Eles tiram o corpo do hospital e levam para a agência funeral pra preparar. Ela morreu no dia 6 de 4, e no dia 12 teve o funeral, uma semana. Ela faleceu à noite, e, no dia seguinte, a gente voltou lá pra ver ela. As pessoas lá, do hospital onde ela morava, tinha preparado ela, pra gente ver ela mais uma vez. Aí, foi só eu e meu irmão e uma irmã menor. Foi a primeira vez que, assim, a gente tinha um familiar próximo pra ver. Deu vontade de beijar, mas a gente não sabia se podia.

A gente fez os folhetos, porque a gente queria fazer, mas não é comum. É a funerária que faz. Todos os funerais aqui tem anúncio no jornal, até aqueles que não têm família mais próxima. Aí, eles colocam pouca coisa, mas eles colocam no jornal, pras pessoas, às vezes, aparecerem no funeral. Não tem um convite imprimido. Não é preciso todos levarem flores. Sei que alguns têm, assim, um pai de amigos que sempre dá flores, porque eles não podem estar junto. Tem uma parte que vai nos funerais, e tem outra que manda flores. Dão o respeito e dão as flores e estão lá presente, mas nem todo mundo precisa ir. As flores ficam por cima do caixão. Ele fica fechado. Também as flores podem ficar ao lado ou em volta. Antes do funeral, a minha mãe foi ao escritório do padre, na igreja, para falar coisas sobre a minha vó. Além do padre, a família fala também. Elas falam uma história, assim, da vida da pessoa e a família, também, pode contar essa parte e dar um recado pessoal do que eles querem falar. Também, nesse caso, assim, agradece a todo mundo que cuidou dela no hospital e a todo mundo que foi visitar ela, regularmente, quando ela tava lá. Ela foi sepultada. Isto é comum na vila onde ela morreu. Às vezes, no jornal, a família coloca que, em vez de flores, a pessoa pode fazer uma doação. Depois do enterro, a gente reuniu a família, na fazenda, mas tem alguns que diz, também, naquele anúncio do jornal que não vai ter nada depois, que vai encerrar na parte de fora, do enterro. Mas a minha família fez. Em geral, a roupa é preta, né? Mas não é nada especial. Só roupa escura, né? Na fazenda, foi um lanche, mas a minha mãe arrumou isto de um lugar. Assim, a gente não fez o trabalho de fazer a comida, isto foi comprado em outro lugar.

Na hora dos cumprimentos, as pessoas falam "condolências". Os amigos mais próximos me deram um abraço, e os que eu não conheci tanto me deram a mão, e eu apertei a mão de todos lá. A família mais próxima pode chorar na igreja também. Na fazenda, abriu pra mais pessoas falar da minha avó também. Isto foi bonito. Também, foi uma reunião de família, assim, onde teve sorrisos e fotos tiradas juntos e tudo também. Mas, também, as pessoas estavam mais abertas pra falar um pouco mais também. Se a família tivesse de músicos, teria músicas, mas a gente não toca instrumentos. Não teve música, só a gente mesmo. 
Para comunicar a morte, sem falar a palavra morreu, as pessoas podem dizer passed away, "Ela passou", "Ela se foi". No caso da minha vó, eles disseram "Ela dormiu" e "Ela endormeceu". Aqui, quando um cachorro morre, dizem "Ele vai caçar pra sempre". Também pode falar de uma pessoa, assim, de forma grosseira.

Quando sabem da morte, amigos próximos visitam a família. Em geral, é mais ou menos uma semana, e acho que tem um pouco a ver com as igrejas e os padres pra preparar as pessoas e o andamento. Acho que, como a empresa funerária tem bastante, eles sabem bem como fazer, mas preparar as pessoas e a família mais próxima e tudo que vai acontecer no funeral mesmo, acho que uma semana é comum pra demorar da morte mesmo pro funeral. O cemitério é perto da igreja. Ele é baixo, é de grama com pedras.

\section{Informante 09 NO}

Tenho 45 anos, sou formado Assistente Social e sou assistente social da Igreja Norueguesa dos Marinheiros que fica na Gávea. Aquele ponto de cultura, de apoio pra noruegueses. A gente vive nessa igreja.

O que acho estranho no funeral aqui, no Brasil, é o fato de ter tanta pressa. Essa questão, pelo menos, no Tocantins, que depois de uma pessoa morreu, você ter quase vinte e quatro horas pra isso acontecer. Na Noruega, a gente faz tudo em uma semana, um pouco mais. Você tem um tempo, a tranquilidade, até a questão de sentir as dores. Não tem aquele estresse que a gente sente aqui, né? Velório, também, é uma coisa meio estranha pra nós, né? A questão que você vai, você põe o corpo dentro da casa, normalmente, na família. Coisa muito esquisita pra nós, quando eu cheguei aqui. Eu, também, eu fui, acho, que umas quatro vezes quando foi uma criança que faleceu. E, também, foi meio, assim, estranho essa questão de ter esse caixa aberta. Outra coisa que eu achei muito estranho, também, foi outra coisa, também, porque, aqui, a gente sempre trabalhou com pessoas carentes, né? Então, muitas vezes, eu tava tirando fotos das famílias e, às vezes, tinha famílias que não tinha foto do filho e pedi pra eu tirar foto com o filho já morto. Foi uma coisa superesquisita pra nós. Assim, muito estranha mesmo. Então, a coisa que mais toca é aquele rapidez, aquele estresse de não ter a possibilidade de refletir, de sentir primeiro a morte de uma pessoa que você gosta. Você só tem que correr pra resolver tudo. Muito complicado, acho pra um ser humano. Imagino que isso acontece só nas famílias do interior e, principalmente, bem carentes. No Tocantins, na cidade onde a gente viveu sempre foi assim, sempre na casa da pessoa.

Na Noruega, pra falar a verdade, eu conheço mais pessoas, eu acho, que faleceu aqui, no Brasil, do que na Noruega. Não tem muito, assim, mortes violentas. Isso é uma coisa meio diferente do que aqui. Lá, eu acho que eu nunca, na minha vida, fui num funeral de uma criança, nunca. Sempre foi de uma pessoa mais velha, ou, como assistente social, com pessoas que utilizavam drogas, né? Por isso, também, normalmente, a morte não é tão chocante na Noruega. Eu posso, por exemplo, falar que, o ano passado, em acidentes de carros, na Noruega, morreu duzentos e cinquenta pessoas. Nenhuma deles criança. Tudo bem, foi criança atropelada, mas que tava dentro do carro, nenhuma criança. É uma sociedade mais segura na questão de não ter muita violência, né? Nem no trânsito nem na questão de nada, nada. Não existe nenhuma casa que tem muro ao redor da casa. Então, quando uma pessoa tá falecendo, normalmente, é uma pessoa que você já sabia muito tempo que está falecendo. Você teve um tempo para liberar com sentimento que você tá perdendo uma pessoa.

Por último, agora, foi minha mãe que faleceu em Bergen. Ela tava, não vou falar no asilo, porque é uma questão do governo, né? Na Noruega, ninguém morre na sua casa. Você sempre vai pra um abrigo, mas de super boa qualidade, você pega o seu quarto, você tem seu banheiro como se fosse um hotel. Nós sabíamos, o último ano já estava esperando a morte dela. Os últimos quatro 
dias, sabendo que agora ela tá falecendo. E com muito apoio, assim, na questão de morfina. Pra falar a verdade, a morte foi uma coisa bonita, no final. Não foi aquele choque, não foi aquela coisa, assim, superagressiva. E todo mundo, assim, apoiando muito. Foi numa quinta-feira. Normalmente, na Noruega, pelo menos na nossa comunidade, tem na terça e na sexta, tem sepultamento. Sabendo que, então, ia ficar oito dias para resolver tudo. No início, óbvio, ligando para os irmãos dela, avisando todo mundo, porque quem tava lá quando ela faleceu era nós quatro, filhos dela. Muito legal. Ficamos lá, nesse abrigo, no quarto dela. Quatro dias, dormindo lá, que tava grande, boa qualidade, comida boa. Foi muito, muito legal, foi uma união com os irmãos. Tem várias qualidades, mas onde minha mãe ficou, excelente! Tem muitos médicos, enfermeiras cuidando dela com qualquer tranquilidade. A gente visitando ela todos os dias, mas é o governo que cuida. Esse é o sistema da Noruega. Não, assim, que alguém fica olhando pra você porque não deixa sua mãe na sua casa, porque não é o lugar dela. O lugar é ir nesse abrigo, e a gente visitando. Então, é muito fácil, assim, né? Todo o funeral, na Noruega, é caro, uns dez mil reais. Mas, também, uma velha na Noruega, pelo menos, tem dinheiro no banco. Não é, assim, que a gente tira do nosso bolso. No início, você vai um dia falar com o pastor, porque, na Noruega, todo mundo utiliza essa igreja nossa, a igreja luterana, quando tem um funeral, assim, é do governo, mas é da igreja, ainda é ligado à igreja. Você vai e fala com o pastor, porque, às vezes, o pastor nem conhece a tua mãe. Então, ele quer saber um pouco quem era, pra ele fazer um discurso durante a cerimônia. Outro dia, você vai com o pessoal da funerária, a questão de caixão, toda essa questão, assim. Um dia depois que minha mãe faleceu, a gente, lá, nesse abrigo, tem uma capela, também, e nós fizemos uma coisa pequena lá. Com o pastor que iria, também, fazer o funeral dela dias depois. Então, chamamos todos os nossos filhos, os netos, pra eles vê a avó pela última vez. Achamos um pouco estranho, porque ela era dura, né? Porque tava congelada. Eles colocam num lugar pra ficar mais congelada, pra preservar o corpo, e que eles têm no próprio abrigo. Mas todo mundo falando tchau, e aquela coisa mais íntima da família mesmo, assim. Os netos colocaram rosas dentro do caixão, cada um colocou uma flor dentro do caixão. Só os irmãos, os netos e a gente mesmo fechando a caixa. Eu e meus filhos botamos os parafusos. Acho que é bom pros filhos, também, ver essa questão e ver ela, que, também, é uma coisa morta, mas, mesmo assim, eles vão ver. Beijar o corpo não é comum lá. Pegamos na mão, passamos a mão no rosto dela, mas sem beijo. Todo mundo pegou na mão e tocou no rosto. Essa cerimônia é chamada de Likskue, em norueguês, que significa "olhar o corpo".

Depois ficam uns dias e vem o dia do funeral. É aquela questão que você tem tempo pra planejar, né? Tem o músico, os hinos que a gente utiliza. Não é coincidência, é o que minha mãe gostava. A gente senta junto, os irmãos escolhendo juntos, e tem alguns tipos para o funeral. Foi um momento muito legal, a gente sentou junto, tocou violão, lotou a igreja. Outra coisa que é possível quando você tem uma semana de planejamento. Colocamos anúncio no jornal, comunicando publicamente o falecimento, o dia e o horário do funeral, do sepultamento e da recepção. A publicação no jornal é a família que coloca. É paga, deve ser no máximo cem reais. Todo mundo faz. O festejo da ida dela foi aberto só para os familiares. O festejo é muito comum, principalmente, quando é uma pessoa velha. Quando é uma pessoa mais jovem, é mais sofrimento pra família. Quando é uma pessoa velha, normalmente, é muita comida. Comida gostosa, pão com camarão, com carne, bolos, todos os tipos de café. Nada de bebidas alcoólicas que não é comum na igreja na Noruega, mas todas as outras coisas tem. E, principalmente, pra juntar a família dela, ficar conversando sobre ela. Alguém fala alguma coisa, eu toquei violão, umas músicas que ela gostava. Mas dentro da igreja é mais, assim, contido, aquela coisa mais chique, e muitas flores que a gente sempre coloca. É tradição nossa, cada família manda uma flor e uma bandeira que tem escrito alguma lembrança para ela. E, quando a gente chega no buraco mesmo, a gente joga em cima do caixão e vai junto com ela. O livro de condolências tem mais quando a pessoa é pública, mas, uma pessoa particular, não é comum, não. É comum ter uma foto dela na igreja, perto do caixão, e, também, você faz uma folha com os hinos que vai se cantar e, também, a agenda com a programação. E, às vezes, uma oferta pra uma coisa que ela gostou, ou eles pedem: "Em vez de 
flores, doa dinheiro pra tal,tal,tal.". Se alguém morreu de câncer, é muito comum doar para uma organização que luta contra o câncer. A missa, na Noruega, normalmente, é só no domingo. O dia do funeral depende da comunidade. Como trabalham no domingo, geralmente, os pastores tiram folga na segunda feira. Ela foi sepultada, isso é mais comum com os velhos. Essa questão de cremação é um pouco mais chique, né? É um pouco mais novo. Pra minha mãe, pra nós, foi óbvio que ela tinha que ser sepultada mesmo. Quando é jovem o mais comum é cremação. E, também, porque, quando é jovem, muitas vezes, é câncer. $\mathrm{E}$, às vezes, quando é câncer, eu acho que as pessoas sentem um pouquinho alegria de queimar aquele câncer. Eu ia sentir. Acaba com tudo, né? Vai lá, queima tudo.

Nós somos mais diretos para falar sobre a morte. Para avisar nossa família a gente falou: "Ela morreu.". Talvez, a minha irmã falou: "Ela se foi.". Na Noruega, não tem tantas expressões. Vocês têm mania de dizer: "Ela dormiu.", "Foi levada.". Tem alguns que gostam de explicar para as crianças: "Agora, ela tá dormindo para sempre.", mas é meio comum explicar que ela morreu. Eu, para meus filhos, sem dúvida, disse: "Vovó morreu. E, agora, a gente não sabe onde ela foi.".

A funerária faz a questão de transporte. Quando a gente foi na funerária, depois, a gente só vai ver o caixão é lá, na igreja, mesmo. Tudo, assim, pronto, já com as coisas em cima, todo bonitão, lá, na frente. É uma questão de logística. Eles têm, também, muitas dicas. Na questão de músicas, de músicos. A recepção é organizada por eles. Nós organizamos a da minha mãe na igreja porque a gente tem ligação com a igreja, e ela, também, tinha. No funeral, os homens usam terno, gravata e tudo mais, né? E as mulheres é vestido. Nada de colorido, roupa preta. Pode ser branca também. A roupa folclórica é usada no dia 17 de maio, Dia da Constituição. Completou duzentos anos. É uma festa do povo, não é militar. É usada, também, no Natal. No funeral, não. Nos funerais, a família norueguesa pode chorar. Chora que sai lágrima quando começam a falar coisas positivas do falecido. Isso não é vergonha. Mas não grita: “Oh, meu Deus!". Não tem grito de choro.

Nos cumprimentos, tem aperto de mãos e palavras. Se você conhece a pessoa muito bem, tem abraços e palavras. Beijo, não. A pessoa fala: "Condolências". Às vezes, quando você fala com os filhos, você fala bem do pai, ou da mãe. Por exemplo: "Você teve um pai ótimo.". A pessoa muito íntima só abraça e não fala nada. Se não for íntima, só fala "Condolências.".

No Brasil, é aquele estresse, aquele cansaço. Principalmente, em Tocantins. Aquele mundo de pessoa que vem e fica na sua casa, e você tem que gastar com comida e tudo. Na Noruega, é muito mais tranquilo. A pessoa tem a oportunidade de sofrer em paz.

\section{Informante 10 NO}

Agora, eu trabalho meio expediente, na Igreja Luterana Norueguesa na América do Sul, eu tenho 80 dias que estou viajando na América do Sul. Eu divido em 4 viagens em setembro, dezembro, fevereiro e maio. O resto do ano, eu trabalho aqui na Noruega. Sou responsável pelos noruegueses que moram na América do Sul, sou pastora de todos os noruegueses na América do Sul, fico viajando entre colônias ou grupos. Tenho 45 anos, moro numa ilha que fica a $500 \mathrm{k}$ de Oslo. Morei no Brasil 8 anos, 6 anos em Brasília e 2 em Cabo Frio, onde tinha a minha base. Nem sempre tenho uma igreja onde moro.

Eu não fiz enterros de noruegueses na Igreja Luterana no Brasil, mas celebrei cerimônia antes que o corpo viesse para a Noruega. Em 1995, celebrei o enterro de uma brasileira, descendente de Alemanha, em Brasília. Eu trabalhava na Igreja Evangélica de Confissão Luterana no Brasil, que é frequentada por muitos alemães. Seguimos a liturgia e a cultura dessa igreja. Todas as pessoas eram brasileiras. Eu já sabia que aí o enterro tinha que ser no dia seguinte. Eu estava preparada que as pessoas próximas ainda estavam nessa fase de choque. O caixão tava aberto. Isso pra mim foi muito diferente. Na Noruega, está fechado. Tinha greve naquele lugar. $\mathrm{Na}$ 
hora de descer o caixão, disseram que estavam em greve, e ficamos sem saber o que fazer. Ficamos cantando, cantando, cantando no calor, até, depois de meia hora, chegar um homem para ajudar a descer o caixão. Foi meio, assim, caótico. Na Noruega, se você não quer fazer nada, você paga, e a funerária faz tudo.

Não assisti a funerais de noruegueses aí, mas já fiz várias cerimônias memoriais, e o caixão foi enviado para a Noruega depois. Vou contar o da princesa Ragnhild Alexandra da Noruega, no Rio, numa Igreja Anglicana, há dois anos. Ela morreu aos 82 anos e morava no Rio há 40 ou 50 anos. Tentei fazer uma cerimônia meio brasileira, norueguesa e inglesa. Era uma igreja anglicana, fizemos uma mistura de línguas e culturas. Tentei fazer como na Noruega com a família participando. A família toda ganhou uma vela pequena, colocamos uma coisa de cozinha com areia, e eles colocaram as velas ao lado do caixão. Cantamos os hinos, procuramos uma música que se canta no Brasil, na Noruega e na Inglaterra, cantamos uma estrofe em cada língua. Eu fiz o discurso nas três línguas. Tinha gente dos três países. No final, a família ficou num lado, e todos que participaram passaram pela família e a cumprimentaram. No dia seguinte, o corpo foi enviado para a Noruega. Foi um funeral meio diferente, como ela era irmã do rei. Demorou uma semana antes do enterro. Lá, teve mais três funerais, um no castelo da Noruega, depois o caixão foi para outro lugar em Oslo, onde o pai tinha sido enterrado. Foi uma cerimônia só para a família. Houve 4 funerais, pois teve também um na chegada do corpo no aeroporto.

Após o funeral, no castelo do rei, cem pessoas, amigos e parentes, foram convidadas para uma cerimônia festiva. A maioria estava com roupa preta, mas havia mulheres com roupas típicas da Noruega. Foi uma festa com comida de dedo. Assim, que você fica em pé comendo. Canapé. Não era almoço nem jantar em que as pessoas ficam sentadas à mesa. Houve canapés, bolo, café e discurso. O marido dela falou alguma coisa, o rei (irmão) falou algumas palavras, e alguns amigos também. Tinha flores, e depois a família mais próxima foi pra aquele lugar onde o caixão foi enterrado. E nós outros fomos embora. Tinha flores, não tinha fotografias. E o que achei interessante, que gostei, achei legal que todos podiam participar. No Rio, coloquei tabuleiro com areia no altar da igreja, no Rio, e eles colocaram as velas lá. Minha tia disse que não podia ser assim, ela era uma princesa, tinha que ser uma coisa chique, mas eu não tinha tempo. E, em Oslo, fizeram a mesma coisa com o tabuleiro. Acho que eles copiaram a ideia, achando que era tradição do Brasil que quiseram manter na Noruega. Eles pensaram que tinha que ser assim para acender as velas e colocar ao lado do caixão. Eu não perguntei. Achei engraçado e pensei "vou contar pra minha tia".

A cerimônia, na Noruega, foi bem tradicional. O pastor falou primeiro algumas palavras sobre a princesa, depois, o filho mais velho falou sobre o lado mais pessoal, fizemos leituras da bíblia, o pastor fez um outro discurso mais bíblico depois. Lembro que a princesa já tinha escolhido os mesmo hinos que o pai dela usou no funeral dele. Estava muito ligado com o rei (pai). Foi bonito. Fizemos tipo um desfile em volta do caixão, no tapete do caixão. Isso não é comum num funeral na Noruega. Acho que era porque ela era princesa.

Na Noruega, a pessoa morre numa instituição, num hospital ou numa casa para velhinhos, alguma coisa assim. Os familiares logo ligam pra funerária e eles fazem tudo. Eles colocam a pessoa morta no caixão e limpam, arrumam e colocam o corpo num lugar frio ou gelado. Dois dias depois, só os mais próximos têm uma despedida com a pessoa morta. Isso é arranjado pela funerária. Pode ser uma palavra da bíblia um poema, alguma coisa assim, desenho de filhos, netos, flores, coisas importantes pra pessoa. Eles colocam no caixão. Depois fecham o caixão com parafusos e não abrem mais, a não ser que venha parente de fora e quer se despedir. Há dois anos, era uma regra que o funeral tinha que ser antes de sete dias depois da morte. Agora pode chegar a duas semanas. Normalmente, é de cinco, seis, sete dias. Pra pessoa preparar as coisas, se tem alguém viajando pode esperar. Isso também tem a ver.

Na Noruega, no dia do funeral, geralmente é a família que coloca o caixão na igreja uma hora antes do funeral. O caixão está numa casa gelada. Geralmente, são os filhos e os netos que fazem aquele papel com os hinos, e os netos entregam às pessoas na igreja. Normalmente, aqueles 
que vão para o funeral chegam uma hora antes. O organista toca música enquanto as pessoas estão chegando. No funeral, geralmente tem três hinos. Muitas vezes, tem uma solista que toca músicas diferentes, além das que a comunidade canta. Começamos sempre com um discurso sobre a vida da pessoa. Em geral, eu faço esse discurso, mas pergunto sempre antes se algum familiar ou amigo quer falar alguma coisa, que fica mais pessoal. Isso depende, uma família tem muitas pessoas que querem falar, outras deixam tudo por conta do pastor. Primeiro, o discurso, depois, cantamos, tem três leituras da bíblia e, depois, o discurso que é mais bíblico. Eu procuro relacionar os dois discurso, que o discurso bíblico fica ligado com a pessoa que tá morta, tem a ver com a vida dela ou dele.

Sempre tem bastantes flores em cima do caixão e ao redor, depois do último hino, as pessoas da funerária entregam flores para as pessoas que não vão carregar o caixão. Tem seis pessoas que carregam o caixão, e as outras carregam flores. Saímos fora da igreja. O cemitério, em geral, é ao lado da igreja. Saímos a pé. Botamos o caixão ali, colocamos as flores, baixamos o caixão, cantamos uma música, lemos a bíblia, e, normamente, uma pessoa da família agradece a todos por terem ido. E aí acabou. Às vezes, depois, dizem "Vamos para algum lugar pra nos lembrar da pessoa e vamos comer. Todo mundo está convidado". Outras vezes, não. Isso é o comum, mas depende um pouquinho. Noventa e nove por cento dos funerais são nas igrejas.

Quase sempre vou pra casa da família e pergunto sobre a vida do morto. Se eles preferem, podem ir ao meu escritório, mas prefiro ir à casa deles. Levo de 1 a 2 horas pra que eles me passem uma imagem da pessoa. Fica mais próximo. A gente toma café, vejo fotos. Depois de escrever o discurso, às vezes, eu envio pelo e-mail pra família pra eu ter cem por cento de certeza que eles querem que o discurso vai ser assim. Porque, depois, você não pode acertar o que foi falado no funeral. Gasto bastante tempo.

Normalmente, é a funerária que coloca os anúncios no jornal. A família pode fazer. Uns colocam só depois do funeral, pois querem ter só a família. $\mathrm{Na} 4^{a}$ feira vou ter dois funerais assim. Eles vão colocar o anúncio no jornal só depois do funeral. Mesmo sem ser religiosa, a maioria das pessoas faz o funeral na igreja. Só os que não são membros da igreja e são muito contra podem usar outros lugares. A igreja na Noruega é a igreja do governo. Quase $90 \%$ dos noruegueses são luteranos, pertencem à igreja. Tem muitos que não vão muito a igreja, mas são batizados, pertencem à igreja. A Igreja Luterana não tem missa de $7^{\circ}$ dia, mas após o funeral, na primeira missa, o nome da pessoa é lido, e a comunidade se levanta e faz 1 minuto de silêncio. Só tem funeral $2^{\mathrm{a}}, 4^{\mathrm{a}}$ e $6^{\mathrm{a}}$ feira. As missas são sempre aos domingos.

Expressões suaves para comunicar a morte: ele dormiu, todo mundo entende que se fala de morte, ele já foi, pass the way, ele se foi, ele passou. Jovens falam game over, fim de jogo. No Exército da Salvação: a pessoa foi processada pra glória. Fica difícil de traduzir pro português.

É mais comum agora mostrar sentimentos do que alguns anos atrás. Isso depende de uma família para outra. Antes, eles tomavam remédio pra ficar mais fortes. Na hora de falar alguma coisa sobre mãe, pai, avós, eles choram um pouquinho e recomeçam. Você vê que não é tão fácil pra eles. Isso não era tão comum antes. Talvez o homem tenha mais dificuldade de mostrar lágrimas. $\mathrm{O}$ abraço é bem comum. Homem não abraça homem, mas isso também está acabando. Há 20 anos, era meio difícil, agora é bem comum o abraço. Às vezes, dão a mão e um abraço ao mesmo tempo. Você dá a mão e sente se vai ser legal dar um abraço, ou não. $O$ aperto de mão é a primeira tentativa, o teste. Às vezes, isso fica próximo demais. Beijos não tem. Isso é brasileiro.

Quando os próximos falam alguma coisa sobre a pessoa morta, acho isso bem interessante. Eles falam com o coração, e isso é bem emocionante, pois eles fazem uma coisa que é muito difícil pra eles, mas fazem com amor. Uma coisa muito bonita de ver.

$\mathrm{Na}$ hora de baixar o caixão, às vezes, dói ver o sofrimento dos familiares. É uma coisa bem dramática. Pode haver um choro mais forte. É o momento que os familiares ficam juntos. Isso também me comove. 


\section{Informante 11 BR}

Eu estive em três funerais. Eu acredito que são relativamente similares. Então, o costume é que não existe corpo no funeral. O corpo é tratado de maneira separada por pessoas técnicas, normalmente, logo depois do falecimento. E há uma celebração de vida que ocorre uma semana a dez dias após o falecimento.

Essa celebração de vida, normalmente, ela é uma série de discursos de pessoas falando sobre a pessoa que morreu. Normalmente, ela tem uma duração de uma hora e meia a duas horas. E ela é, normalmente, organizada num hotel, ou num clube, ou num lugar público desse tipo. E, em um dos casos, ela começou numa igreja, que é uma igreja anglicana, com uma espécie de uma missa e depois com uma reunião num clube. E, normalmente, tem um show de fotos, de música, tem uma série de símbolos, celebrando a vida da pessoa que faleceu. Tem amigos, parentes, esposo, às vezes, falando sobre a experiência de viver com aquela pessoa. E, depois dessa celebração, de um show de fotos, desse tipo de coisa, aí, normalmente, tem um coquetel, uma recepção com bastante comida e esse tipo de coisa. Os três funerais que presenciei aqui, aliás, foram quatro, todos eles foram em formato similar. Normalmente, tem um convite para o funeral ou um programa que é impresso. É muito diferente da experiência de funerais no Brasil.

A família, às vezes, vê o corpo, às vezes, não, dependendo da situação. Mas o corpo é retirado do hospital pelo pessoal técnico. Todas as pessoas que eu presenciei foram cremadas. Então, o corpo é retirado do hospital pelo pessoal do crematório e é cremado por eles sem envolvimento de amigos, parentes ou família. Então, o corpo é tratado de uma maneira muito técnica, são profissionais que fazem a disposição do corpo. Num dos casos, o corpo foi doado pra ciência. Foi retirado do hospital pelo pessoal que utiliza o corpo pra fins científicos. Então, o corpo nunca é uma parte da cerimônia. E, mesmo quando a pessoa que faleceu foi cremada, as cinzas não estão presentes na celebração, no ato público. Tem muitas fotografias, o comum é ter fotografias, e ter shows de slides, com muita fotografia, com música, e daí tem as pessoas contando histórias da pessoa que faleceu, ou relembrando uma série de pequenos discurso. E, às vezes, dependendo da situação, é feita até de uma maneira, assim, de contar coisas engraçadas que aconteceram durante a vida da pessoa, ou coisas importantes, ou falar de viagens que a pessoa fez. Essa é a minha experiência, e eles chamam isso de celebração da vida.

A principal diferença para o Brasil era (sic) a distância da morte para a celebração da vida. A distância no tempo. A celebração da vida, em todas as experiências que tive, foi uma coisa muito bonita. Trouxe, realmente, a pessoa presente pela memória, pela memória das pessoas que estavam presentes. Mas não é o caso de chocar, mas é o caso de ser uma coisa muito diferente. As emoções não são mostradas em público da mesma maneira que você vê quando você faz aquela congregação de pessoas assim que a morte ocorreu (sic). Então, uma semana depois, dez dias depois, as pessoas que são mais próximas a que faleceu já tiveram tempo de processar a morte de uma maneira privada e, na maioria das vezes, elas já estão, claro que ainda mostrando sentimento, mas de uma maneira muito mais reservada, muito menos demonstrativa do que o que a gente vê quando o funeral é feito imediatamente após a morte.

Quanto ao tipo de cumprimento, varia bastante, varia muito. Duas das pessoas que eu presenciei o funeral eram amigos meus gays, que o parceiro estava lá. E, aí, havia bastante contato, muito abraço, muito contato físico. Principalmente, do resto da comunidade. E dois funerais que eu presenciei de pessoas de mais idade. Um vizinho meu que morreu aos setenta anos, e um colega da universidade que morreu aos sessenta anos, e, nesses, havia muito menos contato, nem aperto de mão, simplesmente palavras, simplesmente conversa, com muito carinho. A proximidade estava lá, mas a maneira de interação física era muito diferente. Basicamente, o contato eram as palavras. Pelo que eu lembro, não existe uma série de palavras assim como a gente fala no Brasil, meus pêsames, meus sentimentos. A impressão que tenho é que a pessoa faz uma pequena conversa sobre a pessoa que morreu, ou pergunta alguma coisa à pessoa que sobreviveu, que está ali, mas não tem muito de expressar o sentimento pela morte de uma maneira 
formal, com alguns dos amigos. Era mais de as pessoas chegarem e falarem alguma coisa tipo: "Eu lembro quando isso aconteceu.". Alguma coisa, assim, de manifestar a perda, mas não de expressar claramente "Eu sinto muito pela sua perda.", coisa assim.

Você não diz que alguém morreu, você diz que a pessoa "passou". Principalmente, com as pessoas mais próximas. Se fala de perda, no lugar de morte. Se diria que é uma grande perda.

Quando a pessoa não é popular, diz-se "Já vai tarde!". Uma outra é "Ninguém vai sentir falta.", que equivale à expressão em português "Não deixará saudades.".

No Canadá, normalmente tem um livro pro pessoal assinar, um livro de assinaturas, que é muito comum, ou livro em que você pode deixar uma mensagem. E, hoje em dia, tem muito um sistema eletrônico pro pessoal deixar mensagem ou nome, com a ideia de que, como tem muitas pessoas da relação que estão distantes, que é uma maneira delas poderem participar do evento mesmo não estando presente. É uma página na web criada, às vezes, por casas funerárias, com foto da pessoa, uma pequena biografia, uma pequena notícia sobre a morte, e daí tem espaço embaixo para as pessoas poderem assinar, uma espécie de livro de condolências, e também deixarem mensagem. E isso é arquivado, condicionado e proporcionado pra família.

Uma outra coisa muito comum, aqui, é que, quando uma pessoa morre, é comum que se peça doação pra alguma instituição, pra alguma entidade, alguma causa em nome da pessoa que morreu. Normalmente, um convite pra uma celebração de vida vai dizer "No lugar de flores, solicitamos doação para determinada causa.”, pode ser à instituição que combate o câncer. Em, praticamente, todos os funerais, tem esse pedido de doação. As flores são caras. A celebração de vida é uma festa. Em geral, a família escolhe um tema, escolhe o tipo de flores e pede aos convidados que façam uma doação financeira pra uma determinada caridade. É um evento marcado quando a morte ocorre, imediatamente, a família escolhe o dia, marca o evento e reserva o hotel, o clube. Quase sempre em lugar público, e faz o pedido dos coquetéis. Entre a morte e a celebração de vida, não existe nenhum evento organizado. Em algumas famílias, há uma tradição de as pessoas levarem comida pra casa da pessoa que morreu. Os amigos levam a comida, mas não ficam na casa, a ideia é deixar a família sozinha pra processar a morte. Isso vem de uma tradição de longa data quando a família tratava do corpo e não tinha tempo pra cozinhar. Hoje em dia, a família não cuida do corpo, mas a tradição continua. A ideia é de deixar a família sozinha, num grupo muito restrito, pra processar a morte. O pessoal mais chegado pode fazer uma breve visita a casa, levando alimento.

Há uma diferença muito grande no modo de expressar os sentimentos no Brasil e no Canadá. No Brasil, há uma expressão de sofrimento. No Canadá, mostra uma fisionomia que você está composta, não está chorando, como se não estivesse sofrendo. Por aqui, dizem: "Ela está se segurando bem.”. Isso é uma coisa positiva, tem um certo incentivo do grupo social pra que as pessoas não expressem tão abertamente seus sentimentos.

São processos de elaboração de perda muito diferentes. A cultura canadense tem muito da cultura britânica e que é esse processo assim de que você não se expõe, que você se mantém de uma maneira mais reservada. Você é mais privado do que a situação do Brasil, que praticamente não existe delineamentos de separação quando se fala da morte. No Brasil, as pessoas vão imediatamente pra junto da pessoa que perdeu alguém, não vão ter um sentido de que precisam dar espaço pra família, de que a família precisa estar sozinha. É o contrário. O ímpeto do brasileiro é, assim, que alguém está numa situação dessa. É ir pra junto , estar junto e se oferecer pra ajudar de qualquer maneira. No Canadá, a maior diferença é essa reserva, atitude de não interferir, de manter uma certa distância. A maior diferença está no momento da morte. Por exemplo, um dos primeiros casos de um amigo meu. O companheiro dele, a morte ocorreu no hospital junto a um grupo de amigos. Teve um grupo de amigos junto no hospital, quando ele faleceu. O companheiro dele, imediatamente após a morte, foi pra casa e ficou sozinho até o dia seguinte. Pro brasileiro, isso seria um absurdo, e aqui é natural. 
Aqui, nunca participei de um funeral de corpo presente, mas ocorre. Nesse caso, o corpo é colocado numa geladeira, onde fica por uma semana e depois é retirado, vestido, maquiado etc. E, aí. enterrado, e, aí, o corpo está presente, mas nesse caso, em geral, o caixão está fechado.

Os cemitérios são distantes da igreja e são múltiplos congressionais, com exceção do israelita.

\section{Informante 12 BR}

Eu sou pastor há dez anos e meio aqui, no Canadá, eu moro, há seis anos, na cidade de Calgary, província de Alberta. Tenho 51 anos e tenho dois filhos nascidos no Canadá, e minha esposa é brasileira. Sou pastor da Igreja Luterana São Matheus. É uma congregação bilíngue, inglês e alemão. Eu tenho dois grupos aqui, um de imigrantes alemães e outro de canadenses. Eu tenho uma congregação de muitas pessoas idosas. É uma igreja bastante conservadora e tradicional. Quando eu cheguei aqui, eles estavam sem pastor, e havia muita gente, assim, já no estado final da vida deles, e meu primeiro ano aqui, no meu ministério, foi de fazer muitos funerais. Eu acho que, no primeiro ano, eu fiz mais de trinta funerais. O que eu tenho pra relatar é que eu agora estou acostumado com a maneira como os funerais são feitos aqui. Eu tenho observado que aqui não existe o velório como tem no Brasil. Não existe velório, o que existe é um breve espaço de tempo antes de começar a cerimônia, no caso, o culto fúnebre, o funeral. Uma hora, duas horas antes do culto, abre-se o caixão, e as famílias vão lá ficarem juntos naquele tempo antes do culto. Depois, fecha-se o caixão, e se começa, então, a cerimônia. Também, você está entrevistando um pastor luterano. Existem diferenças entre igrejas, como os outros pastores fazem, né? Nós não costumamos usar muito o que chamamos de eologia que é o tributo, que as pessoas vão lá na frente falar da pessoa que faleceu. Nós não costumamos incorporar isso dentro do culto. Nós fazemos isso depois, após a cerimônia, quando há a recepção com comes e bebes com todos os presentes. Aí, a família pode falar. Mas, então, começa-se a cerimônia, e a cerimônia que eu faço leva em torno de cinquenta minutos, mais ou menos. O máximo uma hora quando existem mais músicas e assim por diante. Os funerais são inteiramente feitos nas casas fúnebres mesmo. $\mathrm{O}$ hábito de se fazer funeral nas igrejas tá caindo cada vez mais. Algumas famílias pedem pra fazer na nossa igreja, mas, geralmente, é feito no local mesmo, lá na casa funerária que tem capelas muito bonitas, tem capacidade de sentar muitas pessoas. Então, fica mais prático. A cerimônia, depois de cinquenta minutos, geralmente, o caixão é levado até o carro fúnebre e, aí, no caso, segue-se para o cemitério e lá se faz uma pequena cerimônia, um rito bem curto de... não dura mais que quinze minutos. Devido ao tempo, também, no Canadá, as pessoas não podem ficar muito tempo no frio, né? E lá, no cemitério, então, acontece essa pequena cerimônia, e existem flores. Depois que eu terminei a cerimônia, o diretor da funerária oferece aos familiares a oportunidade de pegar uma flor e levar pra casa. Alguns, às vezes, jogam a flor em cima do caixão enquanto estão descendo o caixão, né? É tudo automatizado. Existe um motorzinho e tudo mais. Isso quando é feito o sepultamento em terra, porque, às vezes, já foi cremado o corpo. Então, se faz no mausoléu, dentro mesmo onde ninguém precisa ficar no frio. A urna é colocada, então, numa espécie de gaveta. O que eu percebi é que as pessoas usam, normalmente, o usual preto, que é o luto ainda, mas isso tem mudado hoje em dia. Às vezes, é uma cor mais sóbria, azul marinho. O que eu percebi, que realmente chamou a atenção entre o Brasil e o Canadá, é a maneira como se portam os familiares da pessoa que faleceu. Tanto no velório, que é bem curtinho em relação ao Brasil, como no culto em si, na cerimônia e, também, no sepultamento. São três momentos. Eu vejo menos emoção do que no Brasil. O canadense é menos emotivo. Não sei se a gente pode chamar de mais frio, não sei se devido ao tempo. O que a gente vê, no Brasil, nos funerais, nos sepultamentos, é, muitas vezes, alguém da família se desespera, a viúva se joga em cima do caixão. Esse tipo de coisa eu nunca vi acontecer aqui. É muito, muito raro. Até mesmo o choro da 
viúva, do viúvo, ou dos filhos é bem contido, controlado. O canadense, ele não mostra muita emoção. Às vezes, a gente vê lágrimas, mas não é aquele pranto desesperado que a gente vê no Brasil. Eu jamais vi isso aqui. É diferente. São duas coisas: a maneira como eles mantêm o luto, como eles controlam as suas emoções, e, também, a questão de se fazer a cerimônia uma semana depois que a pessoa faleceu. O corpo fica sendo cuidado lá, na funerária. Não é como no Brasil que, um, dois dias depois, já é sepultado. Aqui, em média, fica uma semana o corpo, pra família ter tempo de contatar todos os parentes e tudo mais. Depois do sepultamento, há uma recepção. A família mesmo contrata alguém, ou, às vezes, a própria funerária contrata alguém pra trazer os comes e bebes, e a família fica confraternizando lá, inclusive, muito descontraído também. Não é nada desesperador, ou não é nada muito triste depois. A recepção, você vê os familiares todos rindo, olhando as fotos da pessoa que morreu, até mesmo contando piadas, por um bom tempo, e falando coisas interessantes da pessoa que faleceu. Então, é um momento de descontração onde a família pode relaxar. É um fator psicológico importante pra viúva, o viúvo ter aquele momento de relaxar depois que passou o ritual.

Nós não temos um culto de sétimo dia, como a missa da igreja católica. Uma vez por ano, temos um culto, no primeiro domingo de novembro, que nós chamamos de Domingo de Todos os Santos. Na verdade, os santos são aqueles que faleceram na fé em Cristo. Todo cristão é um santo, de acordo com a bíblia, no sentido de que a gente é pecador e santo ao mesmo tempo. Deus nos vê assim. Então, nesse culto, no primeiro domingo de novembro, a gente lembra do nome de todos aqueles que faleceram durante o ano. Nós damos o nome de todos eles durante uma oração lá. Nós lemos o nome de todos os membros da igreja que faleceram, ou daqueles que eu fiz o funeral. Então, é isso, né? Esse é o domingo que a gente lembra todos eles.

Todos esses procedimentos já foram arranjados de antemão pela família, tudo já foi pago antes, normalmente. Então, a funerária faz tudo. A funerária chama a família pruma reunião, e eles cuidam de tudo. Eles cuidam da recepção, da cerimônia, de todos os detalhes. E se a família quer usar um PowerPoint, na hora da recepção, com as fotos, com música, tudo isso eles fazem. Até mesmo na hora do culto, da cerimônia, a funerária providencia um pianista ou uma organista na parte musical.

Na hora do culto, eu dou uma breve biografia da pessoa, mas as pessoas, geralmente, já leram, no jornal, o obituário. Em vez da família falar sobre a pessoa, o pastor é que faz essa parte. Quando nasceu, quando foi batizado, em que ano que casou, e veio pro Canadá. Geralmente, veio de outros países, né? As coisas que a pessoa gostava de fazer. Conhecendo ou não a pessoa falecida, eu sempre chamo a família pra vir pro meu escritório, na igreja, e a gente tem uma reunião. Eu aprendo mais algumas coisas sobre a pessoa, às vezes, eu não conhecia de maneira nenhuma, e também sobre os detalhes como vai ser a cerimônia. Então, essa reunião é muito importante. Ela dura uma hora, uma hora e meia, mais ou menos, com a família. Sempre sou convidado pros comes e bebes e faço questão de estar lá. É uma forma de marcar presença e dizer que a igreja se importa com eles. E, normalmente, o que a gente faz, também, é, após um tempinho, ligar pra família pra saber como eles estão e marcar uma visita, pra ver como está a viúva, o viúvo. Pra dizer que a igreja se preocupa com eles, né? Depois do evento, geralmente, a vida continua normal.

No ritual do nascimento de uma criança, vejo que é muito comum as igrejas e os amigos irem na casa levar comida. Em caso de morte, não vejo muito essa prática.

No culto, tem o livro de assinatura da igreja e o próprio da família, providenciado por ela ou pela casa funerária. $\mathrm{O}$ diretor de funeral, eles tão lá com mais duas recepcionistas para receber as pessoas e me ajudam, também, a distribuir o hinário e o programa do culto. Nós, geralmente, costumamos imprimir o programa, assim, todos sabem o que devem fazer durante o culto, o que esperar e o que responder, né? A gente tenta deixar a projeção do PowerPoint mais pra parte social, mas se a família faz questão, daí, o que a gente faz é um momento em silêncio, ninguém fala, é o PowerPoint com música, não é família falando, só o PowerPoint mesmo. 
Nos comes e bebes nunca tem bebida alcoólica. O canadense é muito cuidadoso com isso. O que tem é chá, café, suco, refrigerante.

As expressões de cumprimentos, em geral, são "Minhas condolências", "Sinto muito", "Meus pêsames". Geralmente, tem o aperto de mão e o abraço, apesar de que o canadense não é nem metade do é o brasileiro, em termos de toque. O canadense não é do toque, mas, na hora do evento do óbito, do funeral, então, existe o abraço. O canadense é bem direto, ele fala mesmo "faleceu". Quando eu anuncio, na igreja, é um pouco diferente, porque a gente usa uma linguagem cristã. A gente fala, assim, "Deus o chamou para a casa", algo assim. Ou, então, "Nós perdemos um irmão na fé, que está agora com o Senhor". E daí, nós oramos. No domingo após a morte, nós oramos por aquela família também. Agora, como luteranos, nós não oramos pelo morto, e sim pela família. Nós agradecemos a Deus pelo morto, mas não oramos por ele. Uma outra coisa que é muito comum e virou moda no Canadá, especialmente, quando as pessoas não são cristãs nem ligadas a nenhuma igreja, não são religiosas, elas não falam num serviço funeral, ou culto, elas falam: "Nós queremos a celebração da vida da pessoa tal.". Elas falam celebração da vida. Então, dependendo da cultura e da formação cultural e étnica da pessoa, o funeral pode ser muito diferente do que eu faço aqui. Eu faço funeral para pessoas ligadas à igreja luterana, que, geralmente, é canadense ou descendente de alemães. Os filipinos, por exemplo, eles fazem uma grande festa. Uma grande festa quando falece alguém, mas isso não é minha experiência. A maioria dos filipinos são católicos e, ainda assim, na cultura deles, eles fazem uma grande festa e celebram muito, porque a pessoa falecida está com o senhor. É muito mais do que a recepção que eu tenho com meu pessoal. Eles fazem uma grande festa, provavelmente, na casa funerária.

Existe muito respeito com relação à morte aqui. Não imagino um canadense usando expressões grosseiras em relação à morte. Eles não brincam com a questão de morte. $\mathrm{O}$ canadense é uma pessoa muito ética e muito respeitador.

O momento de maior emoção, para algumas pessoas, é a mensagem que eu dou, pra outras pessoas, é quando fecha o caixão, depois da visualização, aqui chama visualização, o que, na verdade, é o velório. Significa que eles não vão mais ver. Mas o momento mais emocionante é quando desce o caixão na terra.

Quando falece alguém, imediatamente, o corpo é levado pra funerária e só vai aparecer no dia da cerimônia, quando eles prepararam o corpo. A visualização, às vezes, acontece uma noite antes do culto, mas, geralmente, ocorre umas duas horas antes do culto, do funeral. Essa visualização é feita numa outra sala e é aberta ao público. Quando começa o culto, nós temos uma espécie de procissão. Vai o pastor na frente, e daí, segue o caixão, e daí, os familiares. Às vezes, os familiares colocam objetos pessoais dentro do caixão, mas não é muito comum. Em caso de cremação, que a urna vai pruma gaveta onde a porta é de vidro, é lacrado o vidro, não se abre mais, mas fica exposto. Lá sim, eles colocam objetos pessoais, porque é como se fosse uma prateleira, uma cristaleira, assim, né?

A funerária arranja as flores, e, no final da cerimônia, a família enlutada leva as flores pra casa, ou, então, doa pra igreja que oficiou a cerimônia. Quando a pessoa quer uma coisa só pequena, da família mesmo, ela não anuncia a morte no jornal, só convida o pastor dela. Normalmente, quando a família publica o óbito no jornal, ela sempre sugere uma doação para uma instituição filantrópica. Até mesmo, no programa que eu imprimo da igreja, tem atrás assim “ Doações podem ser feitas para tal organização". Às vezes, a família acaba até escolhendo a igreja como uma das beneficiadas. Normalmente, é uma instituição de caridade. Quando você vai no web site do jornal da cidade, e ali você encontra o obituário, você pode deixar mensagens pra família enlutada. Você deixa mensagens lá, e a família agradece no próprio site, lá.

Quando o funeral é feito na igreja, tem velas no funeral, porque nós sempre temos velas no altar, como na igreja católica, ortodoxa e anglicana. Quando é feito na funerária, não tem velas nem crucifixos porque ela é geral pra todas as religiões. A capela é bonita, mas é uma coisa geral, não tem temas cristãos. Aqui, as casas funerárias são um pouco longe dos cemitérios, os carros vão bem devagar seguindo o carro fúnebre numa procissão. Mas, uma das casas funerárias mais 
populares aqui de Calgary, fica bem em frente ao cemitério. Antigamente, as igrejas ficavam próximas ao cemitério. Na zona rural, você vê isso, mas não aqui mais, na cidade. Na zona urbana, são cemitérios do município mesmo, mas, assim, no interior, você vê igrejinhas do lado do cemitério, como no Brasil também. O cemitério, aqui, tem uma parte só de gramado e outra de concreto. É dividido em várias secções. Tem seção só dos orientais, só dos judeus, por exemplo. Eles não usam a cruz, e tem os campos que são só flores. É muito grande, é um parque muito bonito, e as pessoas vão lá passear porque é um parque muito lindo, arborizado.

\section{Informante 13 BR}

Hoje sou poeta, publico algumas coisas, escrevo. Moro aqui, em Edmonton, há 25 anos. O primeiro enterro que fui aqui não teve nenhum defunto. Foi só uma cerimônia, foi de um professor da universidade. A primeira coisa que achei foi que a viúva foi com um tailler vermelho pro memorial service. Cada um falava alguma coisa sobre o professor. Quem foi ele, não houve... Foi mais como se fosse uma cerimônia acadêmica, falando sobre a pessoa. E, aí, eu não entendi nada, mas foi meu primeiro encontro com, depois que você morre, o que acontece aqui. Aí, depois teve como se fosse uma festa que foi como um coquetel onde as pessoas conversam, brincam, riem, celebram. Acho sim que tem que celebrar a vida mesmo, mas me chocou um pouco porque, pra mim, aquilo não foi um funeral que eu tava acostumada como brasileira, aí, né? Que você tem o caixão com a pessoa, e todos os familiares e amigos em volta, e todo mundo se confraternizando e desejando que as pessoas passem por esse momento com conforto das pessoas que estão ali em volta. Então, mas não senti esse conforto, foi mais um encontro social do que realmente um encontro pra mesmo celebrar a morte da pessoa.

Eu fiz um pouco diferente do meu marido. Exatamente, porque eu sabia, eu fiz no Fact Club , fiz tudo bonito, memorial service, mas eu fiz uma cerimônia de uma despedida, celebrando a vida dele. Eu não sinto que haja uma despedida. Eu senti, assim, mais frio. As pessoas, aqui, é diferente, é diferente. A mãe de uma amiga minha faleceu no dia 11, e o funeral só vai ser na sexta feira, quinze dias depois. Eles demoram... Eles chamam o funeral de memorial service. É mais um serviço de memória. Chamam funeral, às vezes, mas não é um funeral como chamamos aí no Brasil. A gente vai pra homenagear a pessoa que se foi. Eles tratam, assim, bem calmo. A gente se descabela um pouco mais quando está perdendo uma pessoa que a gente ama. Então, a separação é bem doída porque a gente tem uma coisa como brasileiro, que eles não têm aqui, que é a bendita saudade, né? A gente sente saudade. Saudade das coisas boas. Então, se aquela pessoa que tá morrendo... Minha mãe, quando faleceu, é uma pessoa que me deu a vida, marcou a minha vida, é doído. Então, eu escrevi uma carta enorme. Minha irmã leu e botou no corpo dela, foi com ela no caixão. Aquela coisa toda. Porque aqui, também, a gente não tem muito funeral de enterro, a não ser que sejam católicos, o que a maioria aqui não é. É mais anglicano, ou não tem religião nenhuma. O meu marido era ateu. Então, os corpos normalmente são cremados. O que não é aí no Brasil. O que senti mais quando o Lauren estava morrendo foi eu não poder botar nem uma vela ali, do lado dele, porque a gente tem esse simbolismo da luz da vela pra guiá-lo na passagem entre a vida terrena e o espírito que vai se desencarnando. Naquele momento, então, eu não pude botar. Ele tava no hospital. O que eu consegui fazer foi... que eles deixam a gente mais ou menos privado, aí, um dos filhos do meu marido estava lá, e eu disse "Eu quero música, traz alguma coisa que eu quero botar música pra ele poder ficar sereno, pra não fazer a passagem sentido dor ou sentindo que tá perdido". Até o final, eu fiquei conversando com ele, pra ele não ter medo pra passar, mas eu senti falta de acender uma vela.

Quando a gente tá aí, no Brasil, a gente tem uma casa própria para fazer o funeral, pra preparar o corpo. A gente tem isso aqui também, inclusive, você não pode fazer nada aqui no Canadá. É a funerária que toma as providências todas. Quando ele morreu, eu fiquei perdida, não 
sabia o que fazer. Aí, eles disseram para eu procurar uma funerária. Eles colocam o corpo numa caixa que vai pra geladeira. Eu nem vi fazer isso. Eu vim embora e larguei o corpo lá, no hospital. No dia seguinte, eu fiquei procurando que funerária eu ia escolher. Eles, então, têm os pacotes todos e perguntam se você quer enterrar, ou cremar. Eles têm todos os tipos de caixão. Se vai cremar, eles têm todos os tipos de urna. Têm desde a simples que é uma caixa de papelão, ou botam, numa jarra bonita, as cinzas da pessoa. Depois, então, eles disseram para eu levar a roupa pra ele. Quando meu marido morreu, eu não o vi mais, eu não vi mais o corpo dele porque, aqui, eles fazem das duas coisas. Ou eles preparam o memorial service que eles chamam. Eles têm os salões e botam aquelas músicas fúnebres, e as pessoas... Então, eles preparam o corpo, maqueiam o corpo, fazem tudo muito bonito. E, então, os familiares, amigos vêm, olham como se tivesse olhando uma obra de arte, ou como estivessem visitando um museu. Você vai lá, olha, se quiser olhar, né? Tomam drinques e conversam e, aí, depois, eles enterram, ou então vai pro crematório. No meu caso, eu não tive isso porque o Lauren sempre disse que queria ser cremado. Então, eles perguntaram se eu queria um memorial service, que, aí, prepara o corpo pra todo mundo ver. Quer dizer, exposição do corpo. Eu disse não porque não tem sentido. As pessoas que conheceram o Lauren vão ficar com a lembrança dele do jeito que foi. O corpo é uma casca, não tem nada. Então, por causa disso, eu não vi mais o corpo dele, eles selam o caixão. Então, quando fui pra lá, sete dias depois... Então, quando eu cheguei lá, a minha filha e a filha dele, só nós três, eles carregam esse caixão até o crematório, a gente foi acompanhando. Eu disse algumas palavras, e a filha dele também. Aí, entra no forno, e, aí, eu apertei o botão com a filha dele, e acabou. E, aí, a gente veio embora. E, aí, cinco dias depois, eles me ligaram que eu podia pegar as cinzas dele.

E os filhos dele, como moravam todos longe, ele morreu no dia $1^{\circ}$ de julho, somente, no dia 17 de agosto, eu pude fazer uma celebração da vida dele. A gente chama aqui memorial service. E, como ele tinha background escocês, eu contratei uma pessoa que tocasse aquela gaita de fole, vestida de escocês. Aí, a família entra. Eu chamei a família toda, escolhi quem é que ia falar sobre o Lauren, o filho dele que era mais ligado a ele. Eu escrevi uma poesia que falei por último, a filha também quis falar, e mais alguma pessoa, algum estudante dele que quisesse falar. Foi tudo mesmo como se fosse um coquetel. Foi tudo servido. Mesas de comidas com coquetel, bebidas... E celebramos a vida dele. Minhas amigas prepararam um powerpoint com as fotos dele e da família, todo mundo junto, com a música Garota de Ipanema. Ele adorava o Rio, adorava o Brasil (...). É tudo muito diferente, é muito alegre. Não tem ninguém chorando. Você não vê choro. Eu é que estava devastada. Acho que nossa influência portuguesa deixa a gente, assim, com aquele aperto no coração, e a gente não controla as lágrimas.

\section{Informante 14 BR}

Tenho 39 anos, estou no Canadá, Edmonton, há 5 anos e trabalho na área de construção. Aqui é muito diferente, é uma coisa que não existe no Brasil. Lido com renovação de casas e de comércio. Faço de tudo. Aqui não é com tijolos, concreto. Aqui, o material é bem mais light. A mulherada até pode trabalhar com construção.

Em Goiânia, o funeral é muito histérico. As pessoas gritam, choram gritando. A emoção é muito mais forte, entende? Principalmente, na chegada do corpo, na saída do corpo, no sepultamento do corpo, é muita histeria. Eu uso a palavra histeria no sentido de que o pessoal expressa os sentimentos de uma forma muito forte e muito audível. É muito emocional, é muito tocante, com certeza. Mas eu não gosto, nunca gostei de ir, pelo fato de que as pessoas têm que ficar sentadas, e o corpo fica ali exposto durante um dia inteiro, uma noite inteira, e as pessoas ali velando um cadáver. Às vezes, tem uma cerimônia, um pastor ou um padre. Eu acho que o mais interessante desse ritual, no Brasil, é que até mesmo quem não conhece o morto vai. Assim, se tem um funeral ali, e o pessoal tá passando, "Ai, o que aconteceu, aí? Nossa, fulano sofreu um 
acidente? Foi morte matada, ou morte morrida?”. A pessoa já entra e já se solidariza com a família do morto, com as pessoas que estiverem ali e acontece aquela aglomeração de gente até desconhecida, ou amigos do amigo, do amigo, do amigo que vem. Os funerais, em Goiânia, nas áreas mais pobres do país, geralmente, é na casa da pessoa falecida, ou da mãe do falecido. Às vezes, acontece de a igreja onde a pessoa frequentava ceder o espaço dentro do templo pra ser o velório. Se a família tem mais dinheiro, é na capela do próprio cemitério. Geralmente, é na casa da pessoa, ou da família. Tem flores, coroas. Geralmente, as pessoas vão à floricultura e solicitam a entrega de uma coroa com dedicatória, alguma coisa, assim. Geralmente, tem flores, também, cobrindo o corpo. $\mathrm{O}$ caixão fica aberto, tem velas que queimam à noite inteira, mas na família protestante, não tem velas nem o símbolo católico no funeral. Se for uma morte não programada, geralmente, a família se junta pra fazer o funeral. Em Goiás, a família manda fazer um santinho e distribui para as pessoas. Hoje, geralmente, é um profile da pessoa falecida. Minha vó fazia coleção de cartõezinhos de defuntos. Era uma coisa muito macabra. No funeral de nós, protestantes, o pastor, dando esperança pros familiares, diz que a pessoa vai ficar bem, no paraíso. Depois, cada um vai pra casa, e acabou ali. Não se fala mais nisso. Não tem Missa de Sétimo Dia como o católico. O caixão, geralmente, se o corpo estiver perfeito, fica aberto, mas, se estiver desfigurado, o caixão fica fechado. As flores são colocadas dentro do caixão, cobrindo o corpo. Só as mãos e o rosto ficam de fora. As pessoas da família beijam as mãos e o rosto do falecido. As mais chegadas ficam sentadas ao lado do caixão e, às vezes, beijam e abraçam o corpo. Isso é normal, né? Em Goiânia, as pessoas vão com qualquer tipo de roupa. Conversam muito e gesticulam. E, aí, as pessoas chegam e falam Meus sentimentos, ele era uma pessoa muito legal. Não tem uma etiqueta.

A notícia de morte é dada indiretamente para as pessoas mais chegadas. Geralmente, a pessoa chega e fala assim: Aconteceu algo não muito bom com seu ente querido. Sofreu um acidente, não suportou e faleceu. Usam também eufemismos: Infelizmente ele não resistiu mais à doença, Fulano não está mais entre nós. Existem as expressões grosseiras como Fulano abotoou o paletó - essa é a clássica -, Fulano juntou as botas, Fulano capotou, Aquele, lá, foi pros quintos dos infernos. Pra uma pessoa muito boa diz-se: Poxa vida, tanta gente ruim lá fora que podia ter ido no lugar. Pra pessoa ruim, Demorô, tipo assim: tava passando da hora dele desencarnar. Geralmente, em funerais, a gente é bem afetiva, dá um abraço, oferece o ombro praquela pessoa chorar, escuta o que a pessoa quer dizer, se a pessoa quer desabafar. Tem bastante contato físico. Bastante contato físico mesmo.

No Canadá, primeiro que, se você não for íntimo da pessoa, ou muito próximo do ente querido do falecido, você nem é convidado. As pessoas estranhas não vão nos funerais. Tem anúncio no jornal. É pago, as pessoas têm que pagar pra anunciar. O segundo ponto é que o funeral não é imediato à morte. Aqui, é de acordo com o agendamento da família, da funerária, da preparação do funeral. A pessoa pode morrer num sábado e ser enterrada no outro sábado. Já vi até um mês depois. Em fevereiro, aconteceu um caso desse. Uma menina de 26 anos se suicidou, e ela não tinha nada preparado. Até serem feitas as investigações pra saber se foi suicídio ou assassinato, até a família fazer a lista de convidados, escolher cores de flores, tipo de recepção etc, foi quase um mês. Essa é a parte chocante que eu acho, o tempo. No dia do funeral, tem toda uma etiqueta. Não é bem visto roupas claras, decotadas, curtas, no funeral. Geralmente, todo mundo se veste de roupa escura, pode ser o calor que for, pode ser o frio que for. O pessoal vem com cartões, que é chamado de simpatia, com coisas escritas de condolência. Geralmente, eles escolhem um lugar de acordo com o número de convidados porque, depois do sepultamento, tem uma recepção. Você chega lá, na capela, dentro do cemitério, na entrada, tem um livro de assinatura. O funeral é por algumas horas. Aqui não tem funeral na igreja, tudo é feito num lugar próprio, é tudo separado, muito bem organizado. Quando você chega, tem uma pessoa da funerária de preto, formalmente, vestida pra receber os convidados e levar pra onde é o local, e a minha amiga tava na porta esperando pelos convidados. Aí, a gente chega, entrega o cartão, aperta a mão. Como ela é portuguesa, houve abraço. Mas geralmente, é só aperto de mão mesmo, Minhas condolências, só. 
Então, ela me disse: "Se você quiser ver o corpo, é dentro daquela salinha". Tinha um lugar pra gente ficar em pé mesmo, o corpo estava numa salinha à parte, com o caixão parcialmente aberto. Só a parte de cima aberta. Eu não vi flores dentro do caixão, tinha um pano muito bonito, rendas, né? Ela era católica, e tinha vela do lado. Ver o corpo é opcional. Quem quiser, entra no quartinho. Aqui, não falam muitas expressões de cumprimentos. Geralmente, é um cartão de condolência e uma mensagem de simpatia.

Quando viram que todos os convidados tinha chegado, aí, então, tinha outra portinha que deu pra outra capela onde todo mundo veio e se sentou, e o padre estava lá. Colocaram o caixão numa espécie de coisa que tem rodinhas, pra carregar o caixão, então, já totalmente fechado. Ninguém carregou o caixão. O caixão foi posicionado ali, na frente. Aí, o padre fez uma cerimônia, falou umas palavras tocou uma música, muito bonita, e, aí, seguimos pra o enterro. A capela é dentro do cemitério. Aí, uma coisa que eu achei muito interessante, então, todo mundo se levantou, e o caixão saiu. Tinha um carro preto esperando o caixão, e os parentes do defunto. Eles têm uma limousine pra levar eles até o local do sepultamento. Tudo arranjado dentro do pacote que a família faz. Bem organizado. A família toda, eles vão na limousine. Como era inverno, todo mundo entrou dentro de seus carros. Os carros entram dentro do cemitério. A gente acompanhou o cortejo. Tava muito frio. O pessoal da funerária estacionou, aí, os homens da família foram, pegaram o caixão e colocaram lá onde seria uma plataforma, a plataforma que desce o caixão. Eu gostaria de destacar que, em nenhum momento, teve choradeira, gritaria, histeria e falando coisas, assim, chorando. Vi lágrimas na minha amiga, filha da falecida, né? Mas gritaria, histeria não. Não vi lágrimas no resto da família, não. O padre faz o pronunciamento básico, na hora do funeral, "as cinzas voltam pro pó". Não lembro direito, são palavras da Bíblia. Aí, as pessoas jogam flores. Todos que tavam no funeral foram pro enterro. $\mathrm{O}$ corpo foi enterrado. Depois que o corpo vai descendo, ali, devagarzinho, aí, as pessoas jogam flores, e a gente não fica lá olhando, vendo jogar terra ou tampá, nada. Desceu ali, acabou. O pessoal entrou dentro dos carros e voltou pro local da recepção.

No mesmo prédio, já era outra sala. Todo mundo já entrou ali e, aí, o ambiente já tava, totalmente, diferente. Dentro do cemitério tem tipo um complexo. E, aí, na área de recepção, já tem mesas com cadeiras e um pequeno enfeitezinho, tem buffet com bebidas que falam de refrescos, tem o cardápio que é escolhido pela família. Depende de quanto a família vai gastar, do número de convidados. É como se fosse uma recepção mesmo, de casamento. E, aí, o pessoal se senta, come e toma um refrescozinho. Aí, a pessoa que tá recebendo os convidados vai às mesas, agradece e conversa, fala alguma coisa da pessoa que faleceu. Todo mundo come. Ali, ninguém chora, o pessoal já dá um sorrisozinho. Tem as pessoas servindo, organizando as coisas, repondo, muito bem vestidas, muito discretas. Tinha café, suco, tal. Nesse, não havia bebida alcoólica, mas já ouvi falar que tem. Em alguns, servem almoço. Ah, antes da recepção, na capela, houve projeção de fotos, tinha uma foto também na entrada. E o neto mais velho falou algumas coisas sobre ela, leu um papelzinho. Na recepção, o pessoal fala só das coisas alegres da vida da pessoa que faleceu, tenta lembrar mais das coisas boas, da felicidade, não da tristeza da perda. Também, falam que a pessoa está melhor agora, ela foi pra um lugar melhor. Terminada a recepção, o pessoal se despede e cada um vai pra sua casa. Creio que só as pessoas bem mais próximas tocam o corpo. Eu não vi. Teve cumprimento só com abraço, sem palavras, mas só entre pessoas bem íntimas. Aqui, é muito mais distante, geralmente, um cartão de condolência, uma mensagem de simpatia. No Brasil, é mais contato físico e expressões verbais.

Em geral, a família coloca anúncio da morte no jornal. É uma coisa normal, colocar no anúncio: "Em vez de mandar flores, fazer uma doação pra instituição do câncer, ou da criança". No meu trabalho, o dono da empresa perdeu a mãe, também. Eu não fui convidada pro funeral, porque eu não tinha contato nenhum, né? Mas, depois, ele anunciou pra todo mundo que tava recebendo doação pro hospital do câncer, em nome da mãe.

Dependendo do pacote, há desde convites formais impressos até o último momento da recepção, né? Tudo muito organizado pela funerária. 
As coisas estão mudando em Goiânia. Já tá começando a ficar, assim, um pouco mais organizado. Já tem alguns serviços funerários pras famílias que têm mais dinheiro. A tendência é melhorar, né?

Tem cemitério, no Canadá, que tem uma área planejada, um local para a recepção dos convidados com salas separadas. Uma sala fechada com acesso por uma porta onde o corpo fica no caixão, e quem quiser velar ali, então, o caixão é aberto, e quem escolher entrar lá e olhar... quem não quer ver não entra na sala e fica em outra sala comum. Dali, as pessoas são encaminhadas para a capela por um corredor de acesso e, na capela, o caixão foi trazido fechado com flores em cima. Depois da liturgia, os homens da família, com a ajuda de funcionários muito bem vestidos de terno e gravata, levaram o caixão com o corpo pra o carro fúnebre. E todas as pessoas acompanharam o cortejo, em seus carros, até o local do enterro. Tudo isso dentro do cemitério.

\section{Informante 15 BR}

Tenho 49 anos, sou gerente de uma empresa de energia elétrica e gás, moro no Canadá há 13 anos, na província de Alberta. Nesses 13 anos já fui a dois funerais, e minha mulher, também, já foi a dois funerais. Mas eu já tive contato com outras pessoas que faleceram ou parentes de outras pessoas que faleceram, mas eu não cheguei a ir pessoalmente no velório. As maiores diferenças, eu acho que são relacionadas ao fato. Há dois outros fatos: (i) que o Canadá é um país de imigrantes, e (ii) mesmo o canadense, é muito raro você encontrar um canadense que mora aonde nasceu, ou mora onde o resto da família está. Então, isso faz com que as pessoas estejam distantes quando uma pessoa falece. Então, o que acontece lá é o seguinte, aqui, no Brasil, a pessoa morreu, em 24 horas a pessoa está enterrada, menos até, se for uma pessoa que morreu de uma doença conhecida, ou morreu num hospital. A pessoa morre de manhã, de tarde, já está enterrando. Lá não é assim. Eles tomam o tempo que é pra dar a oportunidade das pessoas, os amigos e parentes que moram longe chegarem no funeral. Então, é muito comum, lá, as pessoas falecerem hoje e o funeral ser daqui a uma semana, daqui a dez dias; depende um pouco. Uma coisa é a seguinte, eu já vi duas situações acontecerem, uma é como eles preservam o corpo até que todo mundo chegue e o funeral aconteça dez dias depois, mas eu também já fui a funeral onde eles cremaram a pessoa em dois dias, em uma cerimonia só para as pessoas mais íntimas, e, aí, eles fazem o serviço funeral dez dias depois pros parentes e amigos e tal. Então, eu já vi essas duas situações acontecerem. Eu acho que a segunda é a mais comum, onde realmente a pessoa faleceu hoje, dois dias depois, eles fazem a cremação e, aí, eles fazem um serviço pros amigos e parentes que moram longe uns dez dias depois. Inclusive, nesse serviço, eles tinham a urna já com as cinzas da senhora. Lá, teve um serviço religioso, música, e tal. Outras diferenças são que, aqui, quando a pessoa morre o velório normalmente é no cemitério e a pessoa é cremada ou enterrada logo a seguir. Lá, o velório acontece numa casa funerária, é muito interessante que tem umas mais baratas e mais caras, essas casas são feitas pra isso. Então, elas têm uma área grande onde ficam o corpo ou as cinzas, dependendo da situação. É como se fosse uma igreja, então, tem o púlpito lá pra pessoa que vai fazer a cerimônia religiosa, o banco pras pessoas assistirem, mas tem outros ambientes nessa mesma casa funerária. Então, por exemplo, normalmente, no hall de entrada, tem um livro onde você coloca a mensagem pra família. Você assina um livro como se fosse um livro de presença. Normalmente, eles têm uma área onde ficam passando fotos ou vídeos da pessoa que faleceu, tem umas salas mais íntimas com sofás, onde você pode ter uma conversa com os familiares do falecido e algumas dessas casas, inclusive, oferece quartos para as pessoas que vêm de longe, como se fosse um hotel. Eu já vi essas casas lá, mas são um pouco mais sofisticadas, mas, então, assim é um ambiente diferente. Um velório desse, não num cemitério, não numa igreja, são nessas casas funerárias onde eles têm toda essa estrutura. Outra coisa também diferente e estranhei na primeira vez que eu fui num velório lá, é que tem muita comida, servem muita 
comida, chá, chocolate, café, doces, e a família fica insistindo para todo mundo comer. Então, eu perguntei sobre esse hábito e consegui duas explicações: (i) é o sentido de celebrar a vida da pessoa e não a morte, todo foco do velório, todo foco da cerimônia, não é sobre a morte da pessoa, é sobre a vida. Normalmente, parentes falam sobre a pessoa, contam fatos e histórias da vida da pessoa. O pastor, padre, quem celebra lá a cerimônia, ele faz a mesma coisa, fala da pessoa da vida da pessoa, não fala daquele momento que a pessoa está ali morta, entendeu? Eles querem dar a ênfase à vida. Então, a parte da comida é como se fosse uma celebração. Então, é realmente uma festa com comida bebida, eu nunca vi bebida alcoólica não, mas chá, café, refrigerante, essas coisas e comida. Eles querem, realmente, celebrar a vida daquela pessoa. E a segunda explicação, é que é uma coisa comum lá, por exemplo, morreu uma pessoa da sua família, daqui a pouco seus amigos começam a chegar na sua casa com comida, vizinhos começam a chegar com comida. Eles falam que, quando uma pessoa está numa situação dessa, perdeu um parente e tal, você não está com cabeça pra cozinhar, você não está com cabeça pra fazer nada em casa, e lá como é muito raro a pessoa ter empregada, os vizinhos e os amigos percebem isso e falam, pô o Marcelo vai estar lá com a cabeça cheia, eu vou levar comida que é menos uma coisa pra pensar. E, aí, o que acontece? Como vai chegando gente na casa da pessoa, daqui a pouco você tem uma variedade enorme de comida que as pessoas trouxeram pra ajudar. Então, é bem diferente. Realmente, eu, por exemplo, aqui, no Brasil, nunca fui num velório que tivesse comida e bebida, mas lá todos, todos têm. São essas as principais diferenças.

Esse do vizinho e dos amigos, as pessoas até ficam ali pra saber se precisam de mais alguma coisa. Já ouvi falar nessas histórias também, as pessoas que têm fillho, né, aí, vai lá a tia e fala "Eu vou levar o fulaninho pra dormir na minha casa". Aí, dá um descanso pra mãe e pro pai. Então, as pessoas levam comida pra ajudar porque sabem que a família vai estar focada no funeral, no velório, ou, então, não vai estar nem com cabeça para pensar nisso, e as pessoas ficam. Agora, na casa funerária, lá é um serviço, é um serviço que a casa oferece. Eu fui a um velório agora, em fevereiro, e teve a cerimônia, e, depois, falaram "Vamos passar pro salão". Nossa, mas era muita, muita comida, e a família ficava "Vamos, vamos comer". Então, é o sentido da celebração da vida. Mas, antes do velório, as pessoas levam comida para te ajudar. Isso é uma coisa que também acontece lá, as pessoas irem pra casa. Aqui, isso também acontece, o caso de uma amiga sua perder o pai ou a mãe, as pessoas abrem a casa se oferecem de novo pra ficar com os filhos, se oferecem pra cozinhar, se oferecem pra ajudar. As maiores diferenças são o tempo entre o falecimento e o velório, o fato de ser em uma casa funerária e não num cemitério, o fato de ter a festa, a celebração, a comida e a bebida. Essas são as maiores diferenças que eu vejo em relação ao Brasil. Uma coisa que a gente tem que pensar é que a maioria da população de lá não é católica, a maioria da população de lá é protestante, então, os dois velórios que eu fui, é a mesma coisa que a Paula foi, era sempre um pastor. E é muito interessante porque ele leu uma passagem da Bíblia, mas a ênfase é toda na vida da pessoa e não na morte da pessoa, ninguém fala na causa da morte da pessoa, nada disso. Aí, tem as pessoas mais próximas, os filhos. Esse que eu fui era de uma senhora, e cada filho dela leu, como um discurso, relembrando fatos da infância. O filho mais velho contou a história da mãe, da cidade onde ela nasceu, o trabalho que ela teve, e foi isso. Outra coisa, assim, que é interessante lá e que eu agora estou pensando como diferença, é que as pessoas vão super bem arrumadas, a maioria dos homens está de terno. Aqui, nos velório em que eu fui, não tinha essa formalidade; lá, até porque acho que por ser uma casa funerária, não sei, estava todo mundo muito bem-arrumado. Então, é assim outra diferença visual. Nos velórios que fui aqui, no Brasil, as pessoas estavam de roupa comum. O tempo entre a morte e o funeral também dá a oportunidade da preparação tanto para a família quanto para os convidados. Talvez seja por isso que as pessoas vão um pouco mais bem-arrumadas, tiveram tempo de se programar, já sabem com antecedência a hora, enquanto aqui, no Brasil, o que acontece no espaço/tempo de 24 horas, normalmente, é de correria. As pessoas vão, em meio a uma coisa e outra, sai do trabalho rápido, passa no velório. Lá existe uma preparação maior em função deles terem tempo, deles programarem aquela data. Tem as flores também. Em um velório que eu fui tinha coroas de flores, 
no outro que eu fui, a família pedia, no convite, que as pessoas, em vez de flores, as pessoas doassem o dinheiro para fundação de Alzheimer. Essa senhora morreu em decorrência de Alzheimer, então, no convite do funeral, a família pedia que o que você fosse gastar em flores, na verdade, você doasse para fundação de Alzheimer. Mas essa foi a senhora que falei, já tinha sido cremada. Mas, no primeiro que eu fui, tinha coroas de flores, tinha buquês, mas o caixão tava fechado, provavelmente, dentro do caixão, não tinha nada. Lá eles colocam anúncio da morte no jornal, mas acho que não é todo mundo. Olha, o jornal lá tem uma sessão de obituário. Pelo número de anúncios que tem na sessão, eu acho que não é todo mundo que coloca, mas é uma forma das pessoas ficarem sabendo. Os dois velórios que eu fui, um deles tinha anúncio no jornal, mas eles colocaram um dia ou dois antes da cerimônia. Mas eu fiquei sabendo da cerimônia, é claro, porque a gente trabalha, a mãe do meu chefe faleceu, a gente sabia, dentro do escritório, a data e o horário. Mas existe dentro do jornal uma sessão de obituário, uma sessão pequena, e eu acho que não é todo mundo que coloca, tendo em vista o número pequeno de anúncio comparado ao número da população. Existe um convite formal e às vezes um convite com a programação do que vai acontecer. Você recebe o convite formal, com dia e a hora, e, aí, nesse convite, também traz a agenda da cerimônia: tal hora, vai ser o pastor falando, tal, a família. Traz toda a programação. Inclusive, nesse que eu fui, dessa senhora, na parte de trás, tem todas as músicas que eles tocaram. Ah, outra coisa interessante, nesse funeral, é que a senhora programou tudo antes de morrer, dez ou quinze anos antes dela morrer, ela pagou pelo funeral, ela reservou a casa funerária, pagou, ela escolheu as músicas, ela escolheu a sepultura, ela programou esse funeral. Lá existe, inclusive, acho que aqui também existe, empresas que você paga o funeral à prestação. Ela programou todo funeral, no programa, é claro, na capa, tinha dia e a hora, uma fotografia da senhora, tinha uma citação bíblica. Abrindo, você tinha o programa, o que e quem ia falar a cada hora, o nome do pastor. Na parte de trás, tinha a relação de todas as músicas que foram tocadas durante a cerimônia e que foram escolhidas por ela. Interessante que eram músicas country, também tinha música religiosa, mas ela escolheu as músicas. Eles oferecem todo o programa impresso, que é preparado pela própria casa funerária. É como estou falando, como eles programam com antecedência, dez dias, uma semana antes, tem tempo de você programar tudo isso. Aqui, como acontece muito rápido, 24 horas, não tem muito tempo para preparar, não tem muita preparação, é uma coisa rápida. Existe algum funeral que seja feito na igreja. Olha, eu nunca vi, eu nunca fui, agora já vi na televisão, por exemplo, onde morreu lá um político famoso, eles levaram o caixão, primeiro foi velado na assembleia legislativa, era ex-governador, depois, levaram o caixão num carro, até uma igreja, num cortejo. Eu acho que é mais para pessoas, assim, digamos, importantes, significado, público, enterro particular, não. Esse foi o único que vi lá por se tratar de uma pessoa pública, por ser um ex-governador, ele tem todas as honras, então, é bem diferente.

O cemitério, lá, nenhum fica próximo nem de uma igreja nem de uma casa funerária, não vejo nenhuma relação. Veja bem, se você está falando de igrejas muito antigas, católicas, elas tinham aqueles cemitérios atrás, isso tem. Você vê lá historicamente, hoje em dia, as igrejas não têm cemitério, o cemitério é municipal, fica no meio da cidade e não é perto de nenhuma dessas casas. Os dois que eu fui lá, em casas funerárias, não eram perto de nenhum cemitério, não. O cemitério lá é todo gramado, como se fosse o Jardim da Saudade. O que se vê lá são as lápides, não é como o cemitério do Caju, cada lápide de um tamanho. Lá, é todo padronizado, gramado, tem as ruas. Todo arborizado, como se fosse um parque, e você vê, realmente, que as famílias vão lá visitar, tumulo de alguém. Acho o cemitério do Caju extremamente deprimente, aqueles túmulos sujos, as figuras são mórbidas; lá, não, a ideia é mesmo de jardim arborizado, gramado, super bem cuidado, é limpo, e você só vê mesmo as lápides com os nomes e as datas. É tudo gramado, arborizado, super bem cuidado, então, não tenho certeza se as crianças que foram lá, se foram brincar, ou se foram com alguém. Com certeza, o ambiente é bem diferente. Aqui o Jardim da Saudade é o mais próximo do que a gente tem lá. Lá, não tem aquele cemitério como a gente tem aqui, túmulos suntuosos, eu nunca vi isso lá. No Canadá, a cremação é bem mais barato do que o 
sepultamento. A cremação, você vai pagar por aquele serviço, eles dão as cinzas a você e pronto, enquanto, no enterro, vai ter todo um trabalho, mão de obra, coveiro, arborização etc. A cremação sai bem em conta, não sei dizer quanto. Acho que hoje esse é o motivo de ser maior o número de gente sendo cremada do que enterrada. Quando o enterro é com corpo, esse velório é com o caixão fechado ou aberto. Quando eu fui, estava fechado, porém já em situações que ele estava aberto. Vi caixão com vidro onde se vê o rosto da pessoa, vi, na televisão, que estava metade aberto e tinha flores sobre o corpo, mais ou menos como aqui. Aqui é bem característico cravos vermelhos, lá, só mesmo em volta do corpo, decoração mesmo. Nos dois que eu fui, um nós, do escritório, compramos uma coroa de flores e mandamos e, no outro, pedia a doação em dinheiro para fundação de tratamento de Alzheimer. Quando meu pai faleceu aqui, no Brasil, eu vim para o sepultamento, e, quando retornei ao Canadá, tinha flores na minha casa. Os colegas de trabalho tinham mandado flores pra minha casa, eu recebi flores. Acredito que seja costume enviarem flores pra casa. Quanto à doação em dinheiro, nós fizemos diretamente no website da fundação. É interessante, eles têm um campo com o nome da pessoa, quanto você vai doar, $\mathrm{n}^{\circ}$ do cartão de crédito, tem um campo com o nome da pessoa para a qual você está doando. Acho que a família, depois, deve receber um relatório em nome da pessoa. No velório, não vi doação em dinheiro não, em casamento sim, é comum na entrada tem uma caixa e os convidados colocam os envelopes com dinheiro. Quanto à comemoração, com certeza deve ser mais de fundo religioso. Bem, o Canadá é um país de imigrantes, deve haver velório de todas as religiões possíveis: judeus, muçulmanos, católicos, protestantes. Acho que a religião da pessoa influencia muito no tipo de velório que vai ser feito. Nos que eu fui, as pessoas eram protestante, mas acredito que a influência religiosa é maior que a social. No aspecto social, a pessoa contrata uma casa melhor. No que eu fui, a música era tocada ao vivo, tinha uma banda tocando, no outro era gravação, quer dizer, o aspecto socioeconômico vai ditar essas pequenas diferenças que você sabe custam mais caro; mas, a cerimônia em si, é bem mais dirigida pela religião da pessoa.

Nos cumprimentos, é o tradicional "Meus pêsames", e as mensagens que as pessoas colocam no livros variam muito. As pessoas que têm menos intimidade com a família usam "Meus pêsames". Eu já vi, num dos funerais que fui, pessoas falarem "Puxa, eu tive o privilégio de conhecer essa pessoa através do trabalho", "Eu fui amigo durante cinquenta anos". As pessoas usaram aquele espaço não só pra confortar a família mas também pra celebrar a relação que tiveram com a pessoa que morreu; assim, a maioria das mensagem que li era mais pra marcar presença "Sinto muito pela sua perda". Outra coisa, vi também que pessoas levavam fotografias que tinha com a pessoa que faleceu, a celebração da vida com aquela pessoa. No Canadá, o contato, o toque é bem geral. O abraço não acontece em nenhuma situação, muito menos em velório. A maioria é aperto de mão. Se a pessoa tem um pouco mais de intimidade, um abraço, mas você não vê, como no Brasil, mais pessoal, mas isso é no geral; tanto no trabalho, nas amizades, não existe muito isso de toque como na cultura latina, lá não tem muito isso, um aperto de mão, um abraço bem formal, como você vê aqui. A família chora. Você vê que eles estão fazendo muita força. A parte que achei difícil lá e aconteceu comigo, é você falar sobre a pessoa que acabou de falecer. Pro filho falar sobre a mãe que acabou de falecer é muito difícil, mas choram sim, você vê que eles fazem muita força pra manter a compostura, mas choraram sim.

No primeiro funeral, não me choquei, achei diferente, nada me chocou não, mas fiquei pensando, mas, por exemplo, quando eu olho pra essa espera eu penso em duas coisas, primeiro, é dar oportunidade às pessoas que moram longe de vir, isso é um aspecto positivo da espera; por outro lado, prolonga o estresse, aquele sofrimento da família. O velório, lá, tem vários dias, então, a família vai vários dias. São ondas de pessoas, então, fica meio que prolongando, esticando aquele sofrimento. Não é que me chocou, até falo em casa que não precisa esperar tanto tempo não, quem veio, veio, quem não veio vai rezar por mim em casa. Eu, pessoalmente, meu muito particular, acho que coloca um peso muito grande na família. Durante todo esse tempo de espera, a pessoa não trabalha, a família não trabalha, você fica ali. À noite, a pessoa vai pra casa, mas recomeça no dia seguinte, depende da família. Nos dois velórios que eu fui, fizeram uma cerimônia íntima, só 
para a família. Depois, abriram essa casa, por dois dias, para os amigos. Então, pelo menos por três dias, a família foi lá. Não me chocou, entendo a cultura deles, mas pra mim prolonga muito o sofrimento deles. Acho muito tempo a família ficar ali relembrando, mas é uma questão de cultura, uma cultura diferente. A comida também não me chocou, mas achei muita comida, mas também tem uma razão por trás, é um enfoque de celebrar a vida. Uma coisa que é verdade, eles servem a comida no final, depois do funeral, durante aquela parte da comida as pessoas se acalmam, relaxam, as pessoas vão embora bem menos emotivas, bem menos emocionadas, do que estavam durante a cerimônia. Então, achei que a parte da comida é uma boa forma de você se distrair. Aqui, no Brasil, o ambiente é ruim, é chocante, todo mundo quer ir embora, se livrar daquela situação. Lá, depois que terminou, servem comida, bebida, chá, café. É uma festa, pessoas conversam se acalmam um pouco, e a família que estava emocionada, depois dessa parte da comida, já todo mundo mais tranquilo, não chora mais e você vai embora um pouco mais tranquilo. A última lembrança que você guarda é aquela da celebração e não a do funeral. Essa parte achei interessante, porque consegue relaxar um pouco as pessoas. Tiram fotografia. Essa senhora que foi cremada, não era um altar, mas montaram uma mesa que tinha a urna com as cinzas, flores, fotografias, dois ursinhos de pelúcia, que fazia parte da história que os filhos contaram. A mãe tinha um casaco de pele e fez dois ursinhos um pra cada filho. Então, as pessoas tiraram fotografias da mesa, com os parentes tiraram fotos, tinha um fotógrafo. Penso que as pessoas que estavam na festa também estavam na cerimônia. As cinzas ficam com a família que faz o que quiser. As dessa senhora, ela era de uma cidade pequena, os filhos foram até lá e jogaram num campo. Já ouvi histórias que as pessoas guardam as cinzas em casa, numa estante, mas se desfazem das cinzas de maneira significante. Lá também, como aqui, as pessoas não falam a pessoa morreu, falam fez a passagem. Durante a cerimônia mesmo, o pastor usa essas expressões, "Fez a passagem / elevação". Quando acontece de um criminoso, é tudo muito rápido, não vai ninguém. No máximo, a mãe e irmão comparecem, e, por trás, deve ter alguém que diz "Já foi tarde", mas nunca vi. Se a pessoa não tem recurso, o enterro vai ser custeado pelo serviço social, não vai para uma casa funerária, a pessoa fica no hospital só mesmo para a família. Essas casas funerárias custam caro, um velório nessas casas custa de US\$ 3 mil a US\$ 20 mil, se a pessoa não tem recurso, vai ser uma coisa mais simples no próprio hospital.

\section{Informante 16 BR}

Tenho 59 anos, nasci em Niterói (RJ), e minha família toda é de Aelesund, Noruega. Morei lá e em Oslo.

Assisti a um enterro aqui do pai de uma amiga. Foi uma das primeiras cremações no Brasil. Só assisti ao início com o caixão fechado. Aí, o caixão foi embora. A minha amiga me ligou, muito chocada, para dizer que tinham telefonado pra dizer a ela que horas iam ligar o forno. Ela não estava acostumada com isso.

O enterro do meu irmão foi o primeiro que assisti na Noruega, por isso, me chocou muito. Ele tava muito doente, mas ele não sabia. Ele tava com câncer generalizado. Na noite que ele faleceu, eu tava com ele e eu sabia que ia ser naquela noite, porque já tava muito mal. Tenho até impressão que deram mais remédio pra ele não correr o risco de acordar, ou de sofrer, porque acredito que seja muito doloroso. Na última semana, ele tava totalmente sem conversar. Ele já não comia, não bebia. Só molhavam os lábios dele. Eles não incentivam ficar continuando a vida. Aí, quando aconteceu, me disseram pra entrar em contato com uma firma de funeral. E minha mãe conhecia uma firma. Ela participou muito. Uma senhora veio e nos perguntou desde o tipo de caixão, perguntou qual tamanho de funeral que a gente esperava, a igreja em que íamos fazer. Lá quase todo mundo crema. Acho que é incomum, mas existem os enterros com caixão completo, mas em hipótese nenhuma acho que tem o negócio de caixão aberto e o velório. Meu marido chegou no dia seguinte e pediu pra ver o corpo, e nos levaram até o lugar gelado onde ele estava. 
Tem o hospital e tem esse outro lugar onde ele faleceu, onde a pessoa fica esperando a morte, uma última parada, né?

Disseram até que a gente podia dormir lá. Eu fiquei a última noite. Lá, já não tem oxigênio, não tem intravenoso, nada, nem nenhum tipo de tratamento. Só o remedinho pra manter a pessoa sem dor e calma, dão banho, quarto bom, televisão, um sofazinho onde eu descansei. É como se fosse uma casa com quarto de enfermagem. $\mathrm{O}$ subsolo era um frigorífico. O senhor da funerária me disse: "Eu vou estar te esperando lá" quantas pessoas são. Ele estava vestido, todo arrumadinho como se estivesse dormindo. Nós não fomos num lugar cheio de gavetas não. Claro, foi traumático, mas fizeram da melhor forma possível.

Lá, não colocam flores dentro do caixão. A funerária mandou uma senhora pra conversar comigo e com minha mãe, e marcou o dia do funeral pra uma semana depois. Porque eu acho que é o tempo que você tem pra preparar o funeral. Marcamos a data e perguntaram que tipo de flores que nós queremos e quantas coroas. O caixão fechado, mas com flores em cima, uma coroa com laços escrito de saudades e o nome das pessoas, cada família enviou uma dessas. Algumas levaram flores na mão. Já não tinha mais lugar em cima do caixão. E tudo isso fica no altar da igreja, a igreja era pequena com cadeiras sentadas bem perto e o caixão. Todo mundo, antes de sentar, cada um vai lá, na frente, e lê cada mensagem que tem na flor. Não houve missa, mas uma celebração. Nós somos protestantes luteranos pelo batismo, mas não somos religiosos. Mantemos a tradição social batismo, como se fosse uma comunhão, crisma. O padre foi lá em casa nos conhecer, perguntou sobre meu irmão, pra, no funeral, fazer uma pequena celebração, rezou. Escolhemos as músicas, que eram músicas cantadas, músicas típicas de igreja, enterro. O cemitério é um lugar bonito, em volta da igreja, crianças brincam, cachorros correm. É um parque. Todo cemitério lá é lugar de passeio. Todo verde com as pedras, com os nomes. É tudo baixinho, não passa de $50 \mathrm{~cm}$. Tem que é família e tem uma pedra maior.

Nós deixamos um livro com a foto dele, porque eu queria a assinatura de cada pessoa que foi. Alguns escreveram alguma coisa, outros só assinaram o nome. Nós pedimos, no anúncio do jornal, que, em vez de flores, fizessem uma doação para o fundo de pesquisa de câncer. É muito comum isso. É uma forma de não ficar com aquelas flores todas dentro de casa, né? Quando não podem ir à igreja, mandam pra casa. Uma amiga mandou flores com cartão e foi ao enterro. Outra não pôde ir e nos mandou um bolo que ela fez. É só uma gentileza, pra não deixar em branco. Algumas levaram flores pro enterro e colocaram no altar junto com outras. Não tem uma regra. Pra mandar entregar, lá, é muito mais caro do que a coroa. Por isso, é comum levar as flores. Lá, quase não tem coisa de entrega, sai caríssimo. É comum levar as flores.

Cumprimentos: Ficamos em pé, na entrada, e quem chegava nos cumprimentava. Quem chegou atrasado sentou e depois veio falar conosco. E todo mundo depois veio falar conosco. Normalmente, se faz uma reunião, você aluga um espaço num restaurante, café, ou em casa e oferece bolo, chá, café e faz uma coisa assim pra todo mundo ir depois do enterro, mas eu e minha mãe estávamos abaladas. A maioria tinha ido visitá-lo no hospital e disse: "Triste que ele foi embora", "Estamos muito sentidos", "Que perda", "Como sua mãe agora vai ficar". Os colegas dele ligaram antes, ligaram depois. Uma das colegas dele levantou e fez um discurso sobre ele de 5, 10 minutos, elogiando-o. No trabalho, todo mundo contava com ele. Não é abraço, beijo, não. $\mathrm{O}$ povo lá não é de se abraçar, de se beijar, não. As pessoas são mais de cumprimentar, e quando tem o abraço, antes tem o aperto de mão. Quando são duas mulheres, amigas íntimas, primas, vão direto pro abraço. Usam "Meus sentimentos" sempre. Quando tem o abraço, o aperto de mão vem primeiro.

Não usam expressões que suavizam, falam "morreu" mesmo. Se a pessoa que faleceu for muito idosa, ou se já havia uma expectativa de morte, dizem: "Dormiu silenciosamente". Isso se usa muito no jornal e a gente entende que não foi um desastre nem acidente. A pessoa já estava doente, ou muito idosa. Corresponde, no Brasil, a ele descansou. Falam também "Dormiu silenciosamente pra dentro". Expressões grosseiras, acho que não existem. Lá quando a gente fica com raiva de alguém diz: "Vai pro inferno!", mas, no caso de morte acho que não tem. 
Normalmente, não enterram com menos de uma semana. Pode levar 10 dias, não é problema. $\mathrm{O}$ corpo fica no lugar gelado que é grátis como o hospital. Ele não tava em caixão não. Tanto é que levei roupa pra ele. O hospital colocou roupa que tinha lá. Calça jeans, camisa xadrez. A funerária trocou a roupa, mas levei um terno. O padre perguntou se queria que as pessoas dessem o último adeus com o caixão aberto. $O$ corpo não foi embalsamado, não. Do jeito que saiu do hospital foi pro lugar frio. Fica só no frio, e saiu de lá algumas horas antes do funeral. Quando chegamos na igreja, já estava lá, no altar. Quando terminou a cerimônia, abre um buraco e o caixão desce e vai pro crematório. Quando termina a cerimônia, o chão abre e o corpo desce. E o chão fecha de novo. Eles tiram as flores que tava em cima, as flores e, no dia seguinte, colocam no cemitério. No cemitério tem tantas árvores, aquelas que fazem árvore de natal.

Já tava uma cruz com o nome do meu irmão com data de nascimento e morte, e já tava enterrada a urna dele. Tem gente que quer ficar e ver o caixão ou urna ser enterrada, as cinzas enterradas. Nós não participamos, foi uma opção nossa. Ficamos só até a cerimônia. Então, cheguei lá no dia seguinte, e estavam lá todas as flores e laços em volta da cruzinha branca.

Normalmente, depois do enterro, as pessoas se reúnem pra comer. Tem hora, pois escurece muito no inverno. Não tem uma sala na igreja pra ficar conversando com todo mundo. O padre é que fala. Então você convida pra casa ou pra outro lugar.

Eu fiquei com mais contato com a família. As pessoas iam visitar meu irmão, e eu ficava conversando com os familiares. No hospital, no quarto, ou no lar. Lá tinha café, bolinho.

Fui a vários velórios aqui, mas, minha sogra faleceu e foi muito, muito bonito. Ela deixou um documento dizendo que queria ser cremada. Ela foi cremada e as cinzas dela foram levadas pra Recife, onde ela nasceu. Sentimentos: Eu acho que aqui as coisas acontecem tão rápido, mal a pessoa morreu já tem que enterrar, muitas pessoas que gostariam de ir não conseguem chegar, às vezes, as pessoas não ficam nem sabendo. Acho que está todo mundo numa tristeza tão profunda que você não percebe direito o que está acontecendo. Acho que isso é ruim. Às vezes, é um estresse só.

O último foi enterro, não foi cremação. O velório foi no $2^{\circ}$ andar, no Cemitério do Caju, e a senhora que faleceu era muito gorda, o corpo era muito pesado, fazia muito calor, a gente ria, não esperava uma coisa dessa, foram até o mausoléu da família, mesmo em cima de uma coisa de rodas. No meio do caminho, o coveiro parou pra atender o celular. No velório, todo mundo rezou junto e cada um da família chegou perto e depois veio a mãe e falou: "Sou a mãe dela e ela passou a minha frente".

Lá, na Noruega, eles primam pela celebração, e a maioria das pessoas querem tudo pensado. Ele gostava dessa música, vamos tocar essa música, ele gostava deste texto. Então, vamos escolher isso. Os que falaram, falaram muita coisa bonita. O padre falou umas coisas bonitas sobre a vida e a morte. Ele não nos conhecia, foi lá em casa dias antes pra saber de nós. As igrejas lá são luteranas, mas tem uma pequenininha católica. Eu não conheço nenhum norueguês católico. Polonesa, brasileira são católicos. O Estado é luterano. Igreja e Estado não são separados.

A amiga da minha mãe, é norueguesa e depois de idade morou aqui. Ela vai ficar até setembro. Tenho outra amiga que acabou de ficar viúva. Ela morou aqui por muitos anos, trabalhando no consulado. Eles não querem cerimônia religiosa. A família não quis que o marido ficasse em aparelhos, só o tempo de os parentes chegarem. Ela é bem cuca fresca. Eu fico chocada, mas é a visão deles. Ela falou que ele foi embora, mas ela está bem. O oxigênio só ficou ligado até os parentes chegarem, logo depois, desligaram e ele morreu. Tudo dele foi planejado há anos. Ele era 18 anos mais velho do que ela. Ele já tinha o funeral preparado há vinte anos, tudo o que ele queria, até as músicas. Quis ser cremado e as cinzas jogadas no terreno da casa de montanha deles. 


\section{Informante 17 BR}

Moro na Noruega há 34 anos e tenho 62 anos. A minha avó faleceu em casa, em Petrópolis, e o velório foi em casa mesmo, à noite inteira, e ela foi enterrada no dia seguinte pela manhã. Foi interessante porque foi, assim, quando eu já tinha 10 anos. Aí, eu comecei a entender melhor um funeral, essa coisa de a pessoa morrer e ser enterrada. Foi o primeiro funeral que eu fui. Isso há mais de 50 anos. O caixão ficava, na sala, em cima de uma mesa, aberto, de maneira que quem quisesse fazia uma oração. A família ficava toda reunida. Dava tempo de a família chegar. O enterro era no dia seguinte pela manhã, cedo.

O outro enterro que eu fui foi do meu primo que tinha 26 anos. Mas, aí, acontece muito rápido. Ele tava internado no hospital e de lá mesmo o corpo foi enterrado no mesmo dia. Não teve aquele velório durante a noite, o enterro foi rápido, no mesmo dia. Na hora dos cumprimentos, as pessoas diziam "Meus pêsames", ou então, às vezes, nem falavam nada, ou só falavam "Oh, que pena, ele era tão novo", "Ele descansou agora". Eram palavras assim. As pessoas mais íntimas conversavam muito sobre como a pessoa era normalmente quando tava saudável. Ele morreu com 26 anos, se esperava porque ele tinha câncer, mas, de uma certa maneira, né? Então, eram assim as palavras. Pra mim aconteceu muito rápido. Teve que organizar muito rápido o funeral, o cemitério. Sempre achei o enterro no Brasil uma coisa macabra, de uma certa maneira que. Ele foi colocado numa gaveta e depois foi feito o translado para o jazigo da família no Rio. O cemitério muito cheio, tudo entulhado, quase não dava pra andar. Eu não era muito chegada a enterro. Nunca fui, na realidade. Isso, no Brasil, onde os familiares choram publicamente. Choram e mostram os sentimentos. Choram muito na hora que a pessoa vem ver, e também na hora que o coveiro leva o corpo, a hora do último adeus. A pessoa chora porque aquilo ali é o adeus definitivo. A pessoa abraça com lágrimas nos olhos. A pessoa se comove muito diante da morte. Era muito contato físico. A pessoa mais próxima ficava assim abraçadinha. Às vezes, não falava nada, às vezes, falava e coisa e tal. Não vi nenhum aperto de mão, não.

Moro aqui há 34 anos. Desde que cheguei pra aqui, pra Noruega, em 1980, eu trabalhei como enfermeira. Desde que vim pra cá. Já trabalhava como enfermeira no Brasil, no Hospital de Ipanema. Este ano me aposentei no serviço público. Eu era enfermeira da emergência, fiz o curso de professora de enfermagem. Aliás, eu dei aula no Brasil e continuo agora dando aula.

$\mathrm{Na}$ Noruega, não me chocou. $\mathrm{O}$ funeral me surpreendeu de uma maneira positiva. Eu acho que, por exemplo, aqui a pessoa, quando falece, ela fica seja lá onde ela faleceu, tanto no hospital como no asilo pra idosos. O asilo aqui é como um hotel, na realidade. A pessoa tem os cuidados médicos e, ao mesmo tempo, tem um conforto muito bom. A pessoa, independente de onde faleça, tanto em casa como no hospital ou em qualquer outra instituição, você liga pra funerária. Todas os hospitais, as instituições têm um local gelado que a pessoa fica lá, mas aí é tudo bonitinho tem mesa. É gelado, mas não é assim tão gelado, mantém uma temperatura assim. A funerária vem, pega, né, vem buscar o corpo e já coloca dentro do caixão arrumadinho, tudo bonitinho. Se a pessoa quiser que a pessoa fique com a roupa própria, já coloca a roupa que quer ficar, ou, então, eles têm uma roupa especial que é muito bonita também, é uma camisa muito assim branca, muito bonita que serve tanto para homem como para mulher. Coloca uma roupa e tal e ali já coloca no caixão. E, se os parentes quiserem, amigos quiserem vir fazer, eles geralmente demoram uns dois dias pra vir pegar pra levar pro crematório ou pra igreja. Eles têm um lugar especial onde fica o cadáver até ser enterrado. Demora mais ou menos uma semana. Nesse ínterim, aí, a pessoa avisa a todos os parentes e amigos, sai no jornal. Aqui, como o lugar é muito pequeno, todo mundo vê na mesma hora, todos os dia, praticamente, quem morreu, quem não morreu e tal. E, aí, já tem a hora. Eles colocam no jornal, tem uma pequena reunião com a família e vê quem é que vai sair no anúncio, qual o familiar, neto, quais os familiares que vão sair, já colocam onde vai ser o enterro, o horário, porque, aí, já organizaram com a igreja ou crematório, né? Tô falando do funeral cristão. Depende da família. Se quiser no crematório, já vai direto pro crematório. Se for na igreja, vai primeiro pra igreja e depois levam o caixão pro crematório. Nesse ínterim, já sai no jornal, ele já 
faz os panfletinhos que ficam na igreja. Você tem uma reunião, se for na igreja ou no crematório, tanto faz, você tem uma reunião com o padre porque o padre vai falar sobre a pessoa. Você fala o que quer ressaltar, se vai cantar alguma música religiosa, algum salmo, se vai cantar algum tipo de música, se alguém vai falar alguma coisa, e, nesse ínterim, também, eles providenciam as flores. Se você quer fazer coroas, a coroa já vem o nome das pessoas, com os dizeres que quer falar, por exemplo, "Uma última saudação", aí o nome das pessoas, aí faz aquilo tudo onde as pessoas encomendam flores, mas a funerária cuida da ornamentação da igreja, das flores dos parentes, então, tudo eles fazem. A pessoa, então, durante essa semana, tem a reunião com o padre e tem aquela oportunidade também de sentimento, de sentir, de descansar e tal, uma preparação. Aí, chega o momento do enterro. No momento do enterro, lá, é aberto pra parentes e amigos. Como é uma semana depois, geralmente vem muita gente. Mas é uma coisa bem formal, tem muitas lágrimas principalmente quando a pessoa vai dizer algumas palavras, tem também lágrimas quando a pessoa diz "Meus pêsames", "Minhas condolências" ou então só abraça. A família aqui tem sentimentos também, outras pessoas só fazem um aceno com a cabeça. E, mas, geralmente, a família fica na porta, no final do funeral. Primeiro, lá, durante a cerimônia, que é muito bonita. Noooooossa senhora! É muito bonito! É honrosa, sabe? Não tem aquela choradeira, gritadeira, não, mas as lágrimas caem, a pessoa sente, entendeu? Mas é o padre que fala muito bem, lê todos os dizeres que estão nas flores. Sempre tem uma faixa, né? Lê os dizeres e, na hora de sair, são os familiares ou amigos que carregam o caixão até a porta. Ali está a funerária esperando e leva o caixão. Aí, todo mundo já vai saindo e espera até a funerária levar o caixão. E a família fica ali e recebe os pêsames, as condolências, e cada um vai pra sua casa. Em termos, porque, geralmente, tem uma recepção. A pessoa reúne todo mundo, aí, tem comida. Ou é frio, bolo, aí reúne todo mundo. Aí, é bem descontraído, todo mundo fala sobre o falecido mais descontraído. Sempre tem aquela cerimônia, aquele encontro, aí você, naquele encontro, você convida os familiares e pessoas mais próximas, e, aí, você fica ali. Familiares que não se veem há muito tempo se encontram e conversam, veem fotos, se lembram, entendeu? É uma recordação. Todo mundo fica numa reunião, fica mais social, mais descontraído. Sem álcool totalmente. Só café mesmo, refrigerante, água, sanduíches frios, com camarão, carne assada mal passada, salmão, faz aquelas bandejas. Você encomenda pronto. Bolo, alguém faz e traz, ou a gente encomenda também. E fica aquela reunião, a pessoa conversa sobre muitas coisas. Quem não se vê há muito tempo mata as saudades, a parte mais jovem da família que, às vezes, não se conhece fica se conhecendo os filhos e tal. O funeral da tia do meu marido foi feito na igreja e depois foi pro crematório. $\mathrm{Na} 2^{\mathrm{a}}$ agora, a gente vai colocar a urna na terra, aí, é uma pequena cerimônia só com a família. É tudo muito respeitoso. Você sabe, o pessoal aqui não é muito assim de mostrar sentimento, não. Tudo é na base da discrição. Aqui tem também o abraço, mas tem que ser muito chegado pra ter abraço, fora isso, não tem não. Depende do conhecimento. Abraço, abraço não é muito chegado aqui não. O pessoal é bem reservado. E outra coisa, o cemitério aqui é uma coisa de passear. É todo gramado, não tem cimento. Tem flores. Todo mundo cuida muito bem das pedras, pedras de mármore que têm os nomes dos mortos. E muita gente vai passear mesmo. É um jardim muito florido. É muuuuito bonito. Muita gente vai passear mesmo. Tem caminho pra passear. Eu ando muito mais descontraída aqui, pelo cemitério daqui que é todo aberto, não tem grade, não tem nada, do que ando no Brasil. Eu tenho horror de ir a cemitério no Brasil, porque eu tenho uma má impressão das vezes que fui. Acho uma coisa, parece ter sido tirado de filme de terror. Aqui, as pessoas vão sempre cuidar das flores. Tiram e plantam outras que levam. No inverno, tem as flores especiais que atura a neve, que atura tudo, entendeu? Se o tempo está bonito, vamos lá, no cemitério. É uma coisa normal. Levam crianças, ninguém fica com medo.

Logo que morre, o falecido vai prum quarto espaçoso onde tem a mesa. Ele já foi arrumadinho, porque quando ele desce, a funerária vem logo e arruma. Fica nesse quarto da funerária ou em uma instituição. Tem hospitais muito grandes com três quartos, com a temperatura baixa, mas não é tão baixa que você não possa entrar, entendeu? Mas, se a família é pequena, vai direto pro crematório, ou vai direto pra igreja. Quando não são cremados, vão direto pra igreja e 
de lá, vão pro cemitério. Aqui, no cemitério, coloca mais a urna do que o caixão, porque não tem mais espaço pra enterrar o caixão. O cemitério aqui é tipo um jardim, não tem muito espaço. Então coloca só as urnas. A gente fala "Vou ver minha sogra". Geralmente, aqui, o cemitério é ao lado da igreja. Enterram a urna, ou levam pra outro lugar caso tenham outros planos. Quando eu morrer, quero ser cremada, e parte das minhas cinzas ficarão aqui e outra no jazigo da família no Brasil. A urna é de metal, resistente. O corpo é cremado sempre depois do velório. A maioria da Noruega é protestante. A funerária, normalmente, leva o corpo pro crematório que fica lá até a hora do funeral. No dia do funeral, o pessoal da funerária recebe a família, ajuda o padre a suspender as faixas, dá apoio à família o tempo todo. Até o momento do enterro ou da entrega da urna à família. Quando você chega na igreja, já está tudo arrumado: as flores, as luzes, tudo. As pessoas e o padre chegam meia hora antes e esperam a cerimônia começar. Cada um, na entrada, pega seu panfletinho, onde há o ritual de todo o funeral, o que vai ser feito o tempo todo. O ritual do funeral pode ser no crematório. Se a pessoa não é muito cristã, não tem nenhuma orientação religiosa, faz o funeral no crematório mesmo, onde tem tipo uma igreja. É igualzinho uma igreja. Mesmo a pessoa não sendo religiosa, sempre é um pastor que conduz o funeral e o enterro. A não ser que a pessoa não queira e deixe isso bem claro. Os salmos são diferentes e as músicas também.

O anúncio no jornal já é automático. É a funerária que organiza isso. Se a morte era esperada, pra comunicar o aviso de morte, usa-se a expressão "Adormeceu". A morte aqui é uma coisa que, por pior que a pessoa tenha sido, quando não era uma boa pessoa, não se usam expressões grosseiras, não. Meu marido que é norueguês disse que, antigamente, se falava "Foi bom ver que ele está debaixo da terra agora", "Ainda bem que ele está debaixo da terra agora", "Ainda bem que ele foi embora pra sempre", "Foi bom ver que ele foi embora pra sempre", "É bom ver ele bem". Hoje não se usam mais essas expressões, que faziam parte de um dialeto. Hoje, pelo contrário, a pessoa morta é muito respeitada, os sentimentos vão pra família, tem um respeito por quem fica. Hoje, usa-se "Foi embora", já se sabe "Foi embora pra sempre". Nada que menospreze, ridicularize uma pessoa que faleceu. Prum amigo, referindo-se à pessoa querida, dizse "Fulano adormeceu pra sempre", "Foi melhor porque estava sofrendo muito", no caso de morrer de câncer. Mas, nos hospitais, eles são muito diretos. Falam "Seu irmão morreu, às tantas horas, por causa disso". Usam mais faleceu. No jornal, por exemplo, a comunicação da morte é suavizada por: "Após um longo tempo de doença, a pessoa adormeceu", "Dormiu tranquilamente para sempre". Se a família é muito religiosa, usa-se "A pessoa agora foi para junto de Jesus". Você conversa com a funerária e escolhe os dizeres que quer colocar. Existem os padrões, mas a família pode indicar o que quer que seja escrito. Outra coisa, também, se você não quiser fazer nenhuma cerimônia, já coloca no anúncio a informação: o ritual termina na igreja. Aí, já sabem que não vai ter encontro depois, não vai ter nada. É muito comum aqui combinar com a funerária para colocar, no anúncio do jornal, "Não queremos flores, queremos uma contribuição para a pesquisa do câncer". Aí, todo mundo que vai, geralmente, já coloca direto na conta da pesquisa do câncer. No dia do funeral, a pessoa põe, numa cestinha, um envelope com o recibo e um cartão de condolência onde muita gente escreve umas palavras e põe ali "Foi depositada na conta da pesquisa do câncer uma contribuição". A família lê todas as mensagens e depois escreve de volta, agradecendo. Você pode fazer isso mesmo. É mais assim formal. O corpo não é embalsamado, a não ser que vá pra outro lugar, pra longe. Aqui, na Noruega, não. Nos vilarejos mais longe, ainda enterram. Aqui, é mais cremado. Nos vilarejos, o cemitério fica no pátio da igreja, sempre no pátio da igreja. Tem um livro onde, no final, a pessoa se registra, escreve o nome, mas varia. Isso é opcional. A família pensa antes e decide. Se a pessoa não tem família, o que acontece muito aqui, e fica doente, tem sempre um tutor que é nomeado pra cuidar do funeral e do enterro. Aí, já é mais simples. 


\section{Informante 18 BR}

Meu nome é Marcelo, sou carioca, casado com uma norueguesa, tenho 49 anos e moro na Noruega há 4 anos e meio. Aqui, trabalho com esporte, sou treinador de futebol, estou escrevendo um livro, sou músico, mas o que me sustenta mesmo é um hotel que tenho em Ipanema, na Barão da Torre. Chama Bonita Ipanema.

As expressões de cumprimento, no Brasil, são "meus pêsames", "que pena", "que perda". Todo mundo fala bem do defunto. Às vezes, tem uma outra pessoa que faz uma fala mais elaborada pra todo mundo. Não gosto de funeral, então, eu não gosto de nenhum tipo, porque eu acho que é triste, parece que falta alguma coisa. Aí, no Brasil, os cemitérios são muito tristes, o João Batista e o Caju são feios. É muito cimento. Parece que falta alguma coisa no funeral no Brasil. Em relação ao contato físico, o brasileiro é mais caloroso o tempo inteiro. Com certeza que, no funeral, também. Mas se for comparar com a Noruega, nessa hora, também, tem o abraço, esse contato. Essa é a hora que os dois países ficam mais próximos.

Na Noruega, eles enterram muito depois do que a gente no Brasil. Uma semana, ou mais, pra ter o enterro. Sei que esse espaço é bem grande. Como aqui é frio, desde o tempo que não tinha geladeira, o corpo dura muito. A pessoa morre hoje, fazem o enterro no fim de semana. Fui ao enterro do avô da minha mulher. Ele estava bem velinho. Eles esperam as pessoas comprarem passagem pra vir de longe. As pessoas se vestem muito bem em comparação ao Brasil. Os homens vão de terno, as mulheres vão muito arrumadas. É comum usar uma roupa típica que só mesmo no Natal e no dia 17 de maio, que é o dia da Noruega. Não usam nem em casamento. Cada mulher tem da sua região. É bem bonita, colorida e muito cara, tem muitos enfeites mesmo, bordados, colar. Elas se enfeitam muito mais. Cada região tem uma cor. Daqui, dessa região onde eu moro, a roupa é verde ou azul. O homem vai de preto porque o terno é preto. Minha região fica bem no meio da Noruega. Uma diferença grande também é, nunca vi aqui cemitério de cimento. Todos são bem bonitos, todo gramado, com lápides pequenas. Outra diferença grande é a música. Aqui, na missa, sempre tem muita música. Todo mundo canta. Eles aqui cantam muito bem. Não tô acostumado a ir tanto à igreja no Brasil, mas tem duas coisas que eles fazem muito aqui na igreja que é cantar e fazer discurso. Todo encontro, assim, batizado, aniversário, casamento, qualquer celebração tem muito discurso, uma declaração. No funeral, eles vão lá, na frente da igreja. No funeral em que eu fui, foram umas vinte pessoas lá, na frente, falar, de cinco a dez minutos, sobre ele, entre filhos, netos e amigos. Isso tem sempre. É comum, também, eles cantarem, ou botar uma letra diferente em alguma música, ou até mesmo fazer uma própria música e cantar. Aqui, todos são muito musical, né? Isso faz, também, que as pessoas saibam cantar. Todo mundo aqui canta muito bem. Não dançar, não, mas cantam muito bem. A igreja é protestante. Aqui quase não tem igreja católica. A maioria das pessoas é protestante. Quanto a flores e a velas, aqui é muito parecido com o Brasil. No caixão, que fica no altar, sempre tem flor. Quando alguém vai pra dar tchau ou o adeus, coloca uma flor em volta do caixão que fica fechado. Outra coisa que vi aqui foi um livrinho de três ou quatro páginas, com a foto do falecido, o nome. A capa é como se fosse uma lápide. Dentro, tem fotos e informações sobre o falecido. Você recebe na entrada da igreja. Tem o livro de assinaturas da igreja também. Depois, tem um almoço. Vai todo mundo prum outro lugar grande, assim. Na verdade, o ritual é parecido com todas as festas, como um aniversário, por exemplo. Você vai na igreja, senta, tem música, muita gente vai lá na frente falar alguma coisa sobre o aniversariante. Depois, você vai comer. O funeral foi igual. Depois, foi todo mundo almoçar em outro lugar. Lugar grande com muitas mesas redondas, o buffet, assim, onde todo mundo vai socializar um pouco. Essa é uma diferença grande do Brasil. Não teve bebida alcoólica, mas essa família não bebe bebida alcoólica nas festas. Deve ser porque tem muita criança, mas, em casa, eles bebem, mas na festa não. Ele morreu num lar pra idosos. É confortável, tem um quarto só pra ele. Demora quase duas semanas pro corpo ser enterrado. Quando ele morreu, eu pensei que a gente ia correr pra lá, que é outra cidade, mas minha esposa disse não. Estranhei um pouco, me surpreendeu, mas nada incomoda. Só fiquei pensando naquele corpo se deteriorando. A diferença é 
muito grande, né? Como tudo que é de cultura diferente, a gente estranha, mas nada incomoda. É surpreendente.

O sepultamento foi logo depois da igreja, mas a gente não participou. Acho que ele foi cremado. A gente não viu, deixou a igreja com o caixão no altar. Aqui tem anúncio no jornal. É parecido com o Brasil, uma ou outra pessoa. Ele não tinha mais casa. É comum levar flor pra enfeitar o altar. Quem não tem flores, recebe uma rosa pra colocar no altar. O que achei mais diferente foi a música. Fiquei muito impressionado. Eu sempre fico impressionado quando vou à igreja. As melodias, eu sou músico também, as melodias não são fáceis, são difíceis de cantar, e as pessoas cantam... Até minha mulher, que não canta, mas, na igreja, ela canta, todos cantam, crianças. Todos cantam numa afinação incrível. Melodias que não são fáceis de cantar. E fica muito bonito. Tinha um órgão, também, ao vivo, lá. O que mais impressionaria um estrangeiro, acho que são as roupas. São, realmente, lindas. Tem tudo, sabe, cinto sapato, chapéu, colar. É muito tradicional. Tudo muito colorido, alegre.

No almoço, continuaram as declarações, devia ter umas quinze mesas, cada uma com dez pessoas. Era bastante gente, e, aí, você ouvia alguém bater no copo trim, trim, trim. E todo mundo tinha que parar de comer, ficar quieto porque alguém tinha alguma coisa a falar. Não é triste. É emocionante, sabe? As pessoas mais próximas recebem abraços, você abraça também. Apesar deles não serem nada calorosos, nesse momento, eles são. Na missa, eles choram muito, talvez mais do que aí. Não só no missa, mas em todas as outras celebrações como aniversário. Nisso, eles são muito emotivos. Todo aniversário que eu fui teve choro quando uma pessoa começa a falar. Às vezes, alegre, outras triste, emocionante. É choro direto. É só alguém começar a falar.

Por minha experiência de morar fora, já morei em outros lugares, não cometi nenhuma gafe. Sou muito cuidadoso. Fico na minha, vejo o que estão fazendo, sempre espero pra fazer depois, porque tem muita coisa diferente. Senão teria gafe sim porque as coisas são diferentes. Onde botar a rosa, que horas cantar, que horas levantar, se pode falar. Esse negócio de bater no copo e não poder tocar na comida, não poder comer, a gente vai aprendendo.

As expressões usadas aqui são as mesmas: "minhas condolências", "Que homem bom que ele era.". É muito parecido. Não vejo muita diferença, não. Os noruegueses são muito mais diretos do que a gente, então, eles não usam eufemismos. Falam "faleceu", "morreu". Se morreu de acidente, é outra palavra. Só conheço em norueguês e é uma palavra diferente, å omkomme. Aqui, não conheço nenhuma expressão grosseira que indique que alguém morreu. Acho que não existe esse tipo de expressão. Eles são muito educados no trato com a palavra. Eles são diretos, não gostam de dar muita volta pra falar alguma coisa, mas não são grossos a esse ponto. A morte é uma coisa muito séria, né? Acho que uma gafe seria fazer uma piada com o morto. O funeral não é uma cerimônia triste. Em geral, é uma cerimônia mais pro alegre mesmo. Acho que é perigoso fazer uma piada que não seja muito bem feita.

Como ele era uma pessoa mais velha, tinha 92 anos, você não diria que era um funeral. Fora o choro da igreja e tal, você não diria que era um funeral. Vira um aniversário. Na hora do almoço, é só alegria, criança correndo. É uma festa. Como as roupas, também, não demonstram nada. Os homens tiram o paletó, ficam de camisa branca, e as mulheres todas coloridas. Você não diria que é um enterro.

Nesse mesmo funeral, o tio da minha mulher tinha acabado de perder um filho de acidente de carro. Tenho certeza de que esse funeral foi um pouco diferente. Era um rapaz muito novo e saudável. 


\section{Informante 19 BR}

Tenho 36 anos, sou pedagoga, morei 7 anos na Noruega, em dois lugares diferentes, num povoado e numa cidade de 200 mil habitantes. Se não me engano acho que já fui em três funerais por lá. Fui em dois na cidade onde morava e já fui num em uma ilha, no interior da Noruega, um lugar pequeno. Hoje, na Noruega, a maioria dos corpos é cremado, ainda enterram o corpo, mas a maioria dos corpos é cremado. Eu fui no enterro de um norueguês que era casado com uma brasileira. A maioria das igrejas lá já tem um cemitério ao lado e, aí, foi uma cerimônia, porque, na Noruega, tem a questão que eles enterram o corpo depois de sete dias que a pessoa morreu, tem a questão da família ter tempo pra preparar o enterro, enquanto o corpo fica na funerária. A funerária vai cuidar do corpo, vai vestir a roupa, vai enfeitar e a família, vai ter um tempo pra convidar as pessoas, colocar no jornal o anúncio, avisar os amigos, os parentes, o pessoal que mora longe vão chegar. Quando vai ter o enterro, já é um tipo de um cerimonial junto, no que eu fui tinha pastor, às vezes acontece da pessoa, da família ser ateísta é outro tipo de cerimônia, normalmente tem pastor, esse tinha pastor, a maioria na Noruega é luterano, aí fazem a cerimônia, cantam as músicas enquanto o corpo fica lá na capela, fica na igreja, ninguém vela o corpo como aqui no Brasil, na minha região, que eu sou do Tocantins; a cerimônia leva 1 hora, 1h 30min na igreja; nesse lá que eu fui achei interessante porque era uma capela só pra funerais mesmo, pra enterrar a pessoa aí de lá onde já estava o caixão, já tinha como se fosse um elevador que já levava o corpo direto pro crematório, ninguém precisava carregar nem nada, nesse caso já desceu. O caixão desce e vai direto pro crematório, esse que eu fui; e depois disso tem uma cerimônia com a família, a família costuma convidar as pessoas que estavam lá pra ir a algum lugar pra comer alguma coisa, eles servem pãezinhos com presunto, isso depois do enterro, nesse caso o corpo foi cremado, não teve enterro; o corpo da capela foi direto pro crematório e a gente vê não mais, depois de uns dias a família vai receber a caixinha com o pó, o corpo já cremado, e aí eles vão enterrar. O cemitério lá não é como no Brasil, no Brasil tem aquele negócio, como é que se chama? Jazigos, né? Lá na Noruega o que eu achei diferente, né da qui no Brasil é que aqui no Brasil a gente vê muita desigualdade social no cemitério, vê jazigos grandes, com várias famílias, com mármore, granito, muitos enfeites no cemitério aqui no Brasil, lá praticamente toda pessoa tem uma cova igual, um gramado e cada pessoa tem uma pedra, que eles fazem, põem o nome da pessoa que faleceu, a data de nascimento, data de quando faleceu e uma frase que a famílias deixou pra aquela pessoa, e um espaço pra jardim bem pequenininho pra uma flor, e praticamente todo cemitério é igual, é mudar o tipo de pedra, a cor e o tamanho, mas não vai ter muita diferença. Esse foi o primeiro que eu fui.

Ano passado teve o funeral da minha sogra que faleceu, esse foi na igreja local do bairro lá, foi mais ou menos mesmo estilo, depois de 7 dias que ela faleceu. Eles fizeram o funeral, quando eu cheguei lá, eles já tinham organizado tudo, encomendado flores, convidado as pessoas. Esse enterro da minha sogra achei bem bonito, parecia que se estivesse assistindo a um filme, todos os conhecidos, todos os amigos, todos bem vestidos, elegantes, de preto, foi bonito porque eles contaram a história da vida dela, isso na igreja. No dia do funeral, a pessoa chega na igreja o corpo já vai estar lá na igreja, no centro da igreja, tem o pastor, as flores que as pessoas mandaram, os familiares recebem as pessoas e se cumprimentam, se abraçam, as pessoas vão entrar e se sentar; antes disso a família já sentou com o pastor pra organizar a cerimônia toda, a questão de escolher as músicas, contar a história de vida da pessoa, o que ela fez de bom, se alguém quiser fazer um discurso faz, aí tem o discurso, tem várias coisas, nesse dia chamaram também uma pessoa pra cantar, uma solista, muito bonito, cantou a capela, nesse dia foi muito bonito estava fazendo sol, geralmente lá chove, aí estava fazendo sol, de lá quando a cerimônia acabou, os familiares pegaram o caixão e levaram pro carro da funerária. No caso dela, o corpo não foi cremado, foi enterrado, e levaram pro cemitério que é perto, enterraram o corpo, diferente do Brasil, a gente já joga terra na hora, lá enterraram o corpo deixaram lá dentro do buraco, jogou-se simbolicamente a terra, como estivesse na bíblia. O pastor lá, fazendo a cerimônia, mas as pessoas, os amigos, vão embora, os familiares vão de volta pra cerimônia que é pra os comes e 
bebes. Depois, o pessoal que trabalha no cemitério é que vai organizar, vão fechar a cova, eles não fecham enquanto os familiares, as pessoas estão lá. No comes e bebes, as pessoas fazem homenagens, cantam, fazem discursos, aí no caso dela, ela já era idosa, não aquela cerimônia triste, eu achei bonito parecia um filme, assim que você via todo mundo, como no seriado Lost. No final, todos se encontram, os parentes, os amigos, não é um momento de tristeza, parece um momento feliz que os familiares se reencontraram, se viram novamente. Esse funeral foi na cidade e nesse bairro que a gente morava, nesse cemitério tinha espaço, a maioria é cremado, mas, como ela já estava com 78 anos de idade, a família achou por bem que na geração dela não tinha essa tradição de cremar o corpo, por isso eles respeitaram a história dela e deixaram o corpo sem cremar, enterraram normalmente. Aí eles esperam seis meses pra fazer a pedra, até lá não fazem nada em cima da cova, onde enterra, deixa a terra baixar, compactar e aí depois que vão fazer, não sei se é cripta, uma pedrazinha bem bonita, vão fazer o nome dela, data de nascimento. $\mathrm{Na}$ cerimônia na igreja quando você entra, já recebe um papelzinho com um nome da pessoa, com as músicas e a foto dela também, não tem exposição de fotos. Um velório foi diferente do outro. Um deles a pessoa tinha morrido mias nova, e as pessoas já estavam mais tristes, a pessoa era mais jovem, os pais estavam lá, mãe já idosa presenciando o enterro do filho, aí já foi mais triste, ele morreu de derrame cerebral. Foi diferente por isso. Ah! eu esqueci de um detalhe também, que, no funeral da minha sogra, porque lá é sete dias pra enterrar, mas, assim que ela morreu, os parentes foram todos vê ela no leito que ela estava não tiraram o corpo rapidamente lá do local, vários estavam presenciando a hora da morte dela, estavam lá a quatro dias, tipo vigília, estavam lá o tempo todo, porque os médicos falavam, olha ela vai chegar a falecer, né. Inclusive na questão do governo de lá, você tem direito a duas semanas, quando um parente seu morre, né você recebendo, um direito seu pra você ficar com parente seu antes da morte dele e também depois pra acompanhar o velório o funeral depois pra preparar o funeral também; duas semanas somando tudo; a questão da morte e a questão do enterro, do funeral a parte burocrática toda, você como trabalhador quando um amigo, um parente seu morre você tem um dia de folga pra participar do enterro.

Os familiares põem o anúncio no jornal. Nos cumprimentos tem apertos de mão, abraços e palavras, mesmo que a pessoa não seja da família, a pessoa abraça os familiares. Esqueci de falar de um detalhe também do velório da minha sogra. Porque a família resolveu fazer uma, como vou dizer, no dia seguinte da morte dela, eles fizeram, assim um momento bem íntimo, só para os familiares mais próximos, os filhos, netos e noras e os irmãos que estavam ali, pra se despedir do corpo, detalhe porque na igreja o corpo não fica exposto, a família é que fecha o caixão. É opcional, muitas famílias não fazem, no caso da família dele eles resolveram fazer, pros netos se despedir antes de enterrar, isso foi durante uma meia hora. A funerária leva o corpo já preparado, lá mesmo eles costumam embalsamar o corpo, no caso deles eles congelam, eu achei estranho, porque estava bem duro o corpo, congelado, começou a suar, porque saiu do congelador. Foi num abrigo, na Noruega quando uma pessoa idosa adoece vai para um abrigo, aí dentro do próprio abrigo já tem uma mini capela, e os netos filhos podem colocar lembranças, desenhos, nesse caso eles colocaram flores, alguns netos tocaram no corpo dela, passaram a mão nela e acharam estranho porque estava congelado. Eu não vi se estava maquiado, não estava maquiado.

O funeral na ilha também foi de parente do meu esposo, uma tia dele que tinha falecido. Achei muito bonito, a igreja antiga, uma igreja velha. Tinha pessoas pra tocar, os músicos foram lá, no mesmo estilo, as pessoas recebem, o folheto com as músicas, a foto da pessoa, uma homenagem que eles fazem, mas muito bonito também. A ilha lá é muito bonita. Hoje, normalmente, as pessoas vão de preto, os homens vão de terno e gravata e as mulheres de vestido longo, nada muito curto, sapato preto, as crianças também usam roupinhas bonitinhas, se arrumam bem pro dia. Geralmente cumprimentam com "Meus pêsames", "Minhas condolências". Eles são diretos, usam a palavra morreu. Não, eu nunca ouvi, como no Brasil, assim expressões grosseiras, como "Fulano foi pro quinto dos infernos". 
$\mathrm{Eu}$ sou do norte do Brasil, Tocantins, inclusive, tem uma coisa interessante, alguns professores da universidade de lá que eles são do sul do Brasil, São Paulo, Rio. Uma coisa que eles acham estranho lá, no norte, é que normalmente as pessoas costumam ser fotografadas quando estão no caixão. Com minha mãe não foi assim, na minha infância, com meus avós, normalmente, as pessoas não tinham dinheiro para tirar fotos com a família, aí quando chegava a hora do enterro, que era a última oportunidade, chamava o fotógrafo, reunia todo mundo da família em volta do caixão e tirava a foto, o caixão no meio, tem foto com meus avós no caixão. É bem típico lá, no norte do Brasil. Hoje ainda existe, nós não tiramos, mas pessoas curiosas chegavam lá e tiravam fotos do caixão, com celular.

Aqui, no Brasil, é bem diferente porque a gente não tem tempo, é tudo muito corrido. No meu caso e dos meus irmãos, não teve tempo mesmo, foi mais uma questão do luto mesmo, de um dia foi mais uma questão de organizar. Quando ficamos sabendo da morte lá, no hospital, nem tivemos tempo de despedir do corpo lá, no hospital. Rapidamente, lá mesmo tiram a pessoa do leito, num saco plástico, levam não sei se foi pro necrotério ou coisa assim. A gente não chegou a ver o corpo nessa hora, nesse momento de despedida ainda, aí, a gente já foi organizando logo pra questão de cuidar do corpo, embalsamar, pra escolher o caixão, tudo na mesma hora; o funeral foi na casa, algumas pessoas já está velando o corpo na funerária, mas no caso da minha mãe o velório do corpo foi na casa. Aí liga pros parentes e vai todo mundo, lá na minha casa, dos meus pais tinha umas 200 pessoas que passaram e a casa fica aberta. Você põe uma plaquinha de enterro, do funeral na porta, abre as portas, o portão e as pessoas ficam na rua, os vizinhos todo mundo, entra e sai. Na plaquinha, está escrito "luto em família", dia e noite, tem até uma luz nela e ainda pergunta se quer que passe um carro de som pelas ruas avisando a cidade toda, achei que ficava demais o carro de som e não quis. O carro de som é da funerária, e eles oferecem, embalsamar o corpo, os tipos de caixão que você pode escolher, questão das luzes, velas se a família é católica ou se é protestante, aí, tem caixão com a cruz ou sem a cruz, e oferece água para as pessoas beberem e pão com manteiga no funeral. Flores é a família que tem de cuidar, acho que a funerária oferece flores de plástico, uma coroa de plástico de lá das flores, gente não quis foi de flores mesmo. Foi quase 24 h de velório, o corpo chegou ás $10 \mathrm{~h}$ e ficou até as $8 \mathrm{~h}$. Aí, chegam todas as famílias, inclusive, a maioria foi dormir lá, acho que tinha umas 30 pessoas que foram dormir lá essa noite, a casa é cheia de cômodos, cheia de redes, as pessoas dormem em rede, eu tive que sair procurando colchões, aí na polícia militar de lá eles têm colchões e ofereceram colchões lá pra gente. Acho que não emprestam pra todos, é que meus irmãos são militares, por isso, acho que já facilitou. Aí, eles chegaram lá pediram e eles entregaram; o caixão fícou aberto o tempo todo. O corpo ficou coberto até a metade, da cintura pra baixo com flores brancas de plástico. Quando era criança, as pessoas tiravam as flores do jardim, da rua e levavam e colocavam no corpo, hoje já mudou mais. A funerária fornece os suporte para o caixão e as cadeiras. Minha mãe morreu no hospital, e a funerária levou o corpo do hospital pra casa, no dia seguinte foram meus irmãos que levaram o caixão até o carro da funerária, e levamos o corpo até a igreja. Nós somos luteranos, mas os católicos fazem a mesma coisa por lá, levou pra igreja, fez uma cerimônia. Como lá, no Tocantins, é muito quente não demoramos muito, fizemos uma curta, chegamos na igreja às $8 \mathrm{~h}$ e antes das $9 \mathrm{~h}$ levamos o corpo para o cemitério. Na minha cidade, os políticos de lá não cuidaram de construir cemitério, já é o segundo cemitério e já está superlotado, não tem mais espaço para enterrar. Estão enterrando corpo em covas de pessoas enterrados como indigentes, uns sobre o outro porque não tem mais vagas. Como minha vó também estava enterrada, perguntei se minha mão poderia ficar junto, disseram que poderia. Aí, na hora do enterro, como brasileiro é bicho barraqueiro, escutei uma briga, vi que era meu pai, negando enterrar minha mãe lá na hora do enterro. Desde que eu era criança, eu e meus irmãos tínhamos o costume de enterrar na terra, e como passei muito tempo fora do Brasil, quando eu voltei, não sei se é moda ou questão de hierarquia social, que só pobre é enterrado na terra. Parece quando a pessoa tem um dinheiro melhor, poder aquisitivo melhor, você não enterra na terra, você coloca na gaveta, eu não sabia disso. Na minha infância, toda a gente não tinha costume de enterrar na 
gaveta. Meu pai negou enterrar minha mãe, e estava todo mundo lá, pastor, e ficou lá no sol quente com vidro aberto, o rosto dela pra fora e todo mundo foi acompanhando o coveiro pelo cemitério pra caçar outro lugar pra enterrar ela, uma gaveta disponível. Aí, acharam lá e enterraram numa gaveta disponível, e ainda começou a ter briga ainda, os parentes brigaram. Um queria uma coisa, outro queria outra, era discussão, era briga. Enterram e um parente ficou sem falar com outro. Minha mãe era católica, mas meu pai não quis batizar a gente, achava melhor deixar pra gente escolher quando crescesse, e me tornei luterana por acaso, por coincidência. Mas eles falaram em fazer um memorial, mas tem missa como os católicos. Meu pai fez visita de cova como eles chamam lá. Na Noruega, se não me engano, são dois dias na semana, a família escolhe, fim de semana sei que não enterra, não é todo dia não, acho que pode mudar de cidade para cidade. No enterro da minha, as expressões são "Meus pêsames", "Descansou", "Saiu dessa pra melhor". Meu nome é Hitaelane, brasileiro gosta de inventar nome, mas todo mundo me chama Hita, brasileiro também gosta de colocar apelido então me chamam de Hita.

No Brasil, as pessoas expõe mais, e não depende da idade, estou acostumada a ver corpos desde pequena, a gente sempre ia para os velórios. Na Noruega, é mais reservado, criança lá é mais protegida. Acho que o choro aqu, no Brasil, é mais desespero; na Noruega, é mais contido, talvez porque tem tempo pra preparar para o enterro. Aqui, no Brasil, acontece mais o inesperado, as pessoas morrem mais de acidente, morre mais de violência. Na Noruega, é bem menos o índice de violência, quando a pessoa morre já é o esperado, ou adoeceu, acontece de ter acidente, a morte lá é por velhice ou por doença que não teve cura, como é o caso do câncer. Essa semana mesmo, faleceu um primo e uma tia dele, tudo da mesma família. Foi puxado pra ele. Hoje estamos morando no Brasil, no Rio, e devemos ficar por uns 3 anos. Aqui no Rio tem uma igreja, que antigamente era a igreja dos marinheiros, na Noruega, sempre que tinha um lugar que tinha muitos marinheiros eles mandavam um capelão pra receber esses marinheiros, fazer casamento, quem tinha filho batizava, aí, hoje quase não tem mais marinheiros noruegueses, tem mais, no caso, aqui no Rio de pessoas trabalhando com petróleo. Aí, tem essa igreja aqui no Rio pra assistência pra esse povo. A tem os pastores, a Anne, inclusive, é uma delas. Tem o pastor Claúdio, aliás, eu e meu esposo somos os anfitriões da casa, eles têm uma casa aqui, a gente só cuida da casa, recebe convidados, organiza eventos, fica à disposição do pessoal. Aqui, ainda não providenciamos nenhum funeral, mas, se acontecer, estamos à disposição, inclusive, a Anne esteve aqui no Brasil quando teve aquele acidente com o avião da Air France que caiu no litoral do Brasil, no Recife. Tinha noruegueses que chegou a falecer nesse voo, os corpo apareceram, e, aí, a igreja teve um papel nesse momento muito forte, na hora do desespero, eles fizeram um memorial, se não me engano, aqui no Morro Dois Irmãos. A gente tem uma pedra lá com os nomes das pessoas que estavam desaparecidas. Os que foram encontrados, foram enterrados na Noruega. A Anne não tinha feito enterros, mas tinha feito muitos memoriais noruegueses.

\section{Informante 20 BR}

Eu moro aqui na Noruega há 5 anos. A gente não fala muito cidade, o nome é Raelingen. Tenho 41 anos e, assim que cheguei na Noruega, comecei a trabalhar com economia. Trabalhei 2 anos e meio no escritório de uma rede de hotéis. Trabalhei no departamento de economia. Depois eu parei, voltei pra escola e comecei a estudar somente o norueguês e, agora, nesse último ano, eu terminei e, agora, estou fazendo duas matérias que é o norueguês e o inglês acadêmico, porque, no próximo ano, eu vou voltar pra universidade pra fazer dois semestre que englobam todas as matérias relativas à contabilidade tributária da Noruega. Minha formação acadêmica é em Ciências Contábeis, e toda minha vida profissional foi em cima da área tributária no Brasil. Só que área tributária aqui é o oposto do Brasil. Então, vou ter esses dois semestre aqui no próximo ano, estou me preparando agora pra isso. Tenho experiência em funerais na Holanda. Aqui, eu não estive, eu 
não fui até o cemitério porque eu evito ao máximo essa situação, tá? Mas eu já fui ao funeral muito rapidamente aqui na Noruega.

A minha experiência, no Brasil, foi com uma parenta. Por exemplo, é que ela morreu num dia e, no dia seguinte, ela foi enterrada. Os parentes próximos, todos foram avisados, mas os parentes próximos que estiveram no local que foi assim uma surpresa muito grande, as pessoas estavam bem emocionadas, mas eu notei que as pessoas estavam se segurando muito, porque tinha a filha dessa parenta, tinha dezesseis anos nessa época, e eu acho que as pessoas estavam muito preocupadas com essa menina. Assim como aquela responsabilidade de você se controlar pra você não fragilizar mais ainda um adolescente. Então, isso foi muito claro naquela época também, eu percebi muito isso apesar de que eu vi a emoção estampada no rosto de todo mundo. Mas também, já tive uma outra experiência, no Brasil, de uma pessoa morrer num dia e ser enterrada em dois dias depois, porque estavam esperando parentes virem de outro estado. Também as pessoas estavam assim muito emocionadas, mas todo mundo controlado. E já aconteceram alguns enterros que eu fui de algumas pessoas e que eu notei que as pessoas se permitiam mais a questão da emoção, de pura emoção, não se sentir constrangida com o fato de estar muito emocionado, e ser aquela coisa de chorar, de soluçar, realmente, ter aquele momento de quase uma catarse, chegar num estado assim de começar a falar sozinha, e você vê que a pessoa tá um pouco descontrolada. Já aconteceu isso também. Foram experiências diferentes uma das outras.

Aqui, na Noruega, eu nunca tomei conhecimento, nessa pouquíssima vivência na questão do funeral. Não parecia que era funeral, não parecia. As pessoas, a questão da vestimenta. No Brasil a informalidade é total, e isso é inconcebível aqui, porque isso está muito ligado á questão do respeito e da tradição. Então, todo funeral, os homens se vestem de terno e gravata, e as mulheres de uma forma bem reservada e roupas bem sociais, aqueles vestidos com blazer, echarpes, sapatinhos, todo mundo bem arrumadinho, muito discreto. É um código, só que tem todo mundo muito bem-vestido no funeral. Aspecto número dois, você só percebe mesmo essa emoção mais assim, num filho, numa esposa. No caso, era primo do meu sogro; as pessoas só se permitem mais uma lágrima, um rosto vermelho, mas tem que tá muito próximo mesmo, uma ligação muito de dentro de casa, porque os outros familiares estão emocionados, estão tristes com a perda, mas o rosto não altera, praticamente não altera. Outra questão é que não sei se em todos, mas, nessa experiência, o caixão entrou como uma missa de corpo presente e dali seguiu pro enterro, e depois as pessoas passaram para uma sala ao lado e ali eles se confraternizaram. Houve café, chocolate, chá alguns croissants; as pessoas comiam, bebiam, conversavam durante um determinado tempo. Depois formou-se uma fila, a esposa e os filhos ficaram assim numa posição, e os parentes, as pessoas formaram uma fila, e todos foram lá dizer umas palavras de consolo, basicamente, é o que acontece. Eu só cheguei no momento de cumprimentar a família e me despedir de todos os amigos. Se tem anúncio no jornal da morte da pessoa?, Tem. A pessoa é enterrada, a família passa pra uma sala ao lado, tipo um salão mesmo, primeiro as pessoas tomam chá, café, conversam entre si. Depois de um determinado tempo, é que forma essa fila para as pessoas cumprimentarem e, aí, foi nesse momento que cheguei. Nos cumprimentos, basicamente, eles falavam "Meus sentimentos", "Se você precisar de alguma coisa, você entra em contato comigo, mas lembre-se que é vida que segue", "Isso faz parte do processo natural", eles não falam em Deus, a maior parte dos noruegueses, grande parte dos noruegueses são ateus. Então, essa questão de religião, aqui, na Noruega, é um assunto muito privado, muito. Não se fala essas coisas em público, eles não manifestam; até os que têm religião, que creem em algo, eles não se manifestam muito em público, e a gente aprende também, quando a gente faz o curso de integração, que religião, na Noruega, é um caso extremamente particular, você no ouve muito, tudo bem existe a questão do ateísmo que é muito grande, mas mesmo os que têm religião, pouquíssimos são os que falam: "Ah, foi a vontade de Deus". Eu nunca ouvi, assim, essas coisas por aqui, na Noruega, em conversas informais ou nesse momento. No curso de integração, falaram sobre funerais, porque, em determinado momento, eles começam a falar sobre os aspectos culturais dos imigrantes quevivem na Noruega, existem grupos específicos e que fizeram uma comparação com a Noruega. Por exemplo, tem 
muito imigrante aqui refugiado da guerra da Eritreia, então, no que a professora começou a falar no funeral que ela havia ido, essa coisa toda, os imigrantes da Eritreia começaram a descrever como era, e a gente ali vê, por exemplo, o funeral, na Eritreia, ele leva cinco dias, e a maior parte deles falou que as pessoas na Eritreia, as pessoas choram de gritar, e as pessoas querem se jogar em cima do caixão, que é muito natural isso acontecer, e que os outros membros da família ou os amigos têm que segurar a pessoa, porque acontece muito de as pessoas se jogarem, de chorarem, de gritarem e isso acontece assim um, dois, três, vários dias, e isso é completamente diferente daqui. A professora deu, não uma orientação, mas ela, de uma forma meio que delicada, recomendou reserva no nosso comportamento, porque isso assusta muito o norueguês, eles chegam a ficar com medo quando eles veem muito choro, choro descontrolado, um choro convulsivo, né? Eles ficam com medo, então, foi recomendado moderação na hora de se expressar emoções, porque as pessoas aqui são muito contidas, mas a professora, ela falou isso de uma forma muito suave. Nos cumprimentos, no momento que eu observei, eles dão a mão e, com a outa mão, eles não se beijam, eles encostam o rosto no rosto da pessoa, assim, uma expressão de sentimento, mas não existe beijo, isso de dois beijinhos que a gente tem, não existe. É só o cumprimento com a mão e você encosta o rosto no rosto da pessoa e, aí, você fala "Meus sentimento" ou alguma coisa assim. Esse é o abraço que nós costumamos dar. No momento da confraternização, não tem fotografia, a conversa entre eles é num tom bem baixinho, conversando entre eles, não existe música e, na igreja, eu não estive. Aqui a igreja é luterana. A maior parte deles é batizado, tem a confirmação que é a crisma, a igreja dos católicos, tudo acontece na igreja luterana, grande parte. Normalmente, o cemitério é do lado da igreja, quase sempre a igreja luterana tem o cemitério ao lado. E uma coisa interessante é que, por exemplo, eu moro num bairro que fica dentro da comuna de Raelingen. Então, toda comuna ela tem uma igreja central, não existe várias igrejas, só uma. Você paga imposto dentro dessa comuna, tudo da sua vida é dentro dessa comuna. Então, quando você morre, você vai ser enterrado dentro dessa igreja que é do Estado que é dessa comuna. Então, a pessoa nasce, cresce, morre tudo no mesmo lugar. É muito comum isso aqui. Não paga pelo enterro. Não, você paga pelo funeral, paga pela organização, da questão do salão, das flores, ornamentação, da questão da recepção, é um pacote. Você contrata uma firma, e essa firma resolve tudo, mas o enterro em si, você não paga. Já ouvi expressões grosseiras falando de morte, algo, mas não no enterro em si, mas já ouvi sim. Pessoas que não se agradavam daquele que estava sendo enterrado, só estão ali por consideração à esposa ou ao marido ou a algum parente direto. Estão ali mais pela questão da consideração, mas não pela pessoa e, de repente, num momento posterior a pessoa fala, “ Ah! Graças a Deus que saiu dessa e agora vai fazer festa lá, em cima, na casa do capeta, vai dar sossego aqui". Coisa assim desse tipo, né, desagradável, mas as pessoas falam; ou então "Fulano bateu as botas, mas também o que vocês esperavam, fumando duas carteiras de cigarro por dia? Estava semeando a própria morte". Desagradável, né, mas eu cheguei ouvir algumas vezes isso.

Eu tive um caso, eu tive um primo que ele sofreu um acidente e ele ficou alguns dias na UTI, e no momento que eu estava lá com minha mãe e o médico chegou pra dar a notícia, minha tia, a mãe desse meu primo, tinha ido em casa, então, a notícia foi dada diretamente a mim e a minha mãe. Normalmente, os médicos são muito delicados pra falar isso, e o que você falou é bem assim. "Fulano não resistiu aos ferimentos", acho que a maior, quando você está dentro de um ambiente de hospital, essa questão é muito profissional, os médicos são bem profissionais, eles suavizam usando esse termo: "Ele não resistiu aos ferimentos". Mas também, por exemplo, na perda da minha avó, ela ficou em coma durante muito tempo, e a enfermeira ligou pra avisou pra minha mãe. "Olha dona Nanci, sinto muito em lhe dar a notícia, mas dona Maria, acaba de falecer". É, eu acho que eu nunca vivenciei um momento assim, minha experiência, tá Fátima? Eu acho que eu nunca vivenciei um momento de assisti alguém dando uma notícia de forma rude, usando de expressões ou de palavras rudes, ou dando a notícia de forma muito abrupta, não. Eu acho que deve acontecer, com certeza, mas eu não vivenciei isso, graças a Deus. Olha, eu lembro que tinha uma empregada na minha casa, dona Solange, ela é evangélica; normalmente, já ouvi 
alguns amigos evangélicos abordando o tema, mas não contando o tipo de funeral, mas coisas assim que aconteceram com eles e eu já ouvi muito eles falando assim: "A pessoa tal agora está na Morada de Deus", "Agora está no Reino de Deus, não habita mais esse mundo aqui". Normalmente, pessoas muito religiosas usam desses termos; "Fulano habita na casa do Senhor", "Fulano não está mais entre nós mas está nos braços do Pai", coisas assim.

Eu sei que pode soar um pouco, assim, preconceituoso, mas como você está estudando essa questão e fala da cultura e tudo, eu só vou falar de uma coisa, de uma impressão minha, tá? Eu acho que essa questão de você expressar muita emoção, isso é muito, acho que isso está muito ligado à questão de base, de educação, de formação do indivíduo, então eu acho que menos educação formal, não estou falando de educação familiar não, estou falando de educação formal, quanto menos educação formal o indivíduo tem, o círculo social da pessoa, mais ele expressa de forma brutal, de menos controle, isso é aquela coisa, isso é muito, é bem expressiva mesmo, e quanto mais o indivíduo é mais polido, ele se emociona muito também, mas eu acho que, pelas minhas experiência, as pessoas tendem a ter um comportamento mais social. Pode ser um pouco de preconceito meu? Pode, mas acho isso, acho que é fruto de observações, mas é só isso.

\section{Informante 21 BR}

Bom dia. Eu sou Fulana, tenho 50 anos, sou professora, trabalho atualmente só na Rede Estadual. As experiências que eu tenho de velórios, funerais, de modo geral, não são muito diferentes de qualquer brasileiro. Considero que as pessoas comparecem a velórios mais por questões sociais, na verdade, do que afetivas. Eu tiro, assim, por mim e pela minha família nas ocasiões em que nós tivemos que fazer funerais dos nossos entes queridos. Se a gente pudesse não passar por aquilo, não fazer aquilo, não faria. Eu sou de família católica, praticante, então, nós realmente acreditamos que o corpo não tem nenhum valor. Pra nós, o valor de fé é o valor da alma. Então, aquele corpo ali não significa muita coisa. Não faria diferença se ficar ali mais tempo, menos tempo, se vai ser cremado, ou sepultado, né. Muito pelo contrário. Assim, nos parentes mais próximos nós optamos pela cremação, quando a pessoa manifestava esse desejo e tal. Então, em virtude desse distanciamento, que eu imagino que seja até uma espécie de autodefesa, né? A gente vai pelo social, claro, estamos preocupados, naquele momento, com as pessoas que ficaram, que estão sepultando o seu ente. As conversas acabam, muitas vezes, até destoando da situação. Em alguns momentos, eu estive pensando, recentemente, muito recentemente, a semana passada, estive num funeral. A gente quase que fica, assim, aguardando uma possibilidade de encontrar com pessoas que a gente sabe que vão estar ali e que a gente não vê há muito tempo e tem vontade, então, de conversar, de perguntar, de ... É uma oportunidade de encontro, né? E, aí, a conversa acaba sendo até destoante daquilo ali. De um modo geral, as pessoas chegam e dizem frases clichê do tipo "sinto muito", "meus sentimentos", ou, às vezes, até não dizem nada. Muitas vezes, o silêncio, ele é bastante mais eloquente do que propriamente as palavras que se diz, mas a gente tem que dizer alguma coisa, então, acaba optando por essas coisas clichê, "muita força". Se a gente sabe que a pessoa comunga da mesma fé que nós, a gente sempre fala alguma coisa em relação a essa fé, então, "que Deus conforte", "ele está melhor do que nós". Essas coisas desse tipo assim. Com relação a termos desagradáveis, eu não posso testemunhar esse tipo de acontecimento. O mais próximo disso de que eu lembro foi uma situação assim também. Eu estava em um funeral por razões sociais, questões, assim, de trabalho, que as pessoas precisavam estar. E, até pra descontrair daquela tensão, as pessoas começam a fazer algumas piadas, começam a fazer algum tipo de comentário, não sei se pra aliviar a tensão, pra fugir da realidade, e acabam falando umas coisas assim como "a viúva não vai sentir tanto assim". Esse tipo de coisa, mas nada grosseiro. Eu nunca presenciei nada grosseiro com relação às pessoas. Só lembro da literatura. Eu, provavelmente, talvez, tenha a minha memória contaminada mesmo da literatura, mas são 
bastantes as expressões: "já foi tarde", "ainda bem que morreu". E eu me lembro de uma ocasião em que eu assisti a um episódio da teledramaturgia, e que havia uma espécie de aula, de educação. Havia uma personagem que era professor na história e comentava com uma moça bastante simplória que veio dar a ele a notícia de que alguém da comunidade tinha morrido. Ela dizia assim "olha, dona fulana bateu as botas". Em contrapartida ele dizia "faleceu". E ela dizia assim "é, foi comer capim pela raiz", e ele, "entregou a alma ao Criador". "Abotoou o paletó de madeira", "passou desta para melhor". Coisas assim, ele sempre rebatendo. Ela dizia uma expressão popular desse tipo, e ele usava sempre um eufemismo. Aí, no final da cena, ela disse a ele: "Eu entendi, as pessoas que tinham respeito por ela vão falar como o senhor falou, e as pessoas que não gostavam dela falam como eu falei". Então, todas essas expressões como "comer capim pela raiz", "se encontrar com o diabo", "abraçar o capeta", "bater com o rabo na cerca" são de uso popular, mas eu nunca presenciei alguém usar.

Nos funerais e enterros, o comportamento dos familiares depende de duas coisas, fundamentalmente. Primeiro é uma questão de equilíbrio emocional, né? Evidentemente. E, depois, com relação ao nível sociocultural das pessoas. Uma vez, aconteceu uma coisa interessante. Estive num velório que não tinha defunto porque tinha um problema no trânsito. Foi lá no Cemitério do Caju, e o corpo não chegava da Santa Casa, ficou preso no trânsito. Por conta disso, como nós não tínhamos o nosso defunto, o nosso personal defunto pra velar, a gente ficou prestando atenção na capela em frente, onde estava sendo velado um bandido. E, aí, eu pude constatar uma série de coisas, inclusive, com relação á linguagem, a expressões que eu só conhecia metaforicamente, como, por exemplo, assim, a pessoa cair dura, ou se rasgar toda com relação a alguma situação. Eu vi, pela primeira vez, isso acontecer. Chegavam, no ônibus, trazidos... Segundo algumas pessoas que estavam do meu lado, isso é uma prática nas comunidades quando morre alguém importante, eles são obrigados a comparecer para velar o defunto. Era muita, muita gente chegando naqueles ônibus. Havia, como era de se esperar, mais de uma viúva. E, aí, eu constatei esta situação. Uma que chegou e começou a gritar e a chorar e, de repente, a criatura ficou assim toda rija, toda dura e caiu, feito um poste, desmaiada. Caiu dura literalmente, E, aí, depois, chegou uma outra e começou a se rasgar. Ela puxava, assim, a roupa, ela não disse que ia se rasgar, mas ela se rasgava e se jogava em cima do caixão, aquela coisa toda. Lá pelas tantas, a que tinha caído se recuperou e as duas saíram na bolacha. E, curiosamente, deu a hora de acabar o velório daquele bandido que tava lá. Eu, evidentemente, não segui o cortejo e não sei o que mais aconteceu. Quando chegou o corpo que nós íamos velar, já tava tudo fechado. Foi esquisito, nem houve velório, o caixão nem entrou na capela. O padre que estava lá encomendou o corpo rapidamente e dali já seguimos pra fazer o sepultamento. Quando nós saímos, já era noite, e quando passamos num dos bares que ficam na esquina do Caju, as duas viúvas, que tinham se atracado, estavam juntas, tomando cerveja. Então, já tava tudo bem, né? Evidentemente, no velório em que eu estava, ninguém deu esse tipo de espetáculo. As pessoas choram. Algumas choram mais do que outras. Há pessoas que são mais emotivas e tal, mas, de um modo geral, ninguém dá espetáculo. Choram porque é natural que chore mesmo, é de se esperar. O que não é natural, mas que, às vezes, acontece, é a pessoa não derramar uma lágrima, a pessoa ficar ali impassível, que a gente fica até preocupada com a pessoa que não está vivendo o seu luto. Mas o comportamento, eu acho que varia mesmo em função da classe social. As pessoas exacerbam tanto a coisa do social que, quando morre uma pessoa famosa, as pessoas tiram até selfies com o morto e colocam no Face. No velório da cantora Marlene, no Teatro João Caetano, houve uma espetacularização do funeral. Isso ocorreu também na morte do candidato à presidência, Eduardo Campos.

$\mathrm{O}$ abraçar é o mais comum no momento do cumprimento. Mesmo as pessoas que não têm hábito de abraçar. Quando você aperta a mão, guarda uma distância, fica um vazio que é, em geral, preenchido pelas palavras. Quando você não sabe muito o que vai dizer, corre logo pra abraçar, porque aquilo ali já cala no abraço.

Não é comum recepção, mas sei de caso extremo de pessoa que tinha hábito de, no aniversário de morte dos pais, fazer uma festa. A família Sendas, quando o Artur Sendas, de classe 
AAA, quando faleceu, após a missa de sétimo dia, houve uma festa de homenagem ao morto. No oposto disso, numa cidade do interior de Minas, Guarani, eu assisti, parcialmente, porque eu não era convidada, nem conhecia as pessoas de lá. Só cheguei perto porque me chamou a atenção. Assisti ao velório clássico do interior. De manhã cedinho passa um carro de som tocando músicas clássicas. Interessante porque eu já tinha assistido em outra cidadezinha do interior de Minas, e sempre são as mesmas composições Bachianas de Heitor Villa-Lobos. E dizem "A família de fulana de tal comunica o seu falecimento e informa que o corpo está sendo velado em sua casa, e o enterro será às tantas horas e convida todo mundo". Tem o tal do bolinho de chuva, o cafezinho, a cachacinha, tiram o chapéu, entram e cumprimentam os familiares. A casa fica com portas e janelas abertas. O falecido fica no caixão em cima da mesa da sala. Eu olhava de fora e via as pessoas servindo coisas em bandejas. Eu passava só na rua de um lado pro outro. Umas pessoas choravam um pouco mais alto, principalmente, na hora de fechar o caixão, mas outras a continham facilmente.

$\mathrm{Na}$ cidade grande, o serviço funeral oferece maquiagem. De um modo geral, eles incluem no pacote, principalmente quando a pessoa falece de doença, tem algum hematoma, ou alguma cicatriz. Acho que o fazem para amenizar a fisionomia, para os convidados não verem uma aparência tão diferente da que teve em vida. Perguntam também se os familiares querem que coloque algum colarzinho. Quando a pessoa era muito vaidosa, parte da família fazer a maquiagem porque sabe que ela nunca gostaria de aparecer publicamente sem pintura. No pacote básico, há flores dentro do caixão, contornando o corpo e uma coroa fora. Mas há famílias que não gostam que coloquem flores. Eu já vi famílias pedindo, quando avisaram da morte, para não levarem coroas de flores. Mas, aí, acho que foi por razão ecologicamente correta. Há também quem acuse os vendedores de flores de venderem coroas para uma família e, quando ela vai embora, pegarem as mesmas flores, trocarem a fita e venderem para outra família. Uma vez li, num obituário, "A família pede para não enviarem coroas".

Em geral, não tem havido nenhuma cerimônia religiosa no funeral. Apenas uma pessoa da pastoral que fica no cemitério se oferece para falar algumas palavras. Quando a família é muito religiosa, praticante, engajada numa igreja, há missa de corpo presente, às vezes, até com dois padres.

Cada vez menos há anúncios da morte no jornal. As pessoas cada vez menos leem o jornal físico. Elas optam por lerem as notícias na Internet e assistirem aos jornais pela TV. E esses anúncios são muito caros e têm pouca penetração. Poucas pessoas vão ler. As mídia verbais orais, são tão mais eficazes. Até mesmo a mídia escrita, você passa uma mensagem, escreve uma vez o texto e aperta sua caixa de distribuição e ela vai, em tempo real, prum monte de gente ao mesmo tempo. Agora, você tem outras formas de se comunicar com conhecidos, familiares e amigos.

De modo geral, os familiares fazem carinho no rosto do falecido, beijam a pessoa na testa, fazem carinho em suas mãos.

\subsection{Anexos B}

\section{E-mail 01 - Comunicando o falecimento - NO}

Caros Amigos,

O tempo é curto estes dias, mas isso é para dizer a triste notícia de que Helge morreu na sexta-feira. Ele caiu em seu quarto na casa de repouso e bateu com a cabeça contra uma borda afiada que causou uma fratura em seu pescoço. Muito dramático. Ele foi levado ao hospital, onde me juntei a ele, informou aos médicos que ele / não queríamos prolongar a vida do tratamento (membro de Morrer com Dignidade) apenas sedação e oxigênio, o que ele precisava. Seus filhos (filho e família que nós de férias na Espanha) e alguns netos vieram dizer seu adeus e às 6 da tarde ele foi retirado de oxigênio e morreu em paz. 
Foi um final brutal, não o que ele tinha planejado, mas o momento foi muito bom. Tivemos recentemente passamos uma semana maravilhosa na cabine, a sua última semana (em uma unidade fechada na casa) tinha sido muito bom. Eu tinha visitado e passei boas horas com ele todos os dias, seus filhos lhe tinha visitado nos dias anteriores e ele estava em um espírito muito bom.

Para aqueles de vocês que leem Norwegian eu colocar o anúncio em Aftenposten hoje. Helge tinha planejado seu funeral já há muito tempo e ele estará em seu espírito, sem a "interferência" religioso, com muita boa música e um encontro mais tarde com muito boa comida e vinho. O programa para o funeral vai conter muitas fotos e eu vou enviá-lo para você em uma ocasião posterior. Ele não queria que uma sepultura e suas cinzas serão espalhadas nas montanhas perto da cabine, em agosto.

É claro que é triste, mas mais "vemodig", que é uma palavra em norueguês Eu não tenho nenhuma tradução de, mas acima de tudo é bom, porque ele já não terá de suportar a vida em uma instituição e é só pegar mais e mais demente.

Eu tenho tantas e tantas boas lembranças após uma longa vida 36 anos com um homem muito divertido e maravilhoso. Seus filhos e netos são um grande apoio e passamos a maior parte do dia juntos desde sexta-feira.

Amor e calorosos votos a todos vocês. (sic)

Noruega

\section{E-mail 02 - Agradecimento - NO}

Dear All

Finalmente, algumas palavras para agradecer por suas calorosas e reconfortantes mensagens e manifestações de simpatia após a morte de Helge.

Tem sido um mês movimentado, cheio de emoções, e vai demorar algum tempo para entender que Helge se foi para sempre. O serviço funeral "humanista" foi muito bonito, com música maravilhosa, interpretada por «cousin-son» Georg Reiss (um músico famoso na Noruega e bem conhecido em Nova Orleans), no clarinete, e um organista brilhante (cego), sobre o piano. Os dois tocaram em nossa festa de casamento da pérola há cinco anos, e Helge tinha, há muito tempo, acordado com Georg que ele / eles deveriam tocar em seu funeral.

Os sete netos colocaram uma rosa vermelha sobre o caixão no início do funeral, e eu estou anexando uma foto que mostra o mais novo, Mikkel (11), colocando sua rosa. Você vai ver que a parede final da capela consiste em uma grande janela com vista para um jardim. Um pardal, no jardim, voou alegremente ao redor durante o funeral e voou para longe tão logo o funeral terminou! Sendo verão e conforme solicitado, as pessoas usavam "luz e roupas coloridas". Apesar de ser uma sexta-feira de julho, quando muitas pessoas estão longe, de férias, a capela estava cheia (mais de duzentas) e, depois, mais da metade chegou a um memorial almoço no nosso restaurante favorito, à beira-mar, com boa comida e vinho. Exatamente, como Helge queria.

Na semana passada, eu voltei para a nossa cabana na montanha com as filhas e irmã de Helge e espalhamos suas cinzas. Estou anexando duas fotos das montanhas; a primeira - de Helge tomada durante a semana, em junho, do lado de fora da cabine de um vizinho, e a segunda do lugar onde as cinzas foram espalhadas, perto de um "varde" - um monte de pedras, uma caminhada de dez minutos a partir da cabine e onde temos uma visão completa das montanhas Rondane. (sic)

Obrigada mais uma vez e os melhores desejos,

Noruega 


\title{
9. Apêndices
}

\section{Apêndice 01}

\author{
Pontifícia Universidade Católica do Rio de Janeiro (PUC-Rio) \\ Mestrado em Estudos da Linguagem \\ Orientadora: Rosa Marina de Brito Meyer \\ Coorientador: Ricardo Alencar \\ Aluna: Fátima Marinho Fabrício Monteiro
}

A entrevista é para coleta de dados que serão utilizados na pesquisa cujo tema é Ritual de Passagem Funeral. Para tanto, serão entrevistados 5 canadenses que tenham tido experiência desse evento no Canadá e no Brasil; 5 noruegueses que tenham tido essa experiência na Noruega e no Brasil; 5 brasileiros que tenham tido o mesmo tipo de experiência no Brasil e no Canadá; e 5 brasileiros que tenham tido o mesmo tipo de experiência no Brasil e na Noruega.

O informante, que não terá o nome divulgado, deverá fazer um relato minucioso das duas experiências, apontando se sentiu algum estranhamento no funeral no estrangeiro e o que lhe chamou mais atenção. Além de relatar toda a cerimônia em seu país, deve dizer quais são as expressões usadas para cumprimentar os familiares da pessoa falecida, como eles se comportam e que sentimentos expressam para os amigos.

Haverá três séries de entrevista. Esta, a primeira; daqui a uma semana, a segunda; e, de sete a dez dias depois, a terceira. Dessa forma, a compreensão do evento será aprofundada e ampliada.

Desde já, agradecemos pela contribuição.

Fátima Fabrício 


\section{Apêndice 02}

Quadro 13 - Segunda etapa das entrevistas

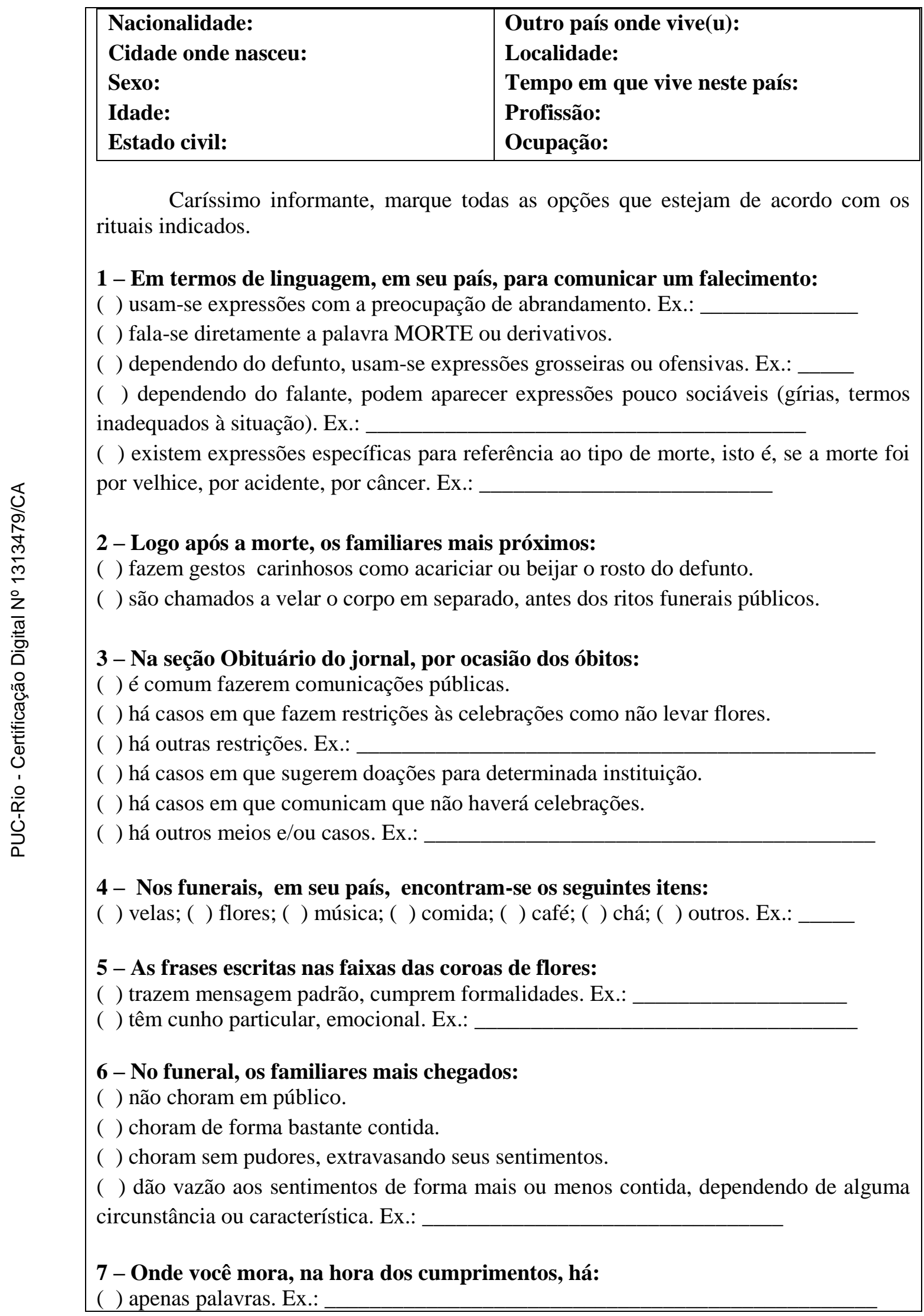


( ) palavras e gestos formais como aperto de mãos. Ex.:

( ) palavras e gestos afetuosos como abraço. Ex.:

( ) apenas abraço.

( ) outros. Ex.:

8 - Quando há a celebração da vida do ente querido, com comes e bebes, após o funeral ou o enterro, os lugares possíveis para esse evento são:

( ) a casa dos familiares ou de amigos; ( ) um espaço na casa funerária; ( ) um salão na igreja; ( ) um restaurante; ( ) uma casa de festas; ( ) um hotel de luxo; outros.

9 - São convidados a participar dessa cerimônia.

( ) apenas os familiares; ( ) familiares e amigos somente; ( ) familiares, amigos e demais convíveres sociais (vizinhos, colegas de trabalho); ( ) um religioso da religião do morto; ( ) todas as pessoas conhecidas do morto, independente do grau de intimidade.

10 - Nessa reunião festiva:

( ) as pessoas se vestem formalmente.

( ) algumas pessoas comparecem em trajes informais, dependendo do ambiente.

( ) algumas pessoas comparecem em trajes típicos regionais.

11 - Seu país, com o grande número de imigrantes que acolhe, mantém a tradição do ritual de passagem funeral e de celebração da vida.

( ) sim; ( ) não. Especifique:

12 - Em seu país, as diferenças entre funerais ocorrem por razões:

( ) econômicas; ( ) sociais; ( ) culturais; ( ) sazonais; ( ) outras. Ex:

13 - Quando ocorrem, essas diferenças afetam:

( ) a quantidade de itens; ( ) a qualidade dos itens; ( ) o tempo para o funeral; ( )o número de pessoas presentes; ( ) o lugar da cerimônia; ( ) outros. Ex.:

14 - Quanto à relação das pessoas com a morte, no seu país:

( ) após os familiares terem homenageado o ente querido, durante o funeral e/ou celebração da vida dele, passam a viver o presente, visando um futuro imediato.

( ) permanecem ligadas ao passado de forma ativa, reservando tempo do cotidiano para reverenciá-lo.

( ) costumam reagir mal, tornando as celebrações funerárias pesadas e difíceis.

( ) guardam as lembranças boas do morto e reagem positivamente após o período de luto.

( ) não conseguem superar com facilidade a perda e permanecem por muito tempo presas ao passado.

( ) há outros comportamentos. Ex.:

15 - Nos funerais da cultura estrangeira (Brasil/CanadáNoruega), alguma coisa o incomoda, choca ou impressiona.

( ) sim; ( ) não. Ex: 


\section{Apêndice 03}

Quadro 14 - Dados dos informantes

\begin{tabular}{|c|c|c|c|c|c|}
\hline Nacionalidade & $\begin{array}{c}\text { Cidade onde } \\
\text { reside } \\
\text { atualmente } \\
\text { ou cidade } \\
\text { natal }\end{array}$ & Sexo & Idade & Profissão & $\begin{array}{c}\text { Tempo/lugar } \\
\text { vivido no exterior }\end{array}$ \\
\hline $\begin{array}{l}\text { 1. Ucrano- } \\
\text { canadense }\end{array}$ & Edmonton & $\mathrm{F}$ & 59 & $\begin{array}{l}\text { Professora } \\
\text { universitária }\end{array}$ & 7 m - Rio de Janeiro \\
\hline 2. Canadense & Edmonton & $\mathrm{F}$ & 43 & $\begin{array}{l}\text { Professora do Ensino } \\
\text { Fundamental }\end{array}$ & $3 \mathrm{~m}$ - Rio de Janeiro \\
\hline 3. Canadense & Halifax & $\mathrm{M}$ & 50 & Garçom & $2 \mathrm{~m}$ - Rio de Janeiro \\
\hline 4. Canadense & Saskatchewan & $\mathrm{M}$ & 35 & $\begin{array}{l}\text { Economista - } \\
\text { Empresário }\end{array}$ & 1 a - Brasília/Anápolis \\
\hline 5. Canadense & Burlington & M & 29 & Advogado & $18 \mathrm{~m}$ - Rio de Janeiro \\
\hline 6. Norueguesa & Oslo & $\mathrm{F}$ & 48 & $\begin{array}{l}\text { Funcionária no Cons. } \\
\text { Geral da NO }\end{array}$ & 14 a - Rio de Janeiro \\
\hline 7. Norueguesa & Aalesund & $\mathrm{F}$ & 24 & $\begin{array}{l}\text { Professora de Inglês } \\
\text { e de Religião }\end{array}$ & $3 \mathrm{~m}$ - Rio de Janeiro \\
\hline 8. Norueguesa & Trondheim & $\mathrm{F}$ & 35 & $\begin{array}{l}\text { Urbanista e prof }{ }^{a} \text { de } \\
\text { capoeira }\end{array}$ & $\begin{array}{l}11 \mathrm{~m} \text { - Campo Grande- } \\
\text { MS }\end{array}$ \\
\hline 9. Norueguês & Bergen & M & 45 & $\begin{array}{l}\text { Assistente Social - } \\
\text { Família Anfitriã }\end{array}$ & 11 a -Tocantins e Rio \\
\hline 10. Norueguesa & Karmoy & $\mathrm{F}$ & 45 & Pastora & 8 a - Brasília e Búzios \\
\hline 11. Brasileira & \begin{tabular}{|l} 
São Luiz \\
Gonzaga - RS \\
\end{tabular} & M & 50 & $\begin{array}{l}\text { Professor } \\
\text { universitário }\end{array}$ & $\begin{array}{l}8 \text { a - CA - Alberta - } \\
\text { Edmonton }\end{array}$ \\
\hline 12. Brasileira & Canela & $\mathrm{M}$ & 51 & $\begin{array}{l}\text { Teólogo - Pastor } \\
\text { Luterano }\end{array}$ & $\begin{array}{l}10 \mathrm{a}-\mathrm{CA}-\mathrm{Alberta}- \\
\text { Calgary }\end{array}$ \\
\hline 13. Brasileira & Rio de Janeiro & $\mathrm{F}$ & 77 & $\begin{array}{l}\text { Professora de PLE, } \\
\text { tradutora, } \\
\text { escritora, poetisa }\end{array}$ & $\begin{array}{l}25 \text { a- CA -Alberta - } \\
\text { Edmonton }\end{array}$ \\
\hline 14. Brasileira & Goiás & $\mathrm{F}$ & 39 & $\begin{array}{l}\text { Formada em } \\
\text { Relações Intern. - } \\
\text { Chefe de equipe na } \\
\text { construção civil }\end{array}$ & $\begin{array}{l}5 \mathrm{a}-\mathrm{CA}-\mathrm{Alberta}- \\
\text { Edmonton }\end{array}$ \\
\hline 15. Brasileira & Rio de Janeiro & M & 49 & $\begin{array}{l}\text { Gerente de uma } \\
\text { empresa de } \\
\text { energia elétrica e gás }\end{array}$ & $\begin{array}{l}13 \text { a- CA - Alberta - } \\
\text { Calgary }\end{array}$ \\
\hline $\begin{array}{l}\text { 16. Brasilo- } \\
\text { norueguesa }\end{array}$ & Niterói & $\mathrm{F}$ & 59 & $\begin{array}{l}\text { Funcionária no Cons. } \\
\text { Geral da NO }\end{array}$ & 3 a- NO - Aalesund \\
\hline 17. Brasileira & Petrópolis - RJ & $\mathrm{F}$ & 62 & $\begin{array}{l}\text { Enfermeira, } \text { prof }^{\mathrm{a}} \text { de } \\
\text { enfermagem e } \\
\text { de norueguês, } \\
\text { tradutora } \\
\text { juramentada }\end{array}$ & $34 \mathrm{a}$ - NO - Aalesund \\
\hline $\begin{array}{l}\text { 18. Luso- } \\
\text { portuguesa }\end{array}$ & Rio de Janeiro & $\mathrm{M}$ & 49 & $\begin{array}{l}\text { Empresário, músico, } \\
\text { técnico de futebol }\end{array}$ & $4 \mathrm{a}$ - NO - Trondheim \\
\hline 19. Brasileira & Tocantins & $\mathrm{F}$ & 36 & $\begin{array}{l}\text { Pedagoga - } \\
\text { Administradora da } \\
\text { Igreja da Noruega no } \\
\text { Brasil } \\
\end{array}$ & 7 a - NO - Bergen \\
\hline 20. Brasileira & Rio de Janeiro & $\mathrm{F}$ & 42 & $\begin{array}{l}\text { Bacharel em Ciênc. } \\
\text { Cont. - Prof }{ }^{a} \text { de Mat. }\end{array}$ & 5 a- NO - Bergen - \\
\hline 21. Brasileira & Rio de Janeiro & $\mathrm{F}$ & 51 & Professora de Port. & Nunca morou fora. \\
\hline
\end{tabular}




\section{Apêndice 4}

Quadro 15 - Linguagens verbal e não verbal específicas

\begin{tabular}{|c|c|c|c|c|c|}
\hline Países & $\begin{array}{l}\text { Eufemismo } \\
\text { para o verbo } \\
\text { morrer }\end{array}$ & $\begin{array}{l}\text { Disfemismo } \\
\text { para o verbo } \\
\text { morrer }\end{array}$ & $\begin{array}{l}\text { Expressões } \\
\text { escritas nas } \\
\text { faixas }\end{array}$ & $\begin{array}{l}\text { Expressões de } \\
\text { cumprimentos }\end{array}$ & $\begin{array}{l}\text { Linguagem } \\
\text { não verbal }\end{array}$ \\
\hline Brasil & $\begin{array}{l}\text { Passar desta } \\
\text { para melhor } \\
\text { Viajar } \\
\text { Descansar } \\
\text { Ir para o céu } \\
\text { Ir morar com } \\
\text { Deus } \\
\text { Estar } \\
\text { desaparecido } \\
\text { Passar } \\
\text { Dormir como } \\
\text { um passarinho } \\
\text { Acontecer } \\
\text { uma } \\
\text { fatalidade } \\
\text { Fazer a } \\
\text { passagem } \\
\text { Falecer }\end{array}$ & $\begin{array}{l}\text { Ir para a terra } \\
\text { dos pés juntos } \\
\text { Comer capim } \\
\text { pela raiz } \\
\text { Bater as botas } \\
\text { Vestir o paletó } \\
\text { de madeira } \\
\text { Ir pra debaixo } \\
\text { da terra } \\
\text { Ir pro quinto } \\
\text { dos } \\
\text { infernos } \\
\text { Ir pro Inferno } \\
\text { Passar desta pra } \\
\text { pior } \\
\text { Abotoar o } \\
\text { paletó }\end{array}$ & $\begin{array}{l}\text { Descanse em } \\
\text { Paz } \\
\text { Homenagem } \\
\text { dos colegas de } \\
\text { tal lugar } \\
\text { Saudades } \\
\text { eternas de... }\end{array}$ & $\begin{array}{l}\text { Meus pêsames } \\
\text { Meus } \\
\text { sentimentos } \\
\text { Sinto muito } \\
\text { Seja forte } \\
\text { Lamento } \\
\text { Ele está bem ao } \\
\text { lado do Pai } \\
\text { Conte conosco }\end{array}$ & $\begin{array}{l}\text { Abraço forte } \\
\text { e silencioso } \\
\text { Beijo } \\
\text { Aperto de } \\
\text { mãos } \\
\text { Expressão } \\
\text { facial } \\
\text { Sorriso } \\
\text { Lágrimas } \\
\text { Olhos e nariz } \\
\text { vermelhos } \\
\text { Olhos } \\
\text { inchados }\end{array}$ \\
\hline Canadá & $\begin{array}{l}\text { Passar para } \\
\text { longe } \\
\text { Passed away } \\
\text { Falecer } \\
\text { Ir embora } \\
\text { Seu pai era } \\
\text { uma pessoa } \\
\text { fantástica } \\
\text { Ir para o outro } \\
\text { lado } \\
\text { Ir para um } \\
\text { lugar melhor } \\
\text { Acontecer um } \\
\text { acidente fatal } \\
\text { Sucumbir } \\
\text { Fezer a } \\
\text { passagem } \\
\text { Pelo menos } \\
\text { ele teve uma } \\
\text { vida boa } \\
\text { Ele teve uma } \\
\text { boa morte } \\
\text { Morrer } \\
\text { (quando a } \\
\text { morte já é } \\
\text { esperada) }\end{array}$ & $\begin{array}{l}\text { Chutar o balde } \\
\text { (bater as botas - } \\
\text { para pessoas } \\
\text { públicas) } \\
\text { Comprar a } \\
\text { fazenda } \\
\text { Game over }\end{array}$ & & $\begin{array}{l}\text { Minhas } \\
\text { condolências } \\
\text { Sinto muito (por } \\
\text { sua perda) } \\
\text { Vamos } \\
\text { encontrá-lo no } \\
\text { céu } \\
\text { Ele está em paz } \\
\text { Minha } \\
\text { simpatia } \\
\text { Minha mais } \\
\text { profunda } \\
\text { simpatia } \\
\text { Deus abençoe } \\
\text { você e sua } \\
\text { família } \\
\text { Que Deus dê } \\
\text { paz a seus } \\
\text { corações } \\
\text { Ele está em } \\
\text { um lugar } \\
\text { melhor } \\
\text { Seja forte, } \\
\text { minha querida } \\
\text { Que Deus } \\
\text { esteja com } \\
\text { você }\end{array}$ & $\begin{array}{l}\text { Abraço forte } \\
\text { e silencioso } \\
\text { Aperto de } \\
\text { mãos } \\
\text { Expressão } \\
\text { facial } \\
\text { Sorriso } \\
\text { Lágrimas } \\
\text { Olhos e nariz } \\
\text { vermelhos } \\
\text { Olhos } \\
\text { inchados }\end{array}$ \\
\hline
\end{tabular}




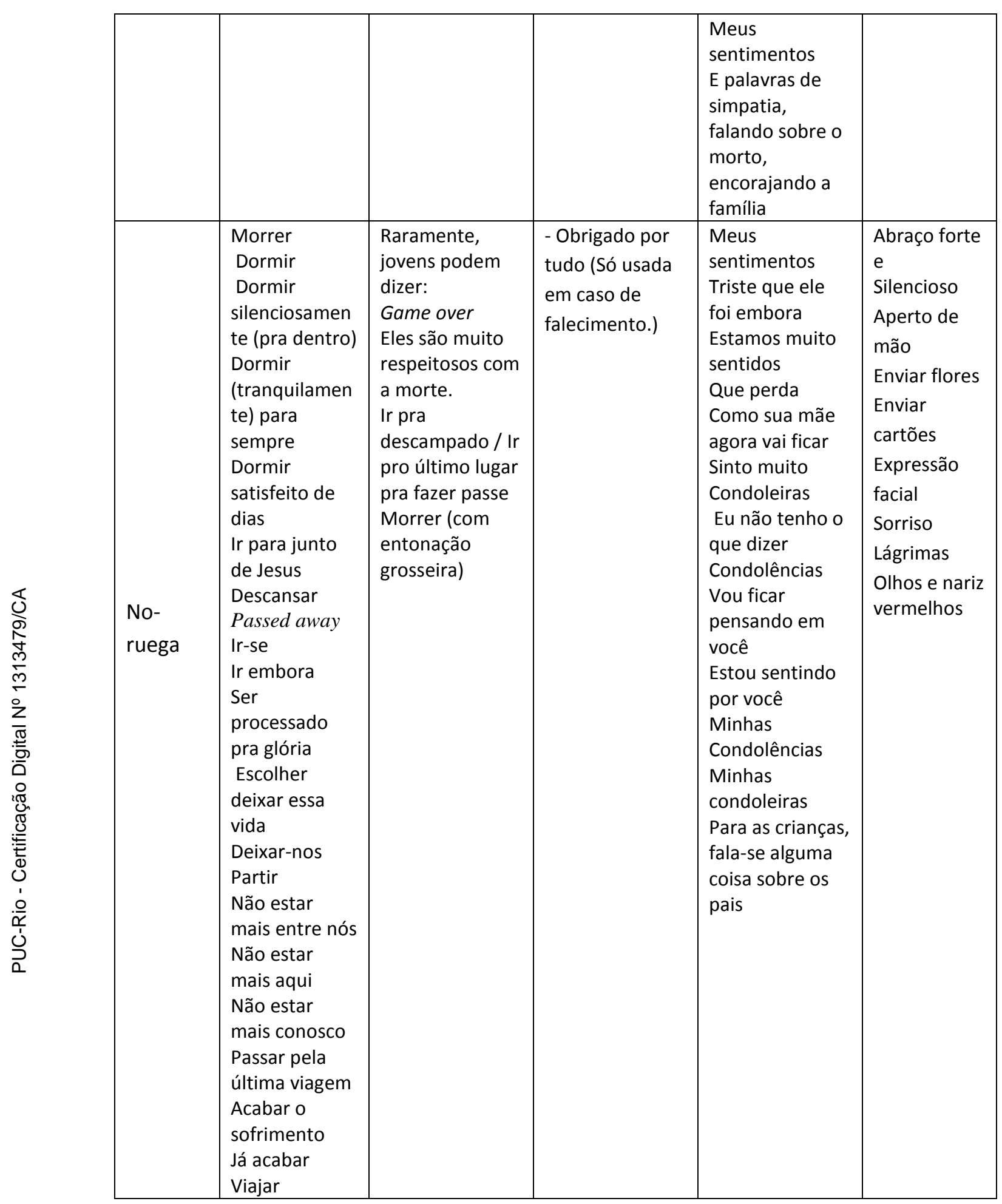

